PABLO ANTONIO LAGO

\title{
O CASAMENTO ENQUANTO CONCEITO INTERPRETATIVO E SEU RECONHECIMENTO COMO DIREITO MORAL DOS HOMOSSEXUAIS: DIÁLOGO CRÍTICO ENTRE AS CONCEPÇÕES DE JOHN FINNIS E RONALD DWORKIN
}

$$
\text { DISSERTAÇÃO DE MESTRADO }
$$

ORIENTADOR: PROFESSOR ASSOCIADO RONALDO PORTO MACEDO JUNIOR

FACULDADE DE DIREITO DA UNIVERSIDADE DE SÃO PAULO SÃO PAULO 


\title{
O CASAMENTO ENQUANTO CONCEITO INTERPRETATIVO E SEU RECONHECIMENTO COMO DIREITO MORAL DOS HOMOSSEXUAIS: DIÁLOGO CRÍTICO ENTRE AS CONCEPÇÕES DE JOHN FINNIS E RONALD DWORKIN
}

\author{
Dissertação de Mestrado apresentada ao Programa \\ de Pós-Graduação da Faculdade de Direito da \\ Universidade de São Paulo - Departamento de \\ Filosofia e Teoria Geral do Direito. \\ Orientador: Professor Associado Ronaldo Porto \\ Macedo Junior \\ Aluno: $\quad$ Pablo Antonio Lago \\ Número USP: 7538594
}

FACULDADE DE DIREITO DA UNIVERSIDADE DE SÃO PAULO SÃO PAULO 
Em memória de Jussara Regina Araujo.

Na condição de mãe exemplar,

foi aquela que me ensinou a ter orgulho daquilo que sou e alcancei, e a permanecer forte e perseverante na concretização de meus objetivos e ideais. 


\section{AGRADECIMENTOS}

Este trabalho foi realizado em um momento de efetiva transição. Não apenas em razão do fim da graduação e o imediato início das atividades do mestrado, com minha mudança de Curitiba para São Paulo, mas também pelas dúvidas e receios que tinha com relação à própria vida acadêmica. É por esta razão que sou extremamente grato ao meu orientador, Ronaldo Porto Macedo Junior, pela oportunidade concedida e pela confiança depositada. A ele devo os primeiros passos no estudo de autores e textos com grande complexidade filosófica, e a certeza de que é na pesquisa e no exercício da docência que dedicarei os próximos anos de minha vida. Suas argutas observações e críticas foram muito relevantes, e os méritos deste trabalho refletem diretamente seus méritos como orientador: sempre presente e atencioso, mas sem descurar da rigidez quando necessário.

Mas as razões que me trouxeram para esta grande metrópole refletem a atividade de outros professores que, em momentos anteriores, também me provocaram a buscar na pesquisa uma atividade recompensadora. Neste sentido, devo à professora Katya Kosicki não apenas a orientação na realização da monografia de conclusão de curso, durante a graduação, mas a preocupação e a presença marcante em minha trajetória acadêmica. A ela devo o "empurrão inicial" nos estudos de Filosofia e Teoria Geral do Direito, e em seu nome agradeço a todos os demais professores que, de uma forma ou de outra, permitiram que este trabalho fosse possível.

Agradeço ainda ao professor José Reinaldo de Lima Lopes, a quem devo o convite para participar do GEDS - Grupo de Estudos em Direito e Sexualidade da Faculdade de Direito da USP. Minha participação neste grupo foi fundamental para expandir meus horizontes sobre temas reconhecidamente difíceis, e sem ela o trabalho não teria atingido o nível de maturidade que acredito ter alcançado. A ele devo, ainda, inúmeras observações que constituem alguns dos argumentos centrais da dissertação.

Não posso me esquecer de dois colegas da pós: Leonardo Rosa e Horácio Neiva. Suas observações e apontamentos foram importantes em inúmeros momentos da elaboração deste trabalho. Com eles tive e tenho a felicidade de ter debates enriquecedores. Ao Leonardo Rosa devo, em particular, o primeiro acolhimento em São Paulo e o auxílio constante nas atividades de monitoria - assim como o apoio em várias matérias realizadas conjuntamente na pós-graduação. 
E nada seria possível sem os amigos. Agradeço a Thales Coimbra pelo apoio não apenas em questões acadêmicas, com as quais mantemos várias afinidades, mas em vários outros momentos de minha vida. Sua amizade sincera mantém-se inabalável, e sem dúvida alguma está entre as coisas mais preciosas que me aconteceram aqui em São Paulo. Em seu nome agradeço a todos os demais amigos, cada qual com suas peculiaridades, aqui ou no Paraná, que se mostraram sempre presentes em todos os momentos.

À Fundação de Amparo à Pesquisa do Estado de São Paulo - FAPESP - também manifesto meus sinceros agradecimentos pela bolsa concedida. Trata-se de instituição que se dedica, com seriedade, ao fomento das atividades de pesquisa em São Paulo. Fico honrado e agradecido pela oportunidade e por todo o auxílio prestado.

Por fim, e mais importante, devo agradecer ao meu pai, Antonio Lago. Sem ele nada seria possível. Na realidade, nada teria feito sentido sem sua presença e amor constante, em todos os momentos e dificuldades pelas quais passamos - particularmente neste ano de 2013. Sou grato por sua paciência, por seus sábios conselhos e pela preocupação, apoio e carinho insubstituíveis. Tenho dificuldades em expressar através de palavras toda a sua relevância em minha vida, pois elas nunca serão o bastante. Mas de algo tenho absoluta certeza: o orgulho que sinto por ser seu filho. 


\section{ÍNDICE}

RESUMO

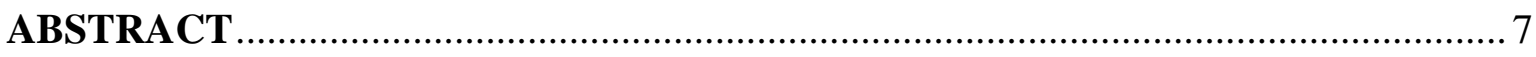

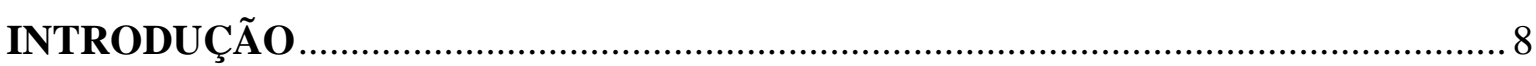

1. UMA CONCEPÇÃO DE CASAMENTO - A POSIÇÃO DE JOHN FINNIS .........21

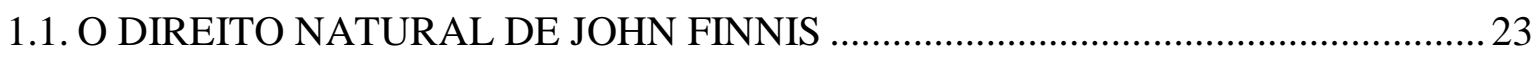

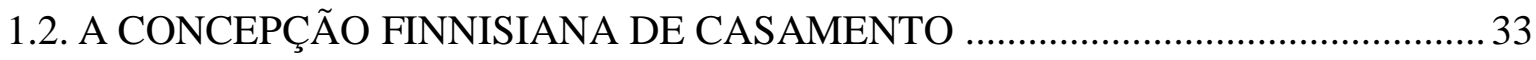

1.2.1. A ideia de união biológica e amizade entre os cônjuges ....................................... 35

1.2.2. Outras questões e implicações da posição finnisiana sobre o casamento - I ...... 41

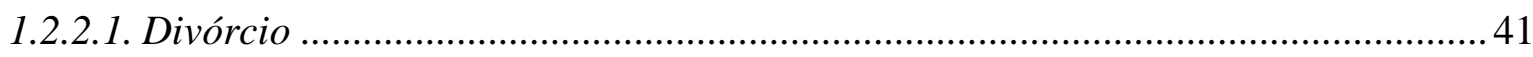

1.2.2.2. "União estável" e direitos para homossexuais? ........................................................ 46

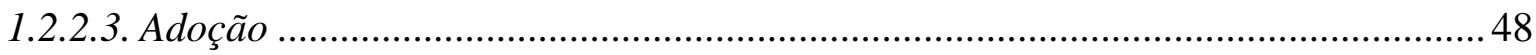

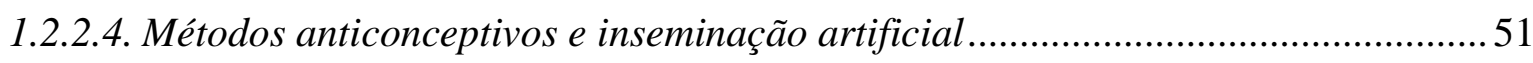

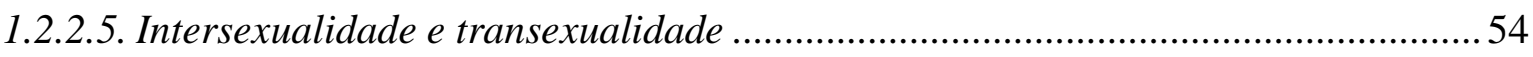

2. O CASAMENTO ENQUANTO CONCEITO INTERPRETATIVO - A POSIÇÃO

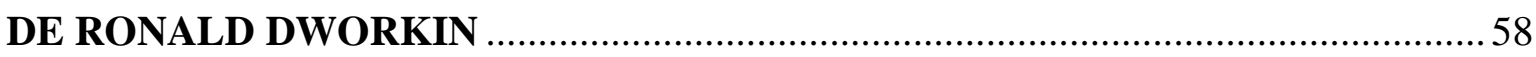

2.1. A DISTINÇÃO ENTRE CONCEITO E CONCEPÇÃO ............................................59

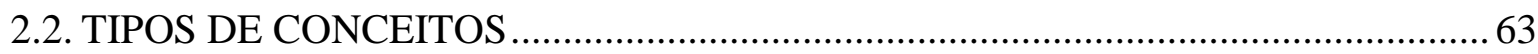

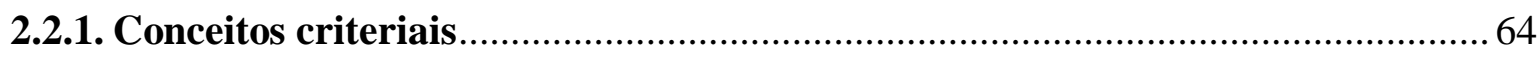

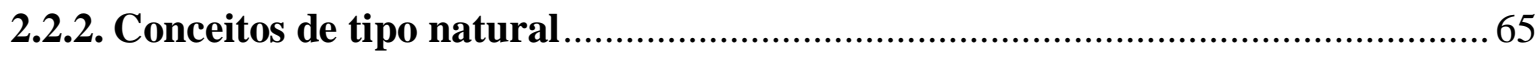

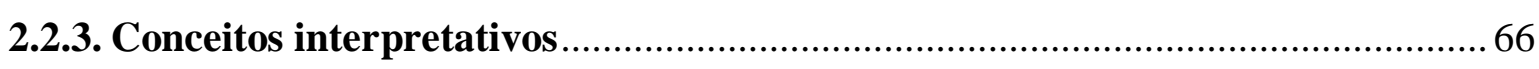

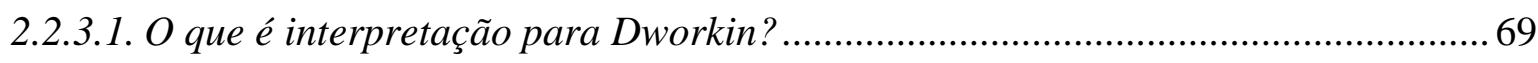

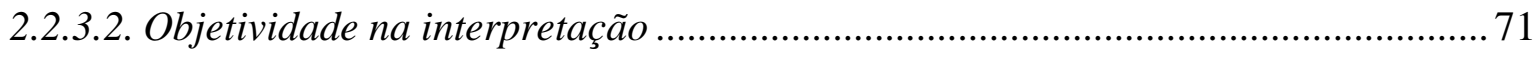

2.3. O CASAMENTO ENQUANTO CONCEITO INTERPRETATIVO ........................77

2.4. O QUE É VALIOSO? AS CONCEPÇÕES DE FINNIS E DWORKIN ...................... 79

2.4.1. Finnis versus Dworkin: qual teoria é metodologicamente mais adequada? ........ 84

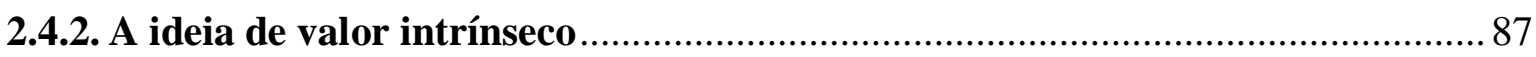

3. POR QUE FINNIS ESTÁ ERRADO? UMA CONCEPÇÃO ALTERNATIVA DO

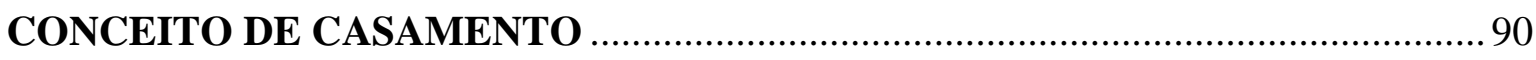

3.1. CRÍTICAS EXTERNAS À CONCEPÇÃO FINNISIANA DE CASAMENTO ..........91

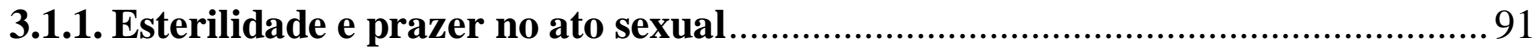

3.1.2. Há bens mais básicos que o casamento? Controvérsias e evidências do erro

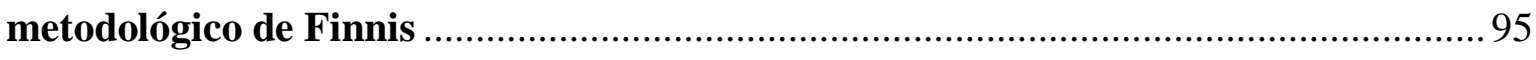


3.2. O PRIMEIRO PRINCÍPIO DA RAZÃO PRÁTICA, AS INCLINAÇÕES HUMANAS E A MANIFESTAÇÃO DA SEXUALIDADE COMO UM BEM.................................... 98

3.2.1. Outras questões e implicações da concepção finnisiana de casamento - II ...... 106

3.3. O QUE SERIA, ENTÃO, O CASAMENTO?......................................................... 109

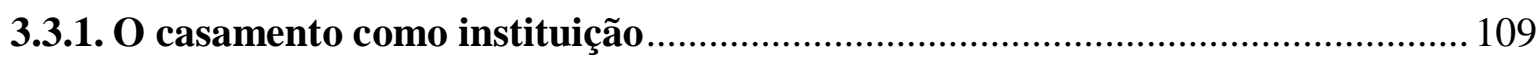

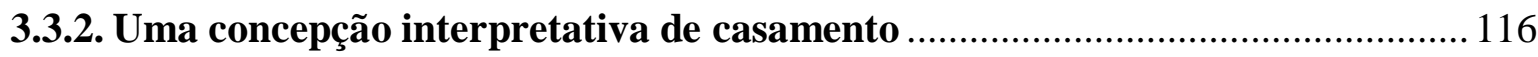

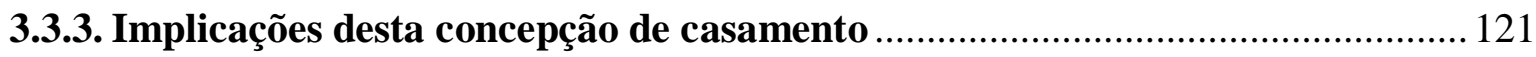

4. O CASAMENTO COMO DIREITO MORAL DOS HOMOSSEXUAIS ............. 124

4.1. AS RELAÇÕES ENTRE DIREITO E MORALIDADE - O DEBATE HART-

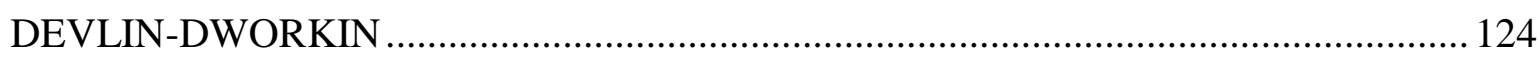

4.2. O DEVER DO ESTADO DE TRATAR A TODOS COM IGUALDADE DE

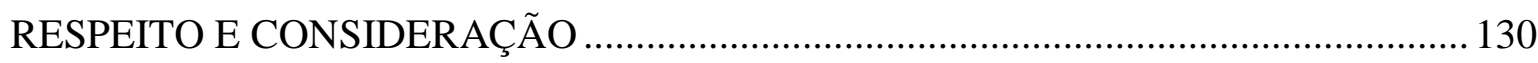

4.3. A RELEVÂNCIA DO PENSAMENTO CONCEITUAL E MORAL PARA A

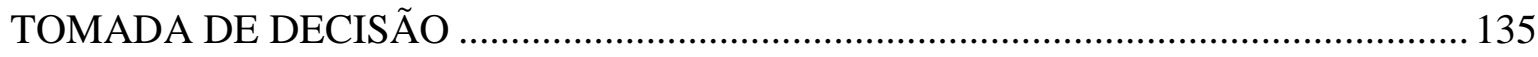

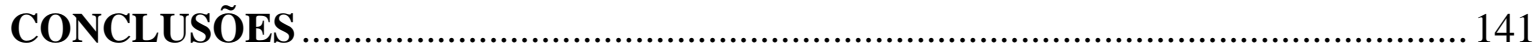

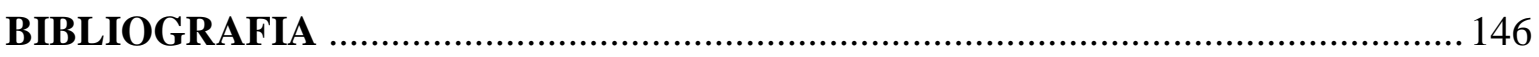




\section{RESUMO}

A presente dissertação de mestrado visa responder afirmativamente a seguinte questão: existe um direito moral ao casamento homossexual? Para tanto, analisa o tema a partir da Filosofia Moral e Política, o que demonstra a necessidade de se conceituar o casamento antes de verificar se este constitui ou não um direito moral. Parte-se das concepções de casamento formuladas por John Finnis e Ronald Dworkin, analisando-as criticamente, propondo-se após uma que seja capaz de tratar o casamento enquanto um conceito interpretativo. Somente então é possível verificar se o casamento corresponde a um direito moral dos homossexuais, o que se faz primordialmente a partir das críticas desenvolvidas por Herbert Hart e Dworkin à posição de Patrick Devlin, e da concepção dworkiniana de igualdade e dignidade humana. Conclui-se que o dever do Estado de tratar os indivíduos com igual respeito e consideração implica no reconhecimento do casamento como direito moral dos homossexuais, e que a análise da questão sob a ótica da moralidade pública implica na discussão de seus limites, bem como no debate mais amplo acerca dos direitos das minorias em geral.

Palavras-chave: conceito; casamento; direito moral; reconhecimento; homossexualidade 


\begin{abstract}
This dissertation aims to answer affirmatively the following question: is there a moral right to gay marriage? To do that, it analyzes the theme from the perspective of the Philosophy and Political Morals, which demonstrates the need to conceptualize marriage before checking whether it constitutes a moral right or not. It starts with the conceptions of marriage made by John Finnis and Ronald Dworkin, analyzing them critically, and after proposing the treatment of marriage as an interpretive concept. Only then it is possible to verify if marriage represents a moral right of homosexuals, which is made primarily from the critiques developed by Herbert Hart and Dworkin to the position of Patrick Devlin, and the dworkinian conception of equality and human dignity. It concludes that the state's duty to treat individuals with equal respect and consideration implies the recognition of marriage as a moral right of homosexuals, and that the analysis of the issue from the standpoint of public morality involves the discussion of its limits in the wider debate about the rights of minorities in general as well.
\end{abstract}

Keywords: concept; marriage; moral right; recognition; homosexuality 


\section{INTRODUÇÃO}

Questões sobre a correção moral do aborto, eutanásia e pena de morte são amplamente debatidas na sociedade. Por detrás de respostas que muitas vezes são apresentadas como "verdades irredutíveis" (e.g., a visão de um homem religioso de que o aborto constitui um atentado contra a vida e que consequentemente deve ser proibido) existe um complexo de impressões, opiniões e valores que encontram respaldo no ambiente social. Não é por outra razão que tais questões são analisadas de inúmeras maneiras, de modo amplo ou circunstancial, intentando respostas que sejam coerentes e convincentes. Tal fato ocorre porque existe um aspecto "normativo" em tais questões: indivíduos sustentam discursos de que a eutanásia, por exemplo, é certa ou errada. São questões relevantes não apenas pelo fato de gerarem divergências (as quais podemos observar diuturnamente), mas por, efetivamente, integrarem e alterarem substancialmente a vida de todos e por interagirem diretamente com os paradigmas que compartilhamos suprimindo e modificando os antigos, e criando novos. Logo, exercitar o raciocínio sobre tais questões significa compreender quais valores consideramos relevantes e se tais valores devem ou não ser mantidos diante de um mundo que se altera constantemente, com interações cada vez mais frequentes e complexas entre diferentes indivíduos e coletividades.

Creio que uma das questões deste gênero e que tem sido debatida com bastante interesse, particularmente no meio jurídico, refere-se ao casamento entre indivíduos do mesmo sexo. A pergunta central que este trabalho se dispõe a analisar pode ser resumida nos seguintes termos: existe um direito moral ao casamento homossexual ${ }^{1}$ Tais quais as outras questões mencionadas anteriormente, as visões favoráveis e contrárias ao casamento homossexual podem se assemelhar, em um primeiro momento, às "verdades irredutíveis". Pode-se afirmar, como muitos religiosos, que Deus criou "Adão e Eva" e não "Adão e Ivo", e que, consequentemente, não há que se falar em um direito ao casamento entre indivíduos do mesmo sexo. Por outro lado, muitos dos que sustentam a existência deste

\footnotetext{
${ }^{1}$ Particularmente, prefiro adotar a expressão "casamento homossexual" a "casamento gay". Observa-se que atualmente a expressão "gay" é mais utilizada para significar o homem homossexual, reservando-se o termo "lésbica" para a mulher homossexual. Neste sentido, "homossexual" poderia denotar tanto o homem quanto a mulher que possui uma orientação, condição ou inclinação sexual e/ou afetiva para pessoas do seu mesmo sexo (ou gênero). Todos estes termos são, em certa medida, controvertidos. O fato é que os movimentos que representam os interesses das minorias sexuais têm insistido nestas diferenciações, em particular para evitar eventuais conotações "negativas" (e.g., afirma-se que o prefixo "ismo" em "homossexualismo" tinha por função designar uma doença, de modo que o vocábulo considerado mais adequado atualmente é homossexualidade).
} 
direito afirmam que se trata de uma questão de igualdade e que, sendo análogos os relacionamentos entre heterossexuais e homossexuais, não se pode discriminar os diferentes tipos de relação afetiva - visões contrárias, neste sentido, se baseariam no preconceito.

Posições semelhantes às apresentadas são muitas vezes "documentadas" e é fácil encontrá-las através da Internet. Em inúmeros sites de notícias, quando se vincula algum acontecimento relacionado à homossexualidade, existem campos onde o leitor pode manifestar sua opinião. Em uma maioria significativa dos casos as opiniões apresentadas assemelham-se a verdadeiros dogmas: seja por acreditarem piamente que suas opiniões são "verdadeiras", ou mesmo por falta de espaço para digitação, o fato é que as visões expressadas pelos leitores não são efetivamente justificadas. Pelo contrário, podem até tomar por base premissas que já foram cientificamente consideradas incorretas.

Tomemos como exemplo a afirmação de que a homossexualidade é contrária à natureza, o que se contrapõe a muitas pesquisas no campo da Biologia, notadamente a constatação de que outros animais (e não apenas os seres humanos) podem assumir comportamentos de natureza homossexual ${ }^{2}$. Se não bastasse, as principais organizações mundiais de saúde deixaram de considerar a homossexualidade uma doença a partir dos anos 70 (e.g., a decisão pioneira da Associação Americana de Psiquiatria em 1973², que inviabiliza - de um ponto de vista científico - o argumento de que a homossexualidade constitui uma "doença" e que pode ser "curada"). Consequentemente, a ausência de fundamentos científicos sólidos a embasar os argumentos de muitos dos que são contrários ao casamento homossexual, no Brasil, faz com que grande parte de seus discursos repouse apenas em dogmas religiosos.

De qualquer sorte, o debate também encontra espaço nos círculos acadêmicos. Neste âmbito, para serem considerados relevantes, os argumentos apresentados devem ser

\footnotetext{
${ }^{2} \mathrm{O}$ biólogo americano Bruce Bagemihl constatou que em mais de 450 espécies de animais, notadamente mamíferos e aves, foram identificados em maior ou menor grau hábitos homossexuais. Entre os exemplos documentados pelo referido biólogo em seu livro Biological Exuberance: animal homosexuality and natural diversity, de 1999, está o dos macacos bonobos. Uma interessante análise da questão e da metodologia adotada para chegar a estas conclusões pode ser encontrada na reportagem de Denis Russo Burgierman, da edição de dezembro de 2006 da revista Super Interessante. Disponível em <http://super.abril.com.br/ciencia/atracao-iguais-446781.shtml>. Acesso em: 15 fev. 2012.

${ }^{3}$ É interessante mencionar que a Associação Americana de Psiquiatria (American Psychiatric Association APA) também se manifestou favoravelmente ao casamento entre homossexuais - conforme se verifica no Resource Document on Same Sex Marriage, do Committee on Gay, Lesbian and Bisexual Issues, disponível em <http://www.psych.org/lib_archives/archives/200417.pdf>. Acesso em: 23 dez. 2011. A decisão oficial da Associação Americana de Psiquiatria pode ser conferida em: <http://www.psych.org/Departments/EDU/Library/APAOfficialDocumentsandRelated/PositionStatements/1 97310.aspx>. Acesso em: 23 dez. 2011.
} 
racionalmente fundamentados e coerentes. Portanto, constitui uma preocupação premente desta dissertação, enquanto projeto acadêmico, defender justificadamente a coerência $e$ validade da posição que será adotada.

Antecipo que defenderei a existência de um direito moral ao casamento homossexual. Mas o foco e o método utilizado para justificar esta posição são distintos dos que, atualmente, tem ocupado a mente de inúmeros juristas. O que se observa no Brasil é que o casamento entre indivíduos do mesmo sexo tornou-se um tópico de Direito Constitucional. Confere-se especial atenção às recentes decisões acerca do que se compreende como "união homoafetiva", como no caso das demandas que culminaram com a decisão do Supremo Tribunal Federal, proferida em maio de 2011 na ADI nº 4277 e na ADPF $n^{\circ}$. 132, reconhecendo a aplicação do regime jurídico da união estável aos casais homossexuais.

Os argumentos apresentados por juristas que se debruçam sobre o tema são dos mais variados, indo da hermenêutica constitucional até questões políticas referentes à separação dos poderes. Pode-se sustentar que a intenção do constituinte foi garantir que o casamento só pudesse ocorrer entre homem e mulher, de modo que a decisão do Supremo Tribunal Federal, no caso mencionado, extrapola os limites constitucionais de sua atuação. Dessa maneira, estaríamos diante de uma interpretação contra legem e de uma incompatível atividade legiferante pelo Judiciário. Posição interessante, neste sentido, é a de Ives Gandra da Silva Martins, que em seu artigo Família é aquela que perpetua a sociedade (MARTINS, 2011) sustenta que a ideia constitucional de família está intimamente ligada à capacidade de gerar prole.

Por outro lado, pode-se afirmar que a interpretação utilizada pelo Supremo Tribunal privilegiou a sistematicidade constitucional. Uma leitura intencional e literal dos dispositivos constitucionais seria incompatível com o princípio da igualdade, também contemplado na Constituição, o que nos levaria a uma situação de incoerência. E, em se tratando de interpretação do próprio texto constitucional, não há que se falar em atuação legiferante do Tribunal, mas sim na aplicação de dispositivos pré-existentes cujo sentido só pode ser alcançado através da atividade interpretativa. Se não bastasse, como afirma Maria Berenice Dias (2009, p. 146), "Nem a Constituição nem a lei, ao tratarem do casamento, fazem qualquer referência ao sexo dos nubentes. Portanto, não há qualquer impedimento, quer constitucional, quer legal, para o casamento entre pessoas do mesmo sexo”.

Certamente, o estudo do casamento homossexual no Brasil não se esgota nos argumentos apresentados. O fato é que tais argumentos possuem suas próprias 
complexidades e, por si só, são capazes de gerar inúmeras dissertações e teses. Todavia, neste trabalho não pretendo analisá-los diretamente, fazendo-o apenas e na medida em que se relacionam diretamente com a metodologia proposta.

A questão central deste trabalho não é afirmar que os homossexuais possuem direitos civis ou constitucionais, mas sim que existe um direito moral ao casamento entre pessoas do mesmo sexo. Isso significa que é necessário analisar, primordialmente, o que se entende por casamento para somente após demonstrar que este corresponde a um direito moral dos homossexuais. Tal questão tem particular relevância na medida em que diversos grupos pelos direitos dos homossexuais entendem que o reconhecimento da união estável homoafetiva, apesar de ter representado um avanço do ponto de vista de suas aspirações, ainda não atende completamente a demanda pelo reconhecimento do casamento. Em outras palavras, para estes grupos a união estável foi um passo importante, mas não se confunde nem substitui totalmente a demanda pelo reconhecimento do casamento entre indivíduos do mesmo sexo. Logo, o foco do trabalho não está em questões eminentemente jurídicas, de exegese constitucional, ou políticas, como a mencionada separação dos poderes. Ao contrário, encontra seus alicerces na Filosofia Moral, na análise conceitual e nas relações entre Direito e moralidade pública.

Como se pode perceber, valho-me de uma distinção entre direito moral e direito legal (ou jurídico em sentido estrito). A ideia aqui é a de que o direito moral relaciona-se diretamente com valores morais, no sentido de que a defesa do casamento como um direito dos homossexuais é uma questão de justiça - por uma série de motivos que serão tratados ao longo do trabalho, é justo que homossexuais possam se casar. Diversamente, ao se tratar o casamento como um direito legal, o que se pretende é verificar a possibilidade de, em um determinado sistema jurídico positivado, acolher-se uma concepção de casamento que englobe pessoas do mesmo sexo ${ }^{4}$. Deve-se atentar, entretanto, para o fato de que a ausência de clareza na determinação de um direito legal ao casamento homossexual no caso

\footnotetext{
${ }^{4}$ A distinção entre direitos morais e direitos legais ou jurídicos pode ser apreendida da análise da teoria de Ronald Dworkin. Em sua obra Justice for Hedgehogs (DWORKIN, 2011), Dworkin concede especial atenção à ideia de "direitos políticos", os quais são vistos como "trunfos" diante das demais justificativas para a ação política do Estado (DWORKIN, 2011, p. 329). Tais direitos políticos se assemelhariam aos direitos morais na medida em que correspondem aos interesses particulares que consideramos relevantes (por questões de equidade e justiça), e que devem ser protegidos mesmo diante de políticas que seriam capazes de melhorar a vida em sociedade como um todo (DWORKIN, 2011, p. 329). Os direitos legais, por sua vez, podem ser paradigmaticamente exemplificados como aqueles direitos criados por um corpo legislativo, que podem ser executados pelos indivíduos através de instituições adjudicantes como os tribunais (DWORKIN, 2011, p. 331). Em qualquer caso, entretanto, o que se pretende é demonstrar a relação intrínseca entre o Direito e a moralidade, na medida em que a comunidade política não possuiria um "poder moral" de criar ou executar obrigações contra seus membros a menos que os trate com igual consideração e respeito (DWORKIN, 2011, p. 330), como será visto no último capítulo deste trabalho.
} 
brasileiro (i.e., as inúmeras divergências teóricas sobre sua existência ou não na perspectiva constitucional), torna especialmente relevante a análise do casamento enquanto um direito moral, fortalecendo os argumentos favoráveis ao reconhecimento deste direito enquanto um direito dos homossexuais - repercutindo na esfera propriamente jurídica, do Direito positivado. É clara, portanto, a existência de controvérsias que a dissertação buscará explicitar e dirimir.

Assim, um dos méritos do trabalho está na tentativa de suprir esta lacuna no debate jurídico nacional: a inexistência de um debate que tenha por foco o conceito de casamento, com o devido rigor e aprofundamento filosófico. Afinal, se for da "essência" do casamento, por exemplo, a diferença de gêneros, a convicção de que o casamento constitui um "direito dos homossexuais", ainda que em atenção ao princípio da igualdade, transforma-se em um nonsense. Ainda que exista uma união entre pessoas do mesmo sexo, seja ela juridicamente reconhecida ou não, esta união não seria um "casamento" em razão dos caracteres distintivos que o constituem.

Entretanto, trata-se apenas de uma questão terminológica ou taxonômica? Qual a diferença entre considerar o casamento como um direito dos homossexuais, e criar uma espécie de "união civil" com os mesmos direitos e deveres que o matrimônio para casais do mesmo sexo? Tais perguntas relacionam-se diretamente com o tema em questão e revelam sua importância. Afinal, se não houver alguma característica especial no conceito de "casamento" e tudo se resumir às perspectivas de natureza material da união (e.g., questões sucessórias e de natureza previdenciária), admiti-lo como um direito dos homossexuais transforma-se em uma questão secundária e sem relevância prática.

Mas antes de tudo associam-se às questões levantadas as motivações que tornaram o matrimônio um dos objetivos buscados pelos movimentos LGBT. O que levou o casamento a entrar na pauta de discussões morais da atualidade? De onde veio este interesse em se debater algo que parecia corresponder a um "instituto natural" e que permaneceu indiscutível ao longo de tantos séculos? E, notadamente, quais fatores levaram lésbicas e gays a lutarem pelo direito de se casar? Estas são interessantíssimas questões de cunho histórico e, ainda que de forma breve, merecem um tratamento específico - ou, ao menos, um direcionamento ao leitor que delas se interessar.

George Chauncey é um dos historiadores que se debruçou sobre estes questionamentos. Em seu livro Why marriage? The history shaping today's debate over gay equality (2005), Chauncey analisa as razões que levaram lésbicas e gays a lutarem pelo casamento nos Estados Unidos. Ainda que existam inúmeros pontos de distinção entre os 
contextos, acredito que muitas das suas observações sobre o movimento homossexual americano encontram reflexos no caso brasileiro. Como sugerem Peter Fry e Edward MacRae no livro $O$ que é homossexualidade (1985), para compreendermos a organização do movimento homossexual no Brasil devemos atentar para a história global deste movimento, que remonta à Europa do século XIX ${ }^{5}$.

Certamente, não pretendo fazer um longo excurso histórico sobre a formação do movimento homossexual, pois fugiria da especificidade do presente trabalho ${ }^{6}$. De qualquer modo, o ponto levantado por Chauncey e que atraiu fortemente minha atenção está na relação que ele argumenta ter ocorrido entre o movimento homossexual e os movimentos feminista e negro dos anos 60/70 ${ }^{7}$.

Se em um primeiro momento o movimento homossexual americano preocupou-se em incluir lésbicas e gays na sociedade e em combater a cada vez mais intrusiva ação

\footnotetext{
${ }^{5}$ Em suas palavras, "Como o Brasil não é uma ilha, mas sim parte da economia mundial (o FMI que o diga), é claro que, ao discutir as ideias e práticas que surgem nos centros de produção de conhecimentos e que são veiculadas pelos órgãos de comunicação de massa, não podemos ignorar o fluxo de informação e ideias que passa pela alfândega brasileira. Assim, ao discutir a organização e ideias do movimento homossexual no Brasil, teremos de levar em consideração a história deste movimento desde suas origens na Europa no século XIX" (FRY; MACRAE, 1985, p. 13/14).

${ }^{6}$ Uma obra de grande valia que trata destas questões é Elementi di critica omosessuale, de autoria de Mario Mieli (2002). Referido autor sugere que, na realidade, o que observamos é uma nova ou segunda onda do movimento homossexual. A primeira teria se originado na Alemanha entre o final do século XIX e começo do século XX, em decorrência das pesquisas de Karl Heinrich Ulrichs sobre sexualidade e da criação do Comitê Científico Humanitário em Berlim, fundado e dirigido por Magnus Hirschfeld. Esta organização tinha como principal atividade a campanha pela revogação do parágrafo 175 do Código Penal alemão, que criminalizava as relações homossexuais entre homens, e também deu origem a uma Liga Mundial pela Reforma Sexual, organizando inúmeras conferências ao redor do mundo sobre o tema da emancipação homossexual. Entretanto, a vitória do nazismo em 1933 implicou no recrudescimento da perseguição aos homossexuais, marcado pelos campos de concentração e a identificação de lésbicas e gays com o triângulo rosa (MIELI, 2002, p. 84/86). A memória deste primeiro movimento homossexual só é retomada no pósguerra, em particular com as pesquisas realizadas pelo Gay Liberation Front americano ao longo dos anos 60/70, dando origem a uma segunda onda do movimento de liberação homossexual (MIELI, 2002, p. 15).

${ }^{7}$ É importante ressaltar que o movimento homossexual, ao menos nos Estados Unidos, está associado diretamente ao crescimento da hostilidade "anti-gay" do pós-guerra, como assevera George Chauncey (2005). Para referido autor, o aumento de visibilidade das "subculturas gays" entre o final do século XIX e início do século XX era visto por muitas pessoas como apenas mais um sinal da crescente complexidade e liberdade de uma cultura metropolitana burguesa. Neste meio tempo, parte da hostilidade contra homossexuais foi alimentada pela dificuldade com que muitos homens absorviam as dramáticas mudanças nos papéis de gênero, decorrentes da sociedade industrial e das conquistas do movimento feminista. Assim, a literatura médica conservadora americana acerca da homossexualidade seria marcada pela ideia de "inversão sexual", que antes de abarcar interesses sexuais específicos, argumentava que a homossexualidade (seja masculina ou feminina) corresponderia a uma "violação dos papéis convencionais de gênero". Para Chauncey, esta hostilidade ganhou força a partir de 1930, em razão da depressão econômica que precipitou uma crise nas relações de família e gênero. A partir daí, homossexuais eram vistos como depravados morais que, assim como os comunistas, representavam um perigo para a integridade nacional: "Thus, lesbians and gay men were increasingly denounced as cosmopolitan outsiders whose loyalties were not to the nation but to an international or extranational community of people like themselves. Some congressmen and magazines claimed they constituted a 'Homintern' (a term playing on the Comintern, or Communist International), which controlled Broadway, Hollywood, and other media, and used their immense cultural power to undermine American values" (CHAUNCEY, 2005).
} 
estatal contra a homossexualidade, notadamente as sanções às suas práticas (i.e., as leis que criminalizavam a "sodomia", e as inúmeras batidas policiais em bares, saunas e clubes gays $)^{9}$, posteriormente decidiu quebrar com sua retórica assimilacionista ${ }^{10}$ em favor da afirmação, celebração e cultivação das diferenças homossexuais, inspirado na crescente insistência do movimento negro de que "o negro é belo" (black is beautiful), derivando-se daí o "gay é bom" (gay is good). A crescente influência das críticas do movimento feminista aos papéis de gênero também influenciaram o movimento homossexual, fornecendo um amplo suporte para a crítica à superioridade heterossexual ${ }^{11}$ (CHAUNCEY, 2005). Mas se a luta assimilacionista foi deixada de lado pelo movimento homossexual, quais fatores o motivaram a lutar pelo direito ao casamento, uma das instituições mais conservadoras que existem?

George Chauncey chama a atenção para três pontos relevantes que, a partir da década de 1980, levaram lésbicas e gays à busca do reconhecimento de suas uniões. O primeiro diz respeito à crescente visibilidade e busca por aceitação pelos homossexuais. Deste modo, se a afirmação de uma "cultura gay" propiciou a "saída do armário" de inúmeras pessoas, ao mesmo tempo culminou com a busca por parte destas pessoas pelo respeito em vários segmentos sociais. E, por consequência, a visão social passou a mudar: a maioria significativa das pessoas passou a conhecer alguma lésbica e gay, e muitos

\footnotetext{
${ }^{8}$ Sodomia não se confunde com homossexualidade. Somente em tempos relativamente recentes que os termos passaram a se confundir. Originalmente, sodomia significava qualquer ato sexual que não fosse procriativo. Neste sentido, afirma George Chauncey (2004, p. 514/515): “In colonial America, regulation of nonprocreative sexual practices - regulation that carried harsh penalties but was rarely enforced-stemmed from Christian religious teachings and reflected the need for procreative sex to increase the population. Colonial sexual regulation included such nonprocreative acts as masturbation, and sodomy laws applied equally to male-male, male-female, and human-animal sexual activity. 'Sodomy' was not the equivalent of 'homosexual conduct' (...) Sodomy laws that exclusively targeted same-sex couples, such as the statute enacted in 1973 in Texas, were a development of the last third of the twentieth century and reflect this historically unprecedented concern to classify and penalize homosexuals as a subordinate class of citizens".

9 "Most gay people conducted themselves according to the terms of an unofficial and unacknowledge moral accord with their families and the authorities, which led them to feel relatively (but never entirely) secure so long as they did nothing to draw attention to themselves (...) So long as gay people remained 'discreet' and didn't tell people they were gay, most of their fellow workers and straight friends did not care to ask. Some gay people found it stressful to live a double life and difficult to keep their gay and straight social worlds separate, but given the draconian news laws of the postwar period, they simply had no choice (...) Much of the earliest gay organizing was motivated by the perception that the state had violated the terms of this unwritten accord through its increasingly intrusive surveillance and policing of gay life" (CHAUNCEY, 2005).

10 "(...) like the leaders of many minority and ethnic groups in the 1950s, the nascent gay movement embraced a largely assimilationist platform by stressing their allegiance to the nation, their desire to integrate the homosexual into the larger society, their conformity with all American social conventions save the one that distinguished them, and their desire to restrain the public behavior of the other homosexuals who did not share their assimilationist intentions" (CHAUNCEY, 2005).

11 "The growing influence of the feminist critique of sex roles and the concrete achievements of the women's movement nonetheless provided an important impetus to the development of both lesbian and gay politics and provided a wider base of support for their critique of heterosexual superiority" (CHAUNCEY, 2005).
} 
faziam parte de seu convívio próximo como parentes, amigos queridos ou competentes colegas de trabalho (CHAUNCEY, 2005). Mas são os outros dois pontos que impulsionaram com grande força a busca pelo direito ao casamento.

O pandemia do HIV/AIDS representou, notadamente para os homens gays, a necessidade de se unirem contra uma doença que, em seus primórdios, era ignorada pelas autoridades estatais e que correspondia a uma verdadeira sentença de morte para os infectados. Se não bastasse, o fato de ser considerada por muitos como uma "doença gay" fez com que vários indivíduos, se à época não eram assumidos, fossem literalmente jogados para fora do armário, enfrentando em muitos casos a reação negativa de seus familiares. Rejeitados pelos próprios pais e demais parentes, competia ao eventual companheiro ou aos amigos mais próximos o cuidado com o enfermo, o que aproximou os homossexuais e criou vários grupos de voluntários diante da ausência do Estado. Ocorre que a falta de um vínculo conjugal ou familiar impedia que o soropositivo, na hipótese de internação, recebesse as visitas de seu eventual companheiro. E, se não bastasse, tal companheiro também tinha seus direitos sucessórios questionados judicialmente (em geral com êxito) pelos familiares do homossexual no advento da morte, caso houvesse algum testamento elaborado em seu favor, assim como não possuía qualquer direito de natureza previdenciária. Este verdadeiro drama em que se viram empurrados inúmeros gays fez com que estes atentassem para a necessidade de ter os mesmos direitos já assegurados aos casais heterossexuais, que no caso americano não incluía apenas direitos de ordem previdenciária ou sucessória, mas também a própria visitação e permanência em hospitais na condição de acompanhante. Sendo tais direitos assegurados em razão do vínculo matrimonial, o direito ao casamento transformou-se em um dos principais elementos da luta homossexual (CHAUNCEY, 2005).

O outro ponto importante atingiu notadamente as lésbicas e foi conhecido como o "lesbian baby boom”. A integração da luta lésbica com os movimentos feministas ganhou fôlego com a "revolução sexual" que marcou a segunda metade do século XX. A pílula anticoncepcional garantia à mulher a palavra final sobre gerar ou não uma criança, mas foram os avanços decorrentes da fertilização artificial que cultivaram em muitas lésbicas a busca pela maternidade sem necessidade de manter um vínculo com algum homem. Desta forma, inúmeros casais de lésbicas recorriam a bancos específicos ou a algum amigo próximo (em geral gay) para que cedesse seu sêmen e, assim, propiciasse a inseminação artificial. Ocorreu uma verdadeira "explosão de bebês" (baby boom) criados por casais de lésbicas, mas o problema é que o vínculo de filiação era garantido apenas à responsável 
pela gestação - a "mãe biológica". Consequentemente, na hipótese de falecimento da mãe biológica, a companheira supérstite tinha que recorrer ao Judiciário para garantir a guarda da criança, que também a considerava como mãe. Mas tais demandas eram contestadas em geral pelos avós (pais da falecida) e até mesmo pelo Poder Público, que argumentava agir pelo bem da criança. A impossibilidade de constarem duas mães nos registros da criança, ou mesmo a de adoção conjunta, fez com que muitas lésbicas encontrassem no direito ao casamento uma resposta eficaz para os problemas que estavam enfrentando (CHAUNCEY, $2005)^{12}$.

Mas estes dois grandes acontecimentos (o HIV e o baby boom) não são o bastante para responder à questão anteriormente formulada - por que não uma "união civil" ao invés do casamento? Afinal, o que estes acontecimentos trouxeram ao mundo LGBT foi justamente a necessidade de direitos que garantissem uma segurança material aos homossexuais. Se todos os direitos fossem garantidos por algum instituto distinto (no caso brasileiro, com as devidas cautelas, pode-se afirmar que o são pela "união estável"), a luta pelo matrimônio corresponderia a uma mera questão taxonômica.

A chave para esta questão poderá ser encontrada ao longo deste trabalho. Em um primeiro momento, uma análise conceitual do casamento preocupar-se-á também em verificar as suas finalidades. Em síntese, sustentarei que se casar corresponde a uma prática social que tem um fim que não é apenas de ordem material, mas também imaterial, moral. Logo, a própria ideia de casamento envolve uma perspectiva que transcende os direitos e deveres que com ele possuem uma ligação direta. Acompanhando Ronald Dworkin (2006a, p. 86; 2006b, p, 9/10, p. 153), defendo que para apreendermos o sentido de uma prática social como o casamento devemos analisá-lo de modo interpretativo - o que implica dizer, dworkinianamente, que a ideia que temos de casamento (nossa concepção) deve ser formulada em relação direta com os valores que este conceito busca apreender e concretizar, ajustando-a adequadamente (fit) e de forma coerente às demais práticas paradigmáticas que compartilhamos socialmente. Logo, não se trata de mera

\footnotetext{
${ }^{12}$ Em síntese, a luta pelo casamento por parte de lésbicas e gays pode ser resumida nos seguintes termos: "Three developments in the 1980s increased the interest of lesbians and gay men in seeking legal recognition for their relationships. We've already chronicled the first: the dramatic growth in the visibility and acceptance of lesbian and gay men in some parts of the country and some segments of society (...) More important, however, were two searing experiences of the 1980s that forever impressed on lesbians and gay men the importance of securing their relationships: the devastating impact of AIDS and the astonishingly rapid appearance of what everyone soon called the lesbian baby boom. Neither development represents a 'maturation' in the movement or in the individuals involved. But they resulted in the community's sudden, mass experience of two key stages in the life cycle that exert special pressure on any relationship: parenthood and death" (CHAUNCEY, 2005).
} 
questão taxonômica ou criterial, o que significaria dizer que o sentido de casamento poderia ser apreendido através do estudo da maneira pela qual os indivíduos empregam o temo ou o utilizam em razão de finalidades pré-determinadas - ideias que Dworkin aborda no primeiro capítulo de sua obra Is Democracy Posible Here? (2006a), e que serão analisadas adiante.

Mas não pretendo iniciar este trabalho elaborando uma concepção de casamento que busque compreendê-lo de maneira interpretativa. Se tenho a convicção de que lésbicas e gays possuem direito ao casamento, acredito que a melhor forma de desenvolver meu raciocínio é, justamente, partindo do entendimento contrário - das posições que negam às minorias sexuais tal direito. Assim, pretendo desenvolver este trabalho na forma de um “debate argumentativo", razão pela qual o primeiro capítulo tem por alvo a análise de uma concepção de casamento que não abrange casais homossexuais - na realidade, trata-se de uma concepção que refuta terminantemente a possibilidade de casamento entre indivíduos do mesmo sexo.

A concepção de casamento que pretendo analisar criticamente foi elaborada por John Finnis. Referido filósofo moral e jurista está entre os principais expoentes na atual agenda de debates em Filosofia e Teoria Geral do Direito, notadamente pelo seu empreendimento teórico que analisa o fenômeno jurídico nos moldes de uma "teoria analítica de Direito Natural”. Creio ser fundamental compreender o que vem a ser o Direito Natural para Finnis antes de abordar sua concepção de casamento, razão pela qual o primeiro capítulo desta dissertação irá abranger também considerações gerais sobre sua teoria e pontos fundamentais de seu pensamento - notadamente o que (e quais) são os "valores e bens humanos básicos" e sua relação com o que denomina serem os "requisitos básicos da razoabilidade prática".

É interessante ressaltar que não escolhi Finnis apenas por predileção pessoal. De fato, acredito que sua teoria do Direito é particularmente interessante e bem construída, e tais pontos se refletem em sua posição acerca do conceito de casamento. E se, para Finnis, o casamento corresponde apenas à união duradoura e amigável entre um homem e uma mulher, os quais podem se "unir biologicamente", gerando ou não filhos ${ }^{13}$, resta claro que sua concepção de matrimônio implica na exclusão conceitual da ideia de casamento homossexual - o que torna particularmente interessante a análise crítica de sua posição. Se não bastasse, dentre as inúmeras posições contrárias ao casamento entre pessoas do mesmo

\footnotetext{
${ }^{13}$ Sua concepção de casamento é tratada em diversos artigos, dentre os quais destaco Marriage: a basic and exigent good (FINNIS, 2008).
} 
sexo, a posição de Finnis é a que apresenta maior rigor analítico e conceitual, buscando razões para justificar suas convicções ${ }^{14}$.

Posteriormente, analisarei elementos centrais da teoria dworkiniana. Ronald Dworkin, assim como Finnis, ocupa um espaço central nos debates acerca de Teoria do Direito e Filosofia Moral, Política e Jurídica - sendo sua obra reconhecida e debatida também no contexto nacional. As inúmeras distinções de que se vale em suas teorizações, como a existente entre conceitos e concepções, mais a forma com que concebe os conceitos (criteriais, de tipo natural, interpretativos), sua ideia de interpretação, objetividade, dentre outros, é particularmente útil para a construção de uma concepção de casamento. De fato, Dworkin trata o casamento enquanto um conceito interpretativo, o que considero ser a melhor forma de auferir seu sentido. Acredito que uma concepção de matizes dworkinianos sobre o matrimônio é superior, particularmente do ponto de vista metodológico, pois é capaz de responder satisfatoriamente à existência de controvérsias teóricas. Isso significa dizer que ao expandirmos nossa compreensão sobre determinado conceito socialmente compartilhado somos capazes de notar a existência de diferentes concepções que buscam se ajustar, de modo coerente, às diferentes práticas que regem a vida social. Quando dada concepção de um conceito é cega à realidade das práticas sociais (quando, portanto, não está “ajustada de forma coerente"), ela se torna insatisfatória e incapaz de oferecer uma resposta adequada às críticas contidas em concepções divergentes. Pretendo analisar tais questões no segundo capítulo desta dissertação ${ }^{15}$.

No terceiro capítulo, apresentarei primeiramente críticas à posição finnisiana. Sustentarei, essencialmente, que Finnis está equivocado ao conceber o casamento como um bem humano básico. Apoiando-me na leitura que Germain Grisez faz sobre o primeiro princípio da razão prática, exposto por São Tomás de Aquino, sustentarei que sexualidade

\footnotetext{
${ }^{14}$ Não estou sozinho neste entendimento. Dentre os possíveis argumentos "conservadores" que podem ser levantados contra a homossexualidade (e o casamento entre pessoas do mesmo sexo), Stephen Macedo ressalta a "longa tradição" do Direito Natural nas teorizações acerca da moralidade sexual. Neste sentido, afirma em seu artigo Homosexuality and the conservative mind (1995): "If an account of the immorality of homosexual acts as such is to be found, one might reasonably expect to find it articulated by those who carry on the long tradition of natural law theorizing about sexual morality" (MACEDO, 1995, p. 6). Esta também é a posição de Andrew Koppelman, que analisa as posições jusnaturalistas acerca do casamento em seu artigo Is marriage inherently heterosexual? (1997): "This paper will examine the most sophisticated version of the claim that marriage is necessarily heterosexual, that developed by the 'new natural law theorists,' Germain Grisez, John Finnis, Gerard V. Bradley, and Robert P. George. As Stephen Macedo has observer, the argument developed by these writers 'is by far the most elaborate intellectual case for distinguishing between homosexual and heterosexual activity'”' (KOPPELMAN, 1997, p. 2).

${ }_{15}$ Brevemente, o argumento que pretendo desenvolver e que demonstra a superioridade metodológica da posição dworkiniana diz respeito ao equívoco da posição finnisiana. Acredito que Finnis acaba por assumir uma postura "essencialista", uma vez que o seu modo de conceber o casamento (enquanto bem humano básico) assume contornos dogmáticos. Em outras palavras, se o casamento é evidentemente o que Finnis diz que ele é, como explicar a existência de tanta controvérsia sobre este conceito?
} 
e suas formas de manifestação (sejam heterossexuais ou homossexuais) são inclinações humanas básicas, e portanto um bem mais fundamental e evidente que a ideia de união biológica que fundamenta sua concepção de casamento. A parentalidade, o vínculo entre mãe, pai e filho, também é um valor básico que independe da ideia de casamento para sua existência (ninguém deixa de ser pai ou mãe por não ser casado). Estes pontos são revelados pela própria experiência que temos com a vida humana, de modo que o erro de Finnis assemelha-se a um erro de natureza factual - sua incapacidade de perceber que as inclinações humanas são muito mais amplas e complexas do que ele imagina.

Em síntese, o erro de Finnis é tratar o casamento como um bem humano básico, sem atentar satisfatoriamente para sua perspectiva institucional. Na segunda parte do terceiro capítulo explicarei o que significa uma instituição, tomando por base as lições de John Searle. Apresentarei as razões que fazem com que o casamento corresponda a uma instituição e também abordarei a sua finalidade, diretamente dependente da nossa capacidade de criarmos vínculos intersubjetivos (notadamente de natureza afetiva) - o que entendo corresponder tanto a uma inclinação humana, quanto a um valor intrínseco. Aqui também ficará clara a importância da teoria dworkiniana, pois ressaltarei que o casamento tem um point valorativo cujo sentido só pode ser apreendido interpretativamente. Em síntese, meu argumento é de que o casamento corresponde a uma prática social valiosa, na medida em que é a uma instituição que objetiva proteger, através da criação de direitos e deveres, expectativas criadas mutuamente, em geral decorrentes do compartilhamento de uma vida afetiva e solidária com outra pessoa - inexistindo razões conceituais para a exclusão de indivíduos homossexuais do matrimônio.

Minha análise estará centrada, como já mencionado, no estudo conceitual do casamento, o que não elide minha preocupação com o reconhecimento do matrimônio como um direito moral dos homossexuais. Logo, o quarto e último capítulo desta dissertação possui um objeto distinto e, ainda que de forma não exaustiva, estará centrada na relação entre moralidade pública e Direito. A possibilidade de que, conceitualmente, seja possível falar em casamento homossexual não possui relação direta com o fato de que muitas pessoas consideram a homossexualidade imoral. Neste sentido, quando podemos falar que determinadas condutas ou "estilos de vida" são imorais? Até que ponto o Direito pode (ou deve) levar em consideração a visão dos indivíduos que consideram determinadas condutas como condutas imorais? Qual seria, por exemplo, a relevância do fato de que a homossexualidade é considerada imoral pela maior parte da população? Como este fato se relacionaria com o reconhecimento do casamento homossexual? 
Abrangendo pontos que conferem maior amplitude ao objeto geral da dissertação, o quarto capítulo do trabalho analisará tais questões, que em última análise dizem respeito aos limites da moralidade pública. Tomo como ponto de partida o famoso debate ocorrido entre Patrick Devlin e Herbert Hart na década de 60, tendo por foco as conclusões da Comissão Wolfenden, responsável pelo estudo de propostas de descriminalização da homossexualidade e da prostituição na Inglaterra. Também analisarei a síntese dworkiniana sobre referido debate, elaborada no texto Lord Devlin and the enforcement of morals (DWORKIN, 1966), que busca responder à questão de quando podemos considerar as posições dos indivíduos como "posições morais" - ou, em outras palavras, quando determinadas posições são justificáveis moralmente e não constituem meros preconceitos ou repetição de opiniões alheias. Mas o ponto alto deste último capítulo está na analise de ideias típicas do pensamento dworkiniano com o intuito de sustentar que o casamento homossexual deve ser reconhecido enquanto direito moral. As distinções entre ética e moral, entre liberty e freedom, e o papel do Estado diante do reconhecimento do direito de minorias em geral serão analisados com o fim de demonstrar que a restrição do casamento apenas aos casais heterossexuais configura uma afronta ao dever estatal de tratar os cidadãos com igual respeito e consideração. Por fim, ressalto a importância que trabalhos como este apresentam na fundamentação de decisões judiciais e na tarefa legislativa, que tem por objeto questões que possuam, primordialmente, uma natureza moral constatando-se a insuficiência de análises meramente legalistas e sem o devido aprofundamento filosófico.

O leitor poderá se questionar se este último capítulo não deveria ser dividido em vários outros e ser apresentado como uma "segunda parte" do trabalho, pela amplitude dos temas tratados. Por certo, os "limites da moralidade pública” representam por si só um tema complexo e desafiador, que a meu ver daria origem a inúmeras outras dissertações ou teses (o que já ocorre, ainda que de forma tímida aqui no Brasil). Entretanto, como afirmei anteriormente, minha preocupação maior está na análise conceitual do casamento. Acredito que é neste campo que posso dar minha maior contribuição, uma vez que as análises nacionais sobre o casamento ou o fazem a partir de uma perspectiva histórica, ou através da dogmática jurídica (ressaltando aspectos de Direito de Família ou princípios constitucionais). Mesmo que marcadas pela concisão (na realidade, justamente por isso), as reflexões presentes no último capítulo são aptas a responder afirmativamente à questão pelo reconhecimento do casamento como um direito moral das minorias sexuais. 


\section{UMA CONCEPÇÃO DE CASAMENTO - A POSIÇÃO DE JOHN FINNIS}

Como afirmado anteriormente, minha intenção com este trabalho é desconstruir uma perspectiva teórica que sustenta a impossibilidade do casamento entre pessoas do mesmo sexo, apresentando seus equívocos, para posteriormente desenvolver uma concepção que possa abranger, justificadamente, o matrimônio homossexual enquanto um direito moral. Certamente, existem diversas formas de se excluir conceitualmente lésbicas e gays do direito ao casamento. Pode-se afirmar, por exemplo, que está na essência do casamento a diversidade de gêneros, de modo que ele só poderia ocorrer entre um homem e uma mulher. Mas quais razões nos levariam a esta compreensão do matrimônio?

No Brasil, este é um argumento levantado por uma moral religiosa dominante. Com base em determinadas interpretações da Bíblia e outros textos sagrados, muitos religiosos argumentam que a homossexualidade (e, consequentemente, o casamento homossexual) é uma "abominação"16. A autoridade exercida por tais textos e suas interpretações funciona como dogmas que, por definição, não podem ser objeto de questionamentos. Assim, é difícil estabelecer um debate acerca da possibilidade ou não do casamento homossexual, levando-se em consideração a moral religiosa ${ }^{17}$.

Por outro lado, é possível sustentar que o casamento monogâmico, heterossexual e relacionado à procriação tem por base critérios racionais, e que outras formas de

\footnotetext{
${ }^{16}$ No Brasil, são comuns as manifestações de personalidades como Silas Malafaia e Jair Bolsonaro acerca da homossexualidade. No exterior, notadamente nos Estados Unidos, tornou-se emblemática a posição do reverendo Charles Worley, que defende o "dever do Estado" de confinar homossexuais em um grande cercado elétrico e aguardar sua morte por inanição (cf. <http://www.correiobraziliense.com.br/app/noticia/mundo/2012/05/22/interna_mundo,303686/pastoramericano-que-defende-extincao-de-homossexuais-gera-indignacao.shtml $>$. Acesso em: 16 jul. 2012). Em qualquer caso, acredito que a maioria expressiva das posições contrárias à homossexualidade são marcadas pelo oportunismo e pela desonestidade intelectual. O deputado Jair Bolsonaro, inclusive, foi processado pela psicóloga Tatiana Lionço por ter "deturpado" suas falas em uma palestra na Câmara, dando a entender que ela estabeleceria uma relação necessária entre homossexualidade e pedofilia. Os vídeos e maiores detalhes sobre o ocorrido podem ser encontrados no seguinte site: <http://congressoemfoco.uol.com.br/noticias/manchetes-anteriores/psicologa-acusa-bolsonaro-de-deturparsua-opiniao/>. Acesso em: 19 ago. 2013.

${ }^{17}$ Isso não significa que todo e qualquer argumento religioso possa ou deva ser excluído do debate político. O fato de ser "religioso" não o destitui automaticamente de importância, pois muitas vezes está diretamente relacionado às convicções morais de um indivíduo. $\mathrm{O}$ fato de que tais convicções não sejam compartilhadas pelos demais também não é uma razão para desconsiderá-lo de plano: se sou favorável ao aborto, apresento razões que nem sempre são aceitas pelos outros, ainda que tais razões não sejam religiosas. Neste sentido, como poderia explicar a um indivíduo contrário ao aborto que seus argumentos não valem pelo fato de tomarem por base, por exemplo, a moralidade bíblica? O ponto, portanto, envolve complexidades que fogem ao âmbito deste trabalho e repercutem em temas como o da liberdade de expressão e o exercício da liberdade religiosa em um contexto político.
} 
casamento seriam construções irracionais e imorais. Creio que, neste sentido, a concepção de casamento elaborada por John Finnis se pretende racional e recorre a argumentos que, por sua natureza e complexidade, a transformam em uma sofisticada concepção de casamento enquanto união essencialmente heterossexual.

Embora pouco conhecida no Brasil, a obra de John Finnis tem sido debatida com muito interesse no contexto internacional. De origem australiana, Finnis foi aluno direto de Herbert Hart em Oxford, e acredito que conjuntamente com Ronald Dworkin e Joseph Raz é um dos grandes expoentes teóricos em questões de Filosofia Jurídica, Moral e Política, notadamente em países anglófonos.

Em linhas gerais, pode-se afirmar que John Finnis é um filósofo moral e jurista alinhado à perspectiva da "teoria analítica do Direito Natural", e uma de suas preocupações centrais está na desmistificação da forma pela qual muitos juristas (positivistas, notadamente) apresentam o Direito Natural. Em suas palavras,

\footnotetext{
Todo autor tem seu entorno: este livro tem raízes em uma moderna tradição que pode ser denominada "teoria analítica do Direito", e meu próprio interesse nesta tradição antecede o tempo em que eu comecei a suspeitar de que haveria muito mais nas teorias de Direito Natural além de superstição e obscuridade. Alguém que compartilhe minha teoria de Direito Natural, mas cujo foco de interesse e competência era, digamos, uma teoria sociológica do Direito, teoria política ou teologia moral, teria escrito um livro diferente (FINNIS, 2011b, p. vi, tradução livre).
}

Dessa maneira, em sua obra maior Natural Law and Natural Rights (FINNIS, 2011b) Finnis analisa os fenômenos morais e jurídicos sem recurso a fundamentos meramente metafísicos, como seriam erroneamente concebidas as teorias de Direito Natural por muitos teóricos positivistas (por exemplo, a perspectiva de que o "certo" e o "errado" decorre da vontade de uma entidade sobrenatural). A teoria finnisiana parte, ao contrário, de uma compreensão particular acerca do que seriam os "bens humanos básicos", relacionando-os com o que denomina serem as "exigências básicas da razoabilidade prática". É a partir daí que Finnis analisa pontos como a vida em sociedade, as questões afetas à justiça, aos direitos e obrigações dos indivíduos, o papel da autoridade etc. Depreende-se, portanto, que Finnis possui uma teoria geral do Direito que se filia à corrente teórica de Direito Natural de influência aristotélica e aquiniana - mas sem perder o estilo analítico herdado de Hart.

Entretanto, isso não significa que haja uma necessidade de se recorrer diretamente a Aristóteles e Tomás de Aquino para estabelecer uma crítica às posições defendidas por 
John Finnis - e este é um ponto que merece particular atenção. Ainda que, como se verá adiante, elementos de sua teoria (e de sua própria concepção de casamento) tomem por base uma interpretação do pensamento destes autores clássicos, os argumentos de índole moral e filosófica apresentados por Finnis devem ser capazes de se sustentar por sua própria razoabilidade ${ }^{18}$. Inclusive, esta é uma preocupação manifestada pelo próprio Finnis no prefácio de Natural Law and Natural Rights:

(...) é importante ressaltar que neste livro nada é afirmado ou sustentado por apelo à autoridade de qualquer pessoa ou corpo [de pensamento]. Frequentemente faço referências a Tomás de Aquino, porque em minha visão ele ocupa um lugar estratégico único na história da teorização sobre Direito Natural. Da mesma forma, ocasionalmente faço referências aos pronunciamentos da Igreja Católica Romana sobre Direito Natural, porque este corpo é, talvez, o único no mundo moderno que clama por ser um expoente de autoridade em Direito Natural. Mas, mesmo que haja espaço para o apelo ou deferência à autoridade, este espaço não é no argumento filosófico sobre os méritos de teorias ou a resposta correta para problemas práticos, e portanto não é neste livro. Meus argumentos, portanto, se sustentam ou caem por sua própria razoabilidade ou não (FINNIS, 2011b, p. vi, tradução livre).

De qualquer sorte, creio ser insuficiente analisar apenas a concepção finnisiana de casamento se o interesse maior da dissertação está em sua posterior crítica. Se para Finnis (2008, p. 2) o casamento constitui um “bem humano básico", é fundamental ter uma prévia compreensão sobre o que isso significa, assim como de outros elementos presentes em sua teoria de Direito Natural. Passo a expor, portanto, uma síntese de tais elementos e a forma pela qual os interpretei, tomando por base a sua obra principal - Natural Law and Natural Rights.

\subsection{O DIREITO NATURAL DE JOHN FINNIS}

Para Finnis, ciências sociais como o Direito buscam descrever, analisar e explicar determinado objeto. Entretanto, uma vez que este objeto constitui-se de ações humanas, ele não pode ser plenamente compreendido sem referência ao seu point, ao objetivo, valor,

\footnotetext{
${ }^{18}$ Neste sentido, por exemplo, cita-se o debate estabelecido entre John Finnis e Martha Nussbaum acerca das posições de Platão e Aristóteles sobre a homossexualidade na Grécia antiga, refletida nas obras The Good of Marriage and the Morality of Sexual Relations: Some Philosophical and Historical Observations (FINNIS, 1998) e Sex \& Social Justice (NUSSBAUM, 1999). Há flagrante divergência entre os autores sobre as possíveis interpretações dos pensamentos platônico e aristotélico, bem como às demais circunstâncias históricas da homossexualidade naquele contexto. Neste sentido, ainda que seja particularmente interessante a análise destas questões, acredito que o interesse principal seja a razoabilidade dos argumentos apresentados por Finnis, independentemente da sua origem aristotélica ou platônica. Para uma análise deste debate e sua repercussão no contexto jurídico americano, recomendo o artigo de Randall Baldwin Clark, Platonic Love in a Colorado Courtroom: Martha Nussbaum, John Finnis, and Plato's Laws in Evans v. Romer (2000).
} 
significado ou importância que os indivíduos atribuem às suas ações (FINNIS, 2011b, p. 3). Desta maneira, a descrição e a valoração do Direito seriam duas facetas da mesma moeda: não há como explicar o fenômeno jurídico sem, em algum momento, recorrer ao valor. Isso ocorre porque mesmo a descrição não corresponde a um mero empreendimento lexicográfico, de denominação de práticas sociais - pois os princípios pelos quais nomes são adotados e aplicados (as preocupações práticas e interpretações dos indivíduos cujas condutas constituem o objeto do teórico social) não são uniformes (FINNIS, 2011b, p. 4).

Considerando que descrição e valoração são, nesta medida, indissociáveis, Finnis busca transcender as teorias positivistas que se baseiam na neutralidade. Reconhece os avanços promovidos por positivistas como Hart e Raz, mas acredita que os critérios "nãovalorativos" para identificação do Direito resumem-se em meras diferenças de opinião sobre o que é importante e significativo no campo dos dados e da experiência na qual todos estes autores estão, em certa medida, familiarizados. Tal fato levanta uma questão relevante: sob qual ponto de vista, e com relação a quais preocupações, deve ser avaliado o que é "importante" e "significativo" (FINNIS, 2011b, p. 9)?

Partindo de Aristóteles, Finnis propõe a identificação de um significado focal do Direito. Não se trata, como teria sido proposto por Kelsen, de encontrar aqueles elementos descritivos ou explanatórios que culminassem em um "mínimo denominador comum", ou "máximo divisor comum", das diversas relações que poderiam ser chamadas de "Direito" (FINNIS, 2011b, p. 10). Ao contrário, trata-se de identificar um caso central ou paradigmático que não exclua a existência de outras relações (casos periféricos) que também possam ser concebidos como parte do fenômeno jurídico. Assim, como sugere Finnis (2011b, p. 11), é possível identificar casos centrais de governos constitucionais, e casos periféricos que, ainda assim, poderiam ser concebidos como sistemas jurídicos (como o regime nazista ou a Rússia stalinista) ${ }^{19}$.

Mas tais considerações apenas modificam os termos da questão anteriormente levantada: qual seria, então, o significado focal do Direito? O que define quais são os casos centrais e quais são os casos periféricos do fenômeno jurídico?

Finnis acredita que as tentativas de Hart e Raz para identificar o significado focal do Direito não foram longe o bastante. Neste sentido, por exemplo, o ponto de vista interno identificado por Hart seria um amálgama de vários pontos de vista diferentes (FINNIS, 2011b, p. 13). Afinal, nas palavras de Hart (1994, p. 203, tradução livre): “A obediência ao

\footnotetext{
${ }^{19}$ Pode-se perceber, portanto, que Finnis não assume a posição frequentemente atribuída aos jusnaturalistas de que somente sistemas jurídicos justos correspondem ao Direito.
} 
sistema pode ser baseada em muitas considerações diferentes: cálculos de interesse a longo prazo; interesse desinteressado nos demais; uma atitude irrefletida inerente ou tradicional; ou o mero desejo de fazer o que os demais fazem”. Isso demonstra que os critérios que identificam o que seria o tal "ponto de vista interno" são instáveis e insatisfatórios (FINNIS, 2011b, p. 13). Como afirma Finnis (2011b, p. 14), as atitudes concernentes ao ponto de vista interno sustentado por Hart (cálculos de interesses, atitude tradicional etc) não estão adequadas, efetivamente, à função do Direito enquanto mecanismo para solucionar verdadeiros problemas sociais. O que se tem é que:

Todas estas considerações e atitudes, portanto, são exemplos manifestamente desviantes, diluídos e enfraquecidos do ponto de vista prático que transforma o Direito em um tipo significantemente diferente de ordem social e o mantém como tal. Na verdade, eles são parasitários deste ponto de vista (FINNIS, 2011b, p. 14 , tradução livre).

Não é à toa que Finnis sustenta que o point ou caso central do Direito é dependente de ideais "morais". Somente assim o Direito diferencia-se de outras formas de ordem social, enquanto objeto apto a ser descrito pelo teórico (FINNIS, 2011b, p. 14-15) ${ }^{20}$. Todavia, o termo "moral" possui múltiplas conotações, o que torna preferível reduzir as conclusões finnisianas em termos de razoabilidade prática (FINNIS, 2011b, p. 15). Tal fato, inclusive, está em consonância com os objetivos de seu Natural Law and Natural Rights: identificar aqueles bens humanos que só podem ser garantidos através de instituições de direito humanas, e os requisitos de razoabilidade prática que apenas estas instituições podem satisfazer (FINNIS, 2011b, p. 3) ${ }^{21}$

Por hora, podemos entender a razoabilidade prática como a capacidade humana de decidir e se conduzir de acordo com o que deve ser feito ${ }^{22}$. O que se tem,

\footnotetext{
${ }^{20}$ Nas palavras de Finnis (2011b, p. 14/15): "If there is a point of view in which legal obligation is treated as at least presumptively a moral obligation (and thus as of 'great importance', to be maintained 'against the drive of strong passions' and 'at the cost of sacrificing considerable personal interest'), a viewpoint in which the establishment and maintenance of legal as distinct of discretionary or statically customary order is regarded as a moral ideal if not a compelling demand of justice, then such viewpoint will constitute the central case of the legal viewpoint. For only in such viewpoint is it a matter of overriding importance that law as distinct from other forms of social order should come into being, and thus become an object of the theorist's description".

21 "There are human goods that can be secured only through the institutions of human law, and requirements of practical reasonableness that only those institutions can satisfy. It is the object of this book to identify those goods, and those requirements of practical reasonableness, and thus to show how and on what conditions such institutions are justified and the ways in which they can be (and often are) defective" (FINNIS, 2011b, p. 3).

${ }^{22}$ Com as devidas cautelas, o que se observa é que Finnis em geral utiliza a expressão razoabilidade prática como uma espécie de qualidade ou propriedade de um indivíduo - tanto é que corresponde a um fim ou bem
} 
consequentemente, é que o teórico que busca descrever ações humanas (sejam elas jurídicas ou sociais em geral) não pode ignorar aqueles conceitos que as pessoas consideram apropriados para expressar o que consideram importante fazer ou alcançar, em face das contingências que as confrontam nas suas práticas (FINNIS, 2011b, p. 16).

O empreendimento teórico de John Finnis, como é possível perceber, vem a ser uma teoria de Direito Natural profundamente diferente de outros modelos teóricos que são associadas a esta corrente de pensamento. Ele apresenta duras críticas às formas com que alguns juristas (como Kelsen, Hart e Raz) apresentam o Direito Natural, afirmando desconhecer, por exemplo, qualquer filósofo jusnaturalista que derivaria a validade jurídica da validade moral - que defendesse a inexistência de um sistema jurídico que seja "legalmente válido", mas "moralmente errado" (FINNIS, 2011b, p. 26). Também seria incorreta a imagem de que o Direito Positivo seria ou deveria ser uma "mera cópia" do Direito Natural: para Finnis, interpretando Tomás de Aquino, o Direito Positivo é necessário na medida em que o Direito Natural não é capaz de prover todas ou mesmo a maior parte das soluções para os problemas de coordenação da vida em sociedade (FINNIS, 2011b, p. 28). Se não bastasse, ainda com Tomás de Aquino, o Direito Positivo seria suplementar aos requerimentos "naturais" da moralidade na medida em que compeliria os indivíduos egoístas a agir com razoabilidade, o que indica que a "contradição" apresentada por Kelsen (de que o Direito Positivo é uma ordem coercitiva, e que o Direito Natural não apenas não seria coercitivo, mas que na realidade proibiria qualquer coerção entre os homens) seria insustentável (FINNIS, 2011b, p. 29) ${ }^{23}$.

Enquanto uma teoria do Direito Natural, a obra de Finnis tem por base os princípios de Direito Natural. Eles abrangem:

(i) um conjunto de princípios práticos que indicam as formas básicas do florescimento humano como bens a serem buscados e realizados, e que são de uma forma ou de outra usados por qualquer um que considera o que fazer, não importa quão implausível sejam suas conclusões; e (ii) um conjunto de requerimentos metodológicos básicos da razoabilidade prática (em si uma das

humano básico. A razão prática, por sua vez, pode ser vista como a "razão", mas operando com vistas para a ação. Agradeço ao colega Horácio Neiva por esta observação.

${ }^{23}$ Outra crítica comumente dirigida aos jusnaturalistas, que Finnis (2011b, p. 30) atribui a Hart, diz respeito ao fato de que uma concepção de finalidade ou bens humanos a serem concretizados sempre será “complexa", "discutível” e "questionável”. Certamente, os indivíduos divergem em suas opiniões sobre o que é valioso ou importante. Entretanto, de acordo com Finnis (2011b, p. 31), o verdadeiro problema da moralidade não é discernir os aspectos básicos do bem-estar humano, mas sim integrar estes vários aspectos em compromissos, projetos e ações inteligentes e razoáveis, que contribuam para a formação de uma ou outra forma admirável de vida humana. Logo, "a genuine requirement of practical reasonableness is not the less a part of natural law (to use the classical phrase) just because it is not universally recognized or is actively disputed" (FINNIS, 2011b, p. 31). 
formas básicas do florescimento humano) que distingue pensamentos práticos plausíveis e implausíveis e que, quando tudo considerado, provê os critérios para distinguir entre atos que (sempre ou em circunstâncias particulares) são razoáveis-todas-as-coisas-consideradas (e não apenas relativas à propósito particular) e fatos que são irrazoáveis-todas-as-coisas-consideradas, ex.: entre formas de agir que são moralmente certas e moralmente erradas - tornando possível criar (iii) um conjunto de padrões morais gerais (FINNIS, 2011b, p. 23, tradução livre $)^{24}$.

É interessante frisar que princípios de Direito Natural, de forma semelhante a muitos princípios da lógica e da matemática, são considerados autoevidentes. Trata-se de princípios que não são demonstrados, que são indemonstráveis e que, ainda assim, são evidentes por si mesmos de forma semelhante aos princípios básicos da razoabilidade prática, de acordo com a interpretação finnisiana da teoria de Tomás de Aquino - é autoevidente, por exemplo, a proposição de que "o homem é um animal racional" (FINNIS, 2011b, p. 32).

A consideração de Finnis acerca da autoevidência e indemonstrabilidade dos princípios básicos de Direito Natural, notadamente os que constituem os chamados "bens humanos básicos", permite refutar a ideia de que as teorias morais de Direito Natural sustentariam que proposições sobre os deveres e obrigações dos homens seriam inferidos de proposições sobre sua natureza. Em síntese, seria incorreto atribuir à teoria finnisiana de Direito Natural o que se denomina de "inferência ilícita de normas a partir de fatos" - os princípios de Direito Natural são não inferidos de princípios especulativos, de fatos ou de proposições metafísicas sobre a natureza humana: além de autoevidentes e indemonstráveis, tais princípios não são derivados de qualquer outra coisa (FINNIS, 2011b, p. 33/34).

Mas de que maneira, então, seria possível apreender tais princípios? Para Finnis, sustentando-se em Tomás de Aquino, o raciocínio prático que busca concretizar as formas básicas dos bens humanos não é compreendido "exteriormente" (através de observações psicológicas, antropológicas ou metafísicas); ao contrário, ele deve ser entendido

\footnotetext{
${ }^{24}$ Não é à toa que princípios de Direito Natural, pela sua conformação, não possuem uma "história". Tais princípios são válidos por mais que sejam esquecidos, mal empregados ou desprezados pelo pensamento prático. Certamente, é possível descrever historicamente diferentes doutrinas de Direito Natural ou mesmo as diferentes formas pelas quais estes princípios foram considerados ao longo dos tempos; mas o Direito Natural, em si, não pode ser descrito historicamente. Nas palavras de Finnis (2011b, p. 24): "Natural law could not rise, decline, be revived, or stage 'eternal returns'. It could not have historical achievements to its credit. It could not be held responsible for disasters of the human spirit or atrocities of human practice. But there is a history of the opinions or set of opinions, theories, and doctrines which assert that there are principles of natural law, a history of origins, rises, declines and falls, revivals and achievements, and of historical responsibilities". É neste sentido que Finnis está preocupado em elaborar uma teoria do Direito Natural, ao invés de uma teoria sobre as doutrinas de Direito Natural.
} 
internamente, na medida em que somos capazes de "experienciar" nossa própria natureza, em que temos consciência de nossas inclinações - o que, novamente, não representa nenhum processo de inferência (FINNIS, 2011b, p. 34). Consequentemente, os princípios básicos de Direito Natural não são princípios morais. Os princípios básicos de Direito Natural e os princípios da razoabilidade prática são princípios "pré-morais", de onde são derivados, ao seu turno, princípios propriamente morais (o que seria "certo" ou "errado") (FINNIS, 2011b, p. 34) ${ }^{25}$. Consequentemente, para Finnis a maneira pela qual se descobre o que é moralmente certo ou errado não é perguntar o que se encontra de acordo com a natureza humana, mas sim o que é razoável - questão esta que irá, eventualmente, nos levar ao encontro dos princípios inderivados da razoabilidade prática, que fazem referência às formas de bem humano (FINNIS, 2011b, p. 36) ${ }^{26}$.

Como é possível perceber, a teoria finnisiana concede especial atenção à razão humana. A razão, quando direcionada a um fim, corresponde à razão prática. Nela se encontra não apenas a capacidade humana de se formular razões que fundamentem o discernimento sobre o que é desejável ou não (o que poderia ser entendido como a já mencionada razoabilidade prática), mas a própria capacidade de agir com base nestas razões - em busca do que se considera bom e valioso (FINNIS, 2011c, p. 1). É a partir do exercício da razão que somos capazes de delimitar o que consideramos relevante para nossas vidas e para a vida em comum.

\footnotetext{
${ }^{25}$ Pode parecer curiosa, em um primeiro momento, a ideia de "princípios pré-morais". Os princípios básicos de Direito Natural e os princípios da razoabilidade prática não são "morais" na medida em que, por si, não dizem o que é "certo" ou "errado", "bom" ou "ruim". Com as devidas cautelas, é possível dizer que eles são "princípios" por possibilitarem a ação e, ao mesmo tempo e justamente por isso, por corresponderem a "fins" de uma ação humana. Toda ação humana tem um fim, que corresponde também ao seu princípio. Mesmo as ações de um ladrão contém, em si, um "princípio": ele só age porque sua ação tem um fim. Podemos imaginar que o ladrão furta celulares para revendê-los e garantir seu sustento - ou, do mesmo modo, que é para garantir seu sustento (e aí estaria o "princípio") que furta celulares. Nesta hipótese, o fim (e princípio) é inteligível, racional. Garantir o próprio sustento não é em si algo bom ou ruim. A moralidade (o "certo" ou "errado" da ação) se encontra nos meios de que se vale o indivíduo para alcançar seus fins, na forma com que se conduz. É neste sentido que julgaríamos como imoral a ação do ladrão, mas não os princípios e fins que o motivaram a agir. Maiores esclarecimentos sobre este ponto podem ser encontrados no artigo O Primeiro Princípio da Razão Prática, de Germain Grisez (1965), que também será abordado em momento posterior deste trabalho - notadamente no terceiro capítulo, como parte da crítica à posição de John Finnis.

${ }^{26}$ Certamente, a questão da "inferência ilícita de normas a partir de fatos" não se encerra neste breve resumo. Finnis elabora, no segundo capítulo de Natural Law and Natural Rights, uma complexa descrição dos pormenores históricos que levaram muitos filósofos e juristas a atribuírem tal perspectiva aos expoentes do Direito Natural. Aborda, notadamente, diferentes interpretações da "lei de Hume", de que não haveria como derivar um "dever ser" de um "ser", bem como as posições adotadas por Samuel Clarke e seus antecessores, Hugo Grotius e Gabriel Vazquez. O tema, ainda que interessante, envolveria a análise de pormenores que extrapolam o objeto do presente trabalho, sem contribuições diretas à análise conceitual do casamento que aqui proponho. Por tal razão, remeto o autor que tiver interesse no assunto à leitura do segundo capítulo de Natural Law and Natural Rights (FINNIS, 2011b).
} 
Para Finnis, a razão nos permite identificar determinados bens e princípios de Direito Natural que, como afirmado anteriormente, são autoevidentes, indemonstráveis e inderivados. Eles se relacionam diretamente com qualquer boa razão para a ação e qualquer descrição completa da conduta humana (FINNIS, 2011b, p. 59), razão pela qual são denominados bens ou valores humanos básicos. A listagem de bens humanos básicos oferecida por Finnis ao longo de sua obra é variável, mas uma síntese de seu último posicionamento está no pós-escrito da segunda edição do Natural Law and Natural Rights. São eles: o conhecimento (knowledge), o desempenho hábil no trabalho e em jogos (skilful performance), a vida corpórea (bodily life), a amizade (friendship), o casamento (marriage), a razoabilidade prática (practical reasonableness), e a harmonia com a fonte última de toda a realidade (harmony with ultimate source) (FINNIS, 2011b, p. 448) ${ }^{27}$.

Estes bens humanos básicos constituem aquilo que toda e qualquer pessoa racional, em maior ou menor grau, busca e considera relevante em sua vida. $\mathrm{O}$ exemplo básico é o conhecimento. É difícil conceber uma pessoa ou sociedade que não valorizem o conhecimento, que não busquem se aprimorar intelectualmente. Conhecer algo, por si só, já é um bem - e pode-se afirmar que a busca pelo conhecimento satisfaz uma inclinação natural do homem à curiosidade, indo além de eventuais interesses instrumentais (de um ponto de vista utilitário, do conhecer para poder) (FINNIS, 2011b, p. 60). Mesmo argumentos contrários são auto-refutáveis: afirmar que inexistem verdades absolutas sobre o conhecimento já implica em formular uma compreensão que se pretende correta e verdadeira sobre a natureza do conhecimento, correspondendo a uma contradição performativa - exemplo semelhante seria a famosa proposição socrática, "só sei que nada sei”, que também é auto-refutável (FINNIS, 2011b, p. 74).

\footnotetext{
27 Originalmente, são valores básicos a vida, o conhecimento, o jogo, a experiência estética, a amizade (sociabilidade), a razoabilidade prática e a religião (FINNIS, 2011b, p. 85-90). A experiência estética passou a ser vista como um tipo de conhecimento, e a criação artística, o trabalho e o jogo passaram a integrar conjuntamente a ideia de desempenho hábil (FINNIS, 2011b, p. 448). Já a religião pode ser interpretada como "harmonia com as fontes últimas", e não representa a mera crença em alguma entidade transcendental; antes, ela reflete o fato de que buscamos estabelecer uma ordem entre a busca dos outros bens básicos mencionados e a existência duradoura do cosmos, assim como respostas para o que torna possíveis a liberdade e a razão humana, que se elevam acima do mero determinismo do instinto (FINNIS, 2011b, p, 89). Certamente, outros bens humanos podem ser acrescentados à lista finnisiana a partir do processo reflexivo, e outros autores chegaram a listas ligeiramente diferentes e em geral mais extensas (FINNIS, 2011b, p. 92). Ademais, o próprio casamento não constava em sua listagem original. O importante é entendermos o papel que eles exercem na teoria finnisiana pela busca racional do bem humano, de termos uma vida valiosa. Devemos compreender o que eles simbolizam ao invés de absorver de maneira acrítica a listagem oferecida por Finnis. Como recomenda Raymond Wacks (2012, p. 25), "Do not simply swallow Finnis's assumptions unthinkingly. You will gain considerably more from a critical reading of his analysis (of which I have provided only the barest of bones) than from committing to memory his seven basic goods plus nine basic requirements of practical reasonableness as if it were a mathematical formula".
} 
Os outros bens básicos são estruturados de forma semelhante. Para delimitá-los, devemos nos perguntar, antes de tudo, se é racional nos questionarmos se não são bens em si mesmos (FINNIS, 2011b, p. 85/86). Assim, por exemplo, é possível sustentar racionalmente que o conhecimento, a vida ou a amizade, por exemplo, não constituem bens básicos que devem ser mantidos e aperfeiçoados pelo indivíduo e pela coletividade?

O bem básico do conhecimento é tratado em todos os seus pormenores no terceiro capítulo de Natural Law and Natural Rights. Outros bens básicos são tratados no capítulo quarto e em artigos posteriores à primeira edição do livro. Não se deve esquecer que na medida em que constituem bens humanos básicos (e que não deixam de ser princípios de Direito Natural) não são valores propriamente morais, como afirmei anteriormente. $\mathrm{O}$ ingresso na esfera moral só ocorre posteriormente, através dos princípios da razoabilidade prática, o que será visto adiante.

Os bens humanos são considerados básicos em três sentidos fundamentais. Em primeiro lugar, cada um é, igualmente, uma forma autoevidente de bem. Em segundo lugar, nenhum pode ser reduzido a um mero aspecto ou faceta de outro bem básico, ou transformado em meio para se perseguir algum outro bem. E, por fim, cada um deles, quando alvo de nossas atenções, pode ser considerado razoavelmente como o mais importante - ainda que inexista alguma hierarquia objetiva entre eles, pois são bens incomensuráveis (FINNIS, 2011b, p. 92).

Este último ponto implica na consideração de que cada um dos bens humanos básicos é igualmente fundamental. Certamente, as limitações e contingências da vida humana não tornam possível uma existência que se dedique a contemplar todos os bens em pé de igualdade. Alguém que se dedica à busca pelo conhecimento, através da pesquisa acadêmica, estará privilegiando este bem em sua vida e poderá, eventualmente, considerar o bem do jogo como uma frivolidade (FINNIS, 2011b, p. 92). Mas, per se, não se pode afirmar que o conhecimento seja mais importante que os demais bens humanos básicos. A questão central é que as pessoas fazem escolhas em suas vidas, escolhas estas que são mais ou menos estáveis e passíveis de revisão, e que contemplam uma maior atenção na busca de determinados bens ao invés de outros. Logo, cada um de nós pode razoavelmente escolher tratar um ou outro bem como mais importante para nossa própria vida (FINNIS, 2011 b, p. 93$)^{28}$.

\footnotetext{
${ }^{28}$ É interessante ressaltar que os bens humanos são inesgotáveis. Uma vida inteira não seria o bastante para consumar, por exemplo, o bem do conhecimento. Consequentemente, Finnis (2011b, p. 96) sustenta ser mais
} 
É bom ter em mente que, ainda que existam inúmeros outros aspectos da autodeterminação dos indivíduos, estes aspectos (como generosidade, coragem, moderação, gentileza etc.) não correspondem a bens humanos básicos. São, antes de tudo, meios de se buscar os demais bens (FINNIS, 2011b, p. 90/91). Se não bastasse, nem todas as eventuais inclinações e ímpetos das pessoas correspondem a um bem humano básico, como seria a inclinação a se pegar mais do que aquilo a que se tem direito. Egoísmo e crueldade, ainda que eventualmente constituam inclinações e ímpetos humanos, carecem de explicações que outras inclinações como a curiosidade (que fundamenta o conhecimento) e a amizade não dependem (FINNIS, 2011b, p. 91).

Mas estas considerações ainda são insuficientes para responder à pergunta fulcral da moralidade: o que deve ser feito? De quais bens devemos participar e como estabelecemos nossa própria ordem de prioridades?

Para responder a tais questões, Finnis recorre ao único bem humano básico que nunca pode ser preterido, e que é "participado" justamente no momento em que os indivíduos tomam suas decisões com relação aos demais bem básicos. Trata-se da razoabilidade prática (FINNIS, 2011b, p. 100). Ela exerce um papel dominante na teoria finnisiana e diz respeito à capacidade humana de utilizar com eficiência a inteligência para a solução de problemas relacionados com a escolha de ações (“o que fazer?”), o estilo de vida que devemos possuir e o caráter que devemos cultivar. "Negativamente, isso implica que temos uma medida de efetiva liberdade; positivamente, isso implica que buscamos colocar uma ordem razoável e inteligente em nossas próprias ações, hábitos e atitudes práticas” (FINNIS, 2011b, p. 88, tradução livre). Trata-se, portanto, de um valor complexo que envolve liberdade e razão, integridade e autenticidade. E por ser constituída por uma série de exigências (requirements), a razoabilidade prática opera uma transição dos bens humanos, enquanto valores pré-morais, para aquilo que efetivamente pode ser chamado de "moral": para a tomada de decisões sobre projetos e ações que serão avaliados em termos de certo ou errado, de moral ou imoral.

Finnis elenca nove exigências da razoabilidade prática, os quais, assim como os bens humanos, constituem princípios de Direito Natural que são autoevidentes, indemonstráveis, incomensuráveis, irredutíveis e de igual importância. Elas são apresentadas de forma pormenorizada no quinto capítulo de Natural Law and Natural Rights (FINNIS, 2011b, p. 100-133) e são as seguintes: 1) ter um plano coerente de vida; 
2) não ter preferências arbitrárias entre os valores básicos; 3) reconhecer uma imparcialidade fundamental entre os sujeitos humanos que são ou podem ser partícipes destes mesmos bens; 4) assumir uma postura de distanciamento (detachment); 5) ter comprometimento $^{29}$; 6) agir de maneira eficiente, atentando à relevância limitada das consequências de nossas ações; 7) respeitar cada valor ou bem humano básico em nossa conduta; 8) promover o bem comum $^{30} ; 9$ ) agir de acordo com nossa consciência ${ }^{31}$.

Dentre estas exigências, acredito que a mais relevante para o presente trabalho seja a sétima: respeitar cada bem humano básico em nossas ações. As contingências da vida implicam no reconhecimento de que temos liberdade de autodeterminação - podemos considerar a participação em alguns bens como mais importante para nossas vidas do que em outros (como no caso de um cientista que busca o conhecimento, mas que evita cultivar com mais afinco o bem da amizade). O relevante para esta sétima exigência, interpretada conjuntamente com as demais, é que os bens humanos básicos (que são incomensuráveis) não sejam subordinados a qualquer projeto ou comprometimento pessoal - muito menos sentimentos ou até considerações de custo-benefício que tratariam tais bens de maneira comensurável (FINNIS, 2011b, p. 121-122). Em síntese, Finnis (2011b, p. 123, tradução livre) afirma que: "e para a maioria dos propósitos práticos esta sétima exigência pode

${ }^{29}$ A quarta e a quinta exigências devem ser compreendidas de forma conjunta. O fato de que a vida e a relação com outras pessoas e projetos sejam muitas vezes imprevisíveis ressalta a importância de que estejamos suficientemente abertos a todas as formas de bens humanos básicos. Isso significa que dedicar todas as forças e energias a um único objetivo ao longo da vida, esperando apenas resultados positivos, poderá ser insensato - o objetivo pode vir a nunca ser alcançado, o que faria com que a pessoa pensasse que sua vida não teve valor. Há, portanto, um requisito de desprendimento ou distanciamento, no sentido de se evitar dar a um determinado projeto a importância primordial ou incondicional que só deveria ser cultivada por bens humanos básicos. Por outro lado, se uma postura "fanática" deve ser sempre evitada, da mesma forma o devem ser a apatia, o fracasso irracional e a recusa em se "envolver" com qualquer coisa. Logo, o quinto requisito da razoabilidade prática vem a ser o comprometimento - o fato de que compromissos adotados não deverão ser abandonados levianamente (FINNIS, 2011b, p. 110).

${ }^{30} \mathrm{O}$ favorecimento e promoção do bem comum em nossa comunidade constitui a oitava exigência da razoabilidade prática. Esta exigência possui os mais variados significados (FINNIS, 2011b, p. 125): desde a promoção do bem alheio em uma relação de colaboração ou coordenação com outra pessoa (FINNIS, 2011b, p. 139), passando pelas preocupações típicas de uma relação de amizade (FINNIS, 2011b, p. 141), e a busca pela concretização do bem comum em uma comunidade política (FINNIS, 2011b, p. 154). Estes inúmeros significados decorrem das variadas formas com que pode ser analisado o bem comum. Para Finnis, tratamos por bem comum o conjunto de condições que possibilitam aos indivíduos perseguirem seus próprios objetivos - em uma comunidade política, tem-se a preocupação em garantir este conjunto de condições, materiais ou não, que possibilitam a realização, por parte de cada indivíduo, de seu desenvolvimento pessoal (FINNIS, 2011b, p. 154). Uma boa explicação sobre a forma com que Finnis concebe o bem comum pode ser encontrada no artigo em que Neil MacCormick analisa a obra de John Finnis, Natural Law Reconsidered (MACCORMICK, 1981).

${ }^{31}$ Esta exigência está relacionada com a responsabilidade individual por nossas ações. Isso indica ainda que todos têm uma "dignidade intrínseca": todos devem ser respeitados, quaisquer que sejam as consequências, em cada ato e no todo, enquanto aspecto da plenitude da existência pessoal (FINNIS, 2011b, p. 126). 
ser resumida como: não escolha diretamente contra um valor básico ${ }^{, 32}$. Este ponto é particularmente importante na medida em que, como explicarei adiante, Finnis considera as relações homossexuais contrárias ao bem humano básico do casamento: a expressão da sexualidade fora do matrimônio corresponderia a uma espécie de "reificação" ou "instrumentalização" do corpo que é incompatível com a própria dignidade e que, por consequência, afronta diretamente este bem e vai em sentido contrário à sétima exigência da razoabilidade prática.

De qualquer forma, o produto destas exigências corresponde à moralidade. Nem toda exigência terá um papel direto em cada juízo moral, mas muitos juízos morais resumem uma ou mais exigências da razoabilidade prática. O relevante é perceber que cada uma destas exigências pode ser pensada como um modo de obrigação moral ou responsabilidade (FINNIS, 2011b, p. 126). A razoabilidade prática, repita-se, exerce um papel de conexão entre questões de cunho prático e os bens humanos básicos, sendo estes pré-morais.

A teoria exposta em Natural Law and Natural Rights abrange outros tópicos. As ideias de comunidade, justiça, direitos, autoridade e obrigação, por exemplo, são tratadas pormenorizadamente por Finnis. Mas na medida em que minha intenção é analisar especificamente a ideia finnisiana de casamento enquanto questão conceitual, creio que tenha sido suficiente tratar, ainda que de forma breve, da sua proposta teórica geral e de suas ideias sobre os bens humanos básicos e os requisitos da razoabilidade prática.

\subsection{A CONCEPÇÃO FINNISIANA DE CASAMENTO}

Para Finnis, o casamento constitui um dos bens humanos básicos que devemos valorizar e do qual podemos participar. Sua inclusão no rol de bens humanos básicos, como mencionei, se deu posteriormente à primeira edição de Natural Law and Natural Rights, em artigos e textos diversos. Neste sentido, creio que o principal artigo a ser analisado é Marriage: a Basic and Exigent Good (FINNIS, 2008). Nele, Finnis delimita o que compreende ser o significado focal do casamento. Como visto na hipótese do Direito, o significado focal do casamento envolveria a compreensão daqueles elementos que

\footnotetext{
${ }^{32}$ Esta exigência também pode ser tratada de outras maneiras. De acordo com Finnis (2011b, p. 122): “[...] this 'seventh requirement' is well-recognized, in other formulations: most loosely, as 'the end does not justify the means', more precisely, though still ambiguously, as 'evil may not be done that good might follow therefrom'; and with a special Enlightenment flavor, as Kant's 'categorical imperative': 'Act so that you treat humanity, whether in your own person or in that of another, always as an end and never as a means only,',.
} 
constituem o caso central deste conceito. Não se trata de meros acordos e estipulações linguísticas, mas sim de elementos que nos permitam articular, sumariamente, um conjunto de julgamentos avaliativos fortes sobre um campo da possibilidade ou prática humana (FINNIS, 2008, p. 1). Segundo Finnis (2008, p. 1, tradução livre):

\begin{abstract}
Articular tais julgamentos é contribuir com o discurso oferecendo um conjunto de proposições para consideração e discussão crítica. A discussão correrá bem apenas se aqueles que dela participam estão atentos de que, em última análise, isso é preparatório para a formulação de julgamentos e escolhas que, sendo mais do que discursivas, mudam vidas.
\end{abstract}

O point do casamento, para Finnis, seria duplo: o matrimônio tem por alvo a procriação (ou cuidado com a prole) e a amizade entre os cônjuges. Estas características estariam unidas de maneira tão singular que torna possível afirmar que o casamento é um tipo de bem tão básico e constitutivo da realização humana a ponto de ser intrinsecamente valioso (FINNIS, 2008, p. 2). Se não bastasse, estes pontos demonstram que o casamento vai muito além de uma dimensão jurídica, de um status oficial reconhecido pelo Direito. Em suas palavras,

\begin{abstract}
Qual é seu point? Esta é a primeira questão sobre qualquer ato, ou tipo de ato. A resposta que dou para a questão sobre o point do casamento irá se estender por todo este artigo. Ela começa com dois pensamentos sumários: o point do casamento é duplo, procriação e amizade, e o casamento é um dos tipos de bem humano tão básico e constitutivo da realização humana que cada point pode ser considerado um bem intrínseco (...) A compreensão de que este bem de dois lados é uma oportunidade profundamente desejável e exigente implica em que o casamento seja completamente mal compreendido quando concebido como nada mais do que um status oficial imposto pela lei, e acompanhado dos direitos e mandamentos governamentais (FINNIS, 2008, p. 1; 3, tradução livre).
\end{abstract}

É importante mencionar que, assim como os demais aspectos da teoria finnisiana, os pontos em questão são fundamentados a partir de um exercício de reflexão racional e não mediante justificações religiosas e dogmáticas. Neste sentido, Finnis (1997, p. 3, tradução livre) é explícito:

\footnotetext{
A posição moderna padrão envolve um número de julgamentos explícitos ou implícitos sobre o papel adequado do Direito e dos interesses demandantes das comunidades políticas, e sobre o mal da conduta homossexual. Eles podem ser defendidos através de argumentos reflexivos, críticos, publicamente inteligíveis e racionais? Eu acredito que podem. O julgamento de que isso é moralmente errado não precisa ser uma manifestação nem de mera hostilidade a uma minoria odiada, nem de crença puramente religiosa, teológica ou sectária.
} 
Não é difícil perceber que o "ideal de procriação", considerado valioso apenas em um contexto matrimonial, torna a concepção finnisiana de casamento inapropriada para a defesa do casamento homossexual, pois a procriação só é possível a partir da união entre homem e mulher. A ideia de procriação contém, portanto, elementos que geram muitas críticas por parte daqueles que se posicionam contrariamente à Finnis. Como explicar, por exemplo, o casamento de indivíduos estéreis?

\subsubsection{A ideia de união biológica e amizade entre os cônjuges}

$\mathrm{O}$ ato da procriação, para Finnis, independe da efetiva geração de novos seres humanos. Filhos não constituem uma consequência inexorável do casamento. A reprodução é uma função que só se opera através da união dos órgãos reprodutivos do homem e da mulher, unindo-os biologicamente - e esta realidade biológica não é um mero "instrumento", mas parte da realidade pessoal de cada indivíduo, conforme sustenta em seu artigo Law, Morality and "Sexual Orientation" (FINNIS, 1997, p. 8). A questão, portanto, não está diretamente relacionada à geração da vida, mas sim à conduta direcionada à realização de atos de tipo reprodutivo - o que Finnis denomina união biológica. Finnis (1997, p. 9, tradução livre) a define nos seguintes termos:

\footnotetext{
União biológica entre humanos é a união inseminatória do órgão genital masculino com o órgão genital feminino; em muitas circunstâncias ela não resulta na geração, mas ela é a conduta que une biologicamente porque é a conduta que, enquanto conduta, é adequada para a geração. ${ }^{33}$.
}

Desta forma, a união biológica só pode ocorrer mediante a união entre homem e mulher; estéreis ou não, seus órgãos genitais não deixam de serem órgãos reprodutivos. É através deste tipo de relação sexual que os cônjuges "atualizam" e "experimentam" o bem do casamento, relação esta que subsiste na eventual esterilidade em casais heterossexuais ${ }^{34}$,

\footnotetext{
${ }^{33}$ Disso não decorre que a união biológica seja apenas uma união entre o pênis e a vagina. Ela envolve, também, um ato consensual e intencional de união dos órgãos genitais: "The organic unity which is instantiated in an act of the reproductive kind is not so much the unity of penis and vagina (as my inexact wording in the footnote quoted at 23 at $n .75$ incautiously suggests) but rather the unity of the man and the woman - the unity which is consummated in their intentional, consensual act of uniting those genital organs in seminal emission/reception in the woman's reproductive tract”' (FINNIS, 1998, p. 43). Este ponto também me parece reforçar a posição contrária de Finnis com relação à utilização de preservativos, o que será visto adiante.

${ }^{34}$ Esta união prosseguirá, conceitualmente, passível de ser identificada com o casamento mesmo que não compartilhe da completude (fullness) que pode existir na união entre homem e mulher férteis correspondente à efetiva geração e criação de filhos. Dessa maneira, o casamento heterossexual entre indivíduos estéreis não consiste em um caso central de casamento, mas em um caso secundário ou periférico,
} 
mas que não ocorre entre indivíduos homossexuais. Logo, nas palavras de Finnis (1997, p. 8-9, tradução livre):

\begin{abstract}
A união dos órgãos reprodutivos de marido e mulher os une verdadeiramente de forma biológica (e sua realidade biológica é parte, e não meramente um instrumento, de sua realidade pessoal); reprodução é uma função e, no que diz respeito a esta função, os esposos são uma realidade. Assim, sua união no ato sexual de tipo reprodutivo (neste caso, se ou não verdadeiramente reprodutivo ou mesmo capaz de resultar na geração) pode atualizar e permitir que eles experienciem seu verdadeiro bem comum. (...) Mas o bem comum de amigos que não são e não podem ser casados (por exemplo, homem e homem, homem e menino, mulher e mulher) não tem relação com o fato de terem filhos entre si, e seus órgãos reprodutivos não podem transformá-los em uma união biológica (e, portanto, pessoal). Logo, seus atos sexuais conjuntos não fazem o que eles esperam ou imaginam. Porque a ativação de um ou ambos os seus órgãos reprodutivos não pode atualizar e experienciar o bem marital - o que é possível no intercurso marital (intercurso entre esposos de uma maneira marital), mesmo entre esposos que são estéreis - eles não podem fazer nada mais do que prover a cada parceiro uma gratificação individual.
\end{abstract}

É interessante que esta ideia de "gratificação" ou mesmo de satisfação sexual mútua, quando ocorre de maneira distinta da união biológica, é considerada por Finnis como a instrumentalização dos indivíduos envolvidos, que "desintegram a si mesmos" (FINNIS, 1993, p. 12) ${ }^{35}$. Assim, atos sexuais de natureza homossexual seriam criticados de maneira semelhante à cópula entre humanos e animais, porque importariam em uma atividade sexual humana meramente "instintiva", dissociada da expressão de um bem comum inteligível e tratando a existência corpórea humana enquanto existência meramente animal (FINNIS, 1997, p. 11). Consequentemente, o "sexo marital”, por definição, acaba sendo a racional utilização dos órgãos reprodutivos masculino e feminino - por serem órgãos reprodutivos, só são capazes de realizarem a função reprodutiva quando unidos. Não há, portanto, uma união biológica nos atos sexuais de natureza homossexual, onde se operaria uma verdadeira instrumentalização dos indivíduos envolvidos (bem como nos casos de sexo heterossexual que não condigam com este tipo de união - e.g., sexo oral). $\mathrm{O}$ sexo homossexual seria por definição irracional, ainda que a satisfação dos indivíduos seja mútua, e incompatível com a própria ideia casamento.

que ainda assim pode ser tratado sob a luz do matrimônio. Nas palavras de Finnis (1998, 41-42): “The marriage of a sterile couple is true marriage, because they can intend and do together all that any married couple need intend and do to undertake, consummate, and live out a valid marriage. It cannot have the fullness that a fertile marriage can have, and in that respect is a secondary rather than a central-case instantiation of the good of marriage".

${ }^{35}$ Em outra passagem relevante, Finnis (1997, p. 9) afirma: “(...) that conduct involves the partners in treating their bodies as instruments to be used in the service of their consciously experiencing selves; their choice to engage in such conduct thus disintegrates each of them precisely as acting persons". 
Isso não significa, entretanto, que todo ato de união biológica será, em si, marital. Como visto anteriormente, o casamento também envolve a amizade entre os cônjuges, o que faz com que relações sexuais fora do matrimônio sejam tão irracionais quanto relações de natureza homossexual. Ainda que exista uma união biológica entre, por exemplo, um homem e uma prostituta, a ausência de comprometimento (i.e., a "amizade conjugal") impede que este tipo de "união" represente um casamento. Esta busca do "prazer pelo prazer" igualmente implica em uma instrumentalização dos indivíduos, pois a sexualidade só poderia se manifestar racionalmente em um plano adequado de envolvimento pessoal, que é o matrimônio (FINNIS, 1997, p. 9) ${ }^{36}$. Outras formas de se conceber a sexualidade fora do casamento corresponderiam a tentativas ilusórias da imaginação, e não na participação no bem do casamento em sua verdadeira significação - como um bem humano básico (FINNIS, 2008, p. 6-7) ${ }^{37}$. Se não bastasse, há casos em que mesmo dentro do casamento a união biológica poderá não ser marital: quando a relação sexual for "despersonalizada", o que ocorre quando se trata o cônjuge como meio para se buscar apenas o prazer e satisfação sexual, seja ela mútua ou não, sem se preocupar com a promoção da amizade conjugal e, consequentemente, do bem do casamento (FINNIS, 1997, p. 14) $)^{38}$.

\footnotetext{
${ }^{36}$ De acordo com Finnis (2008, p. 7): "Sex acts cannot be marital in kind unless they actualize, express and enable the spouses to experience not only their commitment to their marriage but also their marriage's dual point. Whatever the person or persons engaging in it imagine or suppose, a sex act cannot do that unless it actualizes, expresses and enables the experiencing of a marriage's freely chosen commitment to equality between the spouses, exclusivity, permanence, and openness to procreation".

${ }^{37}$ Robert George (2010) assume posição análoga: "Although not all reproductive-type acts are marital adulterous acts, for example, may be reproductive in type (and even in effect), but are intrinsically nonmarital - there can be no marital act that is not reproductive in type. Masturbatory, sodomitical, and other sexual acts that are not reproductive in type cannot unit persons organically: that is, as a single reproductive principle. Therefore, such acts cannot be engaged in for the sake of marital (that is, one-flesh, bodily) unity as such. They cannot be marital acts. Rather, persons who perform such acts must be doing so for the sake of ends or goals that are extrinsic to themselves as a bodily persons: sexual satisfaction, or (perhaps) mutual sexual satisfaction, is sought as a means of releasing tension, or obtaining (and sometimes sharing) pleasure, considered either as an end-in-itself or as a means to some other end, such as expressing affection, esteem, friendship, and so forth. In any case, where one-flesh union cannot (or cannot rightly) be sought, sexual activity necessarily involves the instrumentalization of the bodies of those participating in such activity to extrinsic ends".

${ }^{38}$ Disso não decorre que inexiste lugar para o prazer no ato da união biológica. Quando marcado pela união biológica e amizade entre os cônjuges, o sexo pode ser prazeroso e corresponder a um dos motivos (mas nunca o único) para se engajar no "intercurso marital". Esta seria, de acordo com Finnis, a posição de Tomás de Aquino: "His condemnation of such de-personalized and de-maritalized sex acts is completely compatible with his constant thesis that pleasure is a proper, indeed providentially appointed, motive for engaging in marital intercourse. Moreover, Aquinas' objection to de-personalized sex has no exclusive connection with pleasure, and manifests no special suspicion of pleasure. For he makes it clear that there is the same kind of wrong - and venial or serious, depending on how far one's act is de-maritalized - whenever one's motive for engaging in intercourse is solely one's health or solely 'cooling off', i.e. the reduction of one's own temptations to extra-marital sex" (FINNIS, 1998, p. 10). E prossegue: "For throughout the whole order of things (as Aristotle had made abundantly clear) we find that reasonable, morally decent action tends to be accompanied and certainly is perfect in pleasurable fulfillment (fruitio). Only when it is unhinged from
} 
É muito interessante ressaltar que os atos de natureza sexual que não correspondam à união biológica e/ou que se encontrem fora do casamento, afrontam o sétimo requisito da razoabilidade prática, pois refletem uma escolha que nada mais faz do que desrespeitar um bem humano básico. Tal requisito, aliado à liberdade que cada indivíduo possui de definir de forma razoável quais bens básicos privilegiará em sua vida, faz com que aqueles que não desejam se comprometer com o bem do casamento devam permanecer celibatários. Do contrário, estariam afrontando o bem do casamento e agindo de forma imoral ${ }^{39}$. Assim, nas palavras de Finnis (2008, p. 7, tradução livre):

\begin{abstract}
Alguém que razoavelmente escolha uma forma de vida valiosa que implica em responsabilidades incompatíveis com o comprometimento e responsabilidades do casamento não escolherá contrariamente ao bem do casamento, a não ser que ele ou ela engajem em atos sexuais (em cada caso a escolha para engajar tais atos é contrária a este bem pela razão já mencionada: em síntese, considerar razoável engajar-se em atos sexuais não-maritais implica em considerar que os atos sexuais de homem e mulher casados não atualiza, expressa ou permite, verdadeiramente, que eles experienciem seu casamento).
\end{abstract}

Resta clara, portanto, a relevância da ideia de união biológica na concepção de casamento elaborada por John Finnis. Ela corresponde a um elemento conceitual do matrimônio, formando seu significado focal. Se não bastasse, quando interpretada à luz dos requisitos da razoabilidade prática, torna todo e qualquer ato sexual fora do modelo matrimonial finnisiano um ato de imoralidade.

Tal circunstância também transforma em uma imoralidade a aprovação "deliberada" de pessoas que consideram o sexo fora do casamento uma questão de liberdade. Assim, mesmo a crença de que o matrimônio é importante, mas que o sexo pode ser praticado fora de seu contexto, corresponde a uma irracionalidade e ofende o bem humano básico do casamento (FINNIS, 1998, p. 35-36). Consequentemente:

\begin{abstract}
Assim, a completa exclusão, em nossa consciência, de atos sexuais não-maritais do campo de opções humanas aceitáveis e valiosas é existencialmente, se não logicamente, uma pré-condição para o caráter verdadeiramente marital do intercurso como e com um esposo. A aprovação deliberada de atos sexuais nãomaritais está entre os estados mentais (compreensão e disposição) que lesionam nossa capacidade de escolher e considerar como maritais mesmo aqueles atos sexuais que, em todos os outros aspectos, são de tipo marital. Este é um estado
\end{abstract}

consistency with practical reason's requirements does the pursuit of pleasure become morally defective" (FINNIS, 1998, p. 20).

${ }^{39}$ Como sustentei anteriormente, para Finnis a moralidade é produto das exigências da razoabilidade prática, as quais atuam como elemento de ligação entre os bens humanos básicos (pré-morais) e as ações humanas. Assim, a afronta a uma ou mais exigências implica em uma conduta imoral (cf. FINNIS, 2011b, p. 126-127), de forma que os atos sexuais fora do casamento e/ou contrários à ideia de união biológica (como as relações sexuais de natureza homossexual) seriam, também, imorais. 
mental que, mesmo entre essas pessoas que não estão interessadas em se casar, é contrária e viola o bem do casamento (FINNIS, 1998, p. 36, tradução livre $)^{40}$

Além da prática de atos que em essência são de tipo reprodutivo, o outro point do casamento consubstancia-se na existência de um vínculo especial, de natureza afetiva, entre os cônjuges. Não se trata de uma amizade pura e simples, que por si corresponde a um bem humano básico; na realidade, trata-se de uma amizade da qual os cônjuges participam de maneira apaixonada e orientada para a prática de atos de tipo reprodutivo (i.e., a união biológica). Por tal razão, não se deve pensar que o casamento "deriva" da amizade - enquanto bem humano, o casamento é inderivado, autoevidente, incomensurável e indemonstrável, de forma que suas características o tornam único diante dos demais bens humanos básicos. Logo, a união biológica e a amizade representam duas faces da mesma moeda - tais elementos, quando unidos, simbolizam o bem do casamento.

Isso ocorre porque, de acordo com a interpretação finnisiana de Tomás de Aquino, mesmo quando homem e mulher se unem com o único propósito de terem filhos, esta união será moralmente "imperfeita” caso não esteja direcionada a algum outro bem marital (FINNIS, 1998, p. 12) ${ }^{41}$. O outro bem em questão seria o que Aquino denominaria fides, que não poderia ser traduzido com segurança para "fidelidade". Isso ocorre porque a fides envolveria não apenas a abstenção de relações extraconjugais (i.e., o adultério), mas também corresponderia a um motivo para a ação (FINNIS, 1998, p. 13).

Indo além da abstenção do adultério (fidelidade negativa), a fides possui um aspecto positivo que corresponde à disposição e comprometimento de cada esposo em "apegar-se" (cleave to; accedere) um ao outro não apenas corporeamente (pela união biológica), mas também mentalmente, espiritualmente - fatos que constituem uma

\footnotetext{
${ }^{40}$ Finnis (1998, p. 36/37) prossegue: “Without the possibility of truly marital intercourse the good of marriage is seriously impaired. Any willingness (no matter how conditional) to engage in non-marital sex undermines, radically even when not perceptibly, one's marriage itself as a reality to be initiated, fostered, and preserved in and by clear-headed deliberation and the work of an alert and well-formed conscience (...) And this unhinging or disintegration threatens - runs contrary to - both the goods inherent in the complex basic good of marriage: not only the good of marital friendship and fides but also the good of procreation and of the children whose whole formation is so deeply benefited by the context of a good marriage".

41 De acordo com Robert George (1999, p 141): “(...) Grisez, Finnis and ourselves, reject the instrumentalizing of marriage and marital intercourse to any extrinsic end, including the great good of having and rearing children. In our view, children conceived in marital intercourse participate in the good of their parents' marriage and are themselves non-instrumental aspects of its perfection; this, spouses rightly hope for and welcome children, not as 'products' they 'make', but, rather, as gifts, which, if all goes well, supervene on their acts of marital union. The intrinsic intelligible point of the sexual intercourse of spouses, however, is, in our view, marriage itself, not procreation considered as an end to which their sexual union is the means".
} 
"fidelidade positiva" ${ }^{42}$. Trata-se do auxílio mútuo, o compartilhamento de uma vida em comum em um lar (FINNIS, 1998, p. 16).

A fides, consequentemente, corresponde a um motivo, a uma razão para a ação. Mesmo o "intercurso marital" seria um "ato de justiça", pois não haveria razão em se abster de atos que ambos os cônjuges razoavelmente esperam que ocorram. Logo, para Finnis (1998, p. 17/18, tradução livre):

\begin{abstract}
Assim, fides é um motivo - uma razão - para muitos atos cooperativos intrínsecos ou incidentais do compartilhamento de uma "vida completa" no domicílio conjugal. Como um motivo racional para se escolher participar em um ato de intercurso marital, ela é, simplesmente, podemos dizer, o bem projetado para experienciar e de forma particular atualizar o bem do casamento - de nosso casamento precisamente como nosso vínculo, e pertencimento mútuo, em tal relacionamento cooperativo exclusivo e permanente. Cada um de nós tem direito à cooperação do outro nestes atos, não havendo razão para a abstenção. Logo, o intercurso marital verdadeiro é, literalmente, um ato de justiça, de dar ao outro o que ele ou ela podem razoavelmente esperar. $E$ isso não impede que corresponda também a um ato de amor
\end{abstract}

Mas Finnis acredita que mesmo o comprometimento com a permanência e exclusividade marital, a fidelidade negativa, seria particularmente difícil de ser encontrada entre homens gays, até porque parceiros do mesmo sexo são incapazes de praticar atos de tipo reprodutivo. Assim, é curioso perceber que ele levanta não apenas argumentos de cunho filosófico para justificar sua concepção de casamento, mas busca argumentos empíricos que, em tese, tornariam implausível a defesa do casamento homossexual. Neste sentido, Finnis afirma:

\begin{abstract}
Apenas uma pequena proporção dos homens que vivem como "gays" se esforça seriamente em algo semelhante ao casamento enquanto comprometimento permanente. Apenas uma minúscula proporção se esforça na fidelidade marital, no comprometimento com a exclusividade; a proporção dos que acreditam que este esforço faz sentido, tendo em vista outros aspectos de sua "identidade gay", é menor ainda. Assim, mesmo no nível da conduta - e.g. mesmo deixando de lado sua esterilidade natural - o "casamento" gay, precisamente porque exclui ou não dá sentido ao comprometimento inteiramente central ao casamento, é uma simulação (...) Parceiros do mesmo sexo não podem se engajar em atos de tipo reprodutivo, no intercurso sexual marital. Para eles, o comprometimento permanente, exclusivo do casamento - no qual a união corporal em tais atos é o funcionamento biológico racional de uma relação marital em vários níveis (corporal, emocional, intelectual e volitivo) - é inexplicável. Certamente, duas, três, quatro, cinco ou qualquer número de pessoas do mesmo sexo podem se unir e criar uma criança ou crianças. Isto pode ser, em algumas circunstâncias, um
\end{abstract}

\footnotetext{
${ }^{42}$ Segundo Finnis (1998, p. 15): "This positive fides is the willingness and commitment to belong to, and be united in mind and body with, one's spouse in the distinct form of societas and friendship which we call marriage. This societas is a unique type of relationship; it is unified by its dual point (finis): the procreation, nurture, and education of children, and the full sharing of life in a home".
} 
comprometimento louvável. Mas nada tem a ver com casamento (FINNIS, 1998, p. 46/49, tradução livre).

Em síntese, apenas a união entre homem e mulher, para John Finnis, é capaz de corresponder a uma união verdadeiramente matrimonial. $\mathrm{O}$ ato sexual, enquanto união biológica, só é razoável (e moral) quando tiver por fim a participação no bem do casamento - que enquanto bem humano básico, não deixa de corresponder a um efetivo princípio de Direito Natural. Proteger o casamento heterossexual acaba se transformando em uma exigência da moral, já que a "simulação" desta união por pessoas do mesmo sexo é um procedimento ilusório, uma conduta que não tem por fim a participação em qualquer outro bem humano básico ${ }^{43}$ e que, inclusive, afrontaria o bem do casamento desrespeitando o sétimo requisito da razoabilidade prática ${ }^{44}$.

\subsubsection{Outras questões e implicações da posição finnisiana sobre o casamento - I}

\subsubsection{Divórcio}

A finalidade dupla do casamento marcada pela união biológica (em particular seu resultado, a geração e criação de filhos) e amizade conjugal justificam, para Finnis, a ideia de que a união marital deva ser exclusiva e permanente. Em suas palavras,

Assim, a racionalidade da disposição para uma união marital exclusiva e permanente surge ao se descobrir as implicações do bem dual delineado em seções prévias deste ensaio: as necessidades e interesses das crianças lhes dá o direito, certamente não de forma absoluta, mas verdadeira e exigentemente, a uma firme intenção e comprometimento dos pais na manutenção de um espaço de vida comum em cooperação mútua, pai e mãe, cada um com crianças que são e tem o direito de serem tratadas como suas, em um relacionamento completamente diferente em tipo da relação entre produtores com seus produtos, ou proprietários com sua propriedade, e muito mais parecido em tipo com aquela de amigo com amigo (FINNIS, 2007, p. 16, tradução livre).

\footnotetext{
${ }^{43}$ Não seria possível afirmar que esta união seria uma espécie de amizade, pura e simplesmente, uma vez que também envolve a prática de atos de natureza sexual (que só podem ocorrer dentro do bem do casamento, na forma da união biológica entre homem e mulher).

${ }^{44}$ Finnis (1997, p. 21) sintetiza: “(...) the artificially delimited (two-person, lifelong...) category named 'gay marriage' or 'same-sex marriage' corresponds to no intrinsic reason or set of reasons at all. It has few presentable counterparts in the real world outside the artifice of debate. Marriage, on the other hand, is the category of relationships, activities, satisfactions, and responsibilities which can be intelligently and reasonably chosen by a man and a woman, and adopted as their integral commitment, because the components of the category respond and correspond coherently to a complex of interlocking, complementary good reasons: the good of marriage. True and valid sexual morality is nothing more, and nothing less, than an unfolding of what is involved in understanding, promoting, and respecting that basic human good, and of the conditions for instantiating it in a real, non-illusory way - in the marital act”.
} 
Mas Finnis está ciente de que as falhas ou faltas de um ou de ambos os cônjuges podem ocasionar a ruptura desta amizade e, consequentemente, levar à dissolução do casamento. $\mathrm{O}$ destino nem sempre sopra em favor daquilo que os cônjuges originalmente pretenderam - tornando razoável a separação e compreensível a busca de um novo começo através de um novo compromisso marital (FINNIS, 2007, p. 15) ${ }^{45}$. Mas como fica o compromisso assumido, o "até que a morte os separe”?

Finnis sustenta que admitir o "recasamento" faz com que o compromisso de se criar um vínculo exclusivo e permanente com o outro corresponda a uma promessa ilusória (FINNIS, 2007, p. 15). Mas é importante ressaltar que não são os "votos" do casamento em si que tornam sua exclusividade e permanência moralmente obrigatórias; na realidade, é a "verdade moral" anterior e independente destas promessas que as justificam moralmente e geram a obrigatoriedade de se manter o vínculo conjugal $^{46}$. A obrigação estaria fundamentada justamente por 1) inexistirem boas razões para se acreditar que os indivíduos sejam incapazes de se comprometer de maneira irrevogável e 2) pela complementariedade dos fins do casamento (i.e., a geração e criação dos filhos, e a amizade entre os cônjuges), que demandam a ideia de que ele possa e deva ser afirmado como um vínculo indissolúvel (FINNIS, 2007, p. 16).

Mas se há a obrigação moralmente justificada de se manter o vínculo conjugal de forma indissolúvel, como é possível defender a "razoabilidade" do divórcio e a busca por um novo casamento, quando eventualmente finda a amizade conjugal? Finnis não estaria assumindo uma posição paradoxal? Na medida em que defenderei adiante os equívocos da concepção finnisiana de casamento, aí incluirei minhas críticas à sua posição quanto ao divórcio. Por hora recorro ao "princípio da caridade" e me limito a apresentar o que entendo ser a melhor interpretação possível para este suposto paradoxo.

$\mathrm{O}$ primeiro ponto que devemos ter em mente diz respeito à força obrigatória variável e invariante das promessas, o que é tratado no capítulo nono do Natural Law and

\footnotetext{
45 "And then there are the travails, failures, miseries of many who have made the commitment of true marriage in its central form, but whose hopes of it have been betrayed by the fault of one or both of them, or by some other kind of rupture or dissolution of their friendship which makes it reasonable for one or both of them to separate from the other and end their living together as spouses (divortium a mensa et thoro) - and wholly understandable if they (and their friends) wish also that each could start afresh in a new marital commitment to a new spouse" (FINNIS, 2007, p. 15).

46 "The bond (vinculum) of marriage is in each case unquestionably dependent upon choice, the will of the parties to it to enter upon commitment, by their exchange of promises, that is, their contract or covenant of marriage here and now (de praesenti) But such acts of will could not have the moral effect of making it true that the parties are morally obligated, that is, bound to each other in the way and to the extent they undertake, unless it is morally true, prior to and independently of their promising, that such promises can rightly be made and have the enduring morally binding effect they profess and intend (at the time of their making) to have" (FINNIS, 2007, p. 15-16).
} 
Natural Rights (FINNIS, 2011b). Finnis sustenta que uma promessa elaborada de forma apropriada sempre é uma razão exclusionária ${ }^{47}$, o que significa dizer que ela sempre fornece uma razão para se desconsiderar algumas razões as quais, na ausência da promessa de se fazer algo (e.g., permanecer casado "até que a morte os separe"), seriam genuínas, relevantes e suficientes para justificar a ação contrária (divorciar-se) (FINNIS, 2011b, p. 308). Mas ainda que corresponda a uma razão exclusionária, inúmeras circunstâncias podem fazer com que a regra geral de obrigatoriedade das promessas possa ser afastada. Nas palavras de Finnis:

\begin{abstract}
Mas uma promessa é geralmente uma razão exclusionária que pode ser vencida por algumas razões contrapostas, frequentemente por um amplo campo de razões prontamente disponíveis (embora nunca por quaisquer ou todas as razões que poderiam, na ausência da promessa, garantir o não cumprimento do prometido). Quando é pretendido pelas partes que a promessa seja uma razão exclusionária virtualmente invencível, a promessa será expressa com solenidade e precisão como uma que os obrigue "no melhor ou pior, na riqueza ou na pobreza, na doença ou na saúde... até a morte..." (e mesmo esta forma de palavras pode dar um significado reduzido de criação de obrigação pela prática na qual está enraizada). (...) A prática é permeada por virtualmente todas as considerações valorativas, não apenas aquelas que no terceiro nível de explicação dão às promessas sua força obrigatória, mas também por todas as outras considerações comparáveis (incomensuráveis ou não). Ou seja, o feedback de considerações sobre o bem individual ou comum não é apenas de considerações que busquem demonstrar porque é necessário cumprir com promessas em geral, e portanto com esta promessa em particular, mas também de considerações que demonstrem que neste ou naquele conjunto particular de circunstâncias a regra geral de obrigatoriedade possa, razoavelmente, ser considerada inaplicável ou suplantada (FINNIS, 2011a, p. 308-309, tradução livre).
\end{abstract}

\footnotetext{
${ }^{47}$ Finnis se vale da ideia de Joseph Raz acerca das razões exclusionárias (ou excludentes) não apenas quando pretende explicar a obrigatoriedade das promessas, mas notadamente quando busca estabelecer o significado focal do conceito de autoridade (FINNIS, 2011b, p. 234). De acordo com Raz (2010, p. 33), uma razão exclusionária não é apenas aquela que exclui algumas razões em nossos raciocínios práticos (i.e., razões para se fazer ou não fazer alguma coisa), mas pode também eliminar a necessidade de se ponderar entre diferentes razões. Em muitas situações, por exemplo, "o dever de aplicar a lei” corresponderá a uma razão exclusionária frente a outras razões que eventualmente poderiam ser levantadas (dura lex sed lex - a lei é dura, mas é lei). Dessa forma, "As razões excludentes são utilizadas para explicar casos em que, embora não haja dúvidas sobre aquilo que, depois de consideradas todas as coisas, deve ser feito, haja a crença de que a razão superada não seja simplesmente sobrepujada. Ela representa uma forma diferente de avaliar o que deve ser feito. Uma avaliação que não deve ser a base para a ação na situação presente, mas que tem certo grau de autonomia, manifesta-se em duas situações-teste: (1) Se fazemos mal quando agimos contrariamente àquilo que deveríamos fazer, todas as coisas consideradas, então nosso julgamento de que alguém fez mal porque agiu baseado em uma razão que é sobrepujada por outra é mais completo e inequívoco do que nossa condenação de um homem que agiu baseado em razões que, embora não sobrepujadas, foram excluídas por razões de segunda ordem, tais como a presença de uma autoridade ou fatos indicando que ele não deveria confiar em seu julgamento de mérito; (2) De modo inverso, embora aprovemos quando as pessoas fazem, todas as coisas consideradas, aquilo que deveriam fazer, nossa aprovação é mais completa e sem reservas quando as razões pelas quais agiram prevalecem na ponderação entre razões do que quando essas são razões que acarretam a superação, por assim dizer, de uma avaliação prática autônoma” (RAZ, 2010, p. 36-37).
} 
Assim, por exemplo, se prometo à minha avó que a acompanharei na missa de domingo, não poderei desobrigar-me de minha promessa na hipótese de uma simples chuva; mas se for uma chuva torrencial que cause caos urbano e me impossibilite de sair de casa, esta circunstância prática torna razoável que eu descumpra com o prometido. Transpondo esta ideia para o casamento, tem-se que razões supervenientes poderiam desobrigar os cônjuges da permanência e exclusividade no matrimônio, divorciando-se - o que não se confunde com as razões que justificam a obrigatoriedade do prometido, que correspondem aos fins do casamento.

$\mathrm{O}$ que se tem é que em um mundo ideal o casamento deve ser exclusivo e permanente. Pode-se dizer que, em seu significado focal, o casamento é indissolúvel. Este seria um dos fatores que diferenciam a amizade conjugal constante no casamento do bem humano básico da amizade ${ }^{48}$. Ocorre que eventuais adversidades do destino (e.g., traições) podem corresponder a razões que tornem a permanência do casamento insustentável para os cônjuges, desobrigando-os de seu comprometimento inicial e justificando o divórcio. Não é à toa que, para Finnis, os princípios de Direito Natural deixam inúmeras questões em aberto sobre os limites e implicações deste tipo de união, que devem ser resolvidas pelas autoridades, sejam elas eclesiásticas ou políticas:

\footnotetext{
Os princípios de Direito Natural deixam uma grande sorte de questões sobre os limites (e.g., como a consanguinidade) e as implicações de uniões deste tipo, sendo que todas devem ser resolvidas por determinatio pelas autoridades relevantes, eclesiásticas ou políticas, conjuntamente com muitas outras questões sobre os status dos cônjuges, propriedade, direitos inter se e em relação às crianças, na separação marital, dentre outras. Acredito que possa existir mesmo um campo para o Direito do Estado divergir dos contornos moralmente verdadeiros do casamento, assim como a Lei de Moisés sobre o casamento e o divórcio divergiram (e isso tem sido dito com alguma autoridade) em razão da “dureza de coração" das pessoas (FINNIS, 2007, p. 17, tradução livre).
}

Assim, justifica-se a divergência entre dispositivos da legislação estatal referentes à regulamentação do casamento (e do divórcio) e seus "verdadeiros contornos morais". O que não pode ocorrer é que estas divergências sejam amplas ao ponto de impedir que os indivíduos compreendam a "verdade" do casamento, a sua importância e o seu valor:

\footnotetext{
48 “(...) since the parenthood of both the spouses will, if it ensues, require them both and each to shape the whole of their lives with a view to the demands of being not only a good mother or good father but also a good partner for the whole of life - for richer for poorer, in sickness and in health - with a kind of commitment to exclusiveness and permanence which is not required for friendship as such" (FINNIS, 2011b, p. 448)
} 
Quanto mais ampla a divergência, maior o risco de que a verdadeira inteligibilidade do casamento, e assim a sua desejabilidade, sejam obscurecidos. Uma vez que casamentos, assim como sistemas jurídicos positivos, são realidades factuais cujo resultado e permanência dependam da compreensão, pelas pessoas, da verdade ("realidade", "valor") do casamento como um ideal, este risco deve ser aceito apenas com relutância, cautela e disposição para "voltar atrás", assim como "seguir adiante" (FINNIS, 2007, p. 17, tradução livre).

De qualquer forma, ainda se faz necessário expandir a interpretação que aqui formulo para não se chegar à conclusão de que o divórcio ofenderia a sétima exigência da razoabilidade prática (i.e., não afrontar diretamente um bem humano básico - no caso, o casamento). Não há como afirmar que minha interpretação corresponde àquilo que Finnis efetivamente diria sobre o assunto; mas na medida em que desconheço algum posicionamento expresso do autor sobre este ponto em específico, este esforço é imprescindível para não se concluir, de plano, que o divórcio ofenderia o bem humano do casamento da mesma forma que as uniões homossexuais. Do contrário, estaríamos diante de uma efetiva incoerência na concepção finnisiana de casamento e os argumentos que apresenta acerca do divórcio.

Do fato de que pessoas se casem e posteriormente se divorciem não decorre que o casamento não seja algo importante ou valioso, ou que eles não o tratem como tal ${ }^{49}$. $\mathrm{O}$ divórcio pode simplesmente simbolizar que, entre determinados indivíduos, a amizade conjugal simplesmente não foi possível: casar-se implica em redirecionar inclinações, rever alguns hábitos e construir novos projetos que, muitas vezes, são posturas difíceis e conflitantes quando os cônjuges apresentam personalidades completamente distintas ou incompatíveis ${ }^{50}$. Isso não significa que, com outra pessoa, um casamento estaria fadado ao fracasso. O que não pode ocorrer é agir de forma leviana, pois divorciar-se diante da primeira dificuldade, sem boas razões, implicaria em ofender a quinta exigência da razoabilidade prática - a do comprometimento com nossos projetos. Desse modo, entendo que admitir a possibilidade do divórcio não ofende as exigências da razoabilidade prática.

\footnotetext{
${ }^{49}$ De forma análoga ao acadêmico que, por ter pouca capacidade para a amizade e que se dedica apenas à busca pelo conhecimento, não pode de forma razoável negar que a amizade é um bem em si mesmo. É racional concentrar-se em um bem humano básico ao invés de outros, desde que não se estabeleça preferências arbitrárias entre estes bens - o que ofenderia a segunda exigência da razoabilidade prática (FINNIS, 2011b, p. 105).

50 "Commitment to the practice of medicine (for the sake of human life), or to scholarship (for the sake of truth), or to any profession, or to a marriage (for the sake of friendship and children)... all require both direction and control of impulses, and the undertaking of specific projects; but they also require the redirection of inclinations, the reformation of habits, the abandonment of old and adoption of new projects, as circumstances require, and, overall, the harmonization of all one's deep commitments - for which there is no recipe or blueprint, since basic aspects of human good are not like the definite objectives of particular projects, but are participated in" (FINNIS, 2011b, p. 104).
} 
Antes disso, está de acordo com a primeira (i.e., ter um plano coerente de vida ${ }^{51}$ ) e a quarta (i.e., o distanciamento ${ }^{52}$ ) exigências, garantindo aos indivíduos de boa-fé a chance de um novo começo.

Certamente, o divórcio envolve inúmeras questões de ordem normativa, sejam relacionadas à legislação estatal ou ao Direito Canônico ${ }^{53}$. Meu interesse aqui foi apenas abordar os pontos que estabelecem uma relação direta com a concepção finnisiana de casamento, qual seja a de um bem humano básico constituído pela amizade conjugal e pela procriação (efetiva ou tentada através da união biológica).

\subsubsection{2. "União estável” e direitos para homossexuais?}

A ideia de alguma união civil análoga ao casamento que abranja casais homossexuais (o que corresponderia à nossa união estável) não é contemplada por Finnis ${ }^{54}$. Isso porque a única forma de se constituir uma família é através do casamento. Na realidade, ambos os conceitos, de família e matrimônio, se confundem: pois o casamento é um bem básico simbolizado pela união dos fins da amizade conjugal e da procriação. Uma união homossexual seria, na melhor das hipóteses, uma simulação ilusória do casamento na medida em que tanto lésbicas quanto gays não são capazes de se unir biologicamente - o mundo das relações entre pessoas do mesmo sexo não ofereceria nenhum exemplo genuíno, equivalente ou contrapartida ao casamento, apenas pouquíssimas imitações sinceras (FINNIS, 1998, p. 50).

\footnotetext{
51 "For, from the imagined and heuristically postulated standpoint of the still unknown time of one's death, one can see that many sorts of choices would be irrational, a waste of opportunities, meaningless, a failure, a shame" (FINNIS, 2011b, p. 104-105).

52 "In order to be sufficiently open to all the basic forms of good in all the changing circumstances of a lifetime, and in all one's relations, often unforeseeable, with other persons, and in all one's opportunities of effecting their well-being or relieving hardship, one must have a certain detachment from all the specific and limited projects which one undertakes. There is no good reason to take up an attitude to any of one's objective eluded one, one would consider one's life drained of meaning” (FINNIS, 2011b, p. 110).

${ }^{53}$ São intensos os debates dentro da Igreja Católica Romana acerca do divórcio, da possibilidade de um novo casamento ou até mesmo acerca da sagrada comunhão por parte dos divorciados. Destaca-se a posição de Germain Grisez que, interpretando o Evangelho Segundo São Marcos e o Concílio Vaticano II, dentre outros, se posiciona contrariamente à possibilidade do divórcio, como se depreende no artigo Indissoluble marriage: a reply to Kenneth Himes and James Coriden (GRISEZ; RYAN, 2011). No artigo Indissolubility, divorce and holy communion (GRISEZ; FINNIS; MAY, 1994), que contou inclusive com a colaboração de John Finnis e William E. May, a posição de Grisez é de que casais divorciados não podem receber a sagrada comunhão.

54 Tive a oportunidade de questioná-lo pessoalmente acerca deste ponto na ocasião do Congreso Internacional sobre el Pensamiento de John Finnis, realizado em Buenos Aires nos dias 24 e 25 de novembro de 2011, ao que ele me respondeu com um claro e sonoro "I think not".
} 
E não poderia ser diferente: como visto, as relações homossexuais (ou, melhor dizendo, os atos homossexuais) são imorais na medida em que o sexo fora do casamento, que não corresponda à união biológica, não apenas representaria a instrumentalização do corpo como também ofenderia a sétima exigência da razoabilidade prática. Este ponto tem reflexos diretos na visão de Finnis sobre eventuais direitos dos homossexuais.

Finnis (1997, p. 1-3) defende o que denomina ser a "posição padrão moderna" (standard modern position) sobre a postura que o Estado deve assumir diante da homossexualidade:

\begin{abstract}
Durante os últimos trinta anos surgiu uma forma padrão de regulamentar juridicamente a conduta sexual. Esta "posição padrão moderna" tem dois braços. Por um lado, o Estado não está autorizado a, e não deve, tornar ofensa punível os atos sexuais imorais engajados consensualmente por indivíduos adultos em privado (por exemplo, atos homossexuais). Por outro lado, os Estados tem a autoridade para desencorajar a conduta e "orientação" homossexual (i.e., a disposição publicamente manifestada de, ativamente, se engajar em conduta homossexual). E tipicamente, embora não universalmente, eles o fazem. (...) A preocupação da posição padrão moderna não é, em si, com inclinações, mas inteiramente com certas decisões de exprimir ou manifestar deliberada promoção para a, ou disposição para engajar em, atividade/conduta homossexual, incluindo a promoção de formas de vida (e.g., suposta coabitação marital) que tanto encorajam tal atividade quanto a apresentam como uma alternativa válida ou aceitável ao comprometimento da união heterossexual que o Estado reconhece como casamento (FINNIS, 1997, p. 1, tradução livre).
\end{abstract}

Como se pode perceber, Finnis não defende a criminalização de atos homossexuais consensuais entre adultos, desde que realizados em privado (FINNIS, 1997, p. 2) ${ }^{55}$. Entretanto, a posição padrão moderna diferencia a supervisão da conduta privada de adultos da supervisão do ambiente público. Se na primeira hipótese não há qualquer tipo de intromissão estatal, na segunda ela estaria justificada pelo fato de que: 1) é no ambiente público que jovens são educados; 2) este é o contexto no qual todos têm uma responsabilidade de evitar que jovens se engajem em formas ruins de vida; 3) é o meio no qual e através do qual todos os cidadãos são encorajados a assumir um caráter integro e serem auto-controlados, e desencorajados das tentações, impulsos e busca pela mera gratificação sexual (FINNIS, 1997, p. 2).

\footnotetext{
${ }^{55}$ Robert George apresenta uma justificativa interessante para que nem todo ato imoral seja objeto de sanções penais. Trata-se das considerações de prudência (prudential considerations). Ele afirma: "But laws that are not unjust may be undesirable for other reasons. A particular moral law may itself violate no principle of justice, yet, in the circumstances, reasonably be judged undesirable. In the chapters that follow, I identify various prudential considerations that may militate against enforcing moral obligations. These considerations, which may or may not turn out to be conclusive in a particular case, rightly figure in the practical reasoning of legislators concerned to act wisely in the case of any proposed piece of morals legislation" (GEORGE, 1993, p. 2).
} 
Finnis prossegue afirmando que ativistas pelos direitos de lésbicas e gays confundem dois pontos que a posição padrão moderna cuidadosamente distingue: a) a disposição ou inclinação individual em direção à atividade homossexual e b) se conduzir de modo a expor ou manifestar, publicamente, apoio ou interesse à conduta homossexual e/ou formas de vida que presumivelmente envolvam tal conduta. Tal distinção tornaria a expressão "orientação sexual", utilizada com frequência pelos ativistas, radicalmente equivocada. Dessa forma, a posição padrão moderna proíbe (I) a discriminação com base na crença de que alguém seja sexualmente atraído por pessoas do mesmo sexo, mas não estende esta proteção às (II) atividades públicas que visam promover ou facilitar a conduta homossexual (FINNIS, 1997, p. 3):

\begin{abstract}
Assim, embora a posição padrão aceite que a discriminação com base nas disposições do tipo (I) sejam injustas, ela julga que há razões convincentes tanto para negar que esta injustiça seja corretamente remediada por leis contra a "discriminação baseada na orientação sexual", quanto para sustentar que tal "remédio" só funcionará com significativa discriminação e injustiça contra (e, na verdade, lesionará) famílias, associações e instituições que tem se organizado para viverem e transmitirem ideais da vida familiar que incluem uma importante concepção sobre o valor do intercurso sexual verdadeiramente conjugal (FINNIS, 1997, p. 3, tradução livre).
\end{abstract}

Em síntese, Finnis entende que não se deve estender aos homossexuais quaisquer direitos que, além da discriminação baseada no fato de que alguém tenha inclinações homossexuais (e.g., dificultando seu acesso ao mercado de trabalho), impliquem no reconhecimento de que a homossexualidade corresponda a uma forma de vida tão valiosa quanto a heterossexualidade, demarcada pela monogamia e permanência no casamento. Assim, até mesmo manifestações públicas de afeto entre duas mulheres ou dois homens, se forem entendidas como alusão à conduta homossexual, podem ser legitimamente repreendidas pelo Estado.

\title{
1.2.2.3. Adoção
}

A questão da adoção não é tratada de forma direta e específica nos textos de Finnis, mas sua concepção de casamento deixa clara a relação direta entre o matrimônio e a criação e educação de crianças, como se denota na seguinte passagem: 
infungibilidade das pessoas. O contrato entre os esposos, e o cumprimento de suas promessas, é em si um ícone não apenas das esperanças e conquistas passadas e futuras das famílias e seus integrantes, mas da cidadania livre e autonomamente direcionada. E seu comprometimento e fidelidade tecem a base de novos cidadãos, eventualmente independentes e responsáveis (FINNIS, 2007, p. 10, tradução livre).

Depreende-se que a conduta dos pais heterossexuais casados serve como bom exemplo na formação de seus eventuais filhos, uma vez que estes seriam criados em um ambiente onde seus pais efetivamente "participam" do bem humano básico do casamento. Mas este ambiente propício para a criação dos filhos seria comprometido caso uniões civis entre pessoas do mesmo sexo fossem admitidas, como sustentam Robert George, Sherif Girgis e Ryan Anderson (2010, p. 262-263, tradução livre):

\begin{abstract}
A consagração jurídica do casamento conjugal reforça socialmente a ideia de que a união entre marido e mulher é (tanto como regra como quanto ideal) o meio mais apropriado para a criação e educação de crianças - um ideal cujo valor é fortemente corroborado pela melhor ciência social disponível (...) Se parcerias do mesmo sexo forem reconhecidas como casamento, entretanto, este ideal seria abolido de nosso Direito: nenhuma instituição civil poderia reforçar a noção de que crianças precisam tanto de uma mãe quanto de um pai; de que homens e mulheres em geral têm diferentes dons no empreendimento parental; e de que meninos e meninas precisam e tendem a se beneficiar de pais e mães de formas diferentes. Neste caso, na medida em que alguns continuam a considerar o casamento como crucialmente ligado às crianças, a mensagem que seria enviada é de que uma casa com dois homens seria, em regra, apropriada para o contexto de criação de crianças, de modo que não importa (mesmo em regra) se crianças são criadas por ambas as suas mães ou ambos os pais, ou por pais de cada sexo.
\end{abstract}

Como se pode perceber, uma das preocupações destes autores se relaciona com a existência de "padrões" (masculino/feminino) que deveriam ser transmitidos às crianças para uma vida psicológica e social saudável, "como regra e ideal". Por certo, minha preocupação central neste trabalho não diz respeito à possibilidade ou não da adoção por homossexuais. Mas a possibilidade de adoção conjunta por um casal de mulheres ou homens pode ser vista como uma decorrência possível do reconhecimento do matrimônio entre pessoas do mesmo sexo. Afinal, se um homem e uma mulher podem se casar e ter seus filhos (inclusive através de adoção), por quais razões tal direito não poderia ser estendido à um casal homossexual? De qualquer modo, na medida em que este ponto não se relaciona diretamente com o conceito finnisiano de casamento, pretendo desde logo oferecer uma crítica à posição adotada por George, Girgis e Anderson - que, creio, muito provavelmente seria compartilhada por John Finnis caso se dedicasse ao tema.

Os estudos ("a melhor ciência social disponível”) que tais autores lançam mão para justificar suas convicções dizem respeito apenas à criação de crianças por seus pais 
biológicos em um casamento estável (GEORGE; GIRGIS; ANDERSON, 2010, p. 257$258)^{56}$. Mas eles nada mencionam sobre a eventual ausência dos pais biológicos ou outros fatores que justificariam a adoção. George, Girgis e Anderson não mencionam qualquer estudo que sustente, por exemplo, que a criação de uma criança abandonada pelos pais biológicos por outro casal heterossexual ou um casal homossexual seja social ou psicologicamente perniciosa ao menor. Logo, da convicção de que a criação de uma criança pelos pais biológicos seja vantajosa, em uma situação de normalidade, não decorre a afirmação de que a criação de uma criança órfã ou abandonada por pais adotivos, heterossexuais ou não, seja prejudicial. E disso não decorre também que a criação de crianças por pais heterossexuais seja melhor ou pior do que a criação por pais homossexuais. Na realidade, há mesmo pesquisas que indicam que, em determinados aspectos, as crianças criadas por lésbicas e gays podem se sair melhor do que aquelas que foram criadas em uma família heterossexual ${ }^{57}$.

É implausível acreditar que tais autores ou que Finnis se oponham à adoção por parte de um casal heterossexual, mas é de se imaginar que sejam absolutamente contrários quando se tratar de um casal de lésbicas ou gays. Neste caso, a única justificativa que poderia fazer sentido é a de que a conduta homossexual (que seria marcada pela imoralidade - i.e., a ofensa à sétima exigência da razoabilidade prática) pode obscurecer um "valor da parentalidade marcada pela diversidade de gêneros" (GEORGE; GIRGIS; ANDERSON, 2010, p. 262). Sustentarei mais adiante que as razões apresentadas para se considerar a homossexualidade imoral não subsistem, e que o valor da parentalidade não se confunde com o vínculo matrimonial. Ademais, se é garantido aos pares heterossexuais casados a possibilidade da adoção, o reconhecimento do casamento como um direito dos homossexuais só vem a fortalecer o argumento de que lésbicas e gays, uma vez casados, também possam legitimamente adotar e criar seus próprios filhos.

\footnotetext{
${ }^{56}$ George, Girgis e Anderson citam, por exemplo, uma pesquisa do Child Trends Research Brief, que tem a seguinte conclusão: "Research clearly demonstrates that family structure matter for children, and the family structure that helps children the most is a family headed by two biological parents in a low-conflict marriage. Children in single-parent families, children born to unmarried mothers, and children in step families or cohabiting relationships face higher risks of poor outcomes... There is thus value for children in promoting strong, stable marriages between biological parents... It is not simply the presence of two parents,... but the presence of two biological parents that seems to support children's development" (MOORE apud GEORGE; GIRGIS; ANDERSON, 2010, p. 258).

${ }^{57}$ Neste sentido, cita-se como exemplo a pesquisa realizada pela psiquiatra americana Nanette Gartrell, para o Estudo Nacional Longitudinal de Famílias Lésbicas dos EUA (NLLFS, na sigla em inglês). Gartrell afirma em sua pesquisa que os filhos de casais de lésbicas tiveram melhor desempenho na escola e nas interações sociais, se comparados aos garotos criados por famílias heterossexuais. É o que consta no artigos Filhos de gays se saem melhor do que os outros, da edição de fevereiro de 2013 da revista Superinteressante, disponível no site: <http://super.abril.com.br/cotidiano/filhos-gays-se-saem-melhor-outros-740042.shtml>. Acesso em: 08 nov. 2013.
} 


\title{
1.2.2.4. Métodos anticonceptivos e inseminação artificial
}

Como visto, Finnis admite o casamento entre um homem e uma mulher ainda que desta união não resulte a geração de uma nova vida. Consequentemente, a esterilidade involuntária de um ou de ambos os nubentes não é fator impeditivo para o matrimônio. Mas e se a esterilidade for voluntária, como na hipótese do homem que se submete à cirurgia de vasectomia? Ou, o que daria no mesmo, de que maneira devemos interpretar a atitude do casal heterossexual e fértil que opta por não ter filhos e recorre ao uso de métodos anticonceptivos?

Robert George (2010, tradução livre) analisa a questão, e reconhece que ela é de difícil solução:

\begin{abstract}
Certamente, um homem e uma mulher que se engajem no intercurso sexual podem empregar meios contraceptivos para garantir que as condições de reprodução não sejam obtidas. Pode o sexo com meios contraceptivos ser de tipo reprodutivo? A questão é difícil. Pessoas que compartilham a compreensão geral do casamento e dos atos maritais defendida neste artigo não são unívocas na resposta. Um ato de contracepção, embora realizado para facilitar um ato desejado de intercurso sexual ao reduzir as chances de que o ato resulte em uma concepção quando esta não é desejada, é distinto do ato de intercurso sexual que a facilita. Assim, algumas pessoas acreditam que a questão da moralidade da contracepção é independente da questão de se o ato de intercurso sexual preenche as condições comportamentais da reprodução. Aqueles que acreditam que a contracepção pode ser moralmente justificada em razão de tempo ou espaçamento entre gestações também acreditam que os esposos que empregam meios contraceptivos para tais propósitos não viciam a qualidade marital de seus atos de intercurso sexual. Estou inclinado à visão oposta. Onde alguém deliberadamente frustrou a possibilidade de concepção, não é claro para mim como alguém pode afirmar que este ato de intercurso sexual é de tipo reprodutivo.
\end{abstract}

Parece-me claro que Finnis considera o recurso a métodos anticonceptivos como uma forma de "desmaritalizar" o sexo no casamento ${ }^{58}$. Isso ocorreria porque o casal estaria, deliberadamente, evitando que o point reprodutivo do casamento seja alcançado. Não é à toa, portanto, que George considera que o ato sexual "deliberadamente frustrado pela possibilidade de concepção" não constituiria um ato de tipo reprodutivo. Há um elemento "voluntário" que diferenciaria a situação dos casais estéreis daqueles casais que,

\footnotetext{
${ }^{58}$ Neste sentido: “(...) my sex act with my spouse will not be truly marital - and will not authentically actualize, and allow us in a non-illusory way to experience, our marriage - if I engage in it while I would be willing in some circumstance(s) engage in a sex act of non-marital kind - e.g. adultery, fornication, intentionally sterilized intercourse, solitary masturbation or mutual masturbation (e.g. sodomy), and so forth" (FINNIS, 1997, p. 15)
} 
simplesmente, optam por não terem filhos. Os atos sexuais praticados por aqueles que são férteis, mas que ainda assim recorrem a métodos anticonceptivos, corresponderiam a uma afronta ao bem humano básico do casamento, notadamente na forma de ofensa ao sétimo requisito da razoabilidade prática. Tal ofensa ocorreria na medida em que esta conduta (assim como no sexo que busca apenas a satisfação física) não teria por alvo a promoção de outro bem humano básico ${ }^{59}$, mas sim a satisfação de um objetivo que não possuiria igual importância. Nas palavras de Finnis (2011b, p. 120/121, tradução livre):

\begin{abstract}
Escolher um ato que, simplesmente (ou primariamente), lesione um bem básico é engajar-se, quer queira quer não, em um ato de oposição ao valor incomensurável (um aspecto da personalidade humana) que se trata como se fosse um objeto de valor mensurável que pode ser superado por objetos comensuráveis de maior (ou cumulativamente maior) valor. Fazer isso, frequentemente, estará de acordo com nossos sentimentos, generosidade, simpatia e com nossos comprometimentos e projetos da maneira que nós os consideramos. Mas isso nunca pode ser justificado pela razão (...) A razão demanda que cada valor básico seja, ao final, respeitado em toda e cada ação. Se pudermos escolher diretamente um único ato que, em si, lesione e não promova algum bem básico, então podemos escolher diretamente programas, instituições e empreendimentos que em si mesmos lesionam e não promovam aspectos básicos do bem estar humano, levando em consideração uma "rede de consequências benéficas". Mas nós já vimos que as consequências, mesmo na medida em que elas podem ser "previstas como certas", não podem ser avaliadas de forma comensurável, o que significa que a "rede de consequências benéficas" é um objetivo ou critério geral literalmente absurdo.
\end{abstract}

O que se tem é o seguinte: se um casal fértil não pretende ter filhos, não deve se casar. Isso porque, ao recorrerem a métodos anticonceptivos, estariam frustrando de forma deliberada a participação no bem humano básico do casamento, motivados por objetivos que não correspondem a outros bens humanos básicos. Mas e se, por exemplo, o casal em questão for de pesquisadores que privilegiam o bem do conhecimento e acreditam (talvez de forma acertada) que filhos atrapalhariam a participação neste bem?

Nesta hipótese, acredito que Finnis recomendaria o celibato ao "casal", que no caso não mais seria um casal propriamente dito e sim dois amigos que vivem juntos - partícipes do bem da amizade - e que compartilham o ideal comum de participar do bem do conhecimento. Não se trataria de um casamento, e qualquer ato sexual entre ambos que recorra a métodos anticonceptivos deixaria de ser um ato de tipo reprodutivo. Ambos estariam se instrumentalizando e ofendendo ao sétimo requisito da razoabilidade prática, que determina o respeito pelos bens humanos básicos em cada conduta humana.

\footnotetext{
${ }^{59}$ Como seria o já mencionado caso do pesquisador que, visando participar no bem do conhecimento, deixa de participar do bem do jogo ou do bem da amizade.
} 
Outras dúvidas podem surgir quando se observa a intrínseca relação entre a união biológica e a amizade conjugal, que formam o bem do casamento. Como explicar e avaliar moralmente os avanços científicos que propiciaram a geração de novas vidas sem recorrer ao intercurso sexual? Qual a relação existente entre os métodos de reprodução assistida, como a fertilização in vitro, e o bem básico do casamento?

Como visto, o casamento constitui o meio adequado através do qual novas vidas podem ser geradas (FINNIS, 2007, p. 10). Crianças correspondem ao resultado esperado e desejado da união biológica, e devem ser vistas como pessoas - não como meros "produtos", "propriedade" ou "meios" para os fins de seus pais (GEORGE, 2010) ${ }^{60}$. Consequentemente, a fertilização in vitro não corresponderia à maneira moralmente mais adequada para a geração de novas vidas, pois a prática demonstra que este e outros métodos de fertilização artificial implicam em um verdadeiro "controle de qualidade, utilização e descarte" de embriões humanos, tratando-os como se fossem meros "produtos" (FINNIS, 2011a, p. 279). Para Finnis (2011a, p. 279, tradução livre),

\footnotetext{
Os grandes males da experimentação destrutiva, observação e seleção, são também sinais, acredito, do vício moral com o qual agora me preocupo: de decisões nas quais crianças humanas são encaradas como produtos. Pois produtos são tipicamente sujeitos a controle de qualidade, utilização e descarte. Outro sinal (menor) do mesmo vício é o fato de que aqueles que trabalham no campo da IVF [in vitro fertilization] frequentemente expressam ansiedade sobre o domínio [propriedade] dos gametas humanos com que trabalham e dos embriões humanos que produziram.
}

O fato é que, quando um casal opta pela reprodução assistida, está se colocando em uma posição de "domínio" que não é verdadeiramente parental. E este domínio seria inerente à ideia de fertilização in vitro, pois mesmo após a concepção os pais precisam de um ato distinto e positivo de escolha - autorizar a transferência do embrião para o útero da mulher (FINNIS, 2011a, p. 279). Logo, assim como no caso da utilização de métodos anticonceptivos, o que se observa é que a fertilização in vitro corresponde a uma espécie de controle externo dos resultados da união biológica. Por consequência, em regra seria

\footnotetext{
60 "Our concern is merely to explicate the sense in which children may be 'desired' or 'wanted' under a description that does not reduce them in principle - all sentimentality aside - to the status of 'products' to be brought into existence by their parents' wills and for their ends. (...) Children are treated by their parents, even in their conception, not as means to their parent's ends, but as ends-in-themselves; not as objects of desire or will of their parents, but as subjects whose fundamental interests as human beings are protected by principles of justice and human rights: not as property, but as persons" (GEORGE, 2010).
} 
incompatível com o bem humano básico do casamento, afrontando-o ainda que indiretamente ${ }^{61}$.

\subsubsection{Intersexualidade e transexualidade}

Inúmeros fatores são levados em conta quando pretendemos diferenciar homens de mulheres. O primeiro e mais "aparente" é justamente a genitália: ter um pênis ou uma vagina corresponde ao primeiro fator de identificação do recém-nascido como homem ou mulher. Têm-se ainda os pares cromossômicos XX e XY, que também funcionam como elemento de identificação da pessoa como mulher ou homem, respectivamente.

Entretanto, há situações nas quais estes e outros fatores são ambíguos. Há indivíduos que podem ter a aparência de uma mulher ou homem, mas por questões genéticas apresentam o par de cromossomos do sexo oposto, ou mesmo mais de um cromossomo - como é o caso da síndrome de Klinefelter, onde indivíduos em geral "identificados" como do sexo masculino possuem um cromossomo X adicional. Também é possível citar os hermafroditas e suas variações, que em regra possuem ambiguidade externa na morfologia genital. Diz-se que os indivíduos que se encontram nestas circunstâncias são intersexuais, não sendo possível defini-los com clareza como homens ou mulheres $^{62}$. E fora do campo estritamente biológico têm-se os transexuais ou transgêneros, que mesmo com a aparência física e a genética de um gênero, se identificam e se comportam como se fossem alguém do gênero oposto ${ }^{63}$.

61 Certamente, as questões éticas e morais envolvidas na reprodução assistida vão muito além das mencionadas. Minha intenção foi apenas estabelecer a relação (ainda que indireta) com a concepção finnisiana de casamento, uma vez que ela corresponderia a um bem humano básico que envolve a geração de novas vidas através da união biológica, que por sua vez só é moral no matrimônio. Entretanto, não creio que Finnis seja contrário a todas as formas de fertilização artificial, notadamente no caso de infertilidade masculina decorrente da baixa produção de espermatozoides. Nesta hipótese, me pareceria factível que a reprodução assistida fosse admissível, desde que qualquer possibilidade de "escolha" ou de "objetificação" do óvulo fecundado ou do embrião fosse afastada.

${ }^{62}$ Gerard Callahan, imunologista e professor da Universidade do Colorado, é autor de obras e estudos sobre o tema, destacando-se Between $X X$ and $X Y$ : intersexuality and the mith of two sexes. Uma entrevista interessante com o autor foi feita pela revista Época em julho de 2009 e pode ser encontrada no seguinte link: <http://colunas.revistaepoca.globo.com/mulher7por7/2009/07/22/ninguem-e-100-homem-ou-100-mulherestamos-todos-no-meio/>. Acesso em: 22 ago. 2012. Também é interessante o documentário realizado pela BBC em 2010, que retrata o drama de uma criança que, nascida menino, perdeu o pênis em uma cirurgia de circuncisão com sete meses de vida e que, a partir de então, passou a ser tratada pela família como menina. No mesmo documentário é retratada a questão da intersexualidade. É possível assisti-lo em: <http://topdocumentaryfilms.com/dr-money-boy-with-no-penis/>. Acesso em: 22 ago. 2013.

${ }^{63}$ Miriam Ventura, em seu artigo Transexualidade: algumas reflexões jurídicas sobre a autonomia corporal e autodeterminação da identidade sexual (2007), assim define a transexualidade: "A transexualidade pode ser definida como uma expressão da sexualidade, cujas principais características são o desejo de viver e ser identificado como pessoa do sexo oposto ao seu sexo biológico, e realizá-lo através da transformação de seu 
Mas quais as consequências da concepção finnisiana de casamento para indivíduos intersexuais e transexuais? Finnis não aborda diretamente esta questão em seus textos, mas tive oportunidade de questioná-lo no Congreso Internacional sobre el Pensamiento de John Finnis, realizado em Buenos Aires nos dias 24 e 25 de novembro de 2011, sobre a possibilidade de hermafroditas constituírem uma união matrimonial. Ele foi claro em sua resposta: "não”. E arrematou: "mas você vê um problema nisso?".

Infelizmente, não cheguei a questioná-lo sobre as razões para tal posição. Mas creio que o ponto se refere à impossibilidade de, na prática, identificar o hermafrodita como homem ou mulher do ponto de vista morfológico. Se o ato sexual de tipo reprodutivo implica na união entre um homem e uma mulher, que somente juntos se "unem biologicamente", não haveria como identificar a posição exercida pelo hermafrodita. O problema maior é que, além do hermafroditismo, há outros casos de intersexualidade que nem sempre correspondem a uma ambiguidade morfológica genital externa, ou até mesmo que resultem na esterilidade.

A questão complica ainda mais quando se observa que intersexualidade e orientação sexual (ou, como Finnis aparentemente prefere, a "inclinação sexual") são conceitos distintos. Deste modo, uma pessoa intersexual que em sua morfologia externa é considerada um homem e se identifica como tal pode se sentir atraída sexualmente por mulheres e, desta forma, ser um "homem" heterossexual. Aparentemente, não faz sentido que este indivíduo não pudesse se casar. Afinal, ele não poderia se "unir biologicamente" com uma mulher e, na hipótese de não ser estéril, gerar uma nova vida?

A concepção finnisiana de casamento deixa estas questões sem uma resposta muito clara. Acredito que a única forma de se manter coerência com a ideia de união biológica seja, justamente, valer-se de uma concepção puramente biologizante das diferenciações de gênero, qual seja a morfologia genital externa. Dessa forma, ter um pênis seria o fator determinante para ser um homem, enquanto ter uma vagina caracterizaria a pessoa como uma mulher. Afinal, esta é a distinção determinante para que se possa falar na união biológica, através da qual e conjuntamente com a amizade conjugal se participa do bem humano básico do casamento. Portanto, alguns casos de intersexualidade não seriam

corpo para o sexo/gênero vivenciado. O fenômeno transexual é definido, na Medicina e no Direito, como um tipo de transtorno psíquico, denominado na Classificação Internacional de Doenças (CID), pela OMS Organização Mundial de Saúde, como transtorno de identidade de gênero, e conhecido amplamente como transexualismo" (VENTURA, 2007, p. 142). 
fatores impeditivos ao matrimônio, ao contrário de outros que esbarrariam no conceito de união biológica ${ }^{64}$.

A situação dos transexuais, entretanto, é muito mais complicada. Pois a cirurgia de transgenitalização, aliada ao tratamento hormonal, "transforma" o que, a princípio, seria um homem em uma mulher - e vice-versa ${ }^{65}$. Um transexual que originalmente nasceu como um homem pode vir a se transformar em uma mulher, e do ponto de vista da morfologia genital externa, passa a ter uma vagina através de procedimento cirúrgico. Consequentemente, se a ideia de união biológica na teoria finnisiana só tem coerência se a distinção entre homens e mulheres se der através da morfologia genital externa, chega-se à conclusão que transexuais devidamente operados podem “unir-se biologicamente”. E se também são seres capazes de amar e de dividir com alguém a amizade conjugal, é plenamente factível admitir que possam se casar - de maneira análoga à situação de casais estéreis.

Duvido muito que Finnis concordaria com minhas conclusões sobre este ponto. Afinal, é contra intuitiva a ideia de que até mesmo transexuais possam conceitualmente se casar, e lésbicas e gays não. O problema é que sua concepção de união biológica é dependente, para responder estas situações intrincadas, de um entendimento prévio do que vem a ser um homem e uma mulher. E Finnis não aborda este ponto em momento algum. O que me resta é interpretar da forma mais coerente possível a ideia de união biológica à luz daquilo que ele efetivamente escreveu, e do fato de que existem intersexuais e transexuais no mundo que, assim como qualquer outro indivíduo, podem ter a intenção de se casar.

Neste capítulo, busquei explorar a concepção finnisiana de casamento. Como afirmei na introdução deste trabalho, esta é a posição mais refinada e coerente dentre os autores que se manifestam contrariamente ao casamento entre pessoas do mesmo sexo. Ela evita "lugares comuns" ou a mera reprodução de preconceitos e crenças religiosas. Logo, a

\footnotetext{
${ }^{64}$ Quanto questionei Finnis, referi-me apenas aos hermafroditas sem maiores especificações. Assim, creio que Finnis considerou as situações de efetiva ambiguidade na morfologia genital externa, quando não é possível dizer que a pessoa tem um pênis ou uma vagina ou ainda naqueles casos onde o indivíduo tem tanto um pênis como uma vagina (o "hermafroditismo verdadeiro"). Ambos os casos seriam impeditivos do casamento uma vez que, na primeira hipótese, não há como identificar morfologicamente o indivíduo como homem ou mulher; já na segunda hipótese, não parece fazer sentido que, na complementariedade entre um homem e uma mulher, haja a possibilidade de que alguém possa, eventualmente, exercer os dois papéis.

${ }^{65}$ A questão é tão complexa que fica praticamente impossível explicar o que se pretende sem utilizar aspas ou expressões como "a princípio", “com as devidas cautelas", dentre outras. Isso porque uma mulher transexual, por exemplo, seria justamente alguém que nasceu com características genéticas e físicas de um homem. O problema é que a existência tanto de transexuais quanto de intersexuais questiona justamente a plausibilidade da divisão de seres humanos em gêneros distintos.
} 
exposição de seus argumentos deve ser feita de forma justa e adequada, sem descurar dos pressupostos presentes ao longo de sua obra, que corresponde a uma verdadeira teoria de Direito Natural. Mas mesmo com todos os esforços possíveis de exegese para tornar coerente sua concepção de matrimônio, diante de questões como o divórcio, os métodos anticoncepcionais e até mesmo a intersexualidade, acredito que esta não seja uma boa forma de se concebê-lo.

O próximo passo é verificar a maneira através da qual devemos abordar o conceito de casamento, caso nossa intenção seja descobrir o seu sentido e significado em um contexto de práticas socialmente compartilhadas. Creio que, como sugere Ronald Dworkin, esta abordagem deve se dar de forma interpretativa. Assim, passo a expor alguns elementos da teoria dworkiniana, analiso o casamento enquanto um conceito interpretativo e verifico as compatibilidades deste tipo de análise com a concepção defendida por Finnis. Somente então será possível criticar diretamente a concepção finnisiana de casamento e apresentar minha própria concepção. 


\section{O CASAMENTO ENQUANTO CONCEITO INTERPRETATIVO - A POSIÇÃO DE RONALD DWORKIN}

Como mencionei na introdução do presente trabalho, minha intenção é analisar criticamente o conceito de casamento a partir da contraposição entre diferentes concepções. No capítulo anterior, busquei reconstruir o argumento de John Finnis acerca do matrimônio, demonstrando que sua concepção exclui cabalmente a possibilidade do casamento entre indivíduos do mesmo sexo. Para garantir plena inteligibilidade de sua concepção de casamento, também analisei aspectos importantes de sua obra Natural Law and Natural Rights, notadamente sua ideia de bens ou valores humanos básicos - dentre os quais, como visto, Finnis inclui o casamento - e as exigências da razoabilidade prática.

Posteriormente, pretendo expor minha concepção - que, como se verá, tem por base a teoria de Ronald Dworkin. Entendo que o casamento deve ser compreendido de forma interpretativa, que se relaciona diretamente com valores que compartilhamos socialmente, ajustando-se adequadamente e com coerência às demais práticas sociais. Se não bastasse, pretendo sustentar que minha concepção é objetivamente melhor que a concepção elaborada por John Finnis. O que se percebe é que assim como a concepção de casamento de Finnis não pode ser plenamente apreendida sem uma prévia compreensão de suas ideias acerca dos bens humanos básicos, minha concepção de casamento é diretamente dependente de ideias como "conceitos interpretativos" e "objetividade" em questões de natureza moral. Logo, no presente capítulo, pretendo tratar destas categorias filosóficas que são fundamentais para a compreensão daquilo que entendo ser o casamento.

Meu aporte teórico para elucidar estas questões preliminares e substanciais, como mencionei, é Ronald Dworkin. Referido autor consegue explicar e avaliar a existência de divergências teóricas de um modo que a concepção finnisiana de casamento, por tratá-lo como um bem humano básico autoevidente, não é capaz. Na realidade, defenderei que a posição dworkiniana se mostra metodologicamente mais adequada para explicar o que se entende por casamento, enquanto Finnis assume uma postura dogmática que impossibilita o diálogo e a construção de uma concepção mais refinada e realista do matrimônio, no contexto de uma sociedade plural que passa por constantes transformações.

Desconheço obra em que Dworkin aborde de forma específica o conceito de casamento. Entretanto, em diversas passagens de seus livros e artigos, Dworkin afirma que o casamento deve ser visto como um conceito interpretativo, o que, dentre outras 
consequências, nos permite afirmar que o sentido do casamento só pode ser conhecido a partir dos valores que com ele se relacionam. Ocorre que a visão dworkiniana acerca do casamento limita-se a estes aspectos altamente abstratos - em sentido diverso de suas concepções de Direito, igualdade e justiça, as quais foram alvo de inúmeras e pormenorizadas análises de sua parte. Consequentemente, por questões metodológicas, assim como o capítulo antecedente centrou-se na concepção finnisiana de casamento, o presente capítulo irá abordar ideias centrais do pensamento dworkiniano que permitam afirmar que o casamento deva ser visto como um conceito interpretativo. Por fim, também pretendo estabelecer uma relação entre as concepções que Dworkin e Finnis possuem sobre o valor, antecipando a razão pela qual algumas críticas movidas por autores de orientação liberal, que serão vistas no próximo capítulo, não são capazes de atingir diretamente a posição finnisiana sobre o casamento - o que, na realidade, demonstra o caráter dogmático da posição de John Finnis sobre o casamento.

\subsection{A DISTINÇÃO ENTRE CONCEITO E CONCEPÇÃO}

O leitor provavelmente deve ter notado em diversas passagens deste trabalho a adoção das expressões "conceito" e "concepção". Quando afirmei que Finnis possui uma "concepção de casamento", o que esperei do leitor foi que entendesse essa afirmação no seguinte sentido: que Finnis tem uma compreensão particular do que seja o casamento, e que esta compreensão não é, obrigatoriamente, a mesma da minha ou de outras pessoas. Em outras palavras, trata-se da forma pela qual Finnis responde à questão "o que é casamento?", que pode ou não corresponder à forma pela qual outras pessoas responderiam a mesma questão. De qualquer sorte, deixei subentendida uma ideia que se tornou comum no pensamento filosófico e que faz referência à distinção existente entre tais expressões - a distinção entre conceito e concepção ${ }^{66}$.

\footnotetext{
${ }^{66}$ A relevância da distinção pode ser atribuída às observações de Walter Bryce Gallie, conforme se verifica em seu artigo Essentially contested concepts (GALLIE, 1956), apresentado em um encontro da Aristotelian Society de Londres. A ideia central de Gallie é de que os indivíduos discordam sobre o uso de determinados conceitos, como seria o caso de "arte", "democracia" e "tradição cristã". Se não bastasse, as pessoas defendem suas visões sobre o uso de tais conceitos através de argumentos, evidências e outras formas de justificação (GALLIE, 1956, p. 168). Stephen Guest (2010, p. 40) atribui à Gallie a “análise seminal da distinção entre conceitos e concepções". Segundo Guest (2010, p. 40), "Gallie argumenta que alguns conceitos, tais como a arte, a democracia, a justiça social e a 'vida cristã' são, por natureza, ideias que só podem ser entendidas como envolvendo argumento controvertido. Ele relaciona várias condições que são em parte descrições de qualquer conceito 'essencialmente contestado' e estas acarretam, penso, a ideia de que tais conceitos são entendidos por meio de diferentes concepções". Neste sentido, o conceito de "casamento" também encontra divergências quanto ao seu uso: Finnis acredita, argumentativamente, que o conceito de
} 
Tal distinção é central para a compreensão da teoria dworkiniana. Não se trata de uma ideia própria de Dworkin; outros autores, como Hart e Rawls, utilizam-na em suas respectivas obras ${ }^{67}$. Entretanto, acredito que Dworkin apresenta de forma clara a distinção, razão pela qual optei por analisá-la neste capítulo sem prejuízo do seu uso implícito nos momentos anteriores do trabalho. Primeiramente, creio ser interessante apresentar a maneira com que compreendo tal distinção.

A meu ver, a ideia central é de que indivíduos compartilham ideias gerais acerca de determinadas coisas, objetos, valores etc. Quando afirmo, por exemplo, que certa decisão foi justa, as pessoas entendem o que quero dizer, e principalmente entendem o que não quero dizer - certamente, não se trata de considerações sobre o que almocei no dia anterior. Há, neste sentido, uma unidade de compreensão acerca do que é justiça. Isso decorre do compartilhamento de determinadas ideias que, ainda que em alto grau de abstração, nos permite afirmar que compartilhamos um conceito - no caso, “justiça”.

Ocorre que podemos discordar quanto ao uso e significado de um conceito em determinadas circunstâncias. Alguém poderá sustentar que a decisão que afirmei ser justa é, na realidade, injusta. Ainda que esta pessoa entenda o significado da minha afirmação, ela discorda quanto ao uso do conceito de justiça. Isso ocorre porque a ideia que esta pessoa tem acerca dos usos ou significados do conceito de justiça é, em determinados aspectos, distinta da minha. Ela possui uma concepção diferente do conceito de justiça. Mesmo assim, nossas concepções compartilham determinados aspectos em comum que correspondem às ideias ou paradigmas centrais de justiça (o conceito de justiça), que nos permitem afirmar que estamos falando da mesma coisa e não de coisas diferentes - o que também nos permite dizer que, se fosse outra a decisão em questão, eventualmente concordaríamos quanto à sua justiça ou injustiça ${ }^{68}$.

casamento está restrito às uniões heterossexuais e representa um bem humano básico onde, além da amizade entre os cônjuges, há a prática de atos de tipo reprodutivo. Outros defenderão que o uso do conceito de casamento não se restringe aos casais heterossexuais, mas pode abranger a união entre pessoas do mesmo sexo, fornecendo justificativas para tanto.

${ }^{67}$ Neste sentido, podemos afirmar que $O$ conceito de direito, de Hart, corresponde à "concepção" hartiana do Direito (GUEST, 2010, p. 41). Já Uma teoria da justiça, de Rawls, expõe a "concepção" rawlsiana sobre o que é justiça. Rawls, neste sentido, é explícito: "Assim, parece natural pensar no conceito de justiça como sendo distinto das várias concepções de justiça e como sendo especificado pelo papel que estes diferentes conjuntos de princípios, essas diferentes concepções, têm em comum. Desse modo, os que defendem outras concepções de justiça podem ainda assim concordar que as instituições são justas quando não se fazem distinções arbitrárias entre as pessoas na atribuição de direitos e deveres básicos e quando as regras determinam um equilíbrio adequado entre reivindicações concorrentes das vantagens da vida social" (RAWLS, 2002, p. 6).

68 Stephen Guest também apresenta sua "ideia central" sobre a distinção entre conceito e concepção, nos seguintes termos: "A ideia é esta. As pessoas podem ter concepções diferentes de alguma coisa e podem discutir umas com as outras, e muitas vezes discutem, sobre qual concepção é a melhor. Você observará a 
É desta maneira que entendo a distinção entre conceito e concepção, o que se reflete na forma com que adoto os vocábulos ao longo do trabalho. Atribuo tal compreensão à interpretação que fiz acerca da forma com que Dworkin concebe a distinção em sua obra Law's Empire (1986). É possível perceber, também, certa semelhança com a análise previamente empreendida sobre as ideias de significado focal, casos centrais e casos periféricos constantes na teoria de John Finnis.

Buscando explicar o que entende por conceitos de tipo interpretativo (cujos pormenores explicitarei no próximo tópico), Dworkin nos convida a refletir sobre uma sociedade imaginária, cujos membros seguem um conjunto de regras que denominam "regras de cortesia" (DWORKIN, 1986, p. 47). Tais regras, a princípio, assemelham-se a "tabus" e são aceitas e aplicadas sem maiores questionamentos. Mas com o passar do tempo a compreensão que as pessoas têm sobre tais regras vai se modificando. Para Dworkin (1986, p. 47), esta sociedade imaginária desenvolve uma "atitude interpretativa" diante destas regras de cortesia, atitude esta que possui dois componentes. Em primeiro lugar, os indivíduos percebem que as regras de cortesia não somente existem, mas que possuem um propósito ou valor. Por outro lado, ao perceberem que a cortesia envolve um propósito ou valor, os indivíduos da sociedade imaginária compreendem que a aplicação de tais regras é sensível e limitada a este mesmo propósito que a cortesia busca efetivar em outras palavras, a "instituição da cortesia" deixa de ser mecânica, e as pessoas agora buscam impor um sentido para esta instituição, reestruturando-a à luz deste sentido (DWORKIN, 1986, p. 47).

Ocorre que as pessoas passam a divergir quanto ao sentido e propósito da cortesia. Assim, por exemplo, se no princípio a cortesia era compreendida como uma questão de respeito a indivíduos "socialmente superiores", pode passar a ser entendida como deferência a pessoas mais velhas, ou a mulheres, e assim adiante (DWORKIN, 1986, p. 48). Observada a divergência acerca dos propósitos da cortesia, Dworkin busca desvendar se é possível elaborar uma teoria mais conceitual acerca da sua natureza - o que corresponderia a responder à questão “o que é cortesia?”. Dworkin constata que, em que pese as mudanças na compreensão da cortesia ao longo das gerações na sociedade

evidente analogia com as interpretações rivais de uma 'coisa'. No contexto das concepções, esta 'coisa' é o 'conceito' e é constituída por um nível de abstração a respeito do qual há uma concordância quanto a um conjunto distinto de ideias, e que é empregada em todas as interpretações. Uma concepção, por outro lado, incorporará certa controvérsia que, segundo Dworkin, encontra-se 'latente' no conceito” (GUEST, 2010, p. 39). 
imaginária, as diferentes práticas que daí surgiram têm em comum o fato de serem todas versões de cortesia (DWORKIN, 1986, p. 69).

A partir daí, Dworkin sugere que os debates acerca da cortesia na sociedade imaginária terão uma estrutura semelhante à de uma árvore. As pessoas podem concordar, por exemplo, que a cortesia é uma questão de respeito (uma afirmação abstrata que constituiria o "tronco da árvore"), mas poderão discordar sobre o que está sendo considerado nesta ideia de respeito (subinterpretações acerca da ideia mais geral e abstrata de que cortesia é uma questão de respeito, o que corresponderia aos "galhos da árvore"). Logo, nas palavras de Dworkin (1986, p. 70, tradução livre):

\begin{abstract}
Pessoas em geral concordam sobre as proposições mais gerais e abstratas sobre a cortesia, que formam o tronco da árvore, mas discordam sobre refinamentos concretos ou subinterpretações sobre estas proposições abstratas, sobre os galhos da árvore. Por exemplo, em um certo estágio de desenvolvimento da prática, todos concordam que a cortesia, descrita mais abstratamente, é uma questão de respeito. Mas há uma divisão maior sobre a correta interpretação da ideia de respeito. Uma parte pensa que o respeito, propriamente entendido, deve ser demonstrado para pessoas de uma categoria ou grupo, mais ou menos automaticamente, enquanto a outra pensa que o respeito deve ser merecido de pessoa por pessoa.
\end{abstract}

Diante desta estrutura, o interessado em analisar a natureza da cortesia poderá isolar uma conexão "conceptual" entre cortesia e respeito. Enquanto o respeito, para a comunidade imaginária, corresponderia ao conceito de cortesia, as diferentes posições sobre o que o respeito verdadeiramente demanda correspondem a concepções sobre o conceito (DWORKIN, 1986, p. 71). Consequentemente, o contraste entre conceito e concepção passa a ser um contraste entre diferentes níveis pela qual a interpretação da prática da cortesia pode ser estudada:

\footnotetext{
O contraste entre conceito e concepção é, aqui, um contraste entre níveis de abstração nas quais a interpretação da prática pode ser estudada. Em um primeiro nível a concordância se reúne ao redor de ideias discretas que são aplicadas sem controvérsia em todas as interpretações; em um segundo, a controvérsia latente nesta abstração é identificada e retomada. Expor esta estrutura pode ajudar a aguçar o argumento e irá, em qualquer caso, melhorar a compreensão da comunidade sobre seu meio intelectual (DWORKIN, 1986, p. 71, tradução livre).
}

Não se deve esquecer que, para Dworkin, na medida em que muitas práticas sociais poderão ter por referência propósitos e valores (como é o caso da cortesia), é possível identificar uma concepção que melhor explique a relação entre tais práticas e os valores que se lhes atribuem. Em outras palavras, Dworkin assevera a possibilidade de, entre 
diferentes concepções, uma possa ser considerada melhor ou pior que outra. Tal ponto envolve a questão da objetividade na interpretação, que será analisada mais adiante.

Para os fins deste tópico, o importante é observar que o casamento, de forma semelhante à cortesia, corresponde a um conceito que admite inúmeras concepções. Somos capazes de entender quando alguém afirma que é casado, e o que isso significa em termos gerais e abstratos - entenderemos, por exemplo, que este indivíduo partilha uma vida em comum com outra pessoa. Entretanto, na medida em que refinamos nosso entendimento sobre o conceito de casamento (ou seja, quando desenvolvemos uma concepção de casamento), poderemos ou não divergir quanto ao seu uso diante das mais variadas circunstâncias. Se considerarmos, assim como Finnis, que a diversidade de gêneros é um elemento relevante para a compreensão conceitual (i.e., da "essência") de casamento, entenderemos que duas mulheres ou dois homens jamais poderão se casar. Por outro lado, se nossa concepção de casamento envolve a compreensão de que o matrimônio diz respeito a valores completamente independentes do gênero dos indivíduos, é possível ver a união entre homossexuais como categoria conceitualmente abrangida pelo casamento.

\subsection{TIPOS DE CONCEITOS}

Considerando os diferentes contextos e propósitos dos indivíduos, percebemos que nem sempre utilizamos os conceitos da mesma forma ${ }^{69}$. Neste sentido, Dworkin faz uma divisão entra as maneiras através das quais podemos analisar conceitos: criterial, natural ou interpretativa. Tais categorias não são estanques: para determinados propósitos, uma definição criterial de um conceito pode ser mais conveniente; entretanto, para outros fins, uma abordagem interpretativa poderá ser mais adequada.

Creio que esta "tipologia conceitual" elaborada por Dworkin é apresentada com maior clareza analítica na introdução e no artigo Hart's Postscript and the Point of Political Philosophy, constantes na obra Justice in Robes (DWORKIN, 2006b), bem como no oitavo capítulo de seu último livro, Justice for Hedgehogs (DWORKIN, 2011). Basearme-ei na tipologia apresentada nestas obras com o intuito de demonstrar que, para entendermos o que significa o casamento, devemos analisá-lo de modo interpretativo.

\footnotetext{
69 Ao tratar do conceito de Direito, Dworkin (2006b, p. 9) afirma: “concepts can be put to very different kinds of uses, and our theory of any concepts of law must be sensitive to the role we are supposing it to play".
} 


\subsubsection{Conceitos criteriais}

O primeiro tipo de conceitos que Dworkin analisa são os conceitos criteriais. Para ele, as pessoas compartilham determinados conceitos apenas quando concordam com uma definição que, de forma grosseira ou precisa, estabelece os critérios para a correta aplicação do termo ou frase em questão (DWORKIN, 2006b, p. 9). Assim, por exemplo, compartilhamos o conceito de triângulo equilátero porque entendemos que o critério relevante para a compreensão deste conceito é se tratar de uma figura geométrica que tenha três lados iguais. Trata-se, no caso, de um critério preciso (DWORKIN, 2006b, p. 9).

Entretanto, nem todos os conceitos deste tipo são pautados em critérios tão precisos como no caso de figuras geométricas. A calvície pode ser vista como um conceito criterial, mas os critérios que efetivamente determinam quando alguém é ou não é considerado calvo não são precisos (DWORKIN, 2011, p. 158). Afinal, quantos fios de cabelo um indivíduo deve ter para não ser considerado calvo? De forma semelhante, quando buscamos uma definição sociológica do conceito de Direito podemos nos valer de inúmeros critérios, como a existência de um conjunto de normas que estabelecem sanções, em um dado sistema jurídico, ou ainda a divisão do exercício do poder em esferas legislativa, executiva, judiciária etc.

O relevante, segundo Dworkin, é que teorias que tratam certos conceitos de forma criterial o fazem através da estipulação de uma definição mais precisa do conceito, tendo em vista determinados propósitos. Em suas palavras, "desenvolver uma teoria deste tipo de conceito significa propor uma definição mais precisa para algum propósito em particular” (DWORKIN, 2006b, p. 9, tradução livre). Isso não significa, consequentemente, que a definição "criterial" mais ou menos precisa de um conceito captura melhor sua essência (DWORKIN, 2006b, p. 9). O que acontece é que, para determinados propósitos, uma definição possa ser mais ou menos conveniente.

O casamento poderá ser tratado, em muitas hipóteses, como um conceito criterial. Suponhamos que um sociólogo esteja interessado em descobrir a média de casamentos realizados por mês, no sudeste brasileiro, ao longo de um ano. Para este fim, ele poderá estabelecer que por casamentos entendem-se apenas as uniões entre homem e mulher celebradas perante o cartório competente. Mas ele poderia estabelecer outros critérios: poderia identificar o casamento a partir da maneira com que as pessoas veem seus relacionamentos (identificando-se como casadas), ou ainda levando em consideração o vínculo matrimonial celebrado perante uma autoridade religiosa. Em nenhuma das 
hipóteses, entretanto, o sociólogo está respondendo à questão da natureza ou essência do casamento $^{70}$, pois isso não pode ser "estipulado" ou "definido" através de "critérios". Não é por outra razão que Dworkin (2006b, p. 9/10, tradução livre) afirma: “'́́ um erro dizer, por exemplo, como muitos atualmente dizem, que a essência do casamento é a união entre homem e mulher, de forma que o 'casamento gay' é um oxímoro'.

\subsubsection{Conceitos de tipo natural}

O segundo tipo de conceitos que Dworkin analisa são os conceitos que denomina de “tipo natural". Para Dworkin (2006b, p. 10, tradução livre), "pessoas compartilham alguns conceitos cujos exemplos possuem uma estrutura física natural ou biológica metais e animais, por exemplo, mesmo quando elas não concordam sobre a natureza essencial dos exemplos ou nos critérios que utilizam para identificá-los”.

Neste sentido, podemos identificar substâncias e minerais a partir de sua composição química, e animais a partir da estrutura do seu DNA. O interessante é que as pessoas podem se referir ao mesmo conceito de tipo natural ainda que, conscientemente, utilizem diferentes critérios para identificar seus exemplos (DWORKIN, 2011, p. 159). Vamos supor que estamos diante de um animal e que divergimos quanto à sua identificação. Para mim, o animal em questão é um filhote de leão, dado seu porte e os pelos de coloração bege. Para você, corresponde a um simples gato angorá, uma vez que mia tal qual um gato comum. Em qualquer das hipóteses, eu e você concordamos que "leão" e "gato angorá" denominam diferentes animais, com composições biológicas distintas. Na hipótese de compreendermos o que é esta composição biológica distinta (por exemplo, o DNA), e ficar comprovado que o animal em questão possui DNA de um gato angorá, o melhor é que eu reveja minha opinião e reconheça que o animal em questão não é um filhote de leão, e sim um gato angorá ${ }^{71}$.

\footnotetext{
70 Dworkin também afirma que o casamento é um conceito criterial "moderadamente impreciso". Em suas palavras, "The concept of marriage is a moderately imprecise criterial concept: we call many different forms of legal and social arrangements found in different societies as marriages" (DWORKIN, 2006b, p. 9)

${ }^{71} \mathrm{O}$ exemplo em questão corresponde a uma adaptação de exemplo muito semelhante utilizado por Dworkin em seu último livro, Justice for Hedgehogs (2011). O caso dworkiniano é o seguinte: "You and I disagree, say, about whether an animal we encounter in Piccadilly is a lion, and it turns out that I identify lions by their size and shape and you only by what you believe to be their distinctive behavior. I say the animal we have met is a lion because it looks like a lion, and you deny this because instead of roaring it speaks an accented English. [...] You and I assume that 'lion' names a distinct biological kind and that the beast we met is a lion if it has a lion's biological essence, whatever that is, whether or not it meets the criteria either of us normally uses to identify lions. If you understand DNA, and if tests showed that the creature we saw
} 
O importante é perceber que conceitos criteriais e conceitos de tipo natural possuem algo importante em comum: em ambos os casos, aceitamos um "teste decisivo" (uma espécie de procedimento decisório) que nos permite identificar e aplicar um conceito (DWORKIN, 2011, p. 160). Não compartilharíamos o conceito de triângulo equilátero se lhe atribuíssemos outros critérios, além de ser uma figura geométrica com três lados iguais. De maneira semelhante, não compartilharíamos o conceito de leão se discordássemos acerca do DNA de um determinado animal, mesmo quando concordamos que ele pertenceu ou não pertenceu à espécie historicamente designada como "leões" (DWORKIN, 2011, p. 160).

A distinção entre conceitos criteriais e de tipo natural é, como se percebe, bastante sutil. O relevante é que "tipos naturais" correspondem àquelas coisas que possuem uma identidade fixada na natureza (como no já mencionado caso das composições químicas e das espécies de animais), e as pessoas compartilham um conceito de tipo natural quando utilizam este conceito para se referir ao mesmo "tipo natural" (DWORKIN, 2011, p. 159).

Como se pode observar, não faz sentido tratar o casamento como um conceito de tipo natural. O casamento não possui um DNA. De qualquer forma, alguém poderia listar os diferentes tipos de arranjos sociais ou jurídicos ao longo dos séculos que agora poderíamos descrever como exemplos de "casamento", com o intuito de descobrir quais são os seus "elementos essenciais". Ainda assim, este empreendimento seria inútil na medida em que dependeríamos de uma justificativa para explicar o que torna um elemento essencial para a configuração de casamento e outro como meramente contingente, não sendo o bastante recorrer a dados meramente estatísticos para justificar, por exemplo, porque homossexuais não possam se casar (enquanto questão conceitual) (DWORKIN, 2006b, p. 152/153). Como questiona Dworkin (2006b, p. 153), “não seria loucura supor que estas questões sobre a própria natureza do casamento pudessem ser resolvidas ao observarmos uma lista que compilamos, não importa o quão longa ela seja?"

\subsubsection{Conceitos interpretativos}

O último tipo de conceitos analisado por Dworkin, e particularmente central em toda sua teoria, corresponde aos conceitos interpretativos.

had the DNA of a lion, you would likely change your opinion to recognize talking lions (DWORKIN, 2011, p. 159) 
Segundo Dworkin (2006b, p. 10), alguns dos conceitos que compartilhamos não funcionam de forma criterial e nem são de tipo natural: funcionam como conceitos interpretativos que nos encorajam a refletir e contestar o que demanda algumas das práticas sociais que construímos. O elemento central neste tipo de conceito corresponde à atribuição de um valor ou propósito à prática social compartilhada. Se não bastasse, nós formamos visões sobre as condições de verdade acerca das reivindicações particulares que as pessoas fazem dentro desta prática, à luz dos propósitos e valores que atribuímos (DWORKIN, 2006b, p. 12).

É interessante ressaltar que tal tipo conceitual tem particular relevância para a compreensão daquilo que Dworkin denomina sentido doutrinal de um conceito. Assim, por exemplo, nós exploramos o sentido doutrinal de "Direito" tendo em vista seus efeitos particulares, dentro de um contexto que demanda a ideia de verdadeiro/falso. Afirmar que para o direito de Rhode Island um contrato assinado por alguém com menos de doze anos é inválido corresponderia a uma afirmação em sentido doutrinal (DWORKIN, 2006b, p. 2). De qualquer sorte, notadamente no caso do Direito, o seu sentido doutrinal está diretamente ligado à busca pelas condições de verdade das proposições morais e jurídicas (DWORKIN, 2006b, p. 5) ${ }^{72}$. Tal ponto é relevante na medida em que o casamento também pode ser analisado em um sentido doutrinal: a proposição de que o casamento só possa ocorrer (conceitualmente) entre homem e mulher pode ser analisada à luz das condições de verdade desta proposição (se esta afirmação é certa ou errada, e sob quais fundamentos). Ainda, concebê-la como verdadeira implica na constatação de inúmeros efeitos particulares: se uma eventual união entre duas mulheres ou dois homens não for considerada um casamento, então aos indivíduos envolvidos nesta união não serão reconhecidos eventuais direitos e garantias que o entendimento socialmente compartilhado e o Direito atribuem à instituição do matrimônio.

\footnotetext{
72 O sentido doutrinal se diferencia dos sentidos sociológico, taxonômico e aspiracional. O sentido sociológico aproxima-se da ideia de conceitos criteriais, uma vez que faz referência a testes para a identificação do Direito em determinadas sociedades, com diferentes tipos de estrutura institucional - como seria a posição weberiana de que não existiria Direito onde não há instituições especializadas para o exercício da coerção (DWORKIN, 2006b, p. 3). O sentido taxonômico tem por finalidade diferenciar padrões que consideramos jurídicos de padrões morais ou costumeiros, como se padrões jurídicos representassem um conjunto de padrões que pudessem ser individuados e contabilizados - ou, melhor dizendo, como se pudessem ser "rotulados" como Direito, o que para Dworkin não corresponde a um empreendimento interessante (DWORKIN, 2006b, p. 4/5). Por fim, o sentido aspiracional diz respeito aos ideais que associamos ao Direito, como é o caso frequente dos ideais de legalidade ou "Estado de Direito" (rule of law), e em si é um conceito contestado - nós concordamos sobre os ideais que o Direito visa assegurar, mas discordamos sobre quais são as melhores formulações de tais ideais (DWORKIN, 2006b, p. 6).
} 
Tratarei da ideia do casamento enquanto conceito interpretativo mais adiante. Por hora, outro conceito que pode elucidar com maior clareza a ideia central deste tópico é o conceito de justiça, que corresponde claramente a um conceito interpretativo. Nós concordamos com casos e ideias paradigmáticas que formam este conceito, mas discordamos sobre o que torna um ato justo ou injusto (DWORKIN, 2011, p. 160/161) possuímos concepções diferentes de justiça. Neste sentido, a distinção previamente analisada entre conceito e concepção é particularmente importante para a compreensão dos conceitos interpretativos. Ela reflete o fato de que o tipo de concordância que deve existir para que seja possível o compartilhamento de um conceito interpretativo é diferente da concordância existente quando compartilhamos conceitos criteriais ou de tipo natural: a concordância necessária para a existência de um conceito interpretativo não corresponde a um "procedimento decisório" ou a um "teste decisivo" que permita a identificação de exemplos. Ao contrário, como visto, o fato de compartilharmos um conceito interpretativo é consistente com as significativas (e muitas vezes intratáveis) diferenças de opinião acerca dos casos emblemáticos de conceitos interpretativos (DWORKIN, 2011, p. 161).

A concordância que norteia os conceitos interpretativos relaciona-se diretamente com os casos paradigmáticos que formam estes conceitos. Com relação ao conceito de justiça, em que pese significativas discordâncias em outros casos, concordamos que seria uma prática injusta condenar e punir alguém sabidamente inocente (DWORKIN, 2011, p. 161). Podemos afirmar que a condenação de inocentes corresponde a um caso paradigmático de injustiça, e é a partir de casos como este que vamos interpretando e formando nossa compreensão sobre vários conceitos interpretativos.

Certamente, como afirma Dworkin (2011, p. 161, tradução livre), “nós não podemos dizer apenas quanto ou quais detalhes de concordância sobre paradigmas é necessário em uma comunidade em particular para justificar o tratamento de um conceito como interpretativo para esta comunidade”. Em outras palavras, não há como determinar de forma certa e inequívoca a concordância sobre casos paradigmáticos para descobrir se o conceito, em dada comunidade, é visto como interpretativo. Como Dworkin sustenta, a interpretação é interpretativa desde o princípio ( "interpretation is interpretive all the way down”); mesmo os casos paradigmáticos, que fundamentam a interpretação dos conceitos interpretativos, são objeto de interpretação. Este ponto merece ser analisado com maior vagar, pois versa sobre questões peculiares do pensamento dworkiniano que podem gerar inúmeros equívocos. Tratar de conceitos interpretativos depende de uma compreensão sobre o que é interpretação para Dworkin. 
Antes, porém, é importante relembrar um último ponto que eventualmente possa passar despercebido. De fato, muitas vezes Dworkin fala expressamente em conceitos de "tipo" criterial, natural ou interpretativo, dando a entender, por exemplo, que um conceito "é" criterial e que consequentemente "não é" interpretativo. Mas não há como "engavetar" os conceitos desta forma. Eles podem, dependendo do contexto e dos fins pretendidos, serem analisados por uma perspectiva criterial, natural ou interpretativa. É por isso que falo no casamento enquanto um conceito interpretativo, pois, como visto, ele pode ser concebido de forma criteral a depender dos interesses de quem usa este conceito (e.g. o mencionado caso do sociólogo $)^{73}$.

\subsubsection{O que é interpretação para Dworkin?}

Como sustenta Stephen Guest (2010, p. 28), a ideia de interpretação em Dworkin está diretamente relacionada à noção de que alguns conceitos não podem ser plenamente compreendidos a não ser de maneira interpretativa. Trata-se de "conceitos que precisam ser investidos de algum significado que uma simples descrição não pode fornecer" (GUEST, 2010, p. 28). Por tal razão, considero ser metodologicamente mais adequado tratar do tema da interpretação conjuntamente com a ideia de conceitos interpretativos.

Talvez a melhor forma de se compreender a concepção dworkiniana de interpretação esteja na análise do texto De que maneira o direito se assemelha à literatura, presente na obra Uma questão de princípio (DWORKIN, 2005, p. 217-249), como sugere Ronaldo Porto Macedo Jr. (2010, p. 5). Neste texto, Dworkin (2005, p. 217) sustenta que "podemos melhorar nossa compreensão do Direito comparando a interpretação jurídica com a interpretação em outros campos do conhecimento, especialmente a literatura”.

Sua primeira constatação é de que as proposições de Direito não são apenas descritivas (basta analisar, por exemplo, as discordâncias entre juristas quanto ao sentido e veracidade de proposições jurídicas (e.g., se determinado esquema de ação afirmativa é ou

\footnotetext{
73 Tal fato não passa despercebido por Dworkin. Para ele, é possível que conceitos possam "migrar" a depender do contexto em que são usados: "Because the assignment of any particular concept to one of the types we have distinguished is an interpretive conclusion, it need not hold for al uses of what seems the same concept. In most circumstances it would be bizarre to treat the concept of a book as other than a criterial concept. (...) Imagine a statute declaring that bald men are entitled to a special income tax exemption. This silly statute would convert the question of baldness into a genuine interpretive issue: officials, lawyers, and judges would have to contrive some highly artificial definition of baldness (not necessarily a hair-counting definition) by asking which such definition would make most political sense of the exemption. Less silly examples are more plausible: a statute exempting books from sales or value-added tax but leaving 'book' undefined, for instance. Concepts that are normally criterial often become interpretive when embedded in law in that way" (DWORKIN, 2011, p. 164-165).
} 
não constitucionalmente válido), mas também não se resumem apenas a expressões sobre o que o indivíduo deseja que o Direito seja (quando alguém afirma que o plano de ação afirmativa é válido, pretende descrever o Direito como ele é, e não como deveria ser) (DWORKIN, 2005, p. 218/219). Logo, as proposições jurídicas não correspondem apenas a descrições ou valorações. Tais proposições "são interpretativas da história jurídica, que combina elementos tanto da descrição quanto da valoração, sendo porém diferente de ambas" (DWORKIN, 2005, p. 219).

Para poder explicitar melhor sua afirmação, Dworkin traça uma analogia entre a interpretação jurídica e a interpretação literária. Abordando esta última, sugere que a interpretação de uma obra literária tenta mostrar que maneira de ler o texto revela-o como "a melhor obra de arte", denominando sua sugestão de hipótese estética (DWORKIN, 2005, p. 222). Certamente, não se trata de transformar esta obra de arte em outra obra de arte, que seja "melhor": existem limitações à interpretação, e a interpretação de um texto, para Dworkin (2005, p. 223) busca mostrá-lo como a melhor obra de arte que ele pode ser.

Uma primeira limitação à tarefa do interprete corresponde às questões de identidade: os termos de um texto devem ser levados em consideração e não podem ser alterados com o fim de torná-lo uma obra de arte melhor (DWORKIN, 2005, p. 223). Assim, se nossa leitura de um texto envolve o acréscimo ou supressão de parágrafos, não estamos propriamente "interpretando", mas sim alterando um texto e criando uma nova obra.

Outra limitação diz respeito à coerência ou integridade na arte (DWORKIN, 2005, p. 223). O intérprete deve ser sensível, por exemplo, às questões de estilo e gênero na literatura. Mesmo que ele considere que um romance filosófico seja mais valioso que uma história de mistério, isso não significa que um romance da Agatha Christie corresponda a um tratado sobre o significado da morte (DWORKIN, 2005, p. 223/224). Consequentemente,

\footnotetext{
Essa interpretação falha não apenas porque um livro de Agatha Christie, considerado como um tratado sobre a morte, seja um tratado pobre, menos valioso que um bom texto de mistério, mas porque a interpretação faz do romance um desastre. Todas as frases, exceto uma ou duas, seriam irrelevantes para o tema suposto, e a organização, o estilo e as figuras seriam adequadas não a um romance filosófico, mas a um gênero inteiramente diferente (DWORKIN, 2005, p. 224).
}

Mas mesmo os intérpretes podem divergir com relação às questões de identidade $\mathrm{e}$ coerência. Eles possuem diferentes teorias sobre o que é arte e quais são seus propósitos 
(DWORKIN, 2005, p. 226). Podem divergir, mais ainda, com relação à própria hipótese estética: afinal, o que determinaria que uma leitura é melhor que outra? Se até mesmo grandes críticos literários possuem opiniões tão divergentes sobre um mesmo texto, que sentido faz em se buscar o "melhor" sentido que uma obra possa ter? Em síntese, onde se insere a objetividade na interpretação?

\title{
2.2.3.2. Objetividade na interpretação
}

A objetividade na atividade de interpretação e entre valores de ordem moral corresponde a um dos temas mais debatidos no contexto filosófico. E, sem dúvida alguma, uns dos mais complexos e difíceis de serem analisados.

Creio que a posição dworkiniana a respeito do tema busca mais responder às críticas existentes à sua concepção de verdade na interpretação do que, particularmente, algo que Dworkin considere essencialmente relevante de ser explicado do ponto de vista filosófico $^{74}$. Neste sentido, Dworkin sustenta, em seu texto Interpretação e objetividade, também constante na obra Uma questão de princípio (2005, p. 251-266), que seu interesse pelo problema da objetividade é inteiramente negativo (DWORKIN, 2005, p. 257). Em suas palavras,

\begin{abstract}
Não vejo por que tentar encontrar algum argumento geral no sentido que os julgamentos interpretativos morais, políticos, jurídicos ou estéticos são objetivos. Os que pedem algum argumento dessa natureza querem algo diferente do tipo de argumentos que eu e eles produziríamos a favor de exemplos ou casos particulares de tais julgamentos. Mas não vejo como poderiam existir tais argumentos diferentes. Não tenho nada a favor da objetividade dos julgamentos morais, a não ser argumentos morais, nada a favor da objetividade dos julgamentos interpretativos, a não ser argumentos interpretativos, e assim por diante (DWORKIN, 2005, p. 257).
\end{abstract}

Consequentemente, é possível imaginar uma pessoa que acredita que a escravidão seja injusta e que, questionada sobre seu ponto de vista, formulará diversos argumentos. Todavia, sendo tais argumentos contestados, em última análise a pessoa deveria se sustentar em suas próprias convicções. Logo, afirmar que a escravidão é objetivamente ou

\footnotetext{
${ }^{74}$ Em sentido semelhante, Stephen Guest (2010, p. 141) afirma: "Um comentário preliminar é exigido. O trabalho de Dworkin quanto à objetividade é defensivo. (Ele gostaria de seguir adiante com argumentos sobre, por exemplo, se é verdade que abortos são moralmente pervertidos, e não questões tidas por independentes, como 'o que vale como verdade nesta área'). Não é, portanto, contraditório para ele negar a tese de 'nenhuma resposta certa' e assim permitir algumas situações em que não haja uma resposta certa. Ademais, não há nada na lógica que previna a posição de que a tese da resposta certa é que não haja resposta certa”.
} 
realmente injusta não equivaleria a uma asserção adicional, mas sim a uma maneira mais enfática de se sustentar a injustiça da escravidão (DWORKIN, 2005, p. 258) ${ }^{75}$. Entretanto,

\begin{abstract}
[...] não posso voltar as costas ao problema da objetividade como gostaria, e o ensaio de Fish mostra por que não. Pessoas como Fish dizem que existe algo radicalmente errado com o que eu e os outros pensamos a respeito do Direito, da moralidade e da literatura. Nossos argumentos supõe, segundo dizem, que os julgamentos feitos nesses âmbitos podem ser objetivamente certos ou errados, mas que, na verdade, não podem (...) Ao negar que a escravidão possa ser real ou objetivamente injusta, um filósofo moral não quer que o compreendam como se estivesse sustentando a mesma posição de um fascista que argumenta não haver nada errado na escravidão. Ele insiste em que seus argumentos não são morais, mas argumentos filosóficos de natureza muito diferente, aos quais devo responder de maneira muito diferente (DWORKIN, 2005, p. 259).
\end{abstract}

O que Dworkin sugere é que estes filósofos trabalham com uma distinção típica das demais ciências naturais: nós poderíamos estabelecer uma distinção entre, por exemplo, afirmações propriamente matemáticas (que são internas ao domínio da Matemática), e entre questões sobre a prática da Matemática (que lhe seriam externas) ${ }^{76}$. De forma semelhante, seria possível estabelecer uma distinção entre questões de primeira-ordem ou substantivas e questões de segunda-ordem ou meta-éticas no plano moral: "A afirmação de que torturar bebês é imoral é uma afirmação de primeira-ordem, substantiva; a hipótese de que esta opinião é quase universalmente sustentada é uma afirmação de segunda ordem ou meta-afirmação” (DWORKIN, 2011, p. 31, tradução livre).

Estes filósofos sustentariam, portanto, que existe uma diferença substancial entre as opiniões pessoais (“a escravidão é errada") e a "confirmação" destas opiniões enquanto questões de "verdade" ("a escravidão é objetivamente ou verdadeiramente errada"), o que seria feito apenas com recurso a um plano externo da moral. Se não bastasse, a maior parte de tais filósofos compreende que inexistiria esta "verdade objetiva", ou que as questões de segunda-ordem só poderiam ser respondidas (se é que poderiam) em um plano metafísico.

\footnotetext{
75 Ainda, segundo Dworkin (2005, p. 258): “É claro que alguém poderia estipular um sentido para a palavra 'objetivamente' que tornaria a proposição 'adicional' realmente diferente. Poderia dizer que a questão adicional, sobre se a escravidão é objetivamente injusta, indaga se todos concordam que sim, por exemplo, ou se concordariam em condições favoráveis à reflexão. Nesse caso, diria que não acredito que a escravidão seja objetivamente injusta. Mas isso não afeta nem ressalvaria, de maneira nenhuma, meu julgamento original, de que a escravidão é injusta. Nunca pensei que todos concordavam ou concordariam". Esta maneira de conceber a ideia de objetividade na moral (enquanto forma mais enfática de apresentar nossas visões morais) também se assimilaria àquilo que Dworkin (2011, p. 27) denomina visão "comum" ou "habitual" ("ordinary" view): "You probably think, that is, that the truth of your moral convictions does not depend on what anyone thinks or feels. You might say, to make plain that that is what you think, that torturing babies for fun is 'really' or 'objectively' wicked. This attitude toward moral truth - that at least some moral opinions are objectively truth in this way - is very common. I shall call it the 'ordinary' view'.

76 "The question whether Fermat's theorem has at last been proved is an internal question of mathematics; the question whether a higher percentage of students study calculus now than formerly is an external question about mathematics" (DWORKIN, 2011, p. 31).
} 


\title{
Trata-se de uma posição denominada por Dworkin de ceticismo externo ou arquimediano $^{77}$.
}

Dworkin sustenta, entretanto, que tais filósofos se prendem a um mero e ilusório “jogo de linguagem”. Em sua visão, estas posições

\begin{abstract}
Supõe que podemos distinguir estes dois tipos diferentes de afirmações da maneira como distinguimos afirmações sobre Roger Ackroyd como personagem de um romance de afirmações sobre Roger Ackroyd como personagem histórico. $\mathrm{E}$ isso é exatamente o que não podemos fazer, porque as palavras "objetivamente" e "realmente" não podem mudar o sentido de julgamentos morais ou interpretativos. Se julgamentos morais, estéticos ou interpretativos têm o sentido e a força que têm só porque figuram em um empreendimento humano coletivo, então tais julgamentos não podem ter um sentido "real" e um valor de verdade "real" que transcenda esse empreendimento e, de alguma maneira, apodere-se do mundo "real" (DWORKIN, 2005, p. 262).
\end{abstract}

Consequentemente, a ideia de que existem dois pontos de vista, de que podem ser levantados argumentos substantivos em práticas sociais e argumentos céticos sobre práticas sociais, seria inadequada. Logo, o ceticismo externo é, em essência, impossível (DWORKIN, 2005, p. 262/263). Nas palavras de Dworkin (2005, p. 263):

\begin{abstract}
O ceticismo corre o risco de tornar-se impossível porque se nega, ao que parece, que alguém possa criticar a moralidade, por exemplo, sem assumir o ponto de vista moral. O ceticismo, por essa descrição, anularia a si próprio, pois se o cético precisa produzir argumentos morais para contestar a moralidade, deve
\end{abstract}

77 Em um artigo de alta complexidade teórica, intitulado Objectivity and Truth: You'd Better Believe It, Dworkin (1996) afirma que é possível dividir o ceticismo em duas modalidades centrais. A primeira modalidade de postura cética é aquela que Dworkin denomina de ceticismo externo ou arquimediano, que correspondente ao caso que ora apresento. Tal ceticismo é "externo" à moral, pois se mantém além de um conjunto de crenças morais e as julga a partir de premissas e atitudes que com ela não se relacionam. Uma versão geral deste ceticismo afirmaria que inexiste "verdade objetiva" sobre qualquer coisa, enquanto uma versão seletiva sustentaria que só há verdade objetiva sobre afirmações descritivas, como no caso das afirmações matemáticas, mas não no caso de afirmações avaliativas (morais, éticas, interpretativas ou estéticas) (DWORKIN, 1996, p. 1). A segunda modalidade de ceticismo analisada por Dworkin é o ceticismo interno. Esta espécie de ceticismo pressupõe a verdade em algum tipo de julgamento moral positivo. Assim, a posição cética interna negaria alguns grupos familiares de afirmações morais com base em outra afirmação moral, muitas vezes mais geral ou teórica. Por exemplo, temos aqueles que negam que atos sexuais sejam inerentemente bons ou ruins, certos ou errados, porque acreditam que apenas condutas que causem sofrimento sejam inerentemente ruins - assim, não sendo certo que tanto atos heterossexuais quanto homossexuais, apenas em si, causem sofrimento, não seria correto sustentar sua moralidade ou imoralidade (DWORKIN, 1996, p. 2). Certamente, as posições céticas vão além das apresentadas e possuem inúmeras subdivisões. De qualquer sorte, Dworkin acredita que o ceticismo externo seletivo (geralmente denominado de "subjetivismo" ou "emotivismo"), em suas versões mais refinadas, seja o que tem sido por mais tempo considerado como plausível - e corresponderia, também, à modalidade mais perigosa de ceticismo (DWORKIN, 1996, p. 1). Tais posições seriam aquelas que, como as exemplificadas no corpo deste trabalho, acreditam na existência de dois "níveis de discurso": assim, considerando o discurso de primeira-ordem, seria possível ao filósofo posicionar-se em questões morais - ele poderia pensar que a escravidão é injusta. Entretanto, em questões de segunda-ordem não haveria como se sustentar a objetividade na moral - a escravidão não seria objetivamente injusta. 
admitir o sentido e a validade de argumentos cujo sentido e validade ele quer negar.

Inúmeras questões morais são capazes de exemplificar este ponto, demonstrando uma incoerência intrínseca no ceticismo externo. Assim, por exemplo, não faz sentido sustentar uma posição contrária ao aborto (inclusive apresentando argumentos) e, ao mesmo tempo, afirmar não ser possível dizer se o aborto é "certo" ou "errado".

Certamente, os argumentos acerca da objetividade na moral vão muito além dos aqui apresentados, mas dentro dos meus objetivos acredito que esta seja a síntese essencial do que é trabalhado com maior profundidade por Dworkin ${ }^{78}$. Mas sendo um dos meus objetivos principais defender que minha concepção de casamento é melhor que a concepção apresentada por Finnis, resta analisar o que corresponderia à melhor interpretação dentro deste contexto.

Como mencionado, para Dworkin as práticas sociais atinentes a conceitos de natureza interpretativa buscam a melhor forma de se alcançar e concretizar os valores que conferem sentido a estes mesmos conceitos - de forma análoga, quando trata da interpretação de textos literários, a hipótese estética dworkiniana sugere que o intérprete deve buscar o melhor sentido que um texto pode ter. Logo, é possível sustentar que uma determinada concepção de um conceito interpretativo poderá ser melhor que outra. Mas como é possível auferir qual concepção é a melhor?

Certamente, a resposta para esta questão não está na visão da maioria. É incorreto atribuir à Dworkin o caráter de convencionalista, como se a melhor resposta para problemas morais ou a melhor concepção de um dado conceito pudesse ser encontrada na opinião da maioria das pessoas. Isso ocorre porque, dentre outros fatores, Dworkin estabelece uma distinção fundamental entre consenso por convenção e consenso por convicção.

Muitas coisas podem ser consideradas verdadeiras por convenção. Não seria impossível imaginar que muitas normas jurídicas são aceitas por alguns juízes e advogados apenas porque todas as demais pessoas as aceitam. Entretanto, nem todo acordo será oriundo de uma convenção (DWORKIN, 1986, p. 136). Na realidade, se analisarmos a prática jurídica, veremos que seus atores muitas vezes apresentarão visões contrárias à mera convenção, demonstrando argumentativamente as razões que justificam suas

\footnotetext{
${ }^{78}$ Para os leitores que desejarem se aprofundar sobre o tema, inclusive sobre as críticas dworkinianas às demais formas de ceticismo, recomendo o estudo da primeira parte do livro Justice for Hedgehogs (DWORKIN, 2011).
} 
diferentes posições. Em outras palavras, o que move a prática judicial é o fato de que o consenso, na realidade, refere-se a uma questão de convicção (DWORKIN, 1986, p. 136/137). Assim, como sustenta Stephen Guest (2010, p. 136/137), ao interpretar a posição dworkiniana:

\begin{abstract}
Para ele, a moralidade não é constituída por convenções públicas que digam: uma conduta é moralmente exigida ou permitida pelo teste daquilo que pensa a maior parte das pessoas (...) Um consenso, ao invés, significa uma coincidência das mesmas convicções. Em nossa comunidade, há uma coincidência de convicções, sustentadas de forma independente, de que o estupro é moralmente errado. Mas o fato do consenso não é a razão para achar o estupro errado, uma vez que pensamos que ele é errado por razões independentes disso (violência; dominação; danos; dor; sofrimento) ${ }^{79}$.
\end{abstract}

Deve-se ressaltar, ainda, que a espécie de consenso contemplada na ideia de conceitos interpretativos diz respeito a um mínimo de concordância, refletida nos paradigmas que compartilhamos e que conformam os usos que damos aos nossos $\operatorname{conceitos}^{80}$. Mas como observado, disso não se segue que a melhor interpretação ou concepção de um conceito são oriundas de uma convenção ou vontade da maioria.

A ideia de paradigmas e de práticas compartilhadas sugere a maneira com que Dworkin responde à questão de como identificar uma melhor interpretação dentre várias que podem ser formuladas sobre valores ou conceitos. E na medida em que não tratamos os valores e conceitos que compartilhamos de forma isolada, as ideias de ajuste ("fit") e de coerência são fundamentais para compreender de que maneira uma interpretação será melhor que outra.

Dworkin sustenta que os valores que compartilhamos estão diretamente interligados e se sustentam mutuamente (DWORKIN, 2011, p. 10). Dessa maneira, a forma de se descobrir se dada concepção de um valor é melhor, certa ou verdadeira depende da análise deste valor em conjunto com os demais valores compartilhados, e não em razão de elementos externos à moralidade. Da mesma maneira que a interpretação é, desde o início, "interpretativa", a moralidade também é "moral" desde o princípio ( "morality is moral, all

\footnotetext{
${ }^{79}$ Em sentido análogo, temos a posição de Ronaldo Porto Macedo Jr. (2010, p. 8-9): “o critério para a melhor concepção não é convencional por si mesmo, mas antes argumentativo, muito embora se apoie em regras sociais em algum momento. Uma interpretação é melhor não porque é aceita pela maioria ou se ancora na convenção dominante, mas porque em seu apoio existe uma melhor justificação ou argumentação racional".

${ }^{80} \mathrm{O}$ "grau" de concordância, certamente, não é determinado à priori. Nas palavras de Dworkin (2011, p. 131/132): "How much agreement is necessary at each stage to sustain the practice is not fixed a priori. We discover how much and what kind of disagreement can be tolerated only ex post: only by judging whether some particular practice of agreement and disagreement remains fruitful or runs into argumentative sand".
} 
the way down") (DWORKIN, 2011, p. 131) Neste sentido, afirma Dworkin (2011, p. 11, tradução livre):

\begin{abstract}
Julgamentos de valor são verdadeiros, quando verdadeiros, não em virtude de qualquer correspondência, mas em vista do caso substantivo que pode ser feito para eles. O campo moral é o campo do argumento, não do fato bruto. Então não é implausível - ao contrário - supor que não há conflitos mas apenas assistência mútua neste campo. Ou, o que dá no mesmo, quaisquer conflitos que acreditamos serem intratáveis demonstram não desunião, mas uma unidade de valor mais fundamental que produz tais conflitos como resultados substantivos.
\end{abstract}

Pode-se afirmar, portanto, que uma concepção será melhor que outra quando melhor se ajustar a esta rede de valores e paradigmas que compartilhamos. A determinação deste "ajuste" (fit) ocorre de maneira argumentativa, e não através de fatores externos ao raciocínio interpretativo. Também se deve atentar para a questão da coerência, como na hipótese já mencionada do intérprete de obras literárias - da mesma maneira que o intérprete literário está limitado por questões de integridade da arte (o gênero do texto, por exemplo, se é um romance ou uma ficção-científica), o intérprete moral deve ser sensível aos valores que fundamentam a prática social que está analisando. Ronaldo Porto Macedo Jr. (2010, p. 7/8) resume bem este importante ponto da teoria dworkiniana:

Para Dworkin uma concepção é melhor que outra, e não apenas diferente, quando mais se ajusta adequadamente ("Fit") aos paradigmas socialmente compartilhados desse mesmo conceito e é capaz de descrever as práticas paradigmáticas de maneira mais coerente. Coerência e ajuste adequado são, assim, critérios também socialmente compartilhados, que nos permitem avaliar e julgar a superioridade de concepções rivais sobre um mesmo conceito.

Dessa forma, se retomarmos o exemplo da interpretação de um romance da Agatha Christie como um "tratado filosófico sobre a morte", resta claro que esta é uma interpretação ruim. Uma boa interpretação, que busque analisar tal romance sob sua melhor luz, deverá se ajustar adequadamente aos padrões compartilhados sobre o que é um "romance", mantendo coerência aos demais elementos que permitam sua identificação como tal. De forma análoga, a interpretação de um conceito interpretativo não se ajustará adequadamente e nem será coerente caso os valores que entendemos relevantes em sua configuração sejam ignorados - a interpretação, no caso, não será capaz de apreender o point valorativo da prática social a que se refere o conceito interpretativo. Neste sentido, somos capazes de identificar uma boa e uma má interpretação, e consequentemente, uma melhor e uma pior interpretação. 


\title{
2.3. O CASAMENTO ENQUANTO CONCEITO INTERPRETATIVO
}

Creio que com estas observações gerais sobre elementos da teoria dworkiniana fique mais fácil perceber uma das teses centrais deste trabalho: uma resposta satisfatória à questão “o que é casamento?” deve atentar para o contexto prático em que este conceito está inserido, e a melhor concepção de matrimônio será aquela que se ajusta da forma mais adequada e coerente às demais práticas e conceitos que compartilhamos socialmente. Em outras palavras, para entender o que é a prática social do casamento devemos analisá-lo interpretativamente.

Isso significa, como observado, que o sentido do casamento não é definido de forma criterial, ou tratando-o como se fosse um conceito de tipo natural. Na medida em que o casamento corresponde a uma prática social com um point moral, a melhor concepção deste conceito tomará por base uma interpretação adequada e coerente dos valores que lhe dizem respeito.

Dworkin não realiza um estudo amplo sobre quais seriam os valores que constituem o casamento e de que maneira eles se relacionam. Entretanto, é inegável que o casamento deve ser tratado enquanto um conceito interpretativo. Se já não bastassem suas críticas às tentativas de se buscar a "essência" do matrimônio através de critérios ou mediante seu tratamento como tipo natural, Dworkin faz as seguintes observações, no final do terceiro capítulo de seu livro Is Democracy Possible Here? (DWORKIN, 2006a, p 86, tradução livre):

\begin{abstract}
A instituição do casamento é única; ela é um modo distinto de associação e comprometimento que carrega séculos e volumes de significado social e pessoal. Nós não podemos mais criar um modo alternativo de comprometimento carregando uma intensidade paralela de significado da mesma forma que não podemos criar um substituto para a poesia ou para o amor. O status do casamento é, portanto, uma fonte social de valor insubstituível para aqueles aos quais é oferecido; ele permite que duas pessoas, juntas, criem valor em suas vidas de uma forma que elas não poderiam criar se esta instituição nunca tivesse existido.
\end{abstract}

Consequentemente, para Dworkin, o valor criado pelo casamento corresponde a um point de natureza moral que deve ser levado em consideração quando buscamos explicar este conceito. Para tanto, é necessário verificar com quais valores o casamento se relacionaria, bem como a forma com que tais valores se relacionam entre si - é preciso, 
portanto, analisar o matrimônio como um conceito correspondente a uma prática social compartilhada.

Ao se perceber que o casamento é uma instituição única, enquanto forma distinta de comprometimento e com um significado moral especial, tem-se que a luta de lésbicas e gays pelo matrimônio não se resolveria com a criação de uma espécie distinta de "união civil”, ainda que garantisse os mesmos direitos e deveres atinentes ao matrimônio. Pois o casamento não se resume às perspectivas de natureza material da união (questões sucessórias e de natureza previdenciária, por exemplo), mas possui também esta natureza imaterial, moral, que aqui se destaca.

Dworkin sustenta que esta justificativa corriqueira, de que não se estaria discriminando homossexuais caso fosse criada uma união civil entre pessoas do mesmo sexo com as mesmas vantagens materiais do casamento, refuta a si mesma. Em suas palavras,

\begin{abstract}
Existe mesmo uma justificativa mais popular: de que a sociedade não discrimina homossexuais se proíbe o casamento entre pessoas do mesmo sexo, mas cria uma união civil para tais pessoas que provê muitas ou todas as vantagens materiais do casamento. Este argumento refuta a si mesmo. Se não houvesse diferença entre as consequências materiais e legais do casamento ou uma união civil planejada, então por que o casamento deveria ser reservado aos heterossexuais? Só poderia ser porque o casamento tem uma dimensão espiritual, que alguns casais do mesmo sexo desejam tanto quanto os heterossexuais. Ou pode ser a ressonância da história e cultura que descrevi e que ambos os tipos de casais almejam. Mas, sejam quais elas forem, se existem razões para renegar o status a casais gays então estas também seriam razões porque a união civil não é uma oportunidade equivalente (DWORKIN, 2006a, p. 87, tradução livre).
\end{abstract}

Logo, a manutenção de dois institutos materialmente e juridicamente iguais, mas com "nomes" distintos (o que implicaria dizer que a questão é meramente taxonômica), só se sustentaria na hipótese de ambos serem, em algum outro sentido de natureza imaterial ou moral, diferentes. Esta visão não se sustenta na medida em que não são apresentadas razões pelas quais casais de lésbicas ou gays não possam compartilhar, assim como heterossexuais, desta "dimensão axiológica" do matrimônio - ela permanece sendo injustificadamente discriminatória. E caso estas razões existissem, não faria sentido a equivalência material entre o casamento e uma pretensa "união civil homossexual".

O casamento possui particular relevância na moralidade social. Ser casado ou não, por exemplo, pode implicar em uma ascensão mais ou menos fácil no ambiente de trabalho. Ao menos no Brasil, as pessoas veem o casamento e outras formas de união civil (a união estável) sob perspectivas diferentes, e atribuem maior importância e legitimidade 
ao primeiro, pouco importando se a lei considera ambas as modalidades como uma entidade familiar (e ainda que garantisse, efetivamente, os mesmos direitos e deveres daí decorrentes). A questão, portanto, transcende a perspectiva linguística e assume contornos nitidamente políticos e morais.

Não é por outra razão que, mesmo aqui no Brasil, homossexuais buscaram seu reconhecimento como entidade familiar, obtendo êxito no Supremo Tribunal Federal através da demanda pelo reconhecimento da chamada união homoafetiva ${ }^{81}$. Lésbicas e gays não se contentaram apenas com questões de ordem material, que em certa medida já vinham sendo atendidas através da interpretação analógica, pelos tribunais, de que casais homossexuais constituiriam uma "sociedade de fato". A questão é que homossexuais não se unem como se estivessem "montando uma barraca na feira", como afirmou Luis Roberto Barroso em sua sustentação oral no citado julgamento da união homoafetiva ${ }^{82}$. Ao contrário, homossexuais se unem porque, assim como heterossexuais, possuem a capacidade e a vontade de constituir um núcleo família - são mulheres e homens dotados de plena autonomia na forma com que conduzem suas vidas e desejos. Todo e qualquer indivíduo tem um direito moral à procura da felicidade, de realizar-se através da externalização de seus sentimentos de carinho, apreço e afeto, por quem quer que seja independentemente de sua orientação sexual. A luta pelo casamento, neste sentido, representa a luta pelo reconhecimento de um direito moral.

Estas questões envolvem pontos que fogem do objetivo central deste trabalho, que é de natureza conceitual. De qualquer forma, serão tratadas com maior atenção, ainda que de forma relativamente breve, no último capítulo deste trabalho. Por enquanto, fica claro que o casamento homossexual não se limita a uma questão meramente taxonômica, justamente porque se pretendemos explicar o matrimônio enquanto uma prática social, devemos fazêlo de forma interpretativa ${ }^{83}$.

\subsection{O QUE É VALIOSO? AS CONCEPÇÕES DE FINNIS E DWORKIN}

\footnotetext{
${ }^{81}$ Trata-se da já citada Arguição de Descumprimento de Preceito Fundamental (ADPF) no . 132, julgada em maio de 2011.

82 A sustentação oral de Luis Roberto Barroso na ADPF nº 132 pode ser vista no site do YouTube, no seguinte link: <http://www.youtube.com/watch?v=ECIWP1c9-Vg> Acesso em: 21 jun. 2012.

${ }^{83}$ É curioso notar que nada impede a existência de uma concepção criterial de casamento que possa abranger casais de indivíduos homossexuais. Ainda assim, tal concepção não seria satisfatória para explicar o sentido do casamento enquanto uma prática social compartilhada que tem em vista valores e paradigmas, e que está inserida em um dado contexto histórico.
} 
Dworkin é claro ao sustentar que seria um erro afirmar que, em sua "essência", o casamento corresponde apenas à união entre homem e mulher, pois isso seria tratá-lo como um conceito criterial ${ }^{84}$ (DWORKIN, 2006b, p. 9/10). Finnis, entretanto, sustenta que o casamento corresponde à prática de atos de tipo reprodutivo em um ambiente de amizade conjugal - logo, resta claro que o casamento finnisiano resume-se à união entre homem e mulher. Mas será que é apenas por isso que se poderia afirmar que Finnis trata o casamento enquanto um conceito criterial?

Creio que Finnis discordaria desta crítica. Em sua defesa, podemos recorrer à ideia de bens humanos básicos. Sendo o casamento também um bem humano básico, ele corresponderia a um fim racional da ação humana. A participação no bem do casamento, consubstanciado em seu point duplo e à luz das exigências da razoabilidade prática, é que o dotaria de sentido moral.

Desse modo, a procriação (ou prática de atos de tipo reprodutivo) e a amizade entre os cônjuges não são, propriamente, elementos morais. Correspondem a razões para a ação (e é esta que poderá ser apreciada moralmente). Juntos representam o "fim" do bem do casamento, de forma que são igualmente inderivados, indemonstrados, indemonstráveis, autoevidentes e incomensuráveis. Atos de tipo reprodutivo e amizade conjugal devem ser compreendidos de forma interligada - atos de tipo reprodutivo fora da relação de fides entre os cônjuges são uma afronta ao bem do casamento (pois corresponderiam à simples busca hedonista pelo prazer), e uma relação entre homem e mulher que não envolva sua prática equivaleria, na melhor das hipóteses, ao bem da amizade.

É neste momento que a ideia finnisiana de bens humanos básicos, apresentada no primeiro capítulo, se faz particularmente relevante. Enquanto bem humano básico, o casamento é apreendido como tal por qualquer pessoa com um mínimo de experiência e conhecimento dos termos. Em outras palavras, parece-me que o que Finnis quer dizer é que pouco importa se o bem humano do casamento é ou não universalmente reconhecido ou disputado. O relevante é que ele é inderivado e indemonstrável por ser autoevidente. Ele independe de qualquer prova de argumentação, assim como o conhecimento, a vida e a amizade. Dessa forma, nas palavras de Finnis (2011b, p. 70, tradução livre):

\footnotetext{
84 "Developing a theory of this kind [criterial] of concept means proposing a more precise definition for some particular purpose. But it would be a mistake to claim that any one more precise definition better captures the essence of the concept than others. It is a mistake to say, for example, as many now do, that the essence of marriage is a union between a man and a woman so that 'gay marriage' is an oxymoron" (DWORKIN, 2006b, p. 9/10).
} 
A não-derivabilidade, em alguns casos, diz respeito à falta de justificação e de objetividade. Mas em outros casos ela prenuncia a autoevidência; e estes casos podem ser encontrados em todo campo de pesquisa. Pois em cada campo existe e deve existir, em algum ponto ou pontos, um fim da derivação e inferência. Neste ponto ou pontos, nos encontramos diante da autoevidência, que torna possível todas as inferências subsequentes neste campo.

Desse modo, aquelas pessoas que se puseram a refletir sobre o casamento e seu point, analisando a própria complexidade da vida humana e suas contingências, concluiriam que o casamento é, evidentemente, um bem humano básico - de forma semelhante à consideração óbvia de que uma pessoa bem informada está em uma situação melhor do que uma pessoa ignorante (FINNIS, 2011b, p. 72). Não é à toa que Finnis, ao formar sua lista de bens humanos básicos, não busca “explicá-los” através de qualquer tipo de provas ou inferência; ao contrário, o leitor do quarto capítulo de Natural Law and Natural Rights é instado a se questionar: “...é um bem em si mesmo, você não acha?” (FINNIS, 2011b, p. 85-86, tradução livre).

Os bens humanos básicos para Finnis são incomensuráveis, autoevidentes e indemonstráveis. Vida, conhecimento, amizade, dentre outros, são valores que não dependem um do outro para existir - eles são independentes e, ao menos neste sentido, podemos afirmar que são autônomos. Por tal razão, conjuntamente com os demais "princípios de Direito Natural” (notadamente os requisitos da razoabilidade prática), acredito que Finnis constrói uma estrutura "escalonada" da ação humana e do fenômeno moral. Ele é analítico nos moldes hartianos: enquanto para Hart o Direito tem em seu ápice uma regra de reconhecimento, de onde derivariam as demais regras do sistema jurídico, para Finnis o Direito integraria uma "pirâmide" ainda maior, que envolveria também a moral e em cujo ápice encontraríamos tais valores (os bens humanos básicos e demais princípios de Direito Natural), apreensíveis através da experimentação e traduzidos como fins de toda e qualquer ação humana que se pretenda racional.

Fica claro, portanto, que a própria estruturação da teoria de Finnis evita que ela seja "circular" como é a teoria dworkiniana - na qual os valores são vistos de maneira integrada, como se formassem uma grande rede ou "cúpula geodésica" (DWORKIN, 2006b, p. 160). Como mencionei anteriormente, para Dworkin a melhor concepção de um conceito interpretativo (onde se inserem valores morais e o próprio casamento) é alcançada através de um ajuste adequado e coerente com relação aos demais paradigmas e valores que compartilhamos. Neste sentindo, tratando do conceito de justiça, Dworkin (2011, p. 162/163, tradução livre) afirma: 


\begin{abstract}
Nós defendemos uma concepção de justiça ao colocarmos as práticas e paradigmas deste conceito em uma rede maior de outros valores que sustentam nossa concepção. Nós podemos, a princípio, continuar a expandir nosso argumento, explorando outros valores até que, como eu disse, o argumento encontra a si mesmo. A circularidade, se existe, é global através de todo o domínio do valor.
\end{abstract}

Particularmente, acredito que a significativa pluralidade de valores e paradigmas que compartilhamos socialmente evita que a "circularidade moral" no pensamento de Dworkin se transforme em uma mera tautologia. A riqueza de valores existentes faz com que, na prática, seja muito difícil imaginar alguma situação na qual o argumento "encontra a si mesmo".

Estas observações evidenciam uma diferença substancial entre as maneiras pelas quais Finnis e Dworkin concebem o valor. Um dos pontos que entendo ser relacionado a esta questão diz respeito à mencionada autonomia dos bens humanos básicos na teoria de Finnis, e à integração dos valores na teoria de Dworkin. Esta distinção é notada pelo próprio Dworkin, ainda que ele não atribua a ideia de autonomia dos valores diretamente à Finnis.

Dworkin afirma ser possível analisar os valores de duas formas diferentes: de maneira autônoma ou integrada. Nós trataríamos os valores de forma autônoma quando acreditássemos que eles são separados e fixados de maneira independente das nossas preocupações com uma boa vida (nós respeitaríamos os valores porque eles seriam apenas valiosos em si mesmos, de modo que estaríamos simplesmente errados se não os reconhecêssemos). Por outro lado, tratar os valores de maneira integrada significa considerá-los à luz de nossos interesses em uma boa vida - porque aceitar os valores, de uma forma ou de outra, melhora nossa vida de alguma maneira (DWORKIN, 2006b, p. 156). Tratando especificamente da amizade, Dworkin (2006b, p. 157-158, tradução livre) afirma:

Muitas pessoas estimam a amizade: elas pensam que uma vida sem conexões próximas com os outros é empobrecida. Mas nós não pensamos que a amizade é o que é, como um planeta, e que sua única conexão com uma vida desejável é que uma vida desejável é aquela que a reconhece, seja qual ela for. Eu não quero dizer, certamente, que relacionamentos como a amizade são valiosos apenas pelos estritos benefícios que eles trazem aos amigos, como cooperação para se alcançar objetivos. Mas seu valor não é independente da forma com que eles melhoram a vida de outras maneiras; nós podemos discordar sobre exatamente quais são estas maneiras - amizade é um conceito interpretativo - mas ninguém pensa que a amizade permaneceria algo de importante se não fosse nada para a vida de amigos, exceto fazer amigos. 
A amizade é um exemplo interessante porque Finnis sustenta que ela, assim como o conhecimento, a vida e o próprio casamento, corresponde a um bem humano básico. Mas é importante perceber que o sentido em que a amizade corresponde a um bem "autônomo", para Finnis, decorre justamente da sua inderivabilidade, autoevidência, incomensurabilidade e indemonstrabilidade. Tal fato parece sugerir uma incompatibilidade entre as teorias de Finnis e Dworkin, pois os pressupostos que utilizam para analisar os valores são distintos.

Não é por outra razão que, em meu entender, muitas das críticas dirigidas à concepção de casamento de Finnis são inócuas. Elas não conseguem lidar com o fato de que o casamento corresponderia, na perspectiva finnisiana, a um bem humano básico. Assim, por exemplo, os debates entre alguns teóricos de alinhamento liberal e os jusnaturalistas acerca do casamento de casais estéreis, com base na ideia de união biológica, parece não chegar a lugar algum - ponto que será tratado com maior clareza adiante.

Diante destas considerações, se retomarmos a pergunta inicialmente formulada ("Finnis trata o casamento enquanto um conceito criterial?") acredito que a resposta deva ser negativa. Isso porque, se o casamento é um bem humano básico, não há que se falar em critérios "escolhidos" por Finnis tendo em vista um determinado propósito, muito menos no fato de que tais critérios seriam "compartilhados" tal qual o compartilhamento do conceito de triângulo equilátero. Pouco importaria, portanto, se hoje a maior parte das pessoas acredita que o casamento não constitua uma união entre homem e mulher. Tais indivíduos estariam simplesmente equivocados por não conseguirem perceber que a união biológica e a amizade conjugal são, de forma evidente e indemonstrável, elementos constitutivos do bem básico do matrimônio. Logo, o casamento é o que é porque esta seria a única maneira de concebê-lo racionalmente - algo revelado pela própria "experiência".

É curioso notar, ainda, que a pretensão de objetividade da concepção finnisiana de casamento se dá de forma completamente distinta da proposta teórica sugerida por Dworkin. Esta objetividade não se daria dentro de um empreendimento interpretativo, através de uma concepção que esteja preocupada com o ajuste e coerência ao contexto e demais paradigmas que compartilhamos. A “objetividade" do casamento, para Finnis, reside no fato de que é um valor em si evidente e autônomo. Se do lado finnisiano a objetividade (i.e., a concepção "correta" de casamento) decorre da inderivabilidade e indemonstrabilidade constatadas pela autoevidência, do lado dworkiniano esta objetividade 
(i.e., a "melhor" concepção de casamento) está atrelada à coerência dos argumentos e justificações em favor de uma concepção ${ }^{85}$.

De qualquer modo, o que não se deve esquecer é que tanto a teoria de Finnis quanto a de Dworkin não se pretendem meras “descrições” do fenômeno moral, jurídico ou político. Suas teorias são normativas e versam sobre questões de razão prática, entendidas aqui como questões fundamentais sobre como devemos agir (“o que deve ser feito?"), seja no campo ético, moral, político ou jurídico. Não é por outra razão que ambos elaboraram inúmeros artigos sobre questões controversas como aborto, eutanásia e pornografia, relacionando-os diretamente com suas perspectivas teóricas. Logo, mesmo quando Finnis sustenta a "autoevidência" do casamento como um bem humano básico, esta autoevidência tem em vista um contexto prático - o casamento não seria um bem autoevidente fora de um mundo onde as pessoas efetivamente se casassem e pudessem experienciá-lo enquanto um bem.

\subsubsection{Finnis versus Dworkin: qual teoria é metodologicamente mais adequada?}

Mas uma vez apresentadas as diferenças e semelhanças entre os modelos teóricos de Finnis e Dworkin, resta responder as seguintes questões: qual é a melhor teoria para se explicar o casamento e por quê?

É possível criticar a concepção finnisiana de dois modos distintos. De um lado, podemos contestar a autoevidência e inderivabilidade do casamento com base em bens muito mais "evidentes" que o casamento, o que implica em uma crítica interna ao pensamento de Finnis (i.e., criticar finnisianamente o próprio John Finnis). Por outro lado, podemos ter em mente as consequências teóricas resultantes desta maneira de concebê-lo

${ }^{85}$ Creio que esta divergência fica clara quando um jusnaturalista como Robert George não consegue compreender o papel exercido pela ideia de igualdade na teoria de Dworkin: "I simply wish to observe that the abstract right to equality appears to be foundational in Dworkin's theory of political morality - he makes no effort to derive it from more fundamental principles. But this lack of a derivation is problematic in that the proposition it states appears to be neither a self-evident practical principle nor a necessary truth of any kind. Tracing back a chain of practical reasoning from the moral decision to recognize a specific political right, one dos not ultimately arrive at a grasp of the self-evident intelligibility of an abstract right to equality which terminates the chain by leaving no relevant questions unanswered - nor does one contradict oneself in denying the abstract right" (GEORGE, 1993, p. 86). O que fica evidente nesta crítica formulada por George é o fato de que, para ele, o "ponto de partida" da moralidade política deve corresponder a princípios práticos inderivados, que assim o são em razão da sua autoevidência e da impossibilidade de negá-los sem entrar em contradição. Somente em um contexto como este, para George, seria possível afirmar que a concepção dworkiniana de igualdade é objetivamente correta e, neste sentido, "fundacional" em sua teoria de moralidade política. Mas como visto, se a igualdade corresponde a um valor na teoria dworkiniana, seu sentido só pode ser apreendido de maneira interpretativa e integrada aos demais valores que compartilhamos. Sobre a maneira pela qual Dworkin concebe o valor da igualdade dentro de sua teoria política, recomendo a obra Sovereign Virtue: the theory and practice of equality (DWORKIN, 2000). 
(i.e., apresentar as insuficiências da concepção finnisiana considerando o contexto prático em que estamos inseridos). No próximo capítulo, argumentarei em prol de ambas as possibilidades.

Por hora, pretendo centrar-me em uma das consequências teóricas da concepção finnisiana que demonstra a superioridade da posição de Dworkin: a teoria dworkiniana é uma forma mais adequada de se conceber o casamento porque é capaz de explicar satisfatoriamente o desacordo sobre algo que, para Finnis, seria autoevidente. Em outras palavras, Finnis não tem escapatória quando contestado, por exemplo, sobre as razões que tornam a união biológica um elemento intrínseco conceitual do casamento. Quando instado a responder as críticas que lhe são formuladas, o máximo que pode fazer é reiterar o caráter autoevidente do matrimônio, como se a discordância sobre sua concepção de casamento fosse análoga à negação de que o conhecimento corresponde a um fim da ação humana.

Mas muitas pessoas discordam que o sexo "correto" está limitado à ideia de união biológica, como se a única "função" a ser observada pelos órgãos genitais fosse a reprodução - e que qualquer ato sexual além da união biológica corresponderia à "instrumentalização" do corpo humano. Dentre estas pessoas se encontram autores como Stephen Macedo e Andrew Koppelman, cujas críticas serão analisadas no próximo capítulo. Meu interesse, neste momento, é ressaltar o fracasso da teorização finnisiana sobre o casamento quando apresentadas estas visões divergentes. O que Finnis (e outros autores já citados neste trabalho, como Robert George) faz, em última análise, é sustentar a incapacidade de seus críticos de "perceberem" a autoevidência do bem do casamento. É como se ele fosse dotado de uma inteligência superior ou clarividência que lhe permitissem constatar evidências em uma realidade marcadamente contraditória, como se denota através dos inúmeros debates sobre o significado e sentido do casamento.

Dworkin denomina esta ideia, de que determinadas discordâncias podem ter por objeto a incapacidade cognitiva de alguém, de tese da incapacidade. Ele a atribui a Crispin Wright, enfrentando a questão nos seguintes termos:

É plausível interpretar a afirmação de que o aborto é objetivamente imoral, ou que o genocídio é realmente errado, ou que a perversidade do terrorismo é um fato moral, como se incluísse o que poderíamos chamar de alegação geral de incapacidade: que qualquer um que não concorde com nossa opinião sofre de algum impedimento cognitivo que explique seu engano? (...) As pessoas não têm nenhuma razão para afirmar que aqueles que discordam delas carecem de alguma informação que elas têm, ou sofrem de alguma incapacidade intelectual ou falha de caráter, quando elas não possuem evidência de tal ignorância, incapacidade ou falha. Esta afirmação, nestas circunstâncias, será retórica vazia, não adicionando 
nada à alegação substantiva original. Ninguém pode pensar que seu argumento ou posição foi aprimorado por isso (DWORKIN, 1996, p. 10, tradução livre).

Quando questionamos se o casamento é, de fato, um bem humano básico, Finnis nada pode fazer a não ser reafirmá-lo como tal. Este ponto ficará mais claro quando analisarmos as críticas que já foram dirigidas contra a concepção finnisiana, notadamente as que versam sobre a ideia de união biológica, e as respostas apresentadas por Finnis onde, claramente, sustenta o "erro" de seus críticos por não notarem o caráter autoevidente de sua concepção de matrimônio. O ponto que pretendo ressaltar por hora é que, metodologicamente, a posição de Finnis é incapaz de compor um debate, apresentando argumentos que sejam capazes de desconstruir e demonstrar os equívocos dos seus críticos Sua posição, em última análise, nada pode fazer diante da ocorrência de divergências - o que demonstra que a metodologia por ele adotada é claramente insatisfatória em um contexto marcado por diferentes ideias e concepções.

Dworkin, entretanto, adota uma postura metodológica que tem por alvo a possibilidade de concepções controvertidas. Este é um ponto marcante em sua teoria, presente desde artigo Modelo de Regras I, constante na obra Levando os Direitos à Sério (DWORKIN, 2010). A partir deste artigo, Dworkin buscou demonstrar em inúmeros outros textos que as divergências entre juristas sobre o conceito de Direito são muito mais fundamentais do que alegavam positivistas como Hart, que se sustentavam na ideia de regra de reconhecimento, dentre outros. Não pretendo analisar este debate em específico, mas sim ressaltar que muitas de suas observações sobre as controvérsias conceituais se aplicam ao caso do casamento.

Acredito que este ponto já tenha sido tratado ao longo do presente capítulo, particularmente quando ressaltei as diferenças entre conceito e concepção, e a ideia de casamento enquanto um conceito que, relacionado às práticas sociais compartilhadas, deve ser apreendido de modo interpretativo. Um breve resumo, entretanto, se mostra interessante - a retomada de alguns pontos centrais deixará mais claras as razões que me levam a preferir a metodologia adotada por Dworkin.

Como sustentei, para Dworkin conceitos de natureza moral admitem inúmeras concepções que, muitas vezes, serão divergentes. A forma com que devemos analisá-las decorre da ideia de integração valorativa, até porque a forma com que argumentamos em favor de uma concepção importa em ressaltar paradigmas compartilhados socialmente. Para defender determinada concepção de um dado conceito moral, devemos estar atentos aos usos e finalidades que são atribuídos ao conceito - e daí decorre a ideia de um point ou 
finalidade moral, como no caso do debate hipotético sobre a cortesia. Quando assim o fazemos, buscamos justificar nossa concepção e demonstrar sua superioridade de modo argumentativo, asseverando sua adequação e coerência com os demais valores que também são compartilhados pelo nosso interlocutor. Trata-se de procurar uma base que possibilite a inteligibilidade da própria discussão e que gere a capacidade de avaliar a correção ou não de uma concepção, contrastando-a com a prática em que está inserida. Como visto, não se trata de recorrer a uma ideia "convencionalista" ou à visão da maioria, mas sim de defendermos argumentativamente nossas próprias convicções. O interessante é que na medida em que somos instados com "porquês" e pedidos para novas e cada vez mais profundas justificações, apelamos para graus cada vez maiores e mais abstratos do raciocínio moral - até um momento em que, de fato, a mera discordância transforme o debate em um nonsense.

Neste sentido, uma crítica de matriz dworkiniana à posição metodológica de John Finnis é possível. Dworkin é capaz de ver a posição de Finnis como uma posição moral substantiva, inserida dentro de um contexto controvertido - e este contexto, quando levadas em consideração a adequação e coerência da concepção finnisiana, nos permite concluir que esta é uma concepção ruim: ela é incapaz de fornecer argumentos e razões substantivas no calor do debate - quando, por exemplo, é contestada a ideia de união biológica. Se for possível notar paradigmas muito mais fundamentais do que a união biológica, quando se trata do casamento, não faz sentido que Finnis desconsidere o debate alegando sua autoevidência enquanto bem humano básico. É possível discordar de sua concepção casamento, sem que esta discordância seja análoga àquela do indivíduo que discorde sobre o bem do conhecimento.

No próximo capítulo desenvolverei com mais clareza tais ideias, demonstrando argumentativamente os efetivos que a incongruência metodológica de Finnis é capaz de acarretar. Por enquanto, resta justificada a minha preferência pela posição de Ronald Dworkin, considerando a relevância conferida às convicções justificadas dentro do debate de natureza conceitual e moral, bem como a sua aptidão para lidar com divergências de cunho teórico.

\subsubsection{A ideia de valor intrínseco}

A teoria dworkiniana acaba sendo relevante também quando percebemos que, não sendo o casamento um bem humano básico, uma concepção deste conceito deve ser 
adequada e coerente em sua relação com os demais valores que o conformam. Em síntese, o casamento deve ser visto enquanto um conceito interpretativo, que se encontra dentro de um contexto histórico determinado - não sendo adequado falar em sua autoevidência ou indemonstrabilidade. O casamento não tem valor "por si mesmo", de forma autônoma, mas deve ser visto de forma integrada com outros valores.

Mas e quanto a tais valores que dotariam o casamento de sentido? Talvez alguns independam de maiores demonstrações, sendo fins básicos da ação humana. Em certa medida, seriam eles os bens humanos básicos nos moldes finnisianos. No próximo capítulo, defenderei que a sexualidade e suas formas de manifestação se enquadram nesta perspectiva. Acredito que valores deste tipo correspondam àquilo que Dworkin denomina valores intrínsecos, ideia que, com as devidas cautelas, se aproxima da forma com que Finnis concebe os próprios bens humanos básicos.

Preliminarmente, é importante ressaltar que a ideia de bens humanos básicos, em si, não é de todo inadequada: o problema é quando eles não são suficientemente "básicos", como me parece ser no caso do casamento. Nestas hipóteses, cai-se no dogmatismo que ressaltei no ponto anterior, impossibilitando as divergências em um debate que, de outro modo, seria possível e enriquecedor.

Mas o que seriam valores intrínsecos para Dworkin? No capítulo O que é sagrado? do seu livro O domínio da vida (DWORKIN, 2009), Dworkin concebe a vida como um valor intrínseco, o que pode ser observado na forma com que se desenvolvem os debates sobre temas como o aborto e a eutanásia. O ponto levantado por Dworkin é de que alguns objetos e fatos da vida humana são considerados valiosos em si mesmos. Em suas palavras:

\footnotetext{
(...) grande parte de nossa vida tem por base a ideia de que os objetos ou os fatos podem ser valiosos em si mesmos. É verdade que, no viver cotidiano, as pessoas gastam a maior parte de seu tempo tentando conseguir ou fazer coisas que valorizam porque elas próprias, ou outra pessoa, delas necessitam ou desfrutam. É esta a razão pela qual tentam ganhar dinheiro e comprar roupas, comida ou remédios. Mas a ideia de que alguns fatos ou objetos são valiosos em si e por si próprios - que os reverenciamos não porque atendem aos nossos desejos ou interesses, mas pelo que são intrinsecamente - é também uma parte conhecida de nossa experiência. Muito do que pensamos sobre o conhecimento, a experiência, a arte e a natureza, por exemplo, pressupõe que, de diferentes maneiras, tais coisas sejam valiosas em si mesmas, e não apenas por sua utilidade ou pelo prazer ou satisfação que nos trazem. A ideia de valor intrínseco é um lugarcomum e ocupa posição central em nosso esquema comum de valores e opiniões (DWORKIN, 2009, p. 97).
}

A ideia de que alguns fatos e objetos tem valor intrínseco é apreendida pela própria forma com que as pessoas se comportam. É neste sentido que a ideia de valor 
intrínseco seria um "lugar-comum" nas muitas ocasiões em que expressamos nossos valores e opiniões. No caso específico da vida humana, por exemplo, Dworkin entende que ela corresponde a um valor intrínseco, vista como algo sagrado - seja em razão de uma força "criativa" de Deus ou do mundo gerador, como produto de uma criação natural (DWORKIN, 2009, p. 110), ou ainda em razão de uma força humana criadora e deliberativa, que reverenciamos de forma análoga ao reverenciarmos uma obra de arte (DWORKIN, 2009, p. 114). A vida humana seria valiosa por existir, não sendo importante em si que existam mais pessoas no mundo (o que implicaria em algo "incrementalmente" valioso). Ocorre que, uma vez que a vida tenha começado, entendemos que seja importante que ela floresça e não se perca (DWORKIN, 2009, p. 102).

Acredito que alguns dos valores que compõe a ideia de matrimônio são considerados, assim como a vida humana, como intrinsecamente valiosos. Deve-se evitar um sentimentalismo simplório, mas o fato é que amor, carinho e afeto são vistos como importantes em si mesmos, sendo difícil imaginar alguém que prescinda destes valores em sua vida. O mesmo com a sexualidade: suas diferentes formas de manifestação, seja heterossexual ou homossexual, também correspondem a algo intrinsecamente valioso. Este fato é particularmente relevante quando se observa o impacto causado, nas vidas individuais, quando a livre expressão da sexualidade é cerceada.

No próximo capítulo, apresento uma crítica direta à concepção finnisiana de casamento com base nestes pressupostos, bem como formulo uma concepção alternativa. Como se viu, há uma incompatibilidade entre as formas com que Finnis e Dworkin concebem o casamento. Se para Finnis o casamento corresponde a um bem humano básico, percebe-se que Dworkin não o vê como algo intrinsecamente valioso - e esta seria a categoria conceitual dworkiniana que mais se aproximaria da posição de John Finnis. É neste sentido que Dworkin se mostra relevante: ao nos alertar que o casamento deve ser apreendido de forma interpretativa, ainda que alguns dos valores que o compõe possam ser vistos como intrinsecamente valiosos. 


\section{POR QUE FINNIS ESTÁ ERRADO? UMA CONCEPÇÃO ALTERNATIVA DO CONCEITO DE CASAMENTO}

Os esforços de John Finnis em conceber o casamento como um bem humano básico estão completamente equivocados. Parece fazer sentido que a vida e o conhecimento constituam bens ou valores humanos básicos, que possam servir de razões autoevidentes, indemonstráveis e inderiváveis para nossa ação, mas não acredito que o matrimônio contemple as mesmas qualidades. Mas qual foi o erro cometido por Finnis?

Acredito que seu maior erro foi não ter percebido que, antes do casamento e da "união biológica", é a manifestação da sexualidade que deve ser vista como um dos fins básicos da ação humana. Heterossexuais, lésbicas, gays e outras minorias sexuais compartilham uma inclinação básica à busca de relações afetivas e sexuais. Defenderei neste capítulo que a maioria absoluta dos indivíduos possui tal inclinação, e que não faz sentido algum limitar a moralidade de sua expressão apenas à dita união biológica.

Tal fato evidencia que o casamento não pode corresponder a um bem humano básico, pois ele consiste na realidade em uma expressão institucionalizada dos valores que o constituem. Ele não é nem autoevidente, nem inderivável - antes, é uma instituição que tem por fim gerar e garantir direitos e deveres em um tipo muito específico e valioso de relação intersubjetivas. É com base nestas considerações que, ao final deste capítulo, defenderei uma concepção de casamento. Ao fazê-lo, pretendo me valer da teoria dworkiniana e analisar o matrimônio de forma interpretativa.

Antes, porém, acredito que seja interessante retomar algumas críticas que já foram elaboradas contra a posição de Finnis e outros jusnaturalistas. Alguns críticos acreditam que há uma incoerência interna na concepção de casamento de tais autores porque não haveria como defender o matrimônio entre indivíduos estéreis e, ao mesmo tempo, excluir conceitualmente a possibilidade de casamento entre homossexuais. $\mathrm{Ou}$, ainda, negar que o ato sexual possa ser intrinsecamente valioso em razão do prazer que ele é capaz de gerar assim como não mascamos chicletes pelo seu valor nutritivo, mas sim porque é uma atividade prazerosa e nem por isso se trata de algo imoral. Creio que tais críticas sejam externas ao pensamento finnisiano, e esbarram na ideia da união biológica enquanto algo 
que, para Finnis, é autoevidente. Assim, elas tornam claros os equívocos metodológicos da posição finnisiana, já ressaltados no capítulo anterior ${ }^{86}$.

\title{
3.1. CRÍTICAS EXTERNAS À CONCEPÇÃO FINNISIANA DE CASAMENTO
}

\subsubsection{Esterilidade e prazer no ato sexual}

Um dos autores que se empenharam em criticar a posição de Finnis e de outros jusnaturalistas foi Stephen Macedo. Em seu artigo Homosexuality and the Conservative Mind (MACEDO, 1995), Macedo entende que o foco de Grisez, Finnis e outros autores na ideia de união biológica e seu potencial procriativo é oportunista: sua única razão de ser seria garantir que heterossexuais estéreis possam se casar, excluindo homossexuais do matrimônio (MACEDO, 1995, p. 10).

Para Macedo, não faz sentido defender que heterossexuais estéreis, apesar da esterilidade, possam se conduzir de modo procriativo. Em outras palavras, não seria possível conceber a relevância da ideia de união biológica no conceito de casamento quando esta é incapaz de gerar novas vidas. Ela seria, em uma analogia atribuída a Andrew Koppelman, como apontar uma arma de fogo para alguém e puxar o gatilho. Enquanto conduta, é apropriada para matar - mas não quando a arma se encontra desmuniciada:

\begin{abstract}
O intercurso heterossexual estéril é, "como conduta", adequado para a geração? Como Koppelman sugere, apontar uma arma para alguém e puxar o gatilho é, em geral, a conduta adequada para matar, mas não quando a arma está descarregada. Nem quando a arma atira água ou é feita de alcaçuz. A Associação Nacional de Rifle poderia dizer, "armas não matam pessoas, balas matam pessoas". Da mesma forma, pênis e vaginas não se unem biologicamente, mas espermatozoides e óvulos sim (ao menos sob as condições adequadas). Para Finnis, entretanto, o crucial são pênis e vaginas, funcionais ou não (MACEDO, 1995, p. 10, tradução livre).
\end{abstract}

Andrew Koppelman apresenta uma crítica semelhante, nos seguintes termos:

Finnis reconhece que nem toda ejaculação de uma genitália masculina normal levará à concepção com sucesso, e talvez isso pretenda minimizar a diferença entre órgãos de homens normais e inférteis. (...) Mas ser esta conduta "adequada

\footnotetext{
${ }^{86}$ Acho curioso mencionar ainda que, quando tive oportunidade de ser monitor de Ética Profissional no segundo semestre de 2011, sob orientação de Ronaldo Porto Macedo Jr., os textos de John Finnis foram objeto de estudos por alunos de quarto ano. Foi muito difícil para os alunos compreenderem que o casamento corresponderia, na visão de John Finnis, a um bem humano básico. Assim, as críticas iniciais dos alunos invariavelmente caiam neste ponto: de que não fazia sentido que heterossexuais estéreis pudessem se casar, e que homossexuais não.
} 
para a geração" depende de se os órgãos são, de fato, adequados para a geração. Os genitais de uma pessoa estéril não são mais adequados para a geração do que uma arma com um percutor quebrado é adequada para atirar. $\mathrm{O}$ pino da arma pode ser reparado, talvez não; talvez a Medicina possa em alguns casos curar a infertilidade. Trata-se, entretanto, de um estiramento conceitual insistir que os atos sexuais dos incuravelmente inférteis são do mesmo tipo que os atos sexuais dos órgãos férteis que ocasionalmente falham em entregar os bens (KOPPELMAN, 2004, p. 21, tradução livre).

Parece-me que esta crítica não atinge de forma direta a concepção finnisiana de casamento no que diz respeito à ideia de união biológica. Pois como visto nos capítulos anteriores, a união biológica corresponde a um fim autoevidente da ação humana $\mathrm{O}$ casamento seria um bem humano básico porque seu fim duplo (a procriação efetiva ou tentada, e a amizade conjugal) são evidentemente e de forma indemonstrável fins básicos de uma ação humana que se pretenda racional. Enquanto conduta, a união biológica é a conduta necessária para a procriação, ainda que ela não ocorra por razões adversas à vontade do indivíduo. Dois homens ou duas mulheres não podem unir-se biologicamente, mas um homem e uma mulher sim. É por esta razão que um casal estéril poderia se casar ainda que esta união não corresponda ao significado focal de matrimônio, mas sim a um caso secundário ou periférico (FINNIS, 1998, p. 41-42). Em última análise, uma arma de fogo não deixa de ser uma arma de fogo (e portanto projetada para matar) porque não está carregada. De qualquer forma, acredito que a situação da esterilidade é bem resumida por Robert George (2010, tradução livre), nos seguintes termos:

[...] o fato é que as genitálias de homens e mulheres são sempre órgãos reprodutivos - mesmo durante períodos de esterilidade. Atos que preencham as condições comportamentais da procriação são reprodutivos em tipo mesmo quando condições não comportamentais da procriação não sejam obtidas. $\mathrm{Na}$ medida em que a finalidade ou objeto do intercurso sexual é a união marital, o parceiro encontra a união desejada (torna-se "um-só-corpo") precisamente enquanto eles encontram, ou se preferir, realizam o tipo de ato - o único tipo de ato - com o qual a dádiva das crianças possam surgir - o que no Direito tradicional e na Filosofia sempre se referiu, de forma intercambiável, como "o ato de geração" e "o ato conjugal".

Desse modo, creio que Finnis e os demais jusnaturalistas não são incoerentes quando defendem a possibilidade de casamento para os heterossexuais estéreis, mas excluem indivíduos homossexuais. A ideia de união biológica impede, ao menos formalmente, uma analogia entre o caso da esterilidade e a homossexualidade. O problema, entretanto, são as consequências que esta ideia traz quando estamos diante de casos como a intersexualidade e a transexualidade, situações mencionadas no primeiro capítulo. 
Estas consequências não passaram despercebidas por Macedo ou Koppelman. Macedo está atento a tais implicações quando cita o caso de um "gay" que faz uma cirurgia e passa a ter uma vagina ${ }^{87}$ :

\begin{abstract}
Isso levanta outras questões. Se a presença de um equipamento do tipo "certo" que não funcione é um elemento crucial para distinguir relações sexuais permissíveis, artifícios podem suprir o que a natureza não fez. Um homem gay pode fazer uma operação parcial de mudança de sexo, tendo seu pênis removido e uma vagina instalada. Isso permite ao casal gay recriar de forma suficientemente próxima a aparência de complementariedade biológica para terem um sexo valioso? (MACEDO, 1995, p. 10, tradução livre).
\end{abstract}

Já Koppelman sintetiza este ponto quando nos adverte do essencialismo presente na forma com que Finnis e outros autores concebem a função reprodutiva dos órgãos sexuais. Tal função não seria relevante nos termos de poder ou potência, mas apenas de forma taxonômica:

O NNL [New Natural Law] pode, finalmente, apelar para o essencialismo implicado pelo significado ordinário das palavras. O coração de um homem morto, embora nunca mais volte a bater, é ainda um coração, e seu estômago é ainda um órgão digestivo (por assim dizer! Não coloque lasanha nele). Da mesma forma o pênis de um homem estéril é ainda um órgão reprodutivo. Mas o único aspecto para a relevância da reprodução no argumento do NNL - o poder reprodutivo do órgão - não é inerente a este órgão peculiar. Ele não é reprodutivo no sentido de poder ou potência, mesmo se ele é um órgão reprodutivo no sentido taxonômico. É misterioso porque ele ser um órgão reprodutivo, de forma taxonômica, deveria ter qualquer significado moral (KOPPELMAN, 2004, p. 21-22, tradução livre).

Esta observação de Koppelman é interessante, pois em última análise demonstra que Finnis e outros autores elegem uma única "orientação" aos órgãos sexuais, limitando sua razão de ser à ideia de procriação ${ }^{88}$. É esta ideia que lhes permite, também, negar a moralidade de outros atos sexuais fora da união biológica e do casamento, assim como a

\footnotetext{
${ }^{87}$ Seria melhor que Macedo se referisse diretamente ao caso dos transexuais. Orientação sexual e gênero são questões distintas. Uma mulher transexual (ou seja, alguém que nasceu homem, mas "virou" mulher através da cirurgia de transgenitalização) pode, perfeitamente, sentir-se atraída por mulheres (e, nesta hipótese, seria "heterossexual").

${ }^{88}$ É o que se constata na réplica de Robert George, que afirma que um órgão reprodutivo, mesmo de um indivíduo estéril, prossegue sendo um órgão reprodutivo de fato e não apenas no nome (ou "taxonomicamente"). Em suas palavras: "For example, a hand is oriented toward grasping objects, and remains oriented toward that, even though a defect - a broken bone, for example - prevents it from actually doing so. Thus, a reproductive organ remains a reproductive organ in fact and not just in name (merely 'taxonomically'), even if some condition or defect in the agent makes actual reproduction impossible" (GEORGE, 2010). O que George parece se esquecer é que o fato de uma mão ser "orientada" para pegar objetos não significa que ela não possa ser orientada para outros fins, como saudar alguém. $\mathrm{O}$ mesmo pode ser dito dos órgãos sexuais: é certo que uma de suas razões é a procriação, através da "complementaridade" entre homem e mulher (que se uniriam em "um-só-corpo"), mas disso não se segue que eles podem também ser orientados para gerar o prazer em práticas que não se limitam à união biológica.
} 
masturbação, o uso de métodos anticonceptivos, dentre outros ${ }^{89}$. Tais atos feririam a própria integridade individual, tratando a existência corpórea como meio e não como fim.

Outra crítica interessante, levantada por Macedo, diz respeito ao lugar do prazer como um fim em si mesmo. Muitas vezes, por exemplo, comemos não apenas para saciar nossa fome, mas para fins de socialização ou por se tratar de uma atividade prazerosa - da mesma forma com que podemos mascar chicletes sem nos importarmos com seu valor nutritivo:

\begin{abstract}
Muitos também achariam profundamente irracional o julgamento de que o prazer não é um bem em si mesmo. Considere a analogia entre sexo e comer. Nós comemos e fazemos sexo não apenas para sustentar e reproduzir a vida humana, mas também por seu prazer intrínseco. Comer é uma atividade especialmente prazerosa quando compartilhada com outros (muitos pensam que o mesmo vale para o sexo): jantares sociais consolidam amizades, expressam afeto e assim adiante. Mas suponha que comer e se nutrir são separados. Comer pelo mero prazer natural é irracional? É permissível mascar chicletes, o que gera prazer, mas não tem nenhum valor nutricional, como questiona Andrew Koppelman, ou fazê-lo seria o equivalente gastronômico da masturbação (assumindo que nós não o fazemos para exercitar a mandíbula ou limpar os dentes)? Isso é imoral? (MACEDO, 1995, p. 11-12, tradução livre).
\end{abstract}

O ponto levantado por esta crítica é que, se podemos comer ou mascar um chiclete tendo em vista apenas o prazer gerado por tais condutas, não faz sentido limitar o ato sexual apenas à união biológica de fins procriativos. Dessa forma, o prazer sexual pode ser, também, visto como um dos fins razoáveis da ação humana, passível de experienciação tanto por heterossexuais quanto por homossexuais.

Não acredito que esta crítica esteja de todo incorreta, mas me parece que ela se esquece de um ponto fundamental, já mencionado: que é autoevidente que o sexo só pode corresponder a um fim básico da racionalidade humana quando dentro do casamento, na forma da união biológica. Logo, o sexo pode ser prazeroso, mas será imoral quando não atender à finalidade dupla do casamento - a procriação e amizade conjugal (FINNIS, 1998,

89 Para Macedo, este ponto enuncia a "irrelevância política" da moralidade sexual proposta por estes jusnaturalistas: "This fair-mindedness and broad sweep may also make the new natural law politically irrelevant. It supports only very broad public actions against sexual immorality in general: against divorce, contraception, all sex outside of marriage, and homosexuality. To reject natural law teachings on contraception, for example, is to jettison natural law ground for acting against homosexuality. This natural law philosophy cannot be of help to any but those few Americans who accept its extremely broad strictures. It provides no aid and comfort to the vast majority of those who would condemn homosexual activity while accepting the availability of divorce, contraception, and premarital sex" (MACEDO, 1995, p. 8). Particularmente, acho que neste ponto o jusnaturalismo acaba sendo relevante justamente por ser a forma mais coerente de se criticar a homossexualidade. E não apenas acerca da homossexualidade, mas todas as outras formas de "imoralidade sexual". Jusnaturalistas não estão preocupados com que as pessoas pensam ou acham do uso de anticoncepcionais, por exemplo - ao contrário, demonstram a incoerência destas pessoas que acreditam poder defender a pílula ou a camisinha, e ao mesmo tempo criticar o estilo de vida e o sexo homossexual. 
p. 20). Afinal, é através dele que se experiencia e se atualiza o bem do matrimônio, sendo sua inteligibilidade decorrente da inteligibilidade do bem do casamento (GEORGE, 2010). Quando nos afastamos desta inteligibilidade, tratamos nosso corpo como mero instrumento, buscando um fim que seria extrínseco ao matrimônio. Logo, restaria justificada a imoralidade do sexo que diferir da união biológica, não sendo possível a analogia com o prazer gastronômico ou o mascar de chicletes.

Em síntese, as críticas à concepção finnisiana de casamento que têm por alvo apenas a esterilidade de um ou ambos os cônjuges, ou o prazer como um dos fins da ação humana, acabam sendo externas ao tipo de raciocínio desenvolvido por Finnis e outros jusnaturalistas. Nunca é demais ressaltar que para tais autores o casamento (e seus fins de união biológica e amizade conjugal) é um bem inderivado, autoevidente, indemonstrado, indemonstrável e incomensurável. Ele corresponde a um bem humano básico.

Em partes anteriores deste trabalho foi apresentado o que isso significa, e mencionou-se uma das consequências deste tipo de raciocínio - a impossibilidade de se compor o debate, dada a insuficiência da concepção finnisiana de casamento em admitir a existência de controvérsias.

\subsubsection{Há bens mais básicos que o casamento? Controvérsias e evidências do erro metodológico de Finnis}

Percebe-se que o maior óbice para se reconhecer o casamento entre pessoas do mesmo sexo diz respeito à ideia de união biológica presente na concepção finnisiana. Casais de lésbicas e gays não são capazes de praticar atos de tipo reprodutivo. Trata-se de um fato incontestável. A questão central, entretanto, é a seguinte: se a união biológica (dentro da fides entre cônjuges) corresponde a um dos fins do casamento, e ela é inderivada, indemonstrada, indemonstrável, autoevidente e incomensurável, o que Finnis diria caso eu duvidasse da relevância da prática de atos de tipo reprodutivo enquanto elemento conceitual do casamento?

Esta é uma crítica que já foi levantada por outros autores. Em linhas gerais, corresponderia à afirmação de que o casamento não pode ser um bem humano básico, pois não resta claro que ele é autoevidente da mesma forma que a vida ou o conhecimento. De acordo com Finnis, esta crítica foi apresentada por Timothy Chappell nos seguintes termos: 
Nós não completamos qualquer explicação de uma ação afirmando que a ação a ser explicada é visando o casamento. É perfeitamente inteligível questionar porque o casamento é uma coisa boa, de uma maneira que não seria inteligível argumentar porque a amizade e o conhecimento são coisas boas. Além disso, o que transforma o casamento em uma coisa boa não é nada separado de sua instanciação de outros bens básicos, como, por exemplo, amizade, integridade, jogo, bem estético... saúde física e bem estar - e mesmo, se atreveriam a dizer, o prazer físico (CHAPPELL, 2001, p. 39 apud FINNIS, 2011b, p. 9, tradução livre).

Finnis responde esta crítica nos seguintes termos:

\begin{abstract}
A lista de bens que Chappell pensa explicar o bem do casamento conspicuamente omite o próprio bem que garante à amizade dos esposos seu ponto marital e seu comprometimento com a exclusividade permanente no compartilhamento do prazer sexual: sua orientação à procriação e à parentalidade (...) Conhecimento e amizade possuem todos os tipos de benefícios como meios para outros bens, benefícios os quais podem ser utilmente explicados enquanto se deixa sem explicação o seu bem intrínseco (conhecimento ou amizade, por seu próprio bem e apesar de cada custo e desapontamento) - sem explicação porque não precisa de explicação, mas apenas de alguma exemplificação suficientemente livre de distrações que permita que sua desejabilidade seja manifestamente inteligível. Da mesma forma, os benefícios de trazer à vida, e depois à maturidade, crianças que irão manter seus criadores e contemporâneos podem ser explicados utilmente ainda que se deixe sem explicação - e novamente sem necessidade de explicação, mas apenas de clara exemplificação o bem intrínseco da parentalidade, pela procriação igual e comum e pela dedicação apropriada na criação: o caso central do casamento (FINNIS, 2011b, p. $9 / 10$, tradução livre).
\end{abstract}

A resposta de Finnis à crítica de Chappell mostra-se muito interessante. Chappell afirma que o casamento não é um bem básico da mesma forma que o seriam a amizade e o conhecimento, pois acaba sendo derivado de outros bens humanos básicos como a própria amizade, o bem estar e até mesmo o "prazer físico". Se bem humanos básicos são inderivados, e o "bem" alcançado com o casamento resume-se a estes outros bens básicos, então o matrimônio não pode ser visto de acordo com a proposta finnisiana. Finnis, entretanto, afirma que o bem do casamento é único e inderivado porque a ideia de amizade entre os cônjuges não é independente de um ideal de procriação (seja ela "efetiva", o que configura seu caso central, ou "tentada" - a prática de atos de tipo reprodutivo por casais estéreis, que configuram casos periféricos). O bem intrínseco da procriação em um ambiente de amizade conjugal (e, por extensão, de atos sexuais de tipo reprodutivo em uma relação de fides entre homem e mulher) não depende de explicação. Ora, se este point duplo do casamento (que, a meu ver, só é concebido como "duplo" para facilitar sua análise analítica) é o que lhe dá sentido, então o próprio bem do casamento não depende de explicação. O casamento, para Finnis, corresponde à procriação (efetiva ou tentada) em um 
clima de união mental e espiritual, exclusiva e permanente, entre homem e mulher, e tal fato é intrinsecamente valioso, independente de qualquer explicação e apreendido através de uma "clara exemplificação".

O que Finnis diria caso eu duvidasse de sua posição, de que o sexo marital só pudesse corresponder à procriação ou atos de tipo reprodutivo em uma união de amizade exclusiva e duradoura entre homem e mulher? Em outras palavras, o que Finnis teria a dizer acerca de uma eventual controvérsia? Creio que, apoiando-se em sua interpretação de Tomás de Aquino, afirmaria o seguinte:

[...] A discussão de Aquino começa por apontar que algumas proposições são autoevidentes para "todos", uma vez que todos compreendem seus termos, [enquanto] outras proposições são autoevidentes apenas para os "sábios", uma vez que apenas os relativamente sábios (ou estudados) compreendem o que elas significam. Ele fornece dois exemplos do último tipo de proposição autoevidente, do campo da filosofia especulativa: um é que "o ser humano é um ser racional", e o outro é que "um espírito desencarnado não ocupa espaço". Ele então passa a falar sobre os princípios pré-morais autoevidentes que ele posteriormente denomina communissima, sem, infelizmente, indicar quais dentre eles acredita ser autoevidentes apenas para os relativamente sábios (FINNIS, 2011b, p. 32, tradução livre).

Em síntese, acredito que Finnis sustenta que o bem do casamento só se torna evidente para aquele que, de alguma forma, foi capaz de "experienciar" o valor intrínseco existente em uma relação de amizade conjugal marcada pela prática de atos de tipo reprodutivo - da mesma forma com que o valor da verdade só se tornaria óbvio para quem, em determinado momento, experienciou a conexão existente entre questão e resposta, que compreende que o conhecimento é constituído de respostas corretas para questões particulares, que de alguma forma desfruta da vantagem de alcançar respostas corretas. Uma criança recém-nascida, por exemplo, não possui estes tipos de inclinações, memórias, conhecimentos ou experiências. Por outro lado, quem os possui é capaz de observar que o conhecimento é, obviamente, um bem básico, sem necessidade de qualquer prova ou demonstração (FINNIS, 2011b, p. 65).

Logo, se eu sustentar que o casamento não corresponde àquilo que Finnis afirma ser, creio que sua réplica consistiria na afirmação de que eu não fui capaz de apreender o bem do casamento, ainda que seja capaz de compreender que outros bens humanos básicos são relevantes e consistam em fins racionais para a ação humana. Por uma série de "contingências da vida e do destino", eu não teria "experienciado" o bem do casamento, vislumbrado que a procriação e o cuidado dos filhos em um contexto de amizade conjugal são um bem em si mesmo, incomensurável, que independe de qualquer prova ou 
demonstração. Eu teria visivelmente me "esquecido", assim como Chappell, de que o casamento tem um point "marital".

Este ponto torna mais evidente o erro metodológico de Finnis, dada a sua impossibilidade de lidar satisfatoriamente com controvérsias teóricas. Ele faz uso daquilo que, já mencionado no capítulo anterior, Dworkin denomina "tese da incapacidade": ele só pode replicar minhas críticas e as de Chappell afirmando que não fomos capazes de "experienciar" o bem do casamento. Esta é, portanto, a principal crítica externa à posição de John Finnis, conferindo sentido às críticas já elaboradas por Stephen Macedo e Andrew Koppelman.

Por outro lado, resta clara a superioridade da posição dworkiniana quando notamos que o casamento não pode corresponder a um valor independente ou autônomo, pois na realidade ele é "derivado" de outros valores mais fundamentais - e estes poderiam ser vistos como bens humanos muito mais "básicos" do que o casamento (se adotarmos uma tipologia finnisiana) ou como "intrinsecamente valiosos" (como acredito que defenderia Dworkin). Apontar quais seriam tais bens ou valores intrínsecos corresponde a formular uma crítica interna à concepção finnisiana: é criticar finnisianamente a posição de Finnis, pois se trata de afirmar a "derivabilidade" do matrimônio.

Como mencionado em momentos anteriores deste trabalho, nós somos capazes de apreender os bens humanos básicos, enquanto fins racionais da ação humana, através da experiência. Creio que a interpretação de Germain Grisez sobre o primeiro princípio da razoabilidade prática, apresentado por Tomás de Aquino, fornece os meios para se defender a manifestação da sexualidade como uma inclinação humana e, consequentemente, um bem passível de conferir inteligibilidade às nossas ações. É interessante analisar esta interpretação, pois ela permite demonstrar a fragilidade e a pobreza da concepção finnisiana de "união biológica", bem como os equívocos de sua visão acerca da homossexualidade.

\subsection{O PRIMEIRO PRINCÍPIO DA RAZÃO PRÁTICA, AS INCLINAÇÕES HUMANAS E A MANIFESTAÇÃO DA SEXUALIDADE COMO UM BEM}

Tomás de Aquino é uma das principais influências no pensamento de John Finnis e de outros jusnaturalistas contemporâneos. Entretanto, sua obra não é das mais simples de serem compreendidas, existindo inúmeras interpretações divergentes. Dentre estas, uma das que considero mais interessantes é a formulada por Germain Grisez, que compartilha 
suas concepções (sobre casamento e homossexualidade, inclusive) com Finnis e Robert George.

Em um artigo de 1965 intitulado O Primeiro Princípio da Razão Prática, Grisez resgata a ideia de bem formulada por Tomás de Aquino de interpretações que considera equivocadas. Para muitos autores, o primeiro princípio da razão prática equivaleria a uma ordem ou um comando, que poderia ser expresso nos seguintes termos: "faz o bem e evita o mal". Este comando seria "inscrito nas consciências dos homens" por Deus, e o "bem" e o "mal” teriam uma conotação claramente moral (GRISEZ, 1965, p. 179-180).

Segundo Grisez, Tomás de Aquino concebe o primeiro princípio da razão prática em analogia ao primeiro princípio da razão teórica, que seria evidente e indemonstrável. A primeira distinção, portanto, versa sobre razão teórica e razão prática. Enquanto a primeira diz respeito àquilo que nosso intelecto é capaz de apreender, a razão prática está diretamente relacionada à apreensão natural de que toda ação tende a algo, tem um fim. A razão teórica diz respeito àquilo que "é", e a razão prática tem natureza finalística: corresponde a nossa mente "mapeando o que há de vir a ser" (GRISEZ, 1965, p. 187) ${ }^{90}$. Desse modo, o ser corresponde àquilo que, em primeiro lugar, pode ser apreendido de forma teórica pelo indivíduo, e o primeiro princípio indemonstrável da razão teórica é que uma coisa não pode "ser" e "não ser" ao mesmo tempo - não se pode afirmar e negar simultaneamente. O ser é o pressuposto e fundamento de inteligibilidade da ideia de razão teórica (GRISEZ, 1965, p. 182) ${ }^{91}$. Trata-se de algo evidente, apreendido naturalmente pela própria capacidade cognitiva humana.

Da mesma forma com que o ser está para a razão teórica, o bem está para a razão prática. Pois toda ação tem em vista um fim, e este fim é o que Tomás de Aquino entende por bem. Desse modo, o primeiro princípio da razão prática tem por fundamento a inteligibilidade natural da ideia de bem, ou seja, o bem é aquilo para que tende cada coisa. Segue-se que o primeiro princípio da razão prática, pode ser expresso da seguinte forma: $o$ bem deve ser feito e procurado, e o mal deve ser evitado (GRISEZ, 1965, p. 182). Por este

\footnotetext{
${ }^{90}$ É desse modo que Grisez define a razão prática: "Então, o que é a razão prática? É apenas o conhecimento buscado com finalidades práticas? Não, Tomas considera a razão prática como sendo a mente desempenhando um papel, ou funcionando em certa qualidade, a qualidade na qual ela é 'dirigida a uma obra'. A direção à obra é intrínseca à mente nesta qualidade: a direção qualifica o próprio funcionamento da mente. A razão prática é a mente operando como princípio da ação, não simplesmente como um recipiente da realidade objetiva. É a mente mapeando o que há de vir a ser, não simplesmente registrando o que é" (GRISEZ, 1965, p. 187).

91 "Ser é a inteligibilidade básica; ele representa nossa primeira descoberta sobre qualquer coisa que venhamos a saber - que é algo a se conhecer" (GRISEZ, 1965, p. 186).
} 
raciocínio, tem-se que o bem tem a inteligibilidade do fim, e o mal teria a inteligibilidade de contrário do fim.

Destas observações se segue que o bem não é um fim uno e indivisível. Se a inteligibilidade da ideia de bem decorre da apreensão de que toda ação tende a um bem, isso significa que a ideia de bem engloba tudo aquilo para onde a ação possa ser direcionada pela razão prática. Daí decorre que os fins de qualquer ação humana que se pretenda racional referem-se às inclinações naturais do ser humano. $\mathrm{O}$ objeto de uma inclinação humana, neste sentido, corresponderia a um bem básico.

Mas como apreendemos tais bens? O que torna possível afirmar que algo corresponda a uma inclinação natural do ser humano? Na compreensão de Grisez, para Tomás de Aquino a única maneira de apreendermos os bens básicos é através da experiência:

\begin{abstract}
A razão prática é a mente voltada para a direção, e ela dirige como pode. Mas ela só pode dirigir àquilo pelo que o homem pode ser levado a agir, e isto ou são os objetos de suas inclinações naturais ou são objetivos que delas derivam. Se a razão prática ignorasse o que é dado na experiência não teria força para dirigir, pois aquilo-que-há-de-ser não pode vir do nada. A direção da razão prática pressupõe as possibilidades sobre as quais a razão pode operar, e estas possibilidades surgem somente refletindo-se sobre a experiência. A operação que a razão tem nestas possibilidades expressa-se nos princípios substantivos básicos da lei natural (GRISEZ, 1965, p. 191).
\end{abstract}

Acredito, com as devidas cautelas, que a "experiência" corresponde ao nosso contato com o mundo, à nossa capacidade de conhecê-lo e de, através da razão prática, orientar nossas ações em direção àqueles fins que a própria razão dita serem possíveis de se alcançar. Para apreendê-los, não há qualquer derivação ou demonstração, assim como não há maneira de se derivar ou demonstrar o primeiro princípio da razão teórica (i.e., da não-contradição, de que uma coisa não possa "ser" e "não-ser" ao mesmo tempo) $)^{92}$.

É neste sentido, inclusive, que o bem não tem uma conotação moral, pois ele corresponde ao fim inteligível de qualquer ação ${ }^{93}$. Ele não é, necessariamente, uma "ação

\footnotetext{
92 “A razão prescreve de acordo com a ordem das inclinações naturais porque a razão dirige ações possíveis, e os padrões possíveis de ação humana são determinados por inclinações naturais, pois o homem não pode agir por conta daquilo para o que ele não tem nenhuma afinidade fundamentada nas suas inclinações" (GRISEZ, 1965, p. 192).

${ }^{93}$ Resta clara a influência do pensamento de Tomás de Aquino na teoria de John Finnis. Os bens humanos básicos mencionados por Finnis correspondem justamente àquilo que ele entende serem inclinações naturais do homem, e neste sentido que seriam "valores pré-morais". Entretanto, se estes bens são apreendidos através da experiência ou, se assim posso dizer, do contato com "as coisas como elas são", estes bens são muito mais variados. É por essa razão que as "listas" de bens humanos básicos apresentadas pelos jusnaturalistas são as mais variadas possíveis. Elas aparentam ser tentativas de "exemplificação", parecendo-me possível e coerente uma teoria de Direito Natural que prescinda de uma listagem dos bens básicos. Não é à toa que
} 
moralmente boa"; os bens básicos transcenderiam o bem e o mal morais, da mesma maneira que o fim transcende os meios e os obstáculos (GRISEZ, 1965, p. 195) ${ }^{94}$.

De qualquer forma, minha intenção ao recuperar a interpretação de Grisez sobre o primeiro princípio da razão prática é, justamente, demonstrar a centralidade que as inclinações naturais do homem e a sua experienciação ocupam quando definimos os bens humanos básicos - os fins que apreendemos de forma evidente, inderivada e indemonstrável no uso da razão prática.

Se mesmo para Finnis, apoiado em Tomás de Aquino, é através da experiência que apreendemos os bens humanos básicos, é de se duvidar que o casamento possa corresponder a um deles. De fato, Timothy Chappell acerta o alvo quando sugere que a experiência nos indica bens muito mais fundamentais do que o "casamento". O que se tem, a meu ver, é um erro crasso por parte de Finnis ao interpretar as inclinações humanas que possam formar bens humanos básicos.

Ao relacionarmos os bens humanos básicos com nossas inclinações naturais e nossa capacidade de experienciá-los, afirmando sua autoevidência, isso não significa que nossas interpretações sobre eles não possam ser alvos de críticas. Como sugere Robert George (1988, p. 1388-1389, tradução livre),

\footnotetext{
A afirmação de que eles são autoevidentes não implica que eles sejam incontestáveis ou, menos ainda, que ninguém possa negá-los. O que isso implica é que o intelecto prático pode compreendê-los, e o juízo prático pode afirmá-los, sem necessidade de derivação. ( $\mathrm{O}$ que não significa que eles possam ser compreendidos sem um entendimento acerca das realidades a que se referem).
}

Assim, acredito que o problema da concepção de Finnis decorra, antes de tudo, de sua explicação pobre e implausível sobre a sexualidade humana. Não há razão para limitála à prática de atos de tipo reprodutivo na medida em que, mesmo quando praticada na busca pelo prazer mútuo, ela é considerada valiosa pelas pessoas. Ora, creio que sejam poucas as pessoas que se sintam "instrumentalizadas" ao exercerem sua sexualidade de forma distinta da que Finnis considera "racional e moral". Nós consideramos a prática

Finnis afirma que outros autores podem discordar da lista que ele apresenta, mas ele "sugere" que quaisquer outros bens apresentados são, na realidade, derivações dos bens humanos básicos por ele indicados (FINNIS, 2011 b, p. 90).

94 "Para começar, Tomás, nega especificamente que o fim último do homem possa consistir na ação moral boa. A ação moral e aquilo a que se refere imediatamente podem dirigir-se a fins ulteriores e por isso a ação moral não pode ser o fim último de forma absoluta. Além disso, Tomás expressamente identifica os princípios da razão prática com os fins das virtudes preexistentes na razão. A prudência ocupa-se das ações morais que são de fato meios para fins, e a prudência dirige a operação de todas as virtudes morais. Portanto, os princípios da lei natural, em sua expressão de fins, transcendem o bem e o mal morais, da mesma forma que o fim transcende os meios e os obstáculos” (GRISEZ, 1965, p. 195). 
sexual importante, em suas inúmeras formas de manifestação (sejam heterossexuais ou homossexuais) justamente porque a sexualidade também consiste em uma inclinação natural na absoluta maioria das pessoas. E tanto melhor se ela for exercida em um clima de cumplicidade e afeto pelos parceiros, ocasião na qual há de se reconhecer que constitui um "bem" que qualquer pessoa legitimamente possa buscar.

Isso significa que, na realidade, sexo e procriação podem estar ligados materialmente, mas ontologicamente não se reduzem à mesma coisa. $\mathrm{O}$ sexo que não se limita à união biológica não corresponde, como imagina Finnis, apenas à busca hedonista do prazer. As diferentes maneiras em que se manifesta a sexualidade humana podem ser uma forma salutar de intimidade afetiva entre as pessoas - e é esta circunstância, ao invés do ideal procriativo, que a própria experiência demonstra ser evidente, inderivada e indemonstrável. Logo, antes da ideia de casamento, é manifestação da sexualidade que consiste em um bem humano básico aos padrões finnisianos, justamente por ser muito mais do que meros atos de tipo reprodutivo e, ainda assim, ter um valor intrínseco ${ }^{95}$.

Se não bastasse, o ideal procriativo finnisiano também diz respeito ao cuidado com os filhos, associando este ponto, de forma essencial, ao casamento. Mas isso não é correto: pois o valor do vínculo de parentalidade independe do vínculo matrimonial. Ninguém considera uma pessoa "órfã" de sua mãe na hipótese desta se tornar viúva, simplesmente porque a valiosa relação entre mãe e filho é independente do vínculo conjugal dos pais. Nós somos capazes de apreendermos o sentido da parentalidade fora de um contexto matrimonial, sem que ela seja derivada de uma concepção de casamento. Consequentemente, o que pretendo afirmar não é que um eventual ideal reprodutivo não seja importante, mas sim que ele não tem uma relação conceitual intrínseca com o casamento. Na realidade, assim como a sexualidade, pode-se sustentar que parentalidade corresponda a um bem humano básico, igualmente evidente, indemonstrável e inderivado.

\footnotetext{
95 José Reinaldo de Lima Lopes, a partir da distinção da filosofia clássica entre o agir e o fazer, afirma que a sexualidade se insere no campo das coisas que se fazem, e não as que se produzem: "Quando se age, a ação não se separa do sujeito: o que ele produz não é uma coisa, mas sua própria vida e sua própria forma de vida. A liberdade moralmente desejável diz respeito sobretudo à esfera dos agibilia. Na esfera dos factibilia o objeto mesmo pode impor-se ao sujeito e determinar suas escolhas. É o campo da técnica propriamente dita, que facilmente é dominado pelas regras de produção de um objeto. Ora, o campo dos agibilia é aquele em que as pessoas escolhem suas formas de viver, tanto na esfera pessoal quando na esfera comum. Isso significa que o campo da liberdade sexual está justamente nos agibilia e, por isso, é uma questão em última instância moral. Não é, porém, solucionável na forma da moral tradicional ou convencional. Esta é um instrumento fácil e necessário, mas não o critério último de julgamento. A crítica precisa ser feita, portanto, com um critério, e o critério limite é o da autonomia da pessoa, mas da autonomia de todas as pessoas envolvidas. A direção que nosso argumento toma é, pois, que a liberdade fundamental de cuidar de sua vida e conduzir sua atividade sexual é uma liberdade civil, fundada por seu turno na liberdade moral ou autonomia dos indivíduos" (LOPES, 2007, p. 53).
} 
Em última análise, também a relação entre mãe ou pai, e seus filhos, é intrinsecamente valiosa ${ }^{96}$.

A ausência de vinculação necessária entre sexo, procriação e casamento faz com que o matrimônio não possa corresponder, como sustenta Finnis, a um bem humano básico. Pois se é a sexualidade e a parentalidade que correspondem a bens básicos, independentes entre si no seu valor intrínseco, é simplesmente errado afirmar que o casamento é um bem evidente, indemonstrável e inderivado. Demonstrarei adiante que, na realidade, o casamento corresponde a uma forma de institucionalizar um vínculo entre duas pessoas que compartilham um tipo especial de afeto, gerando direitos e deveres, e é este afeto que corresponderia a um bem básico.

Antes, porém, é importante frisar que a sexualidade se manifesta das mais diversas maneiras. Ao contrário da interpretação finnisiana, o que a experiência demonstra é que algumas pessoas são "naturalmente" inclinadas não para a heterossexualidade, mas para a homossexualidade ou mesmo a bissexualidade. Enquanto algumas pessoas buscam não apenas relações sexuais, mas amor, carinho e afeto com pessoas de sexo distinto do seu, outras buscam com pessoas do mesmo sexo. Isto é uma observação empírica, que deve ser interpretada de forma adequada. Não há nada que diga que relacionar-se afetiva e sexualmente com alguém do mesmo sexo seja "errado", ou que venha a "ferir um bem humano básico" - simplesmente porque não faz sentido exigir de alguém que se comporte de forma distinta do que preceitua suas próprias inclinações, como sugere a interpretação de Grisez sobre o princípio da razão prática de Tomás de Aquino. Desse modo, mesmo que Grisez, Finnis, George ou até o próprio Tomás de Aquino cheguem a conclusões distintas, sustentando a imoralidade da homossexualidade ou das relações sexuais distintas da união biológica, tem-se que tais conclusões são equivocadas diante dos pressupostos revelados

\footnotetext{
${ }^{96}$ Este ponto se torna muito mais claro quando se constata que a "revolução sexual" do século XX, através dos métodos anticonceptivos, implicou em uma verdadeira mudança na maneira com que concebemos o matrimônio e as relações sexuais. Se não bastasse, a nova forma de se conceber o sexo, que passa a ser dissociado da ideia de casamento, implicou em debates sobre o aborto e as relações homossexuais. Como sugere José Reinaldo de Lima Lopes (1998, p. 54-55), “Assim como as descobertas da medicina dos séculos XIX e XX permitiram a expansão global da ocupação humana em escalas e locais antes não imaginados, a industrialização de contraceptivos e os tratamentos novos eliminaram uma série de hábitos e disciplinas sexuais que existiam exclusiva ou principalmente para se evitar a reprodução incerta. Naturalmente os resultados dessa mudança, muito recente, ainda não foram avaliados, e a mudança desses hábitos sofre de uma certa disjunção com relação à maturidade e experiência com que os indivíduos entram na vida sexual ativa. Os números a respeito de gravidezes indesejadas na adolescência são um exemplo de como a mudança social desvinculou sexo de família e reprodução não corresponde à mudança cultural e social em todas as classes e grupos sociais. A dissociação de atividade sexual da reprodução abriu a porta a dois campos em que a discussão da liberdade sexual, e dos direitos sexuais, se manifestou mais claramente: as relações entre pessoas do mesmo sexo e o aborto".
} 
pela experiência humana. Há um problema de incoerência interna na concepção finnisiana de casamento, o que nos permite criticar finnisianamente o próprio John Finnis.

Se a experiência demonstra que a racionalidade e a moralidade do sexo não se limitam aos atos de tipo reprodutivo, a ideia de "instrumentalização do corpo humano" através do sexo constitui outro equívoco da teoria finnisiana. Quando as pessoas fazem sexo, não me parece que o fazem (na maioria significativa dos casos) acreditando que ele é importante em razão da procriação. Casais estéreis conscientes desta condição certamente não o fazem por tal motivo. Mas ainda assim Finnis os considera casados porque eles “participam do bem do matrimônio", na perspectiva da amizade conjugal. E por acaso outras formas de união, como as homossexuais, estão impossibilitadas de participar deste ideal de amizade conjugal? Não há nada de "evidente" quando se afirma que a amizade conjugal esteja limitada apenas à união entre homem e mulher aliada à prática de atos sexuais de tipo reprodutivo.

Assim, mesmo a ideia de fides é mal concebida por Finnis. Como mencionado no primeiro capítulo, Finnis acredita que ela não tem razão de ser no caso dos homossexuais. Para ele, a impossibilidade de se praticar atos sexuais de tipo reprodutivo faz com que a ideia de exclusividade e permanência, típicas de sua concepção de amizade conjugal, não faça qualquer sentido entre lésbicas e gays. Dessa forma, ele questiona:

(...) qual é o caso central dos relacionamentos sexuais entre pessoas do mesmo sexo? Talvez o encontro anônimo na sauna, engajado tendo em vista sua repetição em outro cubículo mais tarde na noite. Talvez seja uma relação entre três ou quatro amigos estáveis e comprometidos entre si. Quem sabe? O que é claro é que (...) não há nada que demonstre porque uma ligação atual entre duas pessoas do mesmo sexo precisa ter a exclusividade e permanência no comprometimento que é inerente à ideia de casamento (incluído o casamento de casais estéreis) (FINNIS, 1998, p. 42, tradução livre)

Os exemplos indicados por Finnis sobre quais poderiam ser os "casos centrais" dos relacionamentos sexuais entre pessoas do mesmo sexo já sugere que, em sua visão, homossexuais possuem uma predisposição à promiscuidade. Na realidade, ele claramente acredita que homossexuais em geral padecem deste "vício". Em suas palavras:

Aqueles que propõe a ideologia "gay", ou teorias do casamento ou atividade sexual entre pessoas do mesmo sexo, não possuem bons princípios morais para oferecer contra a promiscuidade (prudente e moderada), a busca do orgasmo em qualquer toque amigável ou orifício acolhedor (humano ou não) que se pode oportunamente encontrar (...) $\mathrm{O}$ mundo dos relacionamentos entre pessoas do mesmo sexo (no mundo real, além dos artifícios do debate) não oferece 
exemplos genuínos, equivalentes ou homólogos do casamento, e apenas pouquíssimas imitações sinceras (FINNIS, 1998, p. 50, tradução livre).

Aqui também a experiência depõe contra as conclusões de Finnis e outros jusnaturalistas. Resta clara sua incapacidade de interpretar o próprio mundo em que vivemos, fonte das experiências que nos permitem acessar as inclinações humanas básicas e, portanto, os fins de uma ação humana racional. O erro de Finnis, aqui, corresponde a um verdadeiro erro factual. Ainda que haja diferenças pontuais no relacionamento entre duas mulheres, dois homens e entre um homem e uma mulher, o fato é que existe um número muito mais expressivo de semelhanças, as quais Finnis aparenta não estar disposto a enxergar. Há inúmeros casais de lésbicas e gays que permanecem juntos por muitos anos, em um envolvimento sexual, afetivo e com um plano de vida em comum - às vezes, mesmo no padrão finnisianamente valorizado do "até que a morte os separe". Logo, ele está pura e simplesmente errado ao afirmar que a fides, se compreendida como uma forma de "amizade conjugal", não pode existir entre homossexuais - ou, o que dá no mesmo, que ela consistiria apenas em uma "imitação" da que existiria em uma união heterossexual. Se não bastasse, se formos analisar as tais "diferenças pontuais" entre relacionamentos heterossexuais e homossexuais, verificamos que a igualdade de gêneros, muitas vezes, torna a relação muito mais igualitária na divisão de tarefas domésticas entre um casal de pessoas do mesmo sexo (o que, a meu ver, deve ser valorizado), do que em um casal heterossexual "padrão" - que, em certa medida, ainda se submete à tradicional e desigual concepção de que o homem é o mantenedor da família e a mulher é responsável pelos cuidados da casa e das crianças.

Tem-se que esta possibilidade de fides entre pessoas do mesmo sexo faz com que a relação sexual entre duas mulheres ou dois homens não se limite a uma "busca hedonista" do prazer. Assim como entre indivíduos heterossexuais estéreis, o sexo pode corresponder a uma forma de se estreitar os laços de intimidade, de constituir e aprofundar relações mais intensas, próximas e compromissadas. Como afirma Koppelman (1997, p. 7, tradução livre):

Para ao menos alguns casais de indivíduos do mesmo sexo, o intercurso sexual é valioso, não meramente como uma experiência prazerosa desintegrada do resto da vida de alguém, mas como uma atividade que é um elemento importante de uma das relações primárias da vida do indivíduo, exatamente como é o caso com muitos casais heterossexuais. Em um relacionamento sexual, homossexual ou heterossexual, a atividade de dar prazer mútuo tem o efeito real e pretendido de constituir uma relação que seja diferente e melhor - mais intensa, mais 
comprometida, próxima e mais duradoura - do que seria se os parceiros substituíssem, diga-se, a conversação

Em síntese, Finnis erra de forma evidente em suas interpretações sobre as inclinações humanas, ao menos que no que diz respeito à sexualidade. Isso faz com que ele sustente uma concepção incorreta de casamento, pois este não corresponde a um bem humano básico. Se não bastasse, constatando-se que a homossexualidade é uma inclinação básica de muitos indivíduos, não faz sentido que ela seja considerada, em si, imoral, até porque a compreensão que temos sobre o sexo não se limita à união biológica ${ }^{97}$. Deste ponto decorre, ainda, que a parentalidade também deve ser vista como um valor intrínseco que não se limita ao vínculo matrimonial.

\subsubsection{Outras questões e implicações da concepção finnisiana de casamento - II}

No primeiro capítulo, apresentei algumas implicações da concepção finnisiana de casamento, como as que dizem respeito ao divórcio, uso de anticoncepcionais, fertilização artificial e o caso dos intersexuais e transexuais. Agora, o leitor que eventualmente ficou incomodado com as provocações apresentadas naquele capítulo já consegue notar que, entendendo como insatisfatórias as respostas ou possíveis respostas oferecidas para tais questões, elas decorrem justamente da má compreensão finnisiana sobre a sexualidade humana e do fato de que o casamento não corresponde a um bem humano básico.

Desse modo, o divórcio seria justificável não como uma maneira através da qual o Direito "regulamenta" alguns pontos do Direito Natural, mas sim uma consequência de que o casamento é antes uma instituição do que um bem humano básico. Ademais, não deixa de se causar desconforto a ideia de que um bem humano básico possa ser "dissolvido" pela vontade das partes e com o aval do Estado, por mais que se empreendam todos os esforços argumentativos em sentido contrário.

O uso de anticoncepcionais também encontra uma resposta mais satisfatória quando desvinculamos o sexo da procriação, reconhecendo as diferentes formas de sexualidade

\footnotetext{
${ }^{97}$ Pode-se afirmar que a violência ou a agressividade também são comuns em muitos indivíduos, como verdadeiras inclinações, e são tidas como imorais. Mas mesmo que sejam vistas como ímpetos humanos, elas carecem de explicações que outras inclinações (como é o caso da curiosidade, que fundamenta o conhecimento) não dependem para serem compreendidas em sua autoevidência. Tratando da crueldade, Finnis afirma: "cruelty may be found to be an inverted form of pursuit of the value of freedom and selfdetermination and authenticity: some people may make themselves 'feel real' to themselves by subjecting others to their utter mastery. In the absence of such explanations, and of psycho-somatic disease, we find these urges as baffling as persistent illogicality, as opaque and pointless as, say, a demand for a plate of mud for no reason at all" (FINNIS, 2011b, p. 91).
} 
como intrinsecamente valiosas - o que faz com que não correspondam a uma "ofensa a um bem humano básico". Mesmo a fertilização artificial, ao menos em sua relação com a ideia de união biológica, fica muito mais simples de ser compreendida. Ainda assim, é curioso que Finnis não fornece uma resposta para a infertilidade masculina irreversível, não sendo claro se ele admitiria que o casal recorresse a um banco de sêmen ou à doação de um terceiro. $\mathrm{O}$ fato é que a desvinculação entre parentalidade e casamento faz com que estes pontos se tornem menos problemáticos.

Quanto aos intersexuais e transexuais, se minha argumentação em defesa de uma concepção ampla de sexualidade estiver correta, eles se encontram em posição semelhante à dos homossexuais, inexistindo razão para excluí-los conceitualmente do matrimônio e muito menos para considerá-los imorais. Algumas pessoas simplesmente nascem com características que impossibilitam seu enquadramento completo como "homem" ou "mulher", e tais indivíduos levam sua vida adiante e tem suas inclinações naturais assim como todos nós. O ponto é que, quando separamos o casamento da sexualidade, prescindimos do entendimento essencialista e taxonômico de união biológica - que, como afirmei, é atribuído por Koppelman à concepção finnisiana.

Por fim, a concepção de casamento de Finnis não responde outras questões que possam surgir. É concebível, por exemplo, a hipótese de um homem casado que se torna sexualmente impotente e que, ainda assim, permanece convivendo com sua esposa. O que aconteceria neste caso? Se o "sexo marital", como Finnis sustenta, é tão relevante a ponto de ser visto como uma questão de "justiça" (FINNIS, 1998, p. 17/18) a sua impossibilidade superveniente implicaria no fim do enlace matrimonial? O casamento teria se transformado em uma mera relação que subsistiria sobre o epíteto do bem da amizade? Justificar-se-ia o divórcio?

Obviamente, eu não me contentaria com uma eventual resposta de que o homem impotente pode recorrer ao Viagra ou outra forma de combate à disfunção erétil. Sustentar isso seria desmerecer o raciocínio filosófico - afinal, não é implausível a situação de um homem casado que venha a se tornar irreversivelmente impotente. Se o point do casamento, para Finnis, corresponde à fides entre os cônjuges, que só pode ser compreendido de maneira indissociável à prática de atos sexuais de tipo reprodutivo, o casamento perderia sua razão de ser para o homem em questão.

Se levarmos em consideração a concepção de casamento sustentada por Finnis, esta é uma questão insolúvel. E se ele tentasse resolvê-la, certamente a resolveria mal: se levarmos à risca a lógica do raciocínio finnisiano, este homem não poderia mais 
"participar" do bem do casamento e, na melhor das hipóteses, manteria um relacionamento de amizade (o que não se confunde com uma amizade conjugal) com sua mulher ${ }^{98}$, podendo buscar sentido em sua vida através de outros bens humanos básicos e fundamentais.

De qualquer forma, não adiantaria afirmar que o relacionamento em questão se assemelharia à de um casal estéril enquanto um "caso periférico" de casamento: mesmo a situação matrimonial do casal estéril só é vista como tal através da possibilidade prática de atos sexuais de tipo reprodutivo. Para Finnis, não há como conceber conceitualmente o casamento diante da impossibilidade de se praticar atos sexuais de tipo reprodutivo. $\mathrm{O}$ mesmo problema poderia ser dito com relação aos casais de idosos que não mais conseguem "participar” do casamento através da união biológica.

Outro ponto que causa perplexidade na posição de Finnis diz respeito ao incesto. Assim como o divórcio, Finnis (2007, p. 17) entende que as relações incestuosas são proibidas em decorrência dos limites deixados pelo Direito Natural às autoridades, políticas ou eclesiásticas, para que regulamentem os limites e algumas implicações do bem do casamento. O fato é que, se considerarmos apenas a concepção finnisiana de matrimônio, não há qualquer impedimento para que parentes consanguíneos possam se casar (e.g., irmão e irmã, que podem inclusive se "unirem biologicamente"). Este é um ponto particularmente curioso, porque George, Girgis e Anderson (2010, p. 250) a apontam como uma falha para concepções liberais de casamento - que eles denominam "revisionistas", como se verá mais adiante.

Percebe-se, portanto, que Finnis e os demais jusnaturalistas não possuem uma boa concepção de casamento. Eles falham ao não perceber o que a própria experiência indica com clareza: que a sexualidade e suas variadas formas de manifestação são inclinações naturais dos indivíduos. Tal fato acarreta as críticas e implicações aqui analisadas. Mas uma vez analisada e criticada a concepção finnisiana, pretendo agora elaborar minha própria concepção de casamento, que corresponde a uma concepção interpretativa, de matizes dworkinianos. Minha primeira constatação é que o matrimônio corresponde a uma instituição, de modo que se faz necessário explorar o que isso significa ${ }^{99}$.

\footnotetext{
98 Esta me parece ser a única solução possível para o caso em questão. Em diversas passagens, inclusive citadas ao longo deste trabalho, Finnis afirma que os indivíduos não apenas "participam" do casamento, mas o "atualizam" através de atos sexuais de tipo reprodutivo. Consequentemente, a união biológica deve subsistir ao longo de toda a relação matrimonial, pois não consiste apenas em um elemento que configura sua gênese - o casamento não apenas surge com a prática de atos sexuais de tipo reprodutivo, mas também é mantido através de tais atos.

${ }^{99}$ Devo este insight às observações formuladas por José Reinaldo de Lima Lopes.
} 


\subsection{O QUE SERIA, ENTÃO, O CASAMENTO?}

\subsubsection{O casamento como instituição}

Para compreender o que significa uma instituição acredito que seja interessante analisar a concepção desenvolvida por John Searle, tomando por base o quinto capítulo de seu livro Mente, linguagem e sociedade (2000) e seu artigo What is an institution? (2005).

Uma das preocupações de Searle é explicar de que maneira criamos uma realidade social e institucional objetiva. O que faz, por exemplo, com que os papéis que guardamos em nossas carteiras sejam “dinheiro"? A primeira constatação é que estes papéis só são dinheiro porque os aceitamos como tal, da mesma maneira com que outras realidades sociais e institucionais também dependem, ainda que não inteiramente, de aceitação coletiva. Se não bastasse, o fato de se atribuir ao dinheiro uma função faz com que seu detentor tenha uma série de poderes que, de outra maneira, não teria. $\mathrm{O}$ mesmo se passa com a própria ideia de "propriedade": ter um automóvel gera ao seu "titular" uma série de direitos e deveres, que de outra maneira não existiram ${ }^{100}$. Mas não se pode explicar que um pedaço de papel é dinheiro apenas porque acreditamos que seja dinheiro. Devemos verificar qual é o conteúdo desta crença sem recorrer ao próprio conceito de dinheiro, pois do contrário cairíamos em circularidade ou regressão infinita (SEARLE, 2000, p. 107).

É possível constatar, então, que o dinheiro só é dinheiro não apenas porque o aceitamos como tal, mas pelas funções que ele exerce em nossa vida coletiva. Dinheiro, propriedade e até mesmo o casamento são o que são porque atuam causalmente em nos sas vidas (SEARLE, 2000, p. 108). Mas é interessante notar que estes "fatos" atuam em nossas vidas de forma distinta, por exemplo, da força gravitacional. Eles não correspondem a fatos naturais - não são, portanto, “independentes dos observadores". Antes disso, eles estão diretamente ligados a uma intencionalidade que faz com que sejam relativos aos observadores (SEARLE, 2000, p. 110). Desse modo, fatos como o dinheiro ou o

100 “(...) um tipo de coisa só é dinheiro a longo prazo se for aceito como dinheiro. E o que se aplica ao dinheiro aplica-se à realidade social e institucional em geral. Assim, dinheiro, linguagem, propriedade, casamento, governo, universidade, festas, advogados, presidentes dos Estados Unidos são todos, em partemas não inteiramente -, assim descritos porque os consideramos dessa maneira. Um objeto se encaixa em uma dessas descrições, em parte, porque pensamos que of faz, ou o aceitamos e reconhecemos como tal. (...) Além disso, o fato de considerarmos que esses fenômenos se encaixam em determinada descrição acarreta consequências importantes: devido ao fato de que eu e outras pessoas pensarmos que o pedaço de papel em meu bolso é dinheiro, tenho certos poderes que de outra maneira não teria. E o que é verdade para o dinheiro é verdade para a realidade institucional em geral" (SEARLE, 2000, p. 106). 
casamento não são como raios ou nuvens no céu; eles só existem porque são instituições, dependentes dos observadores (ou, melhor dizendo, dos indivíduos em geral que vivem em

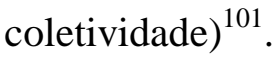

Mas ainda resta saber como uma instituição pode corresponder a uma realidade epistemologicamente objetiva ${ }^{102}$, ainda que sua ontologia seja dependente dos observadores e, portanto, tenha um elemento ontologicamente subjetivo (SEARLE, 2000, p. 110) ${ }^{103}$. Em outras palavras, como somos capazes de criar a partir de nossas crenças e intenções uma realidade de conceitos como dinheiro e empresas, sobre os quais podemos formular afirmações objetivamente verdadeiras (SEARLE, 2005, p. 4)? O que faz com que um fato como casamento seja capaz de gerar direitos e deveres? O que o torna, em síntese, uma instituição?

Para compreendermos o que seja uma instituição, é interessante verificarmos o que constitui um fato institucional (SEARLE, 2005, p. 9). Neste sentido, Searle alerta para ao menos três elementos necessários para que possamos dizer que um fato é institucional: intencionalidade coletiva, atribuição de funções e funções de status.

A intencionalidade coletiva é apreendida a partir da constatação de que somos capazes de desenvolver uma intencionalidade do tipo "nós temos a intenção", "nós esperamos", dentre outras (SEARLE, 2000, p. 112) ${ }^{104}$. Ela pressupõe a nossa capacidade de cooperação, gerando um fato social:

Sempre que tivermos pessoas cooperando, teremos intencionalidade coletiva. Sempre que tivermos pessoas compartilhando seus pensamentos, sentimentos e outros temos intencionalidade coletiva; e, de fato, o que quero dizer é que esta é a base de todas as atividades sociais. (...) Definirei fato social, de maneira arbitrária, como qualquer fato que envolva dois ou mais agentes que possuem

\footnotetext{
${ }^{101}$ Searle $(2005$, p. 3) afirma que um bom teste para saber se um fenômeno é independente ou relativo ao observador corresponde a perguntar se o fenômeno teria existido se não existissem seres humanos conscientes e dotados de intencionalidade em suas ações.

${ }^{102}$ De acordo com Searle (2005, p. 4), uma afirmação seria epistemologicamente objetiva quando a sua veracidade ou falsidade puder ser estabelecida a partir de fatos independentes dos sentimentos e atitudes daqueles que formulam ou interpretam a afirmação.

103 Algo teria uma ontologia subjetiva quando sua existência depender da "experienciação" por sujeitos humanos ou animais: "Thus, for example, pains, tickles and itches, and human and animal mental events and processes generally, exist only insofar as they are experienced by human or animal subjects. Their mode of existence requires that they be experienced by a human or animal subject”' (SEARLE, 2005, p. 4).

${ }^{104}$ Searle acredita que as abordagens filosóficas que sustentam que a intencionalidade coletiva reduz-se à intencionalidade individual são confusas. Elas "supõe que, quando duas pessoas compartilham uma intenção coletiva, como quando tentam fazer alguma coisa juntas, cada qual tem uma intenção na forma 'eu tenho a intenção', mais uma crença a respeito da intenção do outro" (SEARLE, 2000, p. 111). A ideia de crenças mútuas acaba gerando uma regressão infinita ("eu acredito que você acredita que eu acredito..."). Mas é plenamente factível conceber a "intencionalidade do nós" dentro de nossas mentes: "não há nada que nos impeça de ter em nossas cabeças individuais, por exemplo, intencionalidades da forma 'nós acreditamos', 'nós temos a intenção' e outras”' (SEARLE, 2000, p. 112).
} 
intencionalidade coletiva. Então, por exemplo, animais caçando juntos, pássaros cooperando na construção de um ninho e provavelmente os chamados insetos sociais, como formigas e abelhas, manifestam intencionalidade coletiva e, portanto, geram fatos sociais (SEARLE, 2000, p. 113).

É curioso que, além da cooperação capaz de gerar fatos sociais, dentro da intencionalidade coletiva, nós também somos capazes de atribuir funções a determinados objetos. O segundo elemento necessário para que possamos falar em instituições, portanto, corresponde à atribuição de funções. Em certa medida, mesmo outros animais são capazes de atribuir funções a determinados objetos, como os gravetos utilizados por castores na construção de barragens. Quando combinamos a intencionalidade coletiva com a atribuição de funções, percebemos que podem existir atribuições coletivas de funções (SEARLE, 2005, p. 7) ${ }^{105}$.

Mas é o terceiro elemento que nos permite falar não apenas em fatos sociais, e sim em fatos institucionais. Diferente de outros animais que atribuem funções a determinamos objetos em razão de suas características físicas, nós somos capazes de atribuir funções de status - o que corresponde, para Searle, ao terceiro elemento para que exista um fato institucional. Isso significa dizer que a função de determinado objeto (ou mesmo indivíduo) não precisa decorrer de uma característica física, mas de um status atribuído por coletivamente. Este é um ponto muito importante, e Searle o demonstra a partir de um exemplo que se tornou conhecido nos debates conceituais sobre instituição - o da construção de um muro de pedras por um conjunto de indivíduos que vivem em grupo:

O muro tem uma função atribuída em virtude de suas características físicas.
Suponhamos que o muro é alto demais para poder ser escalado, e que os
habitantes do abrigo podem facilmente impedir tais escaladas. Reparem que o
muro, conforme foi descrito até agora, tem duas das características que
mencionamos anteriormente como essenciais para a realidade institucional. Ele
tem a atribuição de função e a intencionalidade coletiva. Uma função - a função
de agir como barreira - foi atribuída ao muro pelos habitantes, coletivamente.
Estamos supondo que o muro foi construído por eles num esforço cooperativo,
de maneira a poder cumprir sua função. Então, a esses aspectos desejo
acrescentar um terceiro. Quero variar ligeiramente a história de maneira que,
espero, soe inocente mesmo que dela dependa um enorme conjunto de fatores.
Suponhamos que o muro apodreça gradualmente. Ele se deteriora lentamente até
que tudo o que resta é uma linha de pedras. Mas suponhamos que os habitantes

105 É curioso que, neste sentido, as funções são relativas aos observadores. Muitas vezes, entretanto, descobrimos "funções" na natureza, como a do coração em bombear sangue. Para Searle (2000, p. 114), "é só porque partimos do pressuposto de que a vida e a sobrevivência devem ser valorizadas que podemos dizer que a função do coração é bombear sangue, querendo dizer que, na ecologia geral do organismo, bombear sangue serve para assegurar a vida e a sobrevivência”. Não é difícil tecer uma analogia entre este ponto com a posição finnisiana sobre a união biológica: em última análise, Finnis atribui uma única "função" aos órgãos genitais em razão da valorização que atribui à procriação. Decorre daí que a "função" do sexo, por excelência, seria reprodutiva. 
continuem a tratar a linha de pedras como se ela pudesse desempenhar a função do muro. Suponhamos que, naturalmente, eles tratem a linha de pedras como se compreendessem que ela não deve ser cruzada. (...) Agora, como eu disse, quero que essa história pareça inocente, mas acredito que uma mudança muito importante aconteceu em razão desse acréscimo. Essa mudança é um movimento decisivo para a criação da realidade institucional (SEARLE, 2000, p. 117).

O que se observa é que, se os indivíduos não transpõe a linha de pedras, o fazem não por suas características físicas, mas sim pelo fato de que o muro deteriorado passou a ter uma função atribuída coletivamente na forma de um status.

Esses elementos nos permitem falar na existência de fatos institucionais. Particularmente, a atribuição de funções de status implica no reconhecimento de que somos capazes de criar e constituir algumas atividades através do que se entende como regras constitutivas. Elas diferem das regras regulativas na medida em que não visam regulamentar comportamentos pré-existentes, mas sim torná-los possíveis. O exemplo clássico, neste sentido, é o jogo de xadrez: "a própria possibilidade de jogar xadrez depende da existência das regras de xadrez, porque jogar xadrez é agir de acordo com pelo menos um determinado conjunto considerável de regras de xadrez. Chamo tais regras de 'regras constitutivas",' (SEARLE, 2000, p. 115).

Regras constitutivas possuem uma forma geral do tipo "X equivale a $\mathrm{Y}$ " ou, mais precisamente, "X equivale a Y em (no contexto) C" (SEARLE, 2005, p. 7-8; 2000, p. 116). A partir daí, tem-se que uma instituição corresponde a um conjunto de regras constitutivas deste tipo, provendo uma estrutura através da qual se torna possível criar fatos institucionais. (SEARLE, 2005, p. 10).

É importante ressaltar que a função de status de um objeto ou alguém carrega uma deontologia, ou seja, cria o que Searle denomina poderes deônticos (deontic powers) direitos, deveres, obrigações, autorizações etc (SEARLE, 2005, p. 10). Desse modo, por exemplo, em um relacionamento familiar posso ser detentor de direitos e obrigações enquanto me é atribuído o status de pai ou de filho, considerando que tais relações são institucionalizadas na forma de relações de poder e autoridade:

Pense em tudo o que você se importaria em mencionar - propriedade privada, governo, relações contratuais, assim como relações informais como amizade, família e clubes sociais. Tudo é uma questão de direitos, deveres, obrigações etc. Eles são estruturas de relações de poder. Frequentemente, os fatos institucionais envolvem fatos naturais. Assim, há uma família biológica consistente nos pais e sua prole biológica. Mas humanos impuseram a esta biologia subjacente uma estrutura institucional mais elaborada, formal e informalmente, envolvendo os respectivos status de mãe, pai, e filhos. Nas assim chamadas "famílias estendidas", relações de autoridade e outras funções de status podem incluir não 
apenas pais e filhos, mas vários outros parentes. Além disso, dadas as estruturas institucionais, podem existir famílias com pais e filhos onde estes não são biologicamente relacionados entre si (SEARLE, 2005, p. 10-11, tradução livre).

Ao atribuirmos funções de status para determinados objetos e indivíduos, que geram tais poderes deônticos, tem-se que as instituições não têm por propósito limitar as pessoas, mas sim criar novos tipos de relações de poder. O reconhecimento destas novas formas de relação de poder faz com que as instituições sejam capazes de criar novas razões para a ação humana, na medida em que criam novos desejos - como a vontade de ficar rico ou de obter um doutoramento (SEARLE, 2005, p. 11) ${ }^{106}$.

Mas nem sempre basta a mera "aceitação coletiva" para que algo corresponda a um fato institucional. Como visto, fatos institucionais podem ser gerados por instituições, que por sua vez são constituídas de regras constitutivas que, ao seu turno, tem sua razão de ser em funções de status atribuídas coletivamente, que correspondem também a fatos institucionais. O que se constata é que há interpenetrações complexas entre os próprios fatos institucionais, e entre as inúmeras regras constitutivas e instituições daí decorrentes (SEARLE, 2000, p. 121). Isso faz com que, em muitas ocasiões, a própria constituição de uma instituição dependa de uma instituição pré-existente. Não há como se falar em impostos, por exemplo, sem pressupor a instituição do Estado.

Mas diante de tais esclarecimentos, o que faz com que o casamento corresponda a uma instituição?

Em primeiro lugar, observamos que um casamento pode surgir a partir de um conjunto de fatos institucionais, cujas funções de status podem ser reiteradas indefinidamente, como sugerido pelo próprio Searle (2005, p. 8, tradução livre) ao exemplificar a construção de estruturas institucionais:

\footnotetext{
Assim, por exemplo, quando eu faço determinados sons através da minha boca, fazendo com que tais sons contem como proferir sentenças em Inglês; mas proferir tais sentenças em Inglês conte como fazer uma promessa; e, neste contexto, fazer uma promessa conte como realizar um contrato. Fazer este tipo de contrato neste contexto conta como casar-se, e assim adiante.
}

A ideia de casamento, portanto, só é factível diante de um contexto social marcado por fatos institucionais. Ele corresponderia a uma instituição, capaz de gerar outros fatos

\footnotetext{
106 "By creating private property, governments, marriages, stock markets, and universities, we increase the human capacity for action. But the possibility of having desires and satisfying them within these institutional structures - for example, the desire to get rich, to become president, to get a Ph.D., to get tenure - all presuppose that there is a recognition of the deontic relationships" (SEARLE, 2005, p. 11).
} 
institucionais, na medida em que é formado por inúmeras regras constitutivas. Isso ocorre porque sua existência como tal está imersa em um contexto muito mais amplo de fatos institucionais, regras constitutivas e outras instituições. Prova disso está na necessidade de que o casamento seja "reconhecido" por outra instituição (ou, melhor dizendo, por uma autoridade), seja ela eclesiástica ou estatal, para que venha a gerar direitos e deveres. Estas instituições estabelecem verdadeiras regras constitutivas do matrimônio, como a necessidade de manifestar a vontade de se casar de forma pública, livre e desimpedida, diante da autoridade competente (e.g., um padre ou um juiz de paz).

Uma vez casado, há algumas maneiras de se reconhecer este status. Searle sugere a existência de alguns indicadores de status (status indicators), como seria o caso dos anéis de noivado e das certidões de casamento (SEARLE, 2005, p. 15). O mais relevante, entretanto, está no reconhecimento de que o indivíduo casado submete-se a uma série de deveres e passa a ter direitos que de outra forma não teria.

O interessante é que ao conferir tais poderes deônticos o casamento funciona de forma análoga às outras instituições, gerando desejos e criando razões para a ação. Isso faz com que muitos busquem se casar porque o status de casado gera tais relações deônticas, que por sua vez são reconhecidas como tal pelas outras pessoas e instituições. Não é à toa que namoros possam se converter em matrimônios: a união entre duas pessoas, ainda que originalmente pautada apenas no afeto, pode gerar um plano de vida em comum marcado por expectativas recíprocas que, sem o reconhecimento do status de "casados", dificilmente seriam protegidas no caso de rompimento da relação. As pensões previdenciárias pagas ao cônjuge sobrevivente, ou o direito de pleitear alimentos no caso de divórcio, são exemplos claros de poderes deônticos que só podem ser exercidos em razão do casamento.

Consequentemente, é no reconhecimento de que o casamento corresponda a uma instituição capaz de gerar direitos e deveres que somos capazes de entender uma das razões que levam lésbicas e gays a lutarem pelo matrimônio. Ela não é a única razão porque, como demonstrei em momentos anteriores deste trabalho, o casamento também versa sobre valores intrínsecos aos seres humanos, notadamente a inclinação básica que todos somos capazes de compartilhar com o outro, independentemente de nosso gênero ou orientação sexual: o afeto e o desejo de construir uma vida em comum. Não se trata de mero sentimentalismo, mas do reconhecimento, oriundo da própria experiência, de que tanto heterossexuais quanto homossexuais são capazes de se relacionarem sexual e afetivamente, 
e que destes relacionamentos possam surgir uma complexa rede de expectativas mútuas, demandantes de proteção jurídica através do reconhecimento estatal.

Acredito que pontos que eventualmente ficaram obscuros neste trabalho agora restam mais claros. Apresento gradualmente argumentos que, unidos, formam uma concepção de casamento. Finnis está incorreto não apenas porque é incapaz de conceber razoavelmente a sexualidade humana, mas porque acredita que o casamento é um bem humano básico e porque obscurece sua perspectiva institucional. O jogo de xadrez não é um bem humano básico, mas a experiência que ele é capaz de instanciar sim - nós jogamos xadrez porque temos uma inclinação natural às atividades lúdicas (i.e., vemos tais atividades como um bem básico a ser buscado em nossas ações, e o xadrez é uma forma de alcançá-lo). Algo semelhante se passa com o casamento: ele não é um bem humano básico, mas uma instituição que versa diretamente sobre inclinações humanas e valores intrínsecos. Obviamente, não há necessidade de se casar para somente então ser capaz de amar alguém ou criar um plano de vida em comum. Mas, como se viu, o casamento é uma instituição capaz de potencializar tais fatos ao criar relações deônticas que, ao seu turno, geram desejos e expectativas que de outra maneira não existiriam. Quando as pessoas se casam, elas tem em vista o valor e o simbolismo do matrimônio $e$ os direitos e deveres que ele acarreta, para a proteção de uma vida em comum.

É importante ressaltar que o reconhecimento do casamento como uma instituição não invalida o argumento anteriormente formulado, de que o matrimônio homossexual não se trata de uma questão meramente semântica. Na realidade, não faz sentido algum criar uma "instituição análoga" ao casamento para lésbicas e gays, com os mesmos direitos e deveres, se tanto heterossexuais quanto homossexuais possuem a mesma inclinação ao afeto e à sexualidade, sendo que apenas a manifestam de forma distinta. Admitir outra instituição além do casamento para minorias sexuais, ainda que contemple seus anseios de ordem material, simboliza um tratamento desigual diante de relações que, em sua essência, tem o mesmo fim. Como sustentei anteriormente, o casamento não deve ser atrelado à procriação, muito menos à ideia de união biológica, considerando que o valor intrínseco da parentalidade existe e não se confunde com o matrimônio - ninguém deixa de ser pai ou mãe por não ser casado.

Ressaltada a natureza institucional do casamento, resta agora verificar qual valor ou valores podem compor uma concepção desta instituição. Ainda que muitas vezes sejam vistos como inclinações naturais ou intrinsecamente valiosos, estes valores devem ser 
analisados interpretativamente (e de forma integrada, portanto) com outros valores que compartilhamos socialmente.

\title{
3.3.2. Uma concepção interpretativa de casamento
}

Robert George, Sherif Girgis e Ryan Anderson sugerem, em seu artigo intitulado What is Marriage? (ANDERSON; GEORGE; GIRGIS, 2010) a existência de duas visões opostas sobre o que vem a ser o casamento. A primeira delas corresponde à visão conjugal:

\begin{abstract}
Visão conjugal: o casamento é a união do homem e da mulher que constroem um compromisso mútuo permanente e exclusivo do tipo que é naturalmente (inerentemente) cumprido através da nutrição e criação conjunta de filhos. Os esposos selam (consumam) e renovam sua união por atos conjugais - atos que constituem a parte comportamental do processo de reprodução, que os une em uma unidade reprodutiva. O casamento é valioso em si mesmo, mas sua orientação inerente à nutrição e criação de filhos contribui para sua estrutura distinta, incluindo normas de monogamia e fidelidade. Este vínculo com o bem estar dos filhos também ajuda a explicar porque o casamento é importante ao bem comum e porque o Estado deve reconhecê-lo e regulamentá-lo (ANDERSON; GEORGE; GIRGIS, 2010, p. 246, tradução livre).
\end{abstract}

Não é difícil perceber que a concepção finnisiana de casamento se alinha a esta perspectiva "conjugal". Inclusive, esta é a perspectiva adotada por George, Girgis e Anderson ao longo de seu artigo. Na medida em que já analisei pormenorizadamente as razões pelas quais, conceitualmente, esta é uma visão equivocada do casamento, entendo ser interessante analisar aquilo que os autores denominam de visão revisionista:

\footnotetext{
Visão revisionista: o casamento é a união entre duas pessoas (do mesmo sexo ou de sexo oposto) que se comprometem ao amor romântico e ao cuidado mútuos, e ao compartilhamento dos encargos e benefícios da vida doméstica. Ele é, essencialmente, uma união de corações e mentes, aprimorada por quaisquer formas de intimidade sexual que ambos os parceiros considerem aceitáveis. $\mathrm{O}$ Estado deve reconhecer e regular o casamento porque ele tem um interesse nas parcerias românticas estáveis e nas necessidades concretas dos esposos e de quaisquer crianças que eles escolham criar (ANDERSON; GEORGE; GIRGIS, 2010, p. 246/247, tradução livre).
}

Acredito que esta perspectiva é uma das melhores formas de se conceber o matrimônio. Ela elenca valores que, a meu ver, efetivamente tratam o casamento como um conceito interpretativo nos moldes dworkinianos. Já que desconheço qualquer trabalho de Dworkin que trate de forma específica os valores que ele acredita constituírem o point do casamento, me parece que esta é uma perspectiva através da qual posso construir minha própria concepção. 
A ideia de "amor romântico" sugerida pela visão revisionista me parece ligada ao valor do afeto. O valor da afetividade, neste sentido, é um dos elementos centrais do enlace matrimonial. Se não bastasse, ele é visto mesmo pela civilística brasileira como um dos elementos fundamentais para se conceber a ideia de família. Se esta era classicamente vista como um conjunto de relações voltadas para a defesa de um "indivíduo-proprietário", atualmente as relações familiares "passam a defender o indivíduo enquanto ser dotado de sentimentos e voltado para a concretização de relações afetivas” (LAGO, 2012, p. 273/274).

De qualquer sorte, no que diz respeito especificamente ao casamento, a ideia de afeto pressupõe um enlace que o particulariza. Assim, nós conseguimos entender que dois amigos possam manter uma relação de "afeto", mas veríamos essa relação de forma distinta na hipótese de se tratar de uma afetividade que envolva um grau diferente de intimidade (como na hipótese de se manterem relações sexuais) ou de se elaborar planos para o futuro, visando uma vida em comum - o que sugere, por exemplo, que se trata de um casal de namorados.

Dessa forma, me parece acertado falar na existência do afeto como um dos principais valores englobados pela instituição matrimonial. Nós percebemos como valiosa a união afetiva entre duas pessoas que compartilham de uma vida comum - e, porque não dizer, percebemos tais relações como intrinsecamente valiosas. Não se trata, mais uma vez, de mero sentimentalismo: as pessoas tendem, em alguns momentos de suas vidas, a se apaixonar e a compartilhar suas vidas de maneira solidária. Trata-se de algo que a própria experiência nos mostra. Somos capazes de nos apaixonarmos e sofremos os arroubos do amor da mesma forma com que somos naturalmente inclinados à busca pelo saber.

Esta afetividade, como é de se perceber, também nos inclina a compartilhar uma vida de planos em comum marcada pela solidariedade. A posição da civilista Maria Celina Bodin de Moraes sintetiza a questão:

\footnotetext{
A solidariedade do núcleo familiar compreende a solidariedade recíproca dos cônjuges e dos companheiros, principalmente quanto à assistência moral e material. O lar é, por excelência, um lugar de colaboração, de cooperação, de assistência, de cuidado; em uma palavra, de solidariedade civil. O casamento, por exemplo, transformou-se de uma instituição autoritária e rígida em pacto solidário (MORAES, 2008, p. 239).
}

É importante ressaltar que, dentro desta perspectiva, a prática de atos sexuais pode sinalizar a existência de uma relação marcada por este tipo de afetividade, mas sua 
inocorrência não significa que um casal não possa se casar. Muitos casais de idosos não mais fazem sexo, e nem por isso deixam de viver em clima de cumplicidade e solidariedade. O mesmo vale para aqueles indivíduos que, considerando-se assexuais, eventualmente são capazes de manifestar este tipo especial de afeto por alguém.

De qualquer forma, acredito que na maioria significativa dos casos o afeto que propicia namoros e, posteriormente, casamentos, é acompanhado de atração sexual. O contato físico através de relações sexuais é capaz de proporcionar maior cumplicidade e intimidade ao casal, seja ele heterossexual ou homossexual. O ato sexual é valioso na medida em que é a manifestação, por excelência, de nossa sexualidade - uma inclinação básica e valor intrínseco. Talvez aqui a ideia finnisiana de significado focal seja particularmente útil: manifestar a sexualidade através de atos sexuais integra o que poderíamos chamar de "caso central" deste tipo de afeto, enquanto valor que a instituição do casamento busca proteger. Hipóteses onde as relações sexuais são ausentes podem configurar "casos periféricos" deste afeto, o que certamente não significa que elas não possam ser tuteladas através do matrimônio.

As ideias de afeto, solidariedade e de um plano de vida em comum correspondem aos valores que o casamento busca tutelar e concretizar. Sem eles, não é possível apreender seu sentido, pois mesmo sendo uma instituição, o casamento não deixa de ter um significado valorativo.

Prova disso são os casos em que o reconhecimento do status de casado tem em vista garantir a uma das partes apenas proveitos de ordem econômica. É a hipótese de uma pessoa idosa ou adoentada que, nas vésperas da morte, pretende "beneficiar" alguém com uma pensão bancada pelo Estado. Diz-se que, em tais casos, trata-se de um "casamento simulado", ainda que celebrado perante a autoridade estatal com todos os rigores de ordem formal. Quando isso ocorre, não há que se falar em casamento, e não apenas por inexistir a intenção de se construir um plano de vida em comum: por mais nobres que sejam os sentimentos de alguém em beneficiar outra pessoa (e.g., gratidão com a enfermeira que acompanhou seus últimos instantes), este acaba sendo um caso de ofensa ao bem comum, consubstanciado na lesão ao patrimônio público.

O mesmo se pode dizer dos casos de "casamento forçado", visando reunir o patrimônio de duas famílias, que foram muito comuns ao longo dos séculos e que ainda ocorrem em algumas sociedades. O nosso horror diante destes casos decorre justamente da afronta à liberdade do individuo, no sentido de poder escolher livremente com quem 
pretende se relacionar e construir uma vida em comum. Esta liberdade é um pressuposto básico das relações de afeto.

A declaração de nulidade aos "casamentos" deste tipo evidencia que a instituição do matrimônio não tem em vista qualquer tipo de relação, mas apenas aquelas relações marcadas por um conjunto de valores, como a vontade de estar ao lado de alguém, construir uma vida comum afetiva de forma solidária, e proteger as expectativas e projetos criados mutuamente. Não se trata apenas de direitos e deveres, ou de meras expectativas patrimoniais: cônjuges não são meros sócios em uma sociedade empresária. O casamento é um dos exemplos básicos de uma instituição familiar, e atualmente não conseguimos conceber razoavelmente a ideia de família sem atentar para a afetividade, para um tipo de relação intersubjetiva que demanda um reconhecimento específico por parte dos demais.

É curioso que, no caso brasileiro, o casamento convive ao lado da união estável como formas de união civil. No Brasil, casamento e união estável são instituições que protegem, basicamente, os mesmos valores da afetividade e solidariedade familiar. Ontologicamente, entendo que não há maiores diferenças entre ambos, tirando as questões de ordem jurídica. Ambos são vistos como uniões familiares e englobam os mesmos valores. Ambos correspondem à união de duas pessoas que vivem solidária e afetivamente.

A única distinção entre ambos está na sua forma de constituição. Trata-se de instituições cujas regras constitutivas são ligeiramente diferentes. Enquanto o casamento é celebrado, iniciando-se a partir de então, a união estável não tem termo de início estabelecido (DIAS, 2009, p. 162) ${ }^{107}$ - e daí falar-se em reconhecimento de união estável. Não é à toa que não é possível ser juridicamente casado com duas pessoas ao mesmo tempo (i.e., a bigamia), mas é possível reconhecer a união estável de alguém casado, mas separada de fato (ou judicialmente) - como se observa no art. $1.723, \S 1^{\circ}$ do Código Civil.

O fato é que, tanto no casamento quanto na união estável, os indivíduos envolvidos buscam criar uma vida em comum, marcada pela solidariedade e afetividade. As diferenças não são propriamente de definição conceitual quanto aos seus fins, mas pura e simplesmente de tutela legislativa - o que gera reflexos negativos no imaginário popular, que prossegue vendo o casamento como a união civil por excelência. Em que pese a equiparação constitucional com o casamento, a união estável permanece com tratamento diferenciado na legislação infraconstitucional. Não é por outro motivo que muitos civilistas consideram equivocada tal diferenciação e equiparem o casamento e a união estável em

${ }^{107}$ Como menciona Maria Berenice Dias (2009, p. 162), a união estável "nasce da consolidação do vínculo de convivência, do comprometimento mútuo, do entrelaçamento de vidas e do embaralhar de patrimônios". 
seus efeitos jurídicos e materiais. Neste sentido, Maria Berenice Dias (2009, p. 162/163) sustenta que:

\begin{abstract}
O casamento e a união estável são merecedores da mesma e especial tutela do Estado. Todavia, em que pese a equiparação constitucional, a lei de forma retrógrada e equivocada outorgou à união estável tratamento notoriamente diferenciado em relação ao matrimônio (...) Quando a lei trata de forma diferente a união estável em relação ao casamento, é de se ter simplesmente tais referências como não escritas. Sempre que o legislador deixa de nominar a união estável frente a prerrogativas concedidas ao casamento, outorgando-lhe tratamento diferenciado, devem tais omissões ser tidas por inexistentes, ineficazes e inconstitucionais.
\end{abstract}

É importante destacar que a distinção entre casamento e união estável não tem qualquer relação com a ideia de que possa haver uma "união civil especial" para homossexuais, reservando-se o casamento apenas aos heterossexuais. Como visto, a diferença entre casamento e união estável está em sua forma de constituição. Logo, é possível reconhecer a união estável tanto de casais homossexuais quanto heterossexuais, mas não faz sentido celebrar uma "união civil especial" para homossexuais e o casamento para heterossexuais ${ }^{108}$. Conceber uma união civil homossexual distinta do casamento, como argumentei em diversos momentos deste trabalho, é tratar o tema de forma meramente taxonômica.

De qualquer sorte, minha preocupação central ao formular esta concepção de casamento, que toma por base primordialmente o que entendo serem os valores do afeto e da solidariedade, é demonstrar que mesmo homossexuais podem, conceitualmente, se casar. Como sustentei, este afeto, a solidariedade e a vontade de se construir uma vida em comum são valores que compartilhamos socialmente e que não correspondem a uma exclusividade de heterossexuais. O mais interessante é perceber que a ideia de afeto e solidariedade possam ser vistas tanto como inclinações, como bens a serem buscados racionalmente em nossas ações, quanto valores intrinsecamente valiosos - sendo possível estabelecer, neste ponto, uma conexão entre as formas com que Finnis e Dworkin concebem o valor. A diferença é que, neste caso, tais valores não são importantes de modo autônomo, mas integrado. Assim como a amizade, eles são importantes porque tornam

\footnotetext{
${ }^{108}$ Se considerarmos a evolução da "união homossexual" no Brasil, percebemos que ela começou em verdadeira situação de "marginalidade jurídica", para posteriormente ser vista jurisprudencialmente como uma sociedade de fato. Depois, com a decisão do Supremo Tribunal Federal nas ADPF 132 e ADI 4.277, como uniões estáveis. Por fim, tem-se a Resolução no 175 do Conselho Nacional de Justiça (CNJ), de 14 de maio de 2013, que impede a recusa por parte dos cartórios na celebração do matrimônio entre pessoas do mesmo sexo ou a conversão em casamento da união estável homoafetiva - o que, na prática, corresponde à "legalização" do casamento homossexual no país. Esta trajetória se assemelha com a que resultou nas uniões estáveis
} 
nossa vida melhor e mais valiosa, e não como coisas separadas ou fixadas de forma independente das nossas preocupações em se viver bem (DWORKIN, 2006b, p. 156).

Tais considerações demonstram a vantagem da teorização dworkiniana. Se analisarmos o casamento enquanto conceito interpretativo, como sugere Dworkin, percebemos que diante de uma pluralidade de concepções é possível encontrar uma que seja mais adequada e coerente às nossas práticas e valores compartilhados. Uma concepção que não apenas explique o que é o casamento, mas que justifique as razões que o tornam importante e valioso, sem descurar do fato de que se trata de uma instituição. Neste sentido, uma boa concepção de casamento não pode elevá-lo à categoria de bem humano básico indemonstrável, autoevidente ou incomensurável (ainda que os valores que o compõe, eventualmente, possam ser vistos como tais). É importante demonstrar argumentativamente nossas convicções, as razões que fazem o casamento ser o que defendemos que ele seja.

\subsubsection{Implicações desta concepção de casamento}

Mas minha concepção de casamento não seria abstrata demais? De que maneira ela responderia, por exemplo, a questão da poligamia? Trata-se de uma questão que George, Girgis e Anderson (2010, p. 272) levantam para aqueles que subscrevem a visão revisionista do casamento.

Meu objetivo foi sustentar que homossexuais tem um direito moral ao casamento, e até aqui apresentei uma concepção de matrimônio que permite abrangê-los conceitualmente. De qualquer sorte, tenho que admitir que inexiste qualquer razão conceitual plausível, em minha concepção de casamento, para impedir que mais de duas pessoas possam se casar. Afinal, seria impossível conceber a existência de um afeto e de planos de vida em comum compartilhados, em um clima de solidariedade, por mais de duas pessoas? A própria experiência, a realidade em que estamos inseridos, não sugere casos em que isso é possível? ${ }^{109}$

\footnotetext{
${ }^{109}$ George, Girgis e Anderson sustentam que, em última análise, um revisionista coerente deveria admitir a possibilidade do casamento poligâmico, ou aceitar a validade da visão conjugal: "Any revisionist who agrees that the state is justified in recognizing only real marriages must either reject traditional norms of monogamy and sexual consummation or adopt the conjugal view - which excludes same-sex unions (...) [W] challenge the many revisionists who support norms, like monogamy, as a matter of moral principle to complete the following sentence: Polyamorous unions and nonsexual unions by nature cannot be marriages, and should not be recognized legally, because..."
} 
A concepção de Finnis claramente exclui as relações poligâmicas, mas demonstrei que o fundamento para esta exclusão (a ideia de união biológica) é descabido. De qualquer forma, creio que este trabalho comprova a importância de que os argumentos contrários e favoráveis ao casamento homossexual sejam argumentos justificados racionalmente, e isso vale igualmente para a perspectiva de um casamento poligâmico. Desta maneira, a metodologia que deve ser seguida para a compreensão desta possível forma de casamento é semelhante à que aqui empreendo. É necessário demonstrar a coerência e a validade racional não apenas dos argumentos favoráveis à poligamia, mas, sobretudo, dos argumentos contrários. Afinal, se for constatado que os argumentos contrários à poligamia não se sustentam (da mesma forma com que não se sustentam os argumentos de Finnis contra o casamento homossexual), o que justificaria sua rejeição do ponto de vista conceitual? Em qualquer dos casos, o casamento não deixa de ser uma instituição cujo sentido deva ser buscado interpretativamente, em relação aos valores que compartilhamos, particularmente aqueles que consideramos intrinsecamente valiosos. Não será possível que nossos valores, em última análise, não sejam mais bem compreendidos de maneira a se justificar, também, o casamento poligâmico? ${ }^{110}$

Outro problema que George, Girgis e Anderson (2010, p. 250, tradução livre) levantam diz respeito à questão das relações incestuosas:

\begin{abstract}
Muitos revisionistas afirmam que existem diferenças importantes entre estes casos e as uniões entre pessoas do mesmo sexo. O incesto, por exemplo, pode gerar crianças com problemas de saúde e envolver o abuso de menores. Mas então, se assumirmos que o interesse estatal em evitar estas consequências ruins supera o que os revisionistas tendem a descrever como um direito fundamental, por que não permitir os casamentos incestuosos entre adultos inférteis ou casais de indivíduos do mesmo sexo? Os revisionistas podem responder que as pessoas podem livremente entrar em tais relacionamentos, em todos ou alguns dos outros listados, mas estes não merecem reconhecimento legal. Por quê? Porque, e o revisionista será forçado a admitir, o casamento enquanto tal não pode assumir estas formas, ou o pode apenas de forma imoral. Reconhecê-los seria diferente, confuso ou imoral.
\end{abstract}

Esta também é uma questão particularmente interessante. Certamente, o incesto constitui um tabu desde tempos imemoriais, e a análise da questão acaba sendo muito mais

\footnotetext{
${ }^{110}$ Um possível argumento contrário é de que, tradicionalmente (ou "historicamente") a poligamia sempre se apresentou na forma "um homem e várias mulheres". Assim, o casamento poligâmico seria símbolo de uma sociedade machista e uma ofensa aos interesses das mulheres. Entretanto, não me parece que este argumento se sustente de um ponto de vista estritamente racional. Ora, não é possível que uma mulher tenha o interesse em partilhar sua vida com mais de um homem (ou com mais de uma mulher)? Neste caso, não seria injusto que esta mulher, se assim o desejar, não possa se casar com mais de um homem apenas porque se entende que, para outras mulheres, a poligamia implicaria em um contexto indesejável para a vida familiar?
} 
delicada do que a da poligamia. Mas tenho que reconhecer que minha concepção não oferece uma resposta satisfatória mesmo para este ponto. Creio, todavia, que a metodologia para a análise de um eventual casamento incestuoso passe por muitas questões semelhantes às que trato no presente trabalho. Será inconcebível que irmã e irmão, por exemplo, não possam compartilhar o afeto conjugal? Como visto, mesmo a concepção de Finnis não responde esta questão. Irmãos, enquanto homem e mulher, podem praticar atos de tipo reprodutivo, independentemente da geração de filhos saudáveis ou não (assim como casais estéreis). Também não é inconcebível que este relacionamento se dê em um âmbito de amizade conjugal, na fides. Logo, o que faria com que relações incestuosas heterossexuais não pudessem resultar em um casamento, mesmo dentro da concepção finnisiana, que curiosamente é a adotada por George, Girgis e Anderson?

Estas questões, assim como outras que poderiam surgir, certamente mereceriam um cuidado mais aprofundado. Em qualquer hipótese, entretanto, espero ter demonstrado que uma relação homossexual também pode ser abrangida, conceitualmente, pelo casamento. Este representa o primeiro e imprescindível caminho que devemos trilhar antes de afirmarmos que o casamento pode e deve ser reconhecido como um direito moral dos homossexuais, o que será defendido no próximo capítulo. 


\section{O CASAMENTO COMO DIREITO MORAL DOS HOMOSSEXUAIS}

Do fato de que uma concepção de casamento possa abranger casais homossexuais não decorre que deva ser reconhecido para lésbicas e gays um direito moral ao casamento. Como mencionado, o casamento possui uma perspectiva institucional e isso se relaciona diretamente com a avaliação moral e jurídica da questão. Afinal, ninguém contesta o fato de que indivíduos heterossexuais têm direito ao casamento, mas a questão se torna controversa quando se trata de indivíduos homossexuais. E as razões levantadas para excluir homossexuais não se resumem apenas ao sentido de "casamento", mas também à (i)moralidade da homossexualidade e suas relações com o papel do Estado diante de questões afetas à autonomia e a liberdade individual.

Minha intenção neste último capítulo é desenvolver estes pontos que vão além da perspectiva conceitual do casamento, ainda que de forma relativamente breve e não exauriente. Eles não são o objeto fundamental deste trabalho, mas esta reflexão se faz necessária caso se pretenda defender o casamento como um direito de lésbicas e gays, a ser reconhecido pelo Estado - o que, em última análise, não deixa de integrar meu objetivo principal.

De certa forma, acredito que o tema já estaria esgotado pela constatação, arguida no capítulo anterior, de que a sexualidade e sua manifestação correspondem a uma inclinação natural das pessoas, que não é em si mesma "boa" ou "ruim" - antes, constitui um "bem", um princípio e (ao mesmo tempo) um dos fins possíveis, inteligíveis e racionais da ação humana. Nela se encontra incluída a homossexualidade. Mas isso não deixa de forma evidentemente clara o dever do Estado de tratar todos os indivíduos com igualdade de consideração e respeito, razão pela qual algumas considerações ainda se fazem necessárias.

\subsection{AS RELAÇÕES ENTRE DIREITO E MORALIDADE - O DEBATE HART- DEVLIN-DWORKIN}

Creio que a análise do debate desenvolvido entre Herbert Hart e Patrick Devlin contribui para as questões levantadas. O debate, que ocorreu em meados dos anos 60 a partir das obras The Enforcement of Morals (1975), de Devlin, e de Law, Liberty and Morality (1963), de Hart, refere-se à descriminalização da prática de atos sexuais de 
natureza homossexual na Inglaterra, bem como da prostituição, e toma por base as conclusões do relatório elaborado pela Comissão Wolfenden. O argumento elaborado por referida comissão é de que relações homossexuais consentidas entre adultos se inserem no âmbito da moralidade privada, que não poderia ser objeto de avaliação legal. Neste sentido, defende-se a existência de um âmbito de moralidade e imoralidade privadas que não dizem respeito ao Direito, razão pela qual a homossexualidade deveria ser descriminalizada.

Devlin, entretanto, sustenta que a sociedade se mantém coesa não apenas em razão de um governo, mas principalmente pelo compartilhamento de uma moral comum - que ele atribui, no caso dos países Ocidentais, aos valores cristãos, pois religião e moral seriam indissoluvelmente ligadas (DEVLIN, 1965, p. 4). Seria por tal razão que questões como eutanásia, suicídio, aborto e incesto seriam apreciados pelo Direito, ainda que realizados no âmbito privado e sem ofensa a terceiros (DEVLIN, 1965, p. 7). Assim, Devlin (1965, p. 11, tradução livre) sintetiza sua posição da seguinte forma:

\begin{abstract}
Se a sociedade não tem direito à formulação de julgamentos sobre a moral, o Direito precisa encontrar alguma justificação especial para entrar no campo da moralidade: se a homossexualidade e a prostituição não são em si mesmas coisas erradas, então o ônus é claro sobre o legislador que pretende criar uma lei contra certos aspectos destas, para justificar o tratamento excepcional. Mas se a sociedade tem o direito de formular um julgamento moral, e o tem com a base de que uma moralidade reconhecida é tão necessária quanto, por exemplo, um governo reconhecido, então a sociedade pode usar o Direito para preservar a moralidade da mesma forma que o utiliza para salvaguardar qualquer coisa que seja essencial para sua existência.
\end{abstract}

Consequentemente, Devlin sustenta que não há limites para o Estado legislar contra a imoralidade. A sociedade se desintegraria se uma "moral comum" não fosse observada e, por tal razão, a sociedade estaria justificada para preservar seu código moral da mesma forma que preserva seu governo e outras instituições fundamentais (DEVLIN, 1965, p. 13). Tal "moral comum" seria apresentada a partir da visão do "homem médio" ou do "homem razoável" - que, para Devlin, não se confunde com o "homem racional" (1965, p. 15). Isso não significa pura e simplesmente a "vontade da maioria", ou que uma maioria simplesmente desaprova determinada conduta (como seria o caso da homossexualidade). Entretanto, para Devlin, a repugnância (disgust) que muitas pessoas sentem pela homossexualidade seria um claro indicativo de que os "limites da tolerância" teriam sido alcançados, e a sociedade não tem que tolerar tudo (DEVLIN, 1965, P. 17). Dessa forma, 
desapaixonada, nós a consideramos um vício tão abominável que sua mera presença é uma ofensa. Se este é o sentimento genuíno da sociedade em que vivemos, eu não vejo como pode ser negado à sociedade o direito de erradicá-la (DEVLIN, 1965, p. 17, tradução livre).

Em síntese, Devlin acredita que a homossexualidade (ainda que praticada no âmbito privado), considerando a forte repulsa que pode gerar no homem comum, constitui uma ofensa à moralidade social que não precisa ser tolerada. E sendo a moralidade comum um dos elementos que mantém a sociedade coesa, esta última estaria justificada em criminalizar as condutas que afrontam esta moralidade e que, neste sentido, atentem à sua própria existência.

Esta posição foi duramente criticada por Hart. Para ele, Devlin falha ao desconsiderar a importância de uma moral crítica. Ao lado de uma moral social (denominada "moral positiva"), que constitui uma moral aceita e compartilhada por um grupo social, existem princípios morais gerais utilizados para a crítica das instituições que constitui o que ele denomina moral crítica (HART, 1963, p. 20).

Dentre estes princípios gerais, Hart elenca a necessidade de serem apresentadas justificações ao uso da coerção jurídica no plano da moralidade. A mera repulsa do "homem médio" não consistiria em uma justificativa racional à criminalização da homossexualidade e, portanto, a análise moral apresentada por Devlin seria acrítica (LOPES, 2005, p. 68). Ocorre que, da mesma forma com que são apresentadas justificativas para a punição de criminosos, entendemos que a restrição da liberdade através da obediência de determinadas normas jurídicas também deva ser alvo de justificação. Dessa forma, segundo Hart (1963, p. 22) é necessário apresentar uma justificação racional àqueles cujos desejos são frustrados por medo da punição, o que assume particular relevância na hipótese de leis coercitivas que tomam por base a moral sexual. Pois:

\footnotetext{
Ao contrário dos impulsos sexuais, o impulso para roubar ou para lesionar, ou mesmo matar, não é, salvo numa minoria de casos de anormalidade mental, uma constante e insistente parte da vida diária. A resistência à tentação de perpetrar esses crimes não é frequente; o mesmo não se dá com a supressão dos impulsos sexuais, porquanto se apresentam como algo que afeta o desenvolvimento ou o equilíbrio da vida emocional do indivíduo, sua felicidade, sua personalidade (HART, 1987, p. 48).
}

A relevância da justificação, em meu entender, reside justamente na constatação de que "os impulsos sexuais" (i.e., a sexualidade) estão em direta relação com as possibilidades que todo indivíduo tem para realizar-se, ter uma vida plena e feliz. Trata-se 
de uma inclinação do ser humano, como defendi no capítulo anterior, inclinação esta que é distinta de impulsos como roubar e matar. Desse modo, como alerta José Reinaldo de Lima Lopes ao interpretar este trecho, "Hart sugere que a tentativa de controlar os impulsos sexuais e a tentativa de controlar os impulsos de roubo ou mesmo de assassinato dizem respeito a objetos (os impulsos) muito diferentes" (LOPES, 2007, p. 68).

De qualquer modo, Devlin não oferece nenhuma evidência de como a homossexualidade corresponderia a um perigo à existência da sociedade. Ele trata como um fato a afirmação de que "desvios da moral social compartilhada" são capazes, por sua natureza, de ameaçar tal existência (DWORKIN, 1966, p. 992). De qualquer forma, as manifestações da sexualidade, onde se insere a homossexualidade, influenciam nossas concepções de família. Dia após dia são levantadas questões como a de adoção por homossexuais e, como é o caso deste trabalho, do casamento entre pessoas do mesmo sexo. Isso demonstra que a homossexualidade não está restrita ao âmbito privado, mas que por constituir um elemento intrínseco da personalidade de muitos indivíduos, é externalizada e repercute na esfera social - gerando questões de ordem prática. Assim o legislador será, inevitavelmente, confrontado com questões de ordem moral ao defender determinados tipos de instituições, e tal fato poderá significar a restrição de liberdades individuais (DWORKIN, 1966, p. 993). A defesa da concepção finnisiana de casamento, implicaria, obrigatoriamente, na impossibilidade de estender o direito ao casamento para os homossexuais - em outras palavras, homossexuais não seriam livres para se casar.

Como sustentei ao longo do trabalho, esta concepção e outras que limitam o casamento às uniões heterossexuais não se sustentam. Mas isso não se reflete de forma direta nas relações entre a sociedade e os indivíduos homossexuais. Como se deve interpretar, por exemplo, a eventual vontade de uma maioria contrária aos direitos de lésbicas e gays? Devlin diria que o legislador deve decidir de acordo com a vontade desta maioria (o que ele trata por "princípio democrático"), pois a decisão deve ser antes política do que moral (DEVLIN, 1965, p. 78).

No Brasil, segundo pesquisa do IBOPE publicada em 28 de junho de 2011, mais da metade dos brasileiros é contrária ao casamento homossexual ${ }^{111}$. Neste sentido acredito que a análise da posição de Devlin se faz interessante, sendo apressado considerar sua posição superada apenas pelas críticas apresentadas por Hart. É conveniente, portanto,

111 Os dados da pesquisa podem ser conferidos no site do referido instituto, no seguinte link: <http://www.ibope.com.br/calandraWeb/servlet/CalandraRedirect?temp=5\&proj=PortalIBOPE\&pub=T\&db =caldb\&comp=IBOPE+Inteligência\&docid=639993E9DDC6DC32832578DA00603AEE $>$. Acesso em 24 de março de 2012. 
retornarmos à Dworkin. Em seu artigo Lord Devlin and the Enforcement of Morals (1966), Dworkin critica a posição de Devlin acerca das crenças ou convicções morais dos indivíduos.

Para Devlin, como visto, a repulsa do homem comum poderia constituir um elemento relevante para justificar o caráter imoral da homossexualidade e deveria ser levada em consideração pelo legislador. Dworkin, entretanto, analisa criticamente a ideia de "posição moral" e sustenta a existência de algumas regras fundamentais do raciocínio moral que limitam os tipos de justificativas consideradas válidas ou inválidas - excluindo preconceitos e gostos pessoais (DWORKIN, 1966, p. 995). Os indivíduos devem apresentar razões que fundamentem suas posições, com a finalidade de convencer os demais de que sua posição é uma posição moral. Logo, ainda que as pessoas acreditem que o indivíduo esteja errado, deverão respeitar sua posição, reconhecendo ao menos sua coerência, pois estaria de acordo com as regras socialmente compartilhadas do raciocínio moral (DWORKIN, 1966, p. 995).

Mas nem todos os fundamentos apresentados serão, de fato, "racionais". Dworkin elenca quatro tipo de razões frequentemente apresentadas pelos indivíduos contrários à homossexualidade que, dada sua natureza, não podem alicerçar uma posição moral coerente. São eles: a) o preconceito, uma vez que não consideramos válidos os argumentos que pressupõe a inferioridade de alguém em razão de sua raça, gênero ou orientação sexual; b) as reações emocionais, considerando que o que os indivíduos sentem (repugnância, nojo) deve ser fundamentado por razões morais, e não o contrário; c) as considerações de fato falsas ou implausíveis, como a crença de que a homossexualidade gera terremotos, não são consideradas justificativas moralmente válidas por desafiarem os padrões mínimos de evidência e argumentos aceitos pela sociedade; d) as repetições da opinião alheia (como afirmar que "todos acreditam que a homossexualidade é errada"), já que as convicções morais devem ser concebidas pelo próprio indivíduo, que deve ter suas próprias razões e não apenas repetir as opiniões dos demais (DWORKIN, 1966, p. 996/997).

Se não bastasse, existe um dever de coerência por parte do indivíduo que adota determinada posição moral. Aquele que sustenta com base na Bíblia que a homossexualidade é errada, mas que acredita que outros tipos de atos sexuais não o são (e.g., sexo oral) ou que é correto utilizar métodos anticonceptivos, deverá ser capaz de formular razões que justifiquem a exceção. Do contrário, o indivíduo estaria sendo 
inconsistente ou incoerente com a teoria que toma como base para sustentar suas posições morais (DWORKIN, 1966, p. 997/998).

Dworkin critica a posição de Devlin, portanto, por este se basear em uma "sociologia da moral" falha e incompleta. Se considerarmos que sentimentos como a repulsa não são suficientes para justificar moralmente nossas posições, como pretende Devlin ao tratar da "visão do homem médio", o legislador não poderia se basear em tais sentimentos (generalizados ou não) para limitar liberdades individuais. Assim, não bastaria ao legislador observar o comportamento da sociedade ou simplesmente constatar que, pelo fato da maioria ser contrária ao casamento entre pessoas do mesmo sexo, os homossexuais não têm o direito de se casar. Ao contrário, o legislador deve ser capaz de identificar quais posições são verdadeiramente morais - e não pautadas em preconceitos ou sentimentos pessoais - o que pode ser feito através do debate público e de testemunhos de pessoas interessadas (DWORKIN, 1966, p. 1001).

A crítica dworkiniana à posição de Devlin nos permite concluir que não basta uma "vontade da maioria" para limitar direitos e liberdades individuais. Ao contrário, a ideia de posição moral indica a necessidade de que nossas posições sejam justificadas. Mas não é apenas por tal fato que as preocupações com uma concepção de democracia pautada na vontade da maioria são, em geral, equivocadas: interpretando Mill e Tocqueville, José Reinaldo de Lima Lopes defende que estes autores buscavam o respeito às individualidades e à diversidade como única forma de se respeitar a liberdade em um ambiente que se pretenda democrático:

\footnotetext{
Toca-se aqui um ponto fundamental da própria concepção de democracia e seu funcionamento. Como já foi dito, a preocupação de Mill (como a de Tocqueville) era que a democracia viesse a perder a noção forte de liberdade. O mecanismo da agregação numérica das preferências poderia gerar, temiam eles, a formação de um consenso em torno de médias majoritárias que seriam provavelmente mais medíocres do que medianas. Por essa prática, a tendência que temiam era a de que as individualidades se sufocassem pela força das maiorias medíocres que as calariam. Daí sua defesa das individualidades. Democracias que não respeitassem as atitudes individuais críticas e diferentes tenderiam com o tempo a tornar-se ditaduras das maiorias, estioladas pela falta de pensamento autônomo. A diversidade entre as pessoas deveria ser, portanto, valorizada e respeitada (LOPES, 2007, p. 65).
}

Acredito que é com base nesta ideia de liberdade, marcada pela autonomia individual, que se pode chegar a uma compreensão adequada do papel do Estado diante das questões referentes à relação entre Direito e moralidade pública. Ela fundamenta um dever do Estado de tratar a todos com igualdade de respeito e consideração, o que implica, dentre 
outros, em reconhecer a autonomia dos indivíduos em decidirem o que pretendem buscar em suas próprias vidas. Creio que esta ideia é bem analisada por Ronald Dworkin - e daí sua importância não apenas no debate de cunho meramente conceitual sobre casamento, mas também quando se busca seu reconhecimento como direito moral dos homossexuais, pelas razões a seguir.

\subsection{O DEVER DO ESTADO DE TRATAR A TODOS COM IGUALDADE DE RESPEITO E CONSIDERAÇÃO}

Como sugerido, o reconhecimento do direito moral ao casamento entre pessoas do mesmo sexo envolve considerações acerca do dever do Estado em tratar os cidadãos com igualdade de consideração e respeito. Para compreendermos o que isso significa, devemos em um primeiro momento reconhecer que compartilhamos determinadas visões sobre a importância e as responsabilidades centrais da vida humana (DWORKIN, 2006a, p. 6-7). Nós compartilhamos determinados princípios que tornam os debates de cunho moral inteligíveis, correspondendo àquilo que Dworkin denomina "fundamento comum" (common ground).

$\mathrm{O}$ respeito à dignidade humana corresponde a um paradigma que deve ser observado por todas as pessoas. De uma forma ou de outra, a desconstrução de argumentos morais acaba nos levando em direção a um ideário compartilhado acerca do que compõe esta dignidade. Para Dworkin, ela pode ser fracionada em dois princípios fundamentais. O primeiro corresponderia ao princípio do valor intrínseco, que sustenta que cada vida humana tem um tipo especial de valor objetivo - nós acreditamos que, uma vez que a vida humana tenha começado, é importante a forma com que ela é conduzida (DWORKIN, 2006a, p. 9). O outro princípio diz respeito à responsabilidade pessoal, considerando que cada indivíduo possui uma responsabilidade especial para alcançar o sucesso em sua própria vida, o que inclui o julgamento pessoal de qual tipo de vida é considerado valioso - trata-se de uma responsabilidade soberana do indivíduo sobre aquilo que considera relevante para sua própria vida (DWORKIN, 2006a, p. 10).

Tais princípios se relacionam diretamente com a atuação do Estado e com princípios como a igualdade e a liberdade. Para Dworkin, é dever do Estado tratar cada indivíduo com igual consideração e respeito, sem distinções arbitrárias. Isso significa, dentre outros, que não deverá interferir nas escolhas pessoais dos indivíduos, ditando que tipo de vida seria considerado mais valioso que outro, e que deverá preocupar-se 
igualmente com o destino de todos aqueles sobre os quais pretende exercer domínio (DWORKIN, 2011, p. 2).

Também é necessário reconhecer limitações ao agir estatal. O primeiro diz respeito à distinção entre ética e moral. Enquanto padrões éticos disciplinam como devemos viver nossas vidas particulares, padrões morais prescrevem como devemos tratar as demais pessoas (DWORKIN, 2011, p. 191). Neste sentido, ainda que exista uma responsabilidade pessoal no plano ético, tal plano pertence apenas ao indivíduo e não pode sofrer qualquer espécie de limitação, seja por outras pessoas ou pelo Estado. A escolha de como se viver, de quais objetivos devem ser perseguidos, integra esta dimensão ética da vida humana cuja responsabilidade recai inteiramente sobre o indivíduo em particular - o indivíduo deve agir com auto-respeito, reconhecendo que sua vida é objetivamente valiosa (e que é um erro não se preocupar com a própria vida), e com autenticidade, vivendo de acordo com os valores que, por si só, julga apropriados (DWORKIN, 2011, p. 205; 209/210). O interessante é que todos estes pontos me parecem diretamente relacionados com a ideia de autonomia.

A defesa da autonomia individual é uma constante nos autores que analiso ao longo deste trabalho. Se é possível afirmar que Dworkin a trata enquanto um aspecto da ética (como a responsabilidade pessoal e até mesmo a autenticidade), Finnis a vê como uma das exigências da razoabilidade prática - particularmente a nona exigência, correspondente à importância de se agir de acordo com a própria consciência (FINNIS, 2011b, p. 125). Mas o que me parece relevante destacar neste contexto é, antes de um "dever" de se agir de maneira autonomia, a liberdade que a torna possível.

O que se observa é que a complexidade humana faz com que nossas ações possam se dirigir aos mais diferentes fins - os diversos "bens", de acordo com a interpretação de Grisez acerca da teoria de Tomás de Aquino, como visto no capítulo anterior. Logo, a realização humana pode se operar das mais diversas formas possíveis, de onde resultaria um campo de "liberdade" nas ações individuais. Mas a liberdade não poderia ser compreendida apenas como uma pura e simples escolha dentre diferentes “opções”, já que ela é exercida sempre dentro de um contexto intersubjetivo. Pois qualquer ser humano tem uma necessidade inexorável de viver em comunidade - ou, melhor dizendo, de relacionarse com os demais, algo que seria igualmente evidente e nos leva em direção à ideia de bem comum $^{112}$.

\footnotetext{
${ }^{112}$ Neste sentido se manifesta José Reinaldo de Lima Lopes (2007, p. 44): “Organismos como os nossos - de
} seres humanos - e vidas como as nossas não são completamente autônomos e disjuntivos. Nossos 
Estas observações nos conduzem à autonomia enquanto possibilidade dos indivíduos decidirem quais, dentre os bens possíveis para a realização humana, dedicarão suas vidas. Mas na medida em que esta autonomia é apreendida em um contexto social, ela só se concretiza dentro de um ambiente de "imunidade", de uma verdadeira "liberdade negativa" que gera um dever de não-interferência por parte dos demais indivíduos (LOPES, 2007, p. 46). Não é por outra razão que, se os indivíduos possuem liberdade para definir o que querem ou consideram valioso para suas próprias vidas, a sociedade política não pode, por si, definir um "bem específico" que vá em sentido contrário aos bens individuais. Em sua natureza, como defende José Reinaldo de Lima Lopes, uma sociedade política deve ser open-ended e não pode ter qualquer pretensão de definir os bens a serem buscados pelos indivíduos:

Comunidades políticas são open-ended, não têm um bem determinado ou singular, mas seu bem é sempre universal e geral. Por isso, mesmo na tradição clássica, as comunidades políticas se chamavam comunidades perfeitas, pois compreendiam todas as outras comunidades (com fins mais específicos) e todos os indivíduos (com fins pessoais). (...) Para que uma sociedade de pessoas livres exista e continue a existir, é preciso que ela diga menos a respeito da vida de todos em comum, mesmo que todos pensem diferentemente. Isto implica que a sociedade política (a comunidade das comunidades) não tenha propósitos totalizantes, isto é, pretensões de definir o bem que deve ser buscado individualmente pelos seus membros. Esses bens são deixados à consciência de cada um (LOPES, 2007, p. 48-49).

Se retomarmos a distinção entre ética e moral no pensamento dworkiniano, acredito que tais observações se encaixam perfeitamente: pois se de um lado a autonomia pode ser vista como um aspecto da responsabilidade ética de cada pessoa, de outro ela também se apresenta no âmbito moral e político, gerando deveres por parte do Estado e todos aqueles com quem nos relacionamos ${ }^{113}$.

organismos, isto é, nós mesmos, estamos de alguma forma ligados pelo processo de geração aos que nos antecedem e sucedem, e nossas vidas individuais dependem em parte de nossa sobrevivência também como espécie, pois não parece muito pensável que cada um possa, ou mesmo queira, viver fora de um mundo de outros seres humanos. Podemos até não gostar especialmente dos seres humanos com quem vivemos, ou de alguns em particular. Mas dificilmente gostaríamos do deserto por si mesmo. Também não parece plausível pensar empiricamente na sobrevivência de cada um, visto que foi pela cooperação que a espécie desenvolveu ou adquiriu sua vantagem evolutiva. Não há uma disjuntiva completa entre cada ser humano do ponto de vista puramente empírico natural. Fixemo-nos por um breve momento na dependência recíproca de todos nós, na divisão social do trabalho, na impossibilidade mesma de provermos de uma hora para outra nossa própria sobrevivência, e a ideia de uma vida solta, indiferente e isolada mostra seu grau de absurdo prático".

${ }_{113}$ Parece-me que a questão da autonomia também está diretamente relacionada ao fato de que as diferentes inclinações se manifestam de forma distinta entre diferentes indivíduos. Assim, ainda que todos consigam ver no conhecimento um bem em si mesmo, nem todos possuem a mesma "disposição" para transformá-lo no fim de suas ações individuais - nem todas as pessoas, por exemplo, possuem uma inclinação propensa à ciência ou às abstrações teóricas, da mesma forma com que um cientista pode não ter uma inclinação mais 
Acredito que a distinção estabelecida entre liberty e freedom ${ }^{114}$ explicite claramente a responsabilidade estatal diante da autonomia do indivíduo. Para Dworkin (2006a, p. 67), liberty diz respeito ao conjunto de direitos que o governo estabelece e aplica para proteger a responsabilidade ética pessoal de cada indivíduo. Corresponde, portanto, a áreas da liberdade individual no qual o Estado erra ao limitar ou invadir. Já freedom corresponde àquela área da liberdade individual, definida de forma mais neutra, e que pode ser limitada pelo Estado de forma a prevenir que cada um venha a agir da forma que desejar, gerando danos à terceiros ou à coletividade - assim, o Estado não age errado ao impedir o sequestro de crianças (DWORKIN, 2006a, p. 67).

A liberty pressupõe, portanto, que as pessoas têm um direito de escolher e de viver as suas próprias vidas da forma que considerarem mais valiosas, relacionando-se diretamente com os dois princípios já mencionados da dignidade humana - do valor intrínseco da vida e da responsabilidade ética pessoal. Mas não se trata apenas de viver livremente de acordo com nossos próprios valores: devemos descobrir o que, por direito, nos pertence, uma vez que devemos aceitar que nossa liberty não será afrontada quando o Estado restringe nosso agir em decorrência de razões distributivas plausíveis (DWORKIN, 2006a, p. 69/70). Assim, por exemplo, uma tributação injusta poderia comprometer a liberty, o que não ocorre com a justa tributação.

Se formos capazes de perceber que todas as pessoas possuem uma vida objetivamente valiosa e que cada uma possui responsabilidade ética pessoal, devemos reconhecer que a vida e responsabilidade de cada pessoa tem a mesma importância que a nossa - em última análise, somos capazes de reconhecer que toda pessoa pode ser, assim como nós, dotada de autonomia ${ }^{115}$. Assim, não é possível considerar todas as restrições de cunho distribucional, que alocam recursos entre estas diferentes vidas, como afrontosas à nossa responsabilidade pessoal ética (DWORKIN, 2006a, p. 70).

\footnotetext{
desenvolvida para as artes. De forma análoga se passa com a sexualidade: alguns indivíduos a manifestam relacionando-se com pessoas de sexo distinto (sendo heterossexuais), outras com pessoas do mesmo sexo (as homossexuais) e outras, ainda, sem distinção de gênero (conhecidas como bissexuais). Há até mesmo pessoas assexuais, que simplesmente não possuem uma inclinação à sexualidade - o que não significa dizer que tais pessoas não orientam suas ações com base em outros fins que possam ser considerados igualmente básicos e evidentes, ou que eventualmente não tenham inclinação para relacionamentos afetivos com o desejo de se construir uma vida em comum.

${ }^{114}$ Manterei os termos originalmente utilizados por Dworkin diante da ausência de correlatos na língua portuguesa, e pela importância da distinção. Tanto liberty quanto freedom são traduzidos, indistintamente, como liberdade. Propor uma tradução para tais termos poderia prejudicar a clareza conceitual existente no original em inglês.

115 "Pode ser" porque, como lembra José Reinaldo de Lima Lopes, o que se observa é que na verdade somos "potencialmente aptos" à liberdade e ao exercício da autonomia. Não podemos nos esquecer daqueles que são vistos como "incapazes", aqueles que não conseguem compreender o "jogo social” e não são capazes de "entrar para a vida segundo regras" (LOPES, 2007, p. 50).
} 
Mas ao lado de justificações distributivas que podem eventualmente restringir a liberdade (que neste caso corresponderia à freedom) dos indivíduos, há outros dois tipos de justificativas que podem ser propostas. Uma justificativa baseada em julgamentos pessoais implica na consideração de que determinados tipos de vida são intrinsecamente bons ou ruins. Assim, considerar a homossexualidade errada per se, alegando sua imoralidade, corresponderia a uma justificativa baseada em um julgamento pessoal (DWORKIN, 2006a, p. 70). Por outro lado, há justificativas baseadas em julgamentos impessoais, que se fundamentam no valor intrínseco de determinados objetos ou situações impessoais - é o caso das limitações estatais impostas às madeireiras com vistas à proteção de grandes florestas (DWORKIN, 2006a, p. 71).

$\mathrm{Na}$ medida em que consideramos que cada pessoa possui uma responsabilidade ética e autonomia para dirigir sua própria vida, e que o Estado deve tratar com igual respeito e consideração a vida de todos aqueles que se encontram sob seu domínio, devemos afastar quaisquer tipos de razões baseadas em julgamentos pessoais para justificar que homossexuais não possam se casar. Como se viu, a homossexualidade não é algo "intrinsecamente ruim", mas antes uma forma possível de vivenciar o bem da sexualidade. E mesmo que se apresente um julgamento impessoal, em favor de um valor intrínseco da procriação ou da parentalidade, a homossexualidade não corresponde a uma ofensa a tais valores quando notamos que ela corresponde a uma manifestação natural da própria sexualidade humana. Ademais, parece-me implausível o argumento de que as pessoas "virariam" homossexuais caso tais valores não fossem preservados - até porque se observa que a criação por pais heterossexuais, em um ambiente dito "heteronormativo", não corresponde a uma garantia da heterossexualidade dos indivíduos. Por consequência, o reconhecimento de que todas as vidas são igualmente valiosas, sejam heterossexuais ou não, e que cada pessoa possui uma dimensão de liberdade (liberty) que não pode em hipótese alguma ser limitada pelo Estado implica no reconhecimento de que há um direito moral ao casamento homossexual. Afinal, o casamento é também uma realidade histórica que, como se observou, não comporta a criação de uma "alternativa" capaz de carregar a mesma intensidade de significado que tal conceito traduz (DWORKIN, 2006a, p. 86).

Como sustentei anteriormente, não se trata de uma mera questão linguística ou terminológica, mas sim de se reconhecer que o casamento envolve valores que dizem respeito à existência de uma relação afetiva específica entre duas pessoas, existência esta que se "materializa institucionalmente" através do casamento. Logo, em momento algum discordei que a união entre homem e mulher seja importante e que mereça atenção por 
parte do Direito. O que afirmei ao longo do trabalho é que não existe razão plausível para considerar que a união entre duas mulheres ou entre dois homens não mereça a mesma atenção - ao contrário, o que se percebe é que ambos os tipos de relacionamento se submetem às mesmas necessidades e contingências do destino, como afirmado no capítulo anterior. Ressalte-se sempre que heterossexualidade e homossexualidade correspondem a formas de se manifestar a sexualidade, sendo esta uma inclinação evidente e necessária para a realização pessoal dos indivíduos enquanto seres humanos. Todos somos, em última instância, capazes de amar; e esta capacidade se traduz em relações pautadas pela criação de objetivos em comum, pela geração de expectativas recíprocas e pela troca mútua de afeto e carinho.

Desta constatação se segue que tanto a vida de heterossexuais quanto de lésbicas, gays e outras minorias sexuais deve ser vista como igualmente valiosa. Inexistem razões plausíveis para estabelecer qualquer espécie de diferenciação. Segue-se que, se o Estado deve tratar com igual respeito e consideração a vida de todo e qualquer cidadão, deve reconhecer a existência de um direito moral ao casamento entre pessoas do mesmo sexo.

\subsection{A RELEVÂNCIA DO PENSAMENTO CONCEITUAL E MORAL PARA A TOMADA DE DECISÃO}

Todas as questões levantadas ao longo deste trabalho demonstram que, ainda que para uma grande parte das pessoas a possibilidade do casamento entre pessoas do mesmo sexo corresponda a uma obviedade, a existência de posições divergentes implica na necessidade de apresentarmos justificações para nossas posições. Da mesma forma, e acredito que com maior razão, os que são contrários ao casamento homossexual também são instados a justificarem suas convicções. Isso ocorre porque, como visto, atribuímos ao casamento não apenas uma série de valores, mas também de direitos. Ao restringirmos o matrimônio a uma classe de indivíduos, impedimos que outras pessoas sejam capazes de acessarem os direitos que de outra forma lhes restariam impossibilitados.

A necessidade de justificação exerce, a meu ver, uma função que chega a ser intrínseca ao conceito de Direito. Como Ronaldo Porto Macedo Jr. lembra em muitas de suas aulas, nós não somos capazes de conceber o próprio propósito do sistema jurídico fora da justificação - nós somos incapazes de conceber como Direito um sistema onde a 
atribuição de penas ou recompensas para determinadas condutas se dê por sorteio, de forma análoga a um jogo de bingo.

Esta é uma realidade que não passa despercebida pelos autores tratados ao longo deste trabalho. Se retomarmos o artigo Modelo de Regras I, onde Dworkin elabora sua crítica seminal ao positivismo jurídico, percebe-se que seu ponto de partida reside justamente no potencial que teorias jurídicas têm em explicar o sentido dos conceitos que, diuturnamente, nos valemos para justificar as ações que se relacionam diretamente com a liberdade individual (entendida aqui no seu sentido mais amplo, de conduzir-se como entender conveniente, de fazer ou não fazer) em um contexto de coletividade. Assim, nós devemos compreender o que significam os conceitos que justificam, por exemplo, o uso da força quando encaminhamos alguém para a prisão, tiramos seu dinheiro ou a obrigamos a fazer algo que não gostaria de fazer (DWORKIN, 2010, p. 24).

As perplexidades quanto ao sentido que atribuímos a determinados conceitos jurídicos, ou mesmo morais, está justamente no fato de que tais conceitos integram este campo de justificação. Como afirmei no segundo capítulo, nós não apreendemos o significado de tais conceitos de forma criterial - nossas concepções devem ser interpretativas, pois o contexto prático no qual as apresentamos implica na necessidade de argumentação. Mas não apenas nosso agir moral e jurídico é justificado através destes conceitos, como nossas próprias concepções sobre o que significam tais conceitos também devem ser defendidas de forma justificada. Logo, estas são questões fundamentais que devem ser enfrentadas por todos aqueles que lidam diretamente com o Direito:

\footnotetext{
Estas não são perplexidades para ficarem guardadas no armário e serem trazidas de volta em um dia chuvoso, para diversão. Elas nos causam embaraço quando lidamos com problemas específicos que precisamos resolver de uma maneira ou de outra. Suponhamos que um caso inusitado de direito à privacidade chegue ao tribunal e que o autor da ação não invoque nenhuma lei ou jurisprudência. Que papel deveria desempenhar na decisão do tribunal o fato de que a maioria das pessoas da comunidade pense que cada indivíduo tem uma prerrogativa "moral" a essa privacidade particular? Suponhamos que a Suprema Corte ordene a libertação de um prisioneiro porque a polícia utilizou métodos que a partir de agora a corte declara proibidos constitucionalmente, embora em suas decisões anteriores tenha aceito esses procedimentos. Deve a corte, para ser consistente, libertar todos os prisioneiros anteriormente condenados com base nos mesmos procedimentos? Perplexidades conceituais sobre "o direito" e a "obrigação jurídica" tornam-se agudas quando um tribunal é confrontado com um problema como esse (DWORKIN, 2010, p. 24).
}

Não é por outra razão que juízes devem fundamentar suas decisões. Mas de que maneira um trabalho como este pode contribuir para formar a convicção de magistrados? 
De que forma argumentos como os que levantei, em favor do casamento homossexual, poderiam ser incorporados em uma sentença ou um acórdão?

Pode-se afirmar que, atualmente, a Resolução nº 175 do Conselho Nacional de Justiça (CNJ), de 14 de maio de 2013, "legalizou" o casamento entre pessoas do mesmo sexo no Brasil. Esta resolução impossibilita a recusa, por parte de cartórios em todo o território nacional, de celebrar o casamento civil entre pessoas de mesmo sexo ou de converter em casamento a união estável homoafetiva. A recusa implicará na possibilidade de se recorrer ao juiz corregedor da comarca, que determinará o cumprimento da medida, bem como em eventual responsabilização administrativa do oficial que se negou a celebrar ou converter a união estável em casamento.

Esta medida ainda encontra certa resistência por parte de alguns operadores do Direito, sejam cartorários, promotores ou juízes ${ }^{116}$. Mas o ponto não é apenas que repousam dúvidas quanto ao casamento constituir um direito legal ou jurídico em sentido estrito $^{117}$ dos homossexuais. O mais relevante, a meu ver, seja o reconhecimento de que o casamento corresponda a um direito moral.

Quanto este trabalho se propôs a analisar o conceito de casamento, debatendo diferentes concepções, o que se observou é que o matrimônio não se traduz apenas em direitos e deveres, mas é também a concretização de valores e ideais. Casar-se, como se viu, implica em "institucionalizar" uma relação, fazendo com que seja merecedora de tutela jurídica. $\mathrm{O}$ amor e o afeto não são jurídicos em si, mas as relações deles oriundas podem gerar uma série de planos em comum e expectativas que são merecedores de proteção por parte do Direito - em última análise, o casamento atribui um status ao indivíduo. É por tal razão que, diferentemente de uma simples amizade, o casamento gera obrigações que extrapolam o campo moral. Logo, notadamente quando se pretende negar o direito ao casamento para uma classe de indivíduos, o que se espera não é apenas a aplicação de regras jurídicas por mera subsunção. Deve-se demonstrar o que casais homossexuais têm de diferente dos casais heterossexuais que os impeçam de se casar. Em

\footnotetext{
116 É emblemática a posição do promotor Henrique Limongi, que tem causado polêmica ao negar a habilitação de casamento a vários casais de homossexuais em Santa Catarina. Em suas decisões, além de rejeitar a obrigatoriedade da resolução do CNJ e afirmar que a Constituição Federal é peremptória em dispor que a união estável só pode ocorrer entre homem e mulher, também sustenta que relacionamentos gays fogem ao padrão de normalidade. É o que consta em notícia do dia 23 de agosto de 2013 do Diário Catarinense: $\quad<$ http://diariocatarinense.clicrbs.com.br/sc/geral/noticia/2013/08/promotor-e-contrario-arecomendacao-da-corregedoria-geral-de-sc-e-tem-conduta-questionada-em-florianopolis-4244833.html>. Acesso em 28 de agosto de 2013.

${ }^{117}$ Como mencionei na introdução deste trabalho, para Dworkin os direitos legais ou jurídicos em sentido estrito são aqueles que, em geral criados por um corpo legislativo, podem ser executados pelos indivíduos através de instituições adjudicantes como os tribunais (DWORKIN, 2011, p. 331).
} 
última análise, o casamento é um direito moral porque esta espécie de direito versa justamente sobre interesses particularmente relevantes (como a liberdade e a autonomia), que devem ser protegidos mesmo diante de políticas que busquem tornar as pessoas melhores como um todo - em analogia aos direitos políticos defendidos pela teoria dworkiniana, vistos como "trunfos" diante da atuação estatal (DWORKIN, 2011, p. 329).

É por tal razão que julguei particularmente desinteressante elaborar um trabalho que caísse no "senso comum", a meu ver típico no Brasil, da análise meramente jurídica da questão referente ao casamento homossexual - tomando como certa a igualdade entre homossexuais e heterossexuais. Em suas conclusões, tais análises não estão incorretas, mas não deixam de serem formas incompletas de se avaliar a questão. Pois autores como Finnis, ainda que a meu ver estejam redondamente enganados, se preocuparam em formular uma justificativa de natureza moral para não estender o matrimônio a casais do mesmo sexo. Eles não justificam sua posição no texto legislativo; antes disso, apresentam argumentos que, em seus pontos de vista, justificam o fato da lei, eventualmente, ser como ela é. O esforço que empreendem em demonstrar porque, conceitualmente, lésbicas e gays não teriam direito ao casamento são merecedores de atenção e crítica ${ }^{118}$. E não é possível criticar de forma satisfatória suas convicções afirmando que o Direito deve tratar todos igualmente, uma vez que o que está em questão é o conceito de casamento e suas implicações na vida de todo e qualquer indivíduo.

É deste modo que o trabalho se mostra relevante para a tarefa judicante. O argumento aqui apresentado versa especificamente sobre o casamento, mas sua forma se estende para qualquer outra questão que eventualmente verse sobre direitos morais, como me parece ser o caso do aborto ou da eutanásia. Isso não significa que um juiz deva exaurir todos os argumentos possíveis em suas fundamentações, alcançando o nível de abstração teórica presente em alguns momentos deste trabalho; pode-se afirmar que tais argumentos e abstrações, ainda assim, se encontram implícitos nas fundamentações judiciais ${ }^{119}$. Mas a

\footnotetext{
118 Nunca é demais relembrar a posição de Andrew Koppelman (2004, p. 22): “Only NNL [New Natural Law] theorists, among defenders of traditional views about the morality of homosexuality, justify those views without invoking false factual claims about gay people. Intellectually candid, they recognize that the task is to identify something of value in the sexuality of married, infertile heterosexual couples that is absent from homosexual relations. A fair assessment of NNL is important, because it may be the last respectable stronghold of the beliefs that homosexual conduct is intrinsically wrong and that marriage is necessarily heterosexual".

119 Ronaldo Porto Macedo Jr., em suas aulas, explicita este ponto com uma analogia interessante. Um engenheiro pode se valer da física newtoniana para resolver satisfatoriamente uma série de implicações da construção de uma ponte, sem necessidade de recorrer à física quântica. De maneira semelhante, um juiz é capaz de justificar satisfatoriamente suas convicções sem necessidade de formular expressamente todos os argumentos possíveis.
} 
tarefa de justificação torna-se muito mais importante quando o que se busca é a negação direitos.

Um exemplo emblemático desta questão me parece presente no voto do Ministro Ricardo Lewandowski nas mencionadas ADPF 132 e ADI 4.277 ${ }^{120}$, nas quais o Supremo Tribunal Federal reconheceu às uniões entre pessoas do mesmo sexo o caráter de uniões civis análogas às uniões estáveis de casais heterossexuais - sendo vistas, portanto, como entidades familiares. Ao final de seu voto, onde ressalta que a união homoafetiva deve ser vista como uma espécie familiar distinta do casamento, da união estável ou das relações entre pais e seus descendentes, Lewandowski afirma:

\begin{abstract}
Em suma, reconhecida a união homoafetiva como entidade familiar aplicam-se a ela as regras do instituto que lhe é mais próximo, qual seja, a união estável heterossexual, mas apenas nos aspectos em que são assemelhados, descartandose aqueles que são próprios da relação entre pessoas de sexo distinto, segundo a vetusta máxima ubi eadem ratio ibi idem jus, que fundamenta o emprego da analogia no âmbito jurídico. Isso posto, pelo meu voto, julgo procedentes as presentes ações diretas de inconstitucionalidade para que sejam aplicadas às uniões homoafetivas, caracterizadas como entidades familiares, as prescrições legais relativas às uniões estáveis heterossexuais, excluídas aquelas que exijam a diversidade de sexo para o seu exercício, até que sobrevenham disposições normativas específicas que regulem tais relações.
\end{abstract}

Assim, o Ministro Lewandowski estabelece "restrições" à união homoafetiva, pois a aplicação analógica do regramento pertinente à união estável heterossexual deve ocorrer apenas nos aspectos em que são assemelhadas, "descartando-se aqueles que são próprios da relação entre pessoas de sexo distinto". Mas quais seriam os aspectos próprios da relação entre casais heterossexuais que não deveriam ser levadas em consideração pelo Direito quando se trata de uniões homoafetivas? Quais prescrições legais, no que diz respeito às relações familiares, exigem a diversidade de sexo para o seu exercício?

A pretensão de Lewandowski, ao que me parece, era excluir a possibilidade de uniões homoafetivas serem convertidas em casamento, considerando que esta seria uma prerrogativa das uniões estáveis heterossexuais, como se observa no $\S 3^{\circ}$ do art. 226 da Constituição Federal. Para o Ministro, a intenção do constituinte originário sempre foi clara no sentido de excluir uniões entre pessoas do mesmo sexo do âmbito da união estável. Mas o que o Lewandowski não foi capaz de atentar é que, independentemente desta ser ou não a intenção do legislador, o reconhecimento estatal de diferentes relações afetivas envolve direitos morais, como as já mencionadas liberdade e autonomia

${ }^{120}$ Voto disponível no site: 〈http://s.conjur.com.br/dl/voto-ricardo-lewandowski-uniao.pdf〉. Acesso em 28 ago. 2013. 
individuais de se decidir o que é valioso para a própria vida. O voto do Ministro é, neste aspecto, um voto pobre e incompleto, pois acaba subsumindo direitos morais à vontade do legislador sem maiores justificações, que no caso se faziam necessárias. Ele não poderia simplesmente prescindir da exposição sobre quais seriam, em seu entender, os "aspectos próprios" da relação heterossexual e sua relevância para a questão, pois um dos fundamentos da demanda foi justamente a afirmação da igualdade entre uniões homossexuais e heterossexuais, o que vai muito além dos textos legais e perquirições sobre a intenção legislativa.

Tal linha de raciocínio demonstra que os argumentos aqui apresentados, em última análise, não são relevantes apenas no momento de aplicação do Direito, atividade exercida em especial pelos magistrados, mas também, e talvez prioritariamente, para todos aqueles que são responsáveis por sua criação. Desse modo, o debate de natureza conceitual sobre o casamento, envolvendo valores e a moralidade pública, é de especial importância para todos aqueles que têm por função legislar. Aqui se insere o mencionado dever do legislador em levar em conta posições morais, coerentemente justificadas, excluindo preconceitos e sentimentos pessoais (DWORKIN, 1966, p. 1001).

Percebe-se, portanto, a relevância que argumentos de ordem conceitual e moral assumem quando se está diante do reconhecimento ou da negação de direitos. Destrinchar os conceitos que utilizamos em nossa vida diária é uma atividade muitas vezes difícil, posto que teórica, mas necessária quando pretendemos justificar de forma coerente e adequada as decisões que interferem direta e indiretamente na vida das pessoas. É por essa razão que legisladores, juízes e operadores do Direito em geral devem, em inúmeras circunstâncias, justificar suas convicções através de razões que vão muito além do raciocínio meramente jurídico - e o casamento entre pessoas do mesmo sexo corresponde a um claro exemplo. 


\section{CONCLUSÕES}

Minha intenção ao longo deste trabalho foi apresentar argumentos em favor do casamento como um direito de lésbicas e gays, e acabei apresentando razões que favorecem não apenas homossexuais, mas outras "minorias sexuais", como é o caso dos transexuais. De qualquer modo, o "direito ao casamento" que aqui defendi não é apenas um direito jurídico ou legal, mas também um direito moral. Isso explica o fato de que meus esforços não tenham se dirigido para a análise da legislação existente, seja ela constitucional ou infraconstitucional, como faz a maior parte dos trabalhos sobre o tema. A metodologia que adotei implica na consideração de que o direito ao casamento é, sobretudo, uma questão de justiça - o seu reconhecimento é imprescindível para qualquer Estado que, defendendo a liberdade e autonomia individuais, trate todos seus cidadãos com igualdade de respeito e consideração.

Mas o trabalho não poderia permanecer aí. Este dever estatal, de tratar a todos com igual respeito e consideração, não implica no reconhecimento automático do direito ao casamento para homossexuais. Isso porque posições contrárias, como é o caso da adotada por alguns jusnaturalistas, exclui conceitualmente os homossexuais do casamento. Em outras palavras, autores influentes como John Finnis se valem de uma concepção de matrimônio que torna irracional o pleito formulado pela comunidade LGBT, uma vez que seu sentido contemplaria apenas a união entre um homem e uma mulher. Logo, o Estado não trataria desigualmente os homossexuais quando reserva o casamento apenas para indivíduos heterossexuais.

Diante de concepções como esta, uma possível forma de assegurar direitos às lésbicas e gays se daria através da criação de uma "união civill", análoga ao casamento para heterossexuais, mas que com ele não se confundiria. O problema é que esta não é uma solução satisfatória, já que homossexuais não lutam apenas pelos direitos de ordem material do casamento, mas também pelos valores que ele simboliza. Este fato sugere que a questão não é meramente taxonômica. Mas ainda é necessário demonstrar a insuficiência desta resposta, o que também envolve descobrir quais os valores associados ao casamento e o que eles significam na vida das pessoas.

Dizer que o casamento se relaciona diretamente com um ou mais valores (que tem, portanto, um point valorativo) implica em concebê-lo interpretativamente, como sugere Ronald Dworkin. Na medida em que tenho a convicção de que homossexuais tem direito 
ao casamento, preciso sustentar que o valor do matrimônio não é exclusividade de casais heterossexuais. Isso implica em demonstrar as razões pelas quais as concepções que sustentam que o casamento só envolve um homem e uma mulher estão equivocadas.

A concepção que escolhi para estabelecer tal interlocução crítica é a apresentada por John Finnis. Ela se pretende livre de quaisquer preconceitos ou crenças religiosas, apresentando de forma analítica não apenas as razões pelas quais o casamento só pode ocorrer entre homem e mulher, mas também o que torna imorais os atos sexuais fora do matrimônio (incluídos, portanto, os atos homossexuais). No primeiro capítulo apresentei esta concepção - ressaltando que o casamento é, para Finnis, um bem humano básico, o que implica na sua consideração como um fim racional da ação humana, autoevidente, inderivado, indemonstrável e incomensurável. Ele tem um "point duplo": a amizade entre os cônjuges e a prática de atos de tipo reprodutivo (a união biológica), que juntos correspondem ao bem do casamento. É particularmente através da ideia de união biológica que Finnis exclui homossexuais do direito ao casamento, tornando seus atos imorais por ofenderem o bem básico do casamento. O mesmo se passaria com todas aquelas relações sexuais que não correspondessem à união biológica, que por sua vez dizem respeito àquela união entre homem e mulher que, enquanto conduta, é a que se espera para a procriação. Analisei também algumas implicações desta concepção em situações como o divórcio, o uso de métodos anticonceptivos e o caso de intersexuais e transexuais.

Posteriormente, no segundo capítulo, sustentei que a forma mais adequada para se compreender o casamento é tratando-o de maneira interpretativa. Para tanto, faço uso do modelo teórico apresentado por Ronald Dworkin. Demonstrei a diferença entre conceito e concepção e as diferentes maneiras pelas quais podemos tratar um conceito (criterial, de tipo natural ou interpretativa). Também defendi a possibilidade de objetividade em questões morais controversas (o que se dá através da coerência e adequação de nossas convicções aos paradigmas socialmente compartilhados) e apresentei as razões que fazem com que o sentido do matrimônio só possa ser alcançado interpretativamente, uma vez que ele diz respeito a valores. Aqui ficam claras as razões pelas quais não se deve tratar a questão do casamento homossexual de forma semântica ou taxonômica. Além do fato de lésbicas e gays lutarem especificamente pelo casamento, a criação de uma união civil para homossexuais e a garantia do casamento apenas para heterossexuais, implicando na existência de dois institutos materialmente e juridicamente equivalentes, pressupõe a existência de razões morais que permaneçam tornando a distinção relevante - e como sustenta Dworkin, estas também seriam razões porque a união civil homossexual não 
deveria ser uma oportunidade equivalente ao casamento (DWORKIN, 2006a, p. 87). Também tratei das distinções entre Dworkin e Finnis na forma com que concebem o valor, asseverando a superioridade da posição dworkiniana por ser capaz de tratar de controvérsias sobre o conceito de casamento, algo que a concepção finnisiana não permite - assumindo uma posição "essencialista". Por fim, ressaltei que Dworkin advoga a existência de alguns valores que seriam intrinsecamente valiosos, o que se aproxima da ideia de bens humanos básicos, mas com ela não se confunde.

No terceiro capítulo, foquei-me, em primeiro lugar, na crítica à concepção finnisiana de casamento. Apresentei por primeiro as críticas já formuladas por Andrew Koppelman e Stephen Macedo que, a meu ver, são inócuas em razão do casamento constituir, para Finnis, um bem humano básico autoevidente. Tais críticas ainda assim são relevantes, pois demonstram que Finnis acaba "blindando" sua concepção de casamento de críticas externas, na medida em que reitera continuamente que o bem do casamento é autoevidente, indemonstrado e indemonstrável - o que pressupõe que seus críticos simplesmente não foram capazes de "experienciar" seu valor intrínseco. Sustentei que a forma de se lidar com uma posição como esta é, justamente, ressaltando a má interpretação que Finnis faz da experiência sexual humana. A partir da interpretação proposta por Germain Grisez sobre o primeiro princípio da razão prática, de raízes aquinianas, defendi que toda ação humana tem um fim, consubstanciado em um bem. Este bem está em direta relação com as inclinações básicas de todo e qualquer indivíduo, pois não faz sentido esperar que alguém se comporte de forma distinta de suas próprias inclinações. Sendo a sexualidade e sua manifestação inclinações básicas do homem, é ela, e não o casamento, que deve ser vista como um bem básico. Ocorre que algumas pessoas se inclinam em direção às relações sexuais e amorosas com pessoas de sexo diferente do seu, enquanto outras se inclinam em direção às pessoas do mesmo sexo. Trata-se de algo revelado pela própria experiência, de modo que o erro de Finnis assemelha-se a um erro factual - ele foi incapaz de notar que a complexidade sexual humana vai muito além da união biológica. Se não bastasse, a parentalidade (maternidade e paternidade) também é uma inclinação humana que não se confunde com a ideia de casamento. Logo, não faz sentido limitar o casamento à união entre um homem e uma mulher, até porque é a experiência que revela a existência de bens mais básicos a compor o matrimônio. Este, em consequência, é derivado e não é autoevidente. Em última análise, o casamento é uma instituição que pode compreender valores básicos. 
$\mathrm{Na}$ segunda parte do terceiro capítulo formulei uma concepção distinta de casamento. O primeiro passo foi, acompanhando as observações de John Searle, ressaltar a característica institucional do matrimônio. Ele corresponde a uma instituição na medida em que é capaz de gerar fatos institucionais, pressupondo uma intencionalidade coletiva na atribuição de funções de status. O casamento dá ao indivíduo um status que gera poderes deônticos (direitos, deveres, obrigações etc.), ao mesmo tempo em que motiva a busca por tais poderes - criando, portanto, novas razões para a ação. Se o casamento gera direitos, sendo um meio para se proteger as expectativas mutuamente formadas por uma relação de caráter afetivo, é natural que as pessoas busquem se casar com quem pretendam criar um plano de vida em comum. Mas o que leva as pessoas a buscarem a construção de vidas comuns é uma inclinação ao afeto e à solidariedade. Trata-se tanto de valores intrínsecos quanto de inclinações que a experiência demonstra serem naturais nos indivíduos: em determinados momentos de nossas vidas, nos apaixonamos e desejamos alguém ao nosso lado, para convivermos em clima de solidariedade, e tal desejo pode se manifestar em todas as pessoas - independentemente da orientação sexual. Isso implica dizer que, conceitualmente, não há razões para se excluir homossexuais do direito ao casamento. Mais que isso, ressalta que o casamento tem um point valorativo, um sentido moral que não descaracteriza seu caráter institucional. Este sentido deve ser buscado de maneira interpretativa, pois o valor do casamento não é autônomo, e sim integrado a outros valores que consideramos relevantes em nossas vidas (demonstrando a relevância de Dworkin para o esclarecimento destas questões). Pode-se, entretanto, asseverar que tal concepção de casamento é demasiadamente abstrata, levantando dúvidas sobre questões como poligamia ou incesto. Tais questões possuem peculiaridades que extrapolam o âmbito deste trabalho, mas sustentei que a metodologia para tratá-las é muito semelhante à que adotei para o caso dos homossexuais. Em qualquer caso, é necessário apresentar razões para justificar o reconhecimento ou a exclusão de algumas espécies de relações do direito ao casamento.

Por fim, o quarto e último capítulo trata do reconhecimento do casamento enquanto um direito moral de lésbicas e gays. Defendi, partindo do debate ocorrido entre Devlin, Hart e Dworkin, que o reconhecimento de direitos independe da vontade da maioria e deve ter por base posições morais coerentes, que não correspondam a meros preconceitos ou sentimentos pessoais. O reconhecimento de direitos transforma-se em um dever do Estado que, buscando tratar os cidadãos com igual respeito e consideração, percebe que sua garantia é imprescindível para a plena manifestação da liberdade e autonomia individuais. Reconhecer o casamento como um direito dos homossexuais não se refere, portanto, 
apenas a uma questão de ordem legislativa, mas à constatação de que tal reconhecimento corresponde a uma questão de justiça - o casamento é também um direito moral, relevante na medida em que se relaciona com valores que entendemos importantes na busca para uma vida plena e feliz. É por esta perspectiva que a análise conceitual do casamento reaparece neste último capítulo do trabalho, pois se casar ou não é algo que altera substancialmente a vida dos indivíduos, é importante que juízes e legisladores apresentem justificativas que vão além do mero legalismo dogmático quando pretenderem reconhecer ou não direitos de natureza moral.

Como mencionei, meus esforços estiveram focados na análise conceitual do casamento, considerando que esta é uma perspectiva muitas vezes esquecida por aqueles que buscam o reconhecimento deste direito às minorias sexuais. Fugi da perspectiva dogmática que, ainda que seja relevante, é incompleta sem uma análise de tipo conceitual, com aportes na Filosofia Moral e Política. De qualquer modo, o mais importante é perceber que lésbicas e gays são pessoas que, como qualquer outra, compartilham desejos e são capazes de amar, com todas as dificuldades, aflições, alegrias e prazeres que relações de cunho sexual e afetivo possam propiciar.

As lutas promovidas por homossexuais podem parecer banais, como sugere o tratamento semântico ou taxonômico para a questão do casamento entre pessoas do mesmo sexo. Mas aqueles que advogam este tratamento se esquecem do valor que o matrimônio compreende, daquilo que ele simboliza de mais importante: a nossa capacidade de estabelecer laços afetivos, pautados na confiança mútua e na solidariedade. Aqueles que fazem parte de uma maioria muitas vezes são incapazes de imaginar as agruras que o estigma social da homossexualidade proporciona, a dor causada pela repressão de atos simples como andar de mãos dadas na rua ou qualquer outra manifestação pública de afeto e carinho. Por desconhecerem esta realidade, muitos acham que tudo não passa de futilidade; mas estes muitos só pensam assim porque tratam de forma leviana sua própria realidade e seus valores, ao casarem e descasarem da mesma forma com que trocam de roupa. É por tais razões que reconhecer o direito ao casamento entre pessoas do mesmo sexo é um dever de todos aqueles que buscam tratar as pessoas igualmente, com respeito e consideração por quem os indivíduos efetivamente são. 


\section{BIBLIOGRAFIA}

BOSWELL, John. Christianity, social tolerance and homosexuality: gay people in western Europe from the beginning of the christian era to the fourteenth century. Chicago: The University of Chigado Press, 1981.

CHAUNCEY JR., George; DUBERMAN, Martin; VICINUS, Martha (ed). Hidden from history: reclaiming the gay and lesbian past. Londres: Penguin, 1991.

Why marriage? The history shaping today's debate over gay equality. EBook - Kindle version. New York: Basic Books, 2005.

"What gay studies taught the court": the historian's amicus brief in Lawrence v. Texas em GLQ: A Journal of Lesbian and Gay Studies, vol. 10, nº. 3, pp. 509538, 2004.

CLARK, Randall Baldwin. Platonic love in a Colorado courtroom: Martha Nussbaum, John Finnis, and Plato's Laws in Evans v. Romer. The Yale Journal of Law \& the Humanities, Vol. 12, nº. 1, 2000.

DEVLIN, Patrick. The enforcement of morals. New York: Oxford University Press, 1965.

DIAS, Maria Berenice. Manual de direito das famílias. $5^{\mathrm{a}}$ ed. São Paulo: Revista dos Tribunais, 2009.

DOVER, Kenneth James. A homossexualidade na Grécia antiga. Tradução de Luís Sérgio Krausz. São Paulo: Nova Alexandria, 2007.

DWORKIN, Ronald. Domínio da vida: aborto, eutanásia e liberdades individuais. Tradução por Jefferson Luiz Camargo. 2a ed. São Paulo: WMF Martins Fontes, 2009.

2006a.

Is democracy possible here? New Jersey: Princeton University Press,

. Justice for hedgehogs. Estados Unidos: The Belknap Press of Harvard University Press, 2011. 
University, 2006b.

Justice in robes. Estados Unidos: The Belknap Press of Harvard . Law's empire. Estados Unidos: The Belknap Press of Harvard University Press, 1986.

Levando os direitos a sério. Tradução de Nelson Boeira. $3^{\text {a }}$ ed. São Paulo: WMF Martins Fontes, 2010.

Lord Devlin and the enforcement of morals. The Yale Law Journal, Vol. 75, no. 6, 1966.

Objectivity and truth: you'd better believe it. Philosophy \& Public Affairs, Vol. 25, nº. 2, 1996.

Uma questão de princípio. Tradução de Luís Carlos Borges. $2^{\mathrm{a}}$ ed. São Paulo: Martins Fontes, 2005.

Sovereign virtue: the theory and practice of equality. Estados Unidos: Harvard University Press, 2002.

ESKRIDGE, Willian N., Jr. Equality practice: civil unions and the future of gay rights. New York: Routledge, 2002

The case for same-sex marriage: from sexual liberty to civilized commitment. New York: The Free Press, 1996.

FINNIS, John. Disintegrity. Em Is homosexual conduct wrong? A philosophical exchange. The New Republic, November 15, pp. 12-13, 1993.

Human rights and common good. Collected Essays: vol. III. New York: Oxford University Press, 2011a.

Law, morality, and "sexual orientation" em CORVINO, John (ed). Same sex: debating the ethics, science, and culture of homosexuality. Lanham, New York, London: Rowman and Littlefield (1997). Disponível em: <http://www.princeton.edu/ anscombe/articles/finnisorientation.pdf >. Acesso em: 24 jun. 2011. 
Leopoldo: Editora Unisinos, 2006.

Lei natural e direitos naturais. Tradução de Leila Mendes. São

- Marriage: a basic and exigent good em The Monist 91 (2008).

Disponível em: <http://papers.ssrn.com/sol3/papers.cfm?abstract_id=1392288>. Acesso em: 24 jun. 2011.

Press, $2011 b$.

Natural law and natural rights. $2^{\mathrm{a}}$ ed. New York: Oxford University University Press, 2011c.

Reason in action. Collected Essays: vol. I. New York: Oxford

The good of marriage and the morality of sexual relations: some philosophical and historical observations. Em American Journal of Jurisprudence, $\mathrm{n}^{\circ} .42$, pp. 97-134 (1998). Disponível em: <http://www.princeton.edu/ anscombe/articles/finnismarriage.pdf $>$. Acesso em: 10 jul. 2011.

FOUCAULT, Michel. História da sexualidade. Tradução de Maria Thereza da Costa Albuquerque e J. A. Guilhon Albuquerque. Rio de Janeiro: Edições Graal, 1988.

FRANKE, Katherine M. The domesticated liberty of Lawrence v. Texas. Em Columbia Law Review vol. 104, pp. 1399-1426 (2004). Disponível em: <http://www2.law.columbia.edu/faculty_franke/Franke-WebCopy.pdf $>$. Acesso em: 22 set. 2011.

FRASER, Nancy. Justice interruptus: critical reflections on the "postsocialist" conditions. New York: Routledge, 1997.

FRY, Peter; MACRAE, Edward. O que é homossexualidade. 1 ${ }^{\text {a }}$. ed. São Paulo: Abril Cultural: Brasiliense, 1985.

GALLIE, Walter Bryce. Essentially contested concepts (1956). Disponível em: $<$ http://commonsenseatheism.com/wp-content/uploads/2011/05/Gallie-EssentiallyContested-Concepts.pdf> Acesso em: 20 jun. 2012

GEORGE, Robert P. In defense of natural law. New York: Oxford University Press, 1999. 
Making men moral: civil liberties and public morality. New York:

Oxford University Press, 1993.

Recent criticism of natural law theory em The University of Chicago

Law Review, vol. 55, $\mathrm{n}^{\mathrm{o}}$. 4, pp. 1371-1429 (1988). Disponível em: <http://www.jstor.org/stable/1599791>. Acesso em: 04 set. 2013.

- The clash of orthodoxies: law, religion, and morality in crisis.

Wilmington: Intercollegiate Studies Institute, 2002.

GIRGIS, Sherif. ANDERSON, Ryan T. What is marriage? em Harvard Journal of Law and Public Policy, vol. 34, no. 1, pp. 245-287 (2010). Disponível em: < http://papers.ssrn.com/sol3/papers.cfm?abstract_id=1722155>. Acesso em: 10 jul. 2011 .

; What's sex got to do with it? em GEORGE, Robert P.; ELSHTAIN, Jean Bethke. The meaning of marriage: family, state, market and morals. EBook Kindle version. New York: Scepter Publishers, 2010

GUEST, Stephen. Ronald Dworkin. Tradução de Luís Carlos Borges. Rio de Janeiro: Elsevier, 2010.

GRISEZ, Germain; RYAN, S. J. Peter F. Indissoluble marriage: a reply to Kenneth Himes and James Coriden em Theological Studies 72, pp. 369-415 (2011). Disponível em: <http://www.catholicworldreport.com/Content/Site140/Blog/922RyanGrisez4p_00000000 553.pdf>. Acesso em: 21 ago. 2013.

; FINNIS, John; MAY, William E. Indissolubility, divorce and holy communion em New Blackfriars, v. 75, n. 883, pp. 321-330 (1994). Disponível em: <http://twotlj.org/OW-3GerBish.pdf>. Acesso em: 21 ago. 2013

O primeiro princípio da razão prática. Tradução de José Reinaldo de Lima Lopes. Revista Direito GV 6, v. 3, n. 2, pp. 179-218 (2007). Disponível em: $<$ http://direitogv.fgv.br/publicacoes/revista/artigo/primeiro-principio-razao-praticacomentario-summa-theologiae-1-2-questao->. Acesso em: 21 ago. 2013.

HART, Herbert L. A. Direito, liberdade, moralidade. Tradução de Gerson Pereira dos Santos. Porto Alegre: Sérgio Antonio Fabris, 1987. 
Law, liberty and morality. Stanford: Stanford University Press, 1963.

The concept of law. $2^{\mathrm{a}}$ ed. New York: Oxford University Press, 1994.

KOPPELMAN, Andrew. Is marriage inherently heterosexual? em American Journal of Jurisprudence, vol. 42, $\mathrm{n}^{\circ} .51,1997$

. The decline and fall of the case against same-sex marriage em University of St. Thomas Law Journal, vol. 2, Iss. 1, article 2, 2004.

LAGO, Pablo Antonio. O princípio da solidariedade familiar: importância e eficácia em TEPEDINO, Gustavo; FACHIN, Luiz Edson (org.). Diálogos sobre direito civil. Vol. III. Rio de Janeiro: Renovar, 2012.

LOPES, José Reinaldo de Lima. O direito ao reconhecimento para gays e lésbicas. Em Revista Internacional de Direitos Humanos - SUR, vol. 2, no. 2, pp. 65-95 (2005). Disponível em: <http://bdjur.stj.gov.br/xmlui/handle/2011/22000>. Acesso em 10 jul. 2011.

Liberdade e direitos sexuais - o problema a partir da moral moderna em RIOS, Roger Raupp (org.). Em defesa dos direitos sexuais. Porto Alegre: Livraria do Advogado, 2007.

MACCORMICK, Neil. Natural law reconsidered. Oxford Journal of Legal Studies, Vol. $1, \mathrm{n}^{\circ} .1,1981$.

MACEDO, Stephen. Homosexuality and the conservative mind em Georgetown Law Journal, vol. 84, $n^{\circ} .261,1995$.

Reply to critics em Georgetown Law Journal, vol. 84, nº 329, 1996.

MACEDO JR., Ronaldo Porto. Como levar Ronald Dworkin a sério ou como fotografar um porco-espinho em movimento. Em GUEST, Stephen. Ronald Dworkin. Tradução de Luís Carlos Borges. Rio de Janeiro: Elsevier, 2010.

O método de leitura estrutural. Cadernos de Direito da Fundação Getúlio Vargas - FGV. Vol. 4. N. 2. São Paulo, março de 2007. 
MARTINS, Ives Gandra da Silva. Família é aquela que perpetua a sociedade. Disponível em<http://www.conjur.com.br/2011-mai-12/constituinte-familia-aquela-geradescendendes-sociedade> Acesso em: 25 abr. 2012.

MIELI, Mario. Elementi di critica omosessuale. $2^{\text {a }}$ ed. Milão: Feltrinelli Editore, 2002.

MORAES, Maria Celina Bodin de. O princípio da solidariedade, em MATOS, Ana Carla Harmatiuk (org.). A construção dos novos direitos. Porto Alegre: Núria Fabris, 2008.

NUSSBAUM, Martha. From disgust to humanity: sexual orientation and constitutional law. Estados Unidos: Oxford University Press, 2010.

. Integrity em Is homosexual conduct wrong? A philosophical exchange. The New Republic, November 15, p. 13, 1993.

. Sex \& social justice. New York: Oxford University Press, 1991.

RAWLS, John. Uma teoria da justiça. Tradução de Almiro Pisetta e Lenita Maria Rímoli Esteves. $2^{a}$ ed. São Paulo: Martins Fontes, 2002.

RAZ, Joseph. Razão prática e normas. Tradução de José Garcez Ghirardi. São Paulo: Elsevier, 2010.

SEARLE, John R. Mente, linguagem e sociedade: filosofia no mundo real. Tradução de F. Rangel. Rio de Janeiro: Rocco, 2000.

What is an institution? em Journal of Institutional Economics, vol. 1, $\mathrm{n}^{\mathrm{o}}$. 1 , pp. $1-22$ (2005). Disponível em: $<$ http://www.laisumedu.org/DESIN_Ibarra/desin/pdf-seminario2006/seminario-200604d.pdf>. Acesso em: 05 set. 2013.

STEIN, Edward. Introducing Lawrence v. Texas: background and a glimpse of the future em Cardozo Women's Law Journal, vol. 10, $\mathrm{n}^{\circ} .263$ (2004). Disponível em: http://papers.ssrn.com/sol3/papers.cfm?abstract_id=520543>. Acesso em: 10 jul. 2011.

TAYLOR, Charles. The ethics of authenticity. Estados Unidos: Harvard University Press, 1991. 
VENTURA, Miriam. Transexualidade: algumas reflexões jurídicas sobre a autonomia corporal e autodeterminação da identidade sexual em RIOS, Roger Raupp (org.). Em defesa dos direitos sexuais. Porto Alegre: Livraria do Advogado, 2007.

WACKS, Raymond. Understanding jurisprudence: an introduction to legal theory. New York: Oxford University Press, 2012. 